\title{
Casa própria ou apropriada?
}

duas abordagens: 0 FUNAPS Comunitário e o Projeto Cingapura
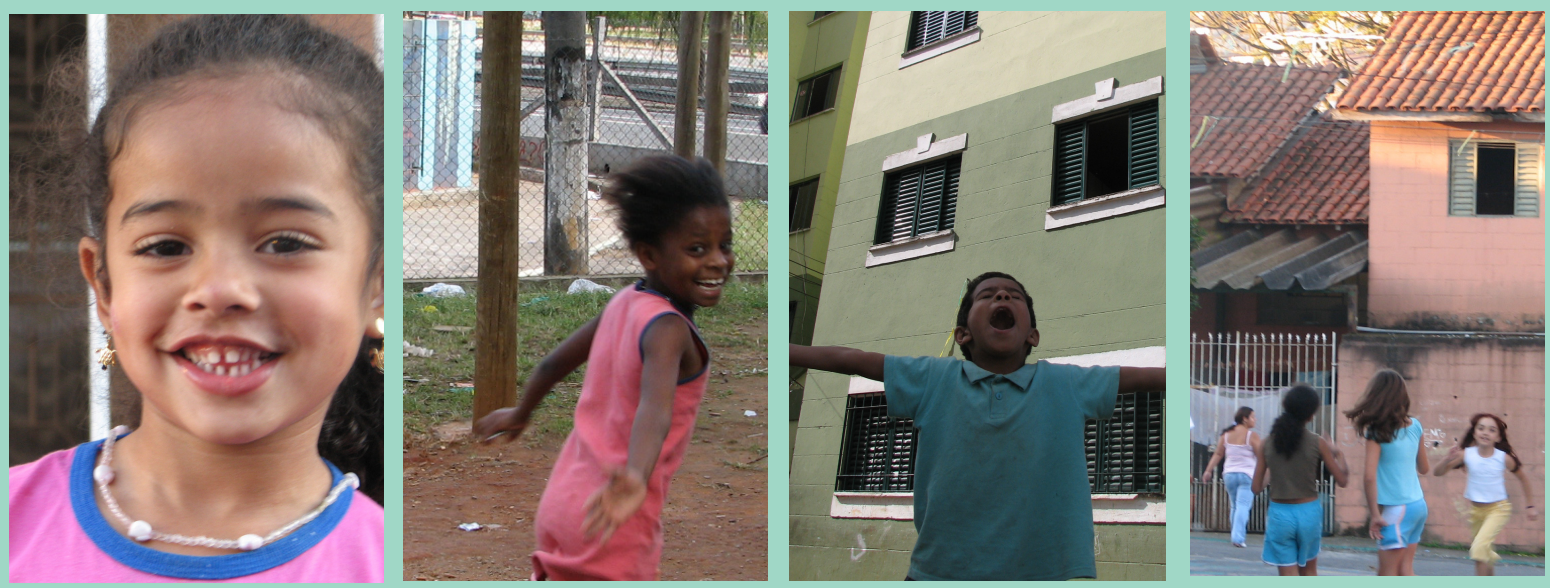

Soraya Rodrigues

São Paulo 


\title{
Soraya Rodrigues
}

\author{
CASA PRÓPRIA OU APROPRIADA? \\ Duas Abordagens: 0 FUNAPS Comunitário e o Projeto Cingapura \\ Dissertação apresentada à Faculdade de Arquitetura \\ e Urbanismo da Universidade de São Paulo. \\ Área de concentração: Tecnologia da Construção \\ Orientador:Prof. Dr. Reginaldo Luiz Nunes Ronconi
}

São Paulo

Agosto de 2006 


\section{Agradecimentos}

Costuma dizer minha mãe que na vida a gente precisa de "muletas". No seu vocabulário goiano muletas são aquelas pessoas que ajudam a gente a caminhar pela vida. Eu, nesse trabalho, contei com muitas muletas, sem as quais eu não teria conseguido andar até aqui. São essas pessoas que eu gostaria agora de agradecer:

Á minha mãe e ao meu pai pelo exemplo de integridade.

Ao Richard pelo amor, pela companhia, por todas as vezes que leu e me orientou nesse trabalho e pelo auxílio prestado em satisfazer os caprichos desse computador.

Ao Toti, por sua alegria e doçura que torna tudo mais leve.

À Janice, ao Fê , à Glauce-néa e à Idelma pelo apoio e proteção incondicionais.

À Camila, por ter emprestado sua competência à legibilidade desse trabalho, e por tudo que a palavra amizade significa.

À Márcia, à Vânia e à Idália, moradoras do Cingapura Imigrantes, pelo apoio que só mulheres fortes como elas sabem dar.

À Izilda, à Nice, à Luciana, ao Francisco e ao Zé Rodrigues, moradores do Campanha Gaúcha, pela recepção, pela paciência e pelo exemplo de perseverança.

À criançada do Cingapura Imigrantes, pela diversão proporcionada em todas as visitas àquele local.

Ao Reginaldo, meu orientador, pela confiança e por ter acreditado no propósito desse trabalho.

Aos professores João Whitaker e Jorge Oseki, pela valiosa colaboração no exame de qualificação, na estrutura e metodologia desse trabalho, respectivamente.

Ao professor Gustavo Neves da Rocha Filho, responsável por parte significativa de minha formação intelectual.

A FAU/USP pelo incentivo dado à produção desse trabalho.

À Melkia e ao Diler, pela transcrição das entrevistas e pela amizade.

Ao Félix por ter suportado, pacientemente, dividir minha atenção com o computador todos esses dias.

E por fim, mas não menos importante, ao Daniel por seu otimismo, pelos conselhos e sugestões preciosas a este trabalho. 


\section{Resumo}

Este trabalho investiga quais as práticas que, no âmbito dos programas públicos de habitação popular, contribuem para a produção de moradias mais adequadas à realidade cultural de seus usuários. Para tanto, aborda dois programas que foram idealizados e implementados de forma completamente distinta, na cidade de São Paulo na década de 90:

- 0 FUNAPS Comunitário: implantado através dos mutirões autogestionários entre os anos 1989 e 1992 ; e

- 0 Projeto Cingapura: implantado através de grandes construtoras entre os anos 1993 e 2000.

A pesquisa foi inteiramente baseada na opinião dos moradores, de dois conjuntos habitacionais, o Conjunto Habitacional Campanha Gaúcha viabilizado pelo FUNAPS Comunitário, e o Conjunto Habitacional Imigrantes, viabilizado pelo Projeto Cingapura.

Os dados obtidos nessa pesquisa subsidiaram algumas conclusões a respeito de que forma os meios utilizados nos processos de acesso à moradia através de programas públicos de habitação estudados, influenciaram na vida de seus moradores nos mais diversos aspectos, sócio-culturais, políticos, econômicos e até mesmo físicos. Sendo esta a principal contribuição que este trabalho procurou trazer.

Palavras-chave: Habitação de Interesse Social, Política Habitacional, FUNAPS Comunitário, Cingapura. 
ABSTRACT

Keywords: Social Housing, Housing Policy, FUNAPS Comunitário, Cingapura. 
Lista de llustrações

Figura 1 Empreendimentos PAR em algumas cidades brasileiras ......................................... 13

Figura 2 Percentual de domicílios atendidos por alguns serviços, por Grandes Regiões ... 19

Figura 3 Mancha Urbana de São Paulo 1930 ....................................................................... 25

Figura 4 Mancha Urbana de São Paulo 1965 ........................................................................ 25

Figura 5 São Paulo: evolução das taxas de mortalidade infantil 1960-1970 ...................... 27

Figura 6 São Paulo: Localização dos Empreendimentos financiados pelo FUNAPS ............ 46

Figura 7 Folheto PMSP sobre mutirões .............................................................................. 51

Figura 8 Liberação de Verbas por SEHAB e COHAB 1990-2001 …....................................... 52

Figura 9 Mosaico Cingapura ............................................................................................. 56

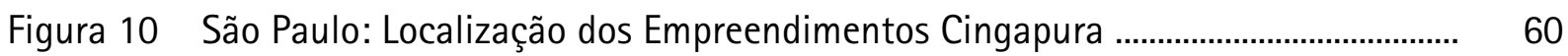

Figura 11 Localização do Conjunto Habitacional Campanha Gaúcha ..................................... 64

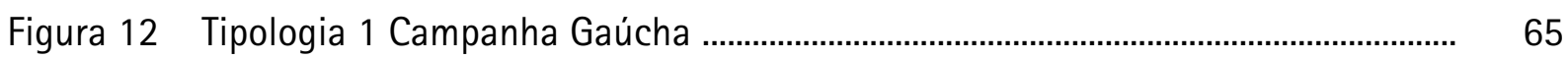

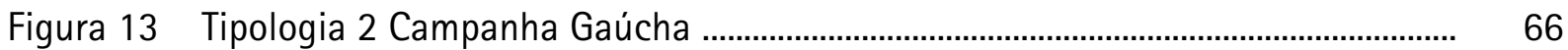

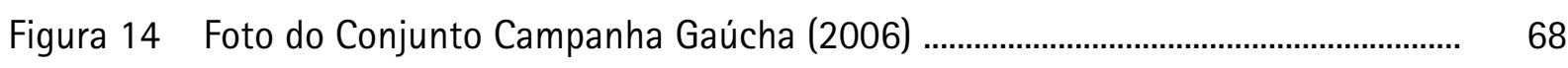

Figura 15 Foto do Conjunto Campanha Gaúcha (2006) .......................................................... 68

Figura 16 Foto interna de casa do Conjunto Campanha Gaúcha (2006) ................................. 68

Figura 17 Foto interna de casa do Conjunto Campanha Gaúcha (2006) ................................ 68

Figura 18 Foto interna de casa do Conjunto Campanha Gaúcha (2006) ................................. 68

Figura 19 Ocupação dos Recuos no Conjunto Campanha Gaúcha ........................................ 69

Figura 20 Ocupação dos Recuos no Conjunto Campanha Gaúcha ......................................... 69

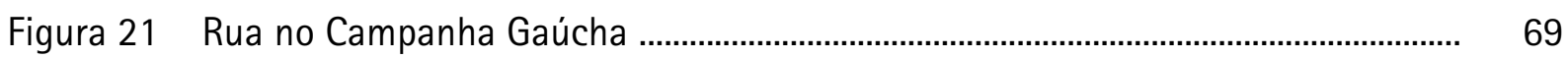

Figura 22 Área Verde no Campanha Gaúcha .......................................................................... 69

Figura 23 Vista geral de rua do Campanha Gaúcha .................................................................. 70

Figura 24 Vista geral de rua do Campanha Gaúcha ............................................................... 70

Figura 25 Vegetação dentro de lote do Campanha Gaúcha ........................................................ 70

Figura 26 Vegetação dentro de lote do Campanha Gaúcha ......................................................... 70

Figura 27 Vegetação dentro de lote do Campanha Gaúcha ....................................................... 70

Figura 28 Localização do Conjunto Habitacional Imigrantes ................................................... 71

Figura 29 Tipologia Cingapura Imigrantes …….................................................................... 72

Figura 30 Visão Geral do Conjunto Cingapura Imigrantes ...................................................... 73

Figura 31 Área de Lazer no Cingapura Imigrantes (2006) ....................................................... 74

Figura 32 Área de Lazer no Cingapura Imigrantes (2006) ....................................................

Figura 33 Entrada de bloco no Imigrantes ...........................................................................

Figura 34 Lixeiras no Imigrantes ........................................................................................ 74

Figura 35 Centro Comunitário do Cingapura Imigrantes .......................................................... 75

Figura 36 Centro Comunitário do Cingapura Imigrantes ....................................................... 75

Figura 37 Rua interna do Cingapura Imigrantes ................................................................... 75

Figura 38 Rua interna do Cingapura Imigrantes ...................................................................... 75

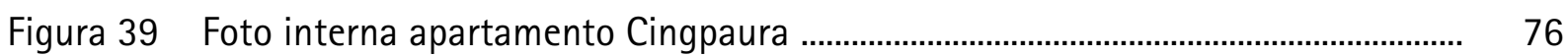


Figura 40 Foto interna apartamento Cingpaura .................................................................... 76

Figura 41 Favela da Água Funda ............................................................................................ 76

Figura 42 Favela da Água Funda ....................................................................................... 76

Figura 43 Visão Geral do Conjunto Cingapura Miguel Stéfano ............................................... 77

Figura 44 Gráfico Questão 1 - FUNAPS ........................................................................ 100

Figura 45 Gráfico Questão 1 - Cingapura …….............................................................. 100

Figura 46 Gráfico Questão 2 - FUNAPS .................................................................... 101

Figura 47 Gráfico Questão 2 - Cingapura ..................................................................... 101

Figura 48 Gráfico Questão 3 - FUNAPS ........................................................................ 101

Figura 49 Gráfico Questão 3 - Cingapura ….................................................................. 101

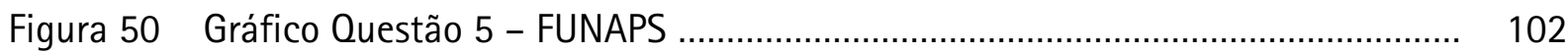

Figura 51 Gráfico Questão 5 - Cingapura .................................................................. 102

Figura 52 Gráfico Questão 6 - FUNAPS .................................................................... 102

Figura 53 Gráfico Questão 6 - Cingapura .................................................................. 102

Figura 54 Gráfico Questão 9 - FUNAPS ..................................................................... 102

Figura 55 Gráfico Questão 9 - Cingapura .................................................................... 102

Figura 56 Gráfico Questão 12 - FUNAPS ................................................................... 103

Figura 57 Gráfico Questão 12 - Cingapura ......................................................................... 103

Figura 58 Gráfico Questão 14 - FUNAPS .................................................................. 103

Figura 59 Gráfico Questão 14 - Cingapura .................................................................... 103

Figura 60 Gráfico Questão 17 - FUNAPS ..................................................................... 104

Figura 61 Gráfico Questão 17 - Cingapura …........................................................... 104

Figura 62 Gráfico Questão 19 - FUNAPS .................................................................. 104

Figura 63 Gráfico Questão 19 - Cingapura .................................................................... 104

Figura 64 Gráfico Questão 20 - FUNAPS .................................................................... 104

Figura 65 Gráfico Questão 20 - Cingapura …............................................................... 104

Figura 66 Gráfico Questão 22 - FUNAPS ....................................................................... 105

Figura 67 Gráfico Questão 22 - Cingapura .................................................................... 105

Figura 68 Gráfico Questão 23 - FUNAPS .................................................................... 105

Figura 69 Gráfico Questão 23- Cingapura ...................................................................... 105

Figura 70 Gráfico Questão 24 - FUNAPS ................................................................... 106

Figura 71 Gráfico Questão 24- Cingapura ..................................................................... 106

Figura 72 Gráfico Questão 25 - FUNAPS ................................................................... 106

Figura 73 Gráfico Questão 25- Cingapura ....................................................................... 106

Figura 74 Gráfico Questão 26 - FUNAPS ..................................................................... 106

Figura 75 Gráfico Questão 26- Cingapura ...................................................................... 106

Figura 76 Gráfico Comparativo por Domínios ............................................................. 107

Figura 77 Inserção Urbana dos Conjuntos ............................................................................ 114

Figura 78 Gráficos de Pontuação nos Domínios da Pesquisa Quantitativa ............................ 117

Figura 79 Gráfico Comparativo por Domínios ....................................................................... 121 
Lista de Tabelas

Tabela 1 Domicilios particulares permanentes, por Grandes Regiões ................................. 18

Tabela 2 Crescimento populacional do município de São Paulo de 1836 a 1980 ............. 22

Tabela 3 São Paulo: distribuição dos domicílios segundo a condição de ocupação ......... 23

Tabela 4 São Paulo: incremento da população favelada ..................................................... 27

Tabela $5 \quad$ Brasil: evolução do salário mínimo real (1940-1985) .............................................. 27

Tabela 6 RMSP: proporção de famílias pobres (ganhos até 1 SM per capita) ................... 29

Tabela $7 \quad$ Taxas de crescimento populacional, segundo anel município de SP (1960-96) 30

Tabela $8 \quad$ Percentuais dos recursos realizados pelo Fundo (1984-1996) .............................. 39

Tabela 9 Empreendimentos HABI - Ação em Favelas - Urbanização (infra-estrutura) ... 41

Tabela 10 Empreendimentos HABI - Ação em Favelas - Urbanização (infra-estrutura) ... 41

Tabela 11 Empreendimentos HABI - Provisão de Moradias - UH por Empreiteira ............ 42

Tabela 12 Empreendimentos HABI - Provisão de Moradias - Cortiços ................................ 43

Tabela 13 Empreendimentos HABI - Provisão de Terras e Moradias - UH por Mutirão .... 45

Tabela 14 Índices de custos médios FUNAPS ..................................................................... 48

Tabela 15 Realizações do Projeto Cingapura ....................................................................... 58

Tabela 16 Realizações do Projeto Cingapura por Região de São Paulo ................................. 59

Tabela 17 Índice de mora nos pagamentos ............................................................................... 61

Tabela 18 Custos de Edificações praticados nos Empreendimentos da 2a. Fase ................... 62

Tabela 19 Resumo dos custos do Campanha Gaúcha ............................................................. 67

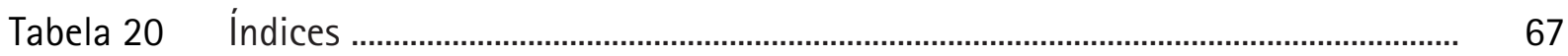

Tabela 21 Resumo dos Custos do Cingapura Imigrantes .................................................. 73

Tabela 22 Dimensionamento da Amostra ................................................................................ 99

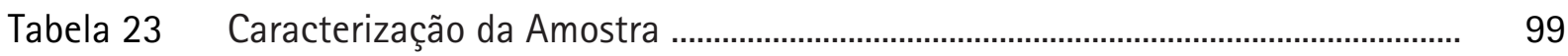


Lista de abreviaturas e siglas

\begin{tabular}{|c|c|}
\hline AID & Agência para o Desenvolvimento Internacional \\
\hline APROV & Departamento de Aprovação das Edificações do Município de São Paulo \\
\hline $\mathrm{BDI}$ & Benefício de Despesas Indiretas \\
\hline BID & Banco Interamericano de Desenvolvimento \\
\hline BIRD & Banco Internacional para Reconstrução e Desenvolvimento / Banco Mundial \\
\hline BNDES & Banco Nacional de Desenvolvimento Econômico e Social \\
\hline BNH & Banco Nacional da Habitação \\
\hline CAEHIS & Comissão de Avaliação de Empreendimentos HIS \\
\hline CBIC & Câmara Brasileira da Industria da Construção \\
\hline CCU & Centro Cooperativista Uruguaio \\
\hline $\mathrm{CDHU}$ & Companhia de Habitação e Desenvolvimento Urbano do Estado de São Paulo \\
\hline CEB & Comunidade Eclesial de Base \\
\hline CEF & Caixa Econômica Federal \\
\hline CEP & Central de Entidades Populares \\
\hline CLT & Consolidação das Leis do Trabalho \\
\hline $\mathrm{CMH}$ & Conselho Municipal de Habitação \\
\hline COBES & Coordenadoria do Bem Estar Social \\
\hline $\mathrm{COE}$ & Código de Obras e Edificações do Município de São Paulo \\
\hline $\mathrm{COHAB}$ & Companhia Metropolitana de Habitação de São Paulo \\
\hline CONTRU & Departamento de Controle do Uso de Imóveis \\
\hline DIS & Decreto de Interesse Social \\
\hline EHIS & Empreendimentos Habitacionais de Interesse Social \\
\hline EMPLASA & Empresa Paulista de Planejamento Metropolitano \\
\hline EMURB & Empresa Metropolitana de Urbanização \\
\hline ESP & Estado de São Paulo \\
\hline FABES & Secretaria Municipal da Família e Bem Estar Social \\
\hline FAR & Fundo de Arrendamento Residencial \\
\hline FAU & Faculdade de Arquitetura e Urbanismo da USP \\
\hline FCP & Fundação da Casa Popular \\
\hline FDS & Fundo de Desenvolvimento Social \\
\hline FGTS & Fundo de Garantia por Tempo de Serviço \\
\hline FIPE & Fundação Instituto de Pesquisa econômica \\
\hline $\mathrm{FMH}$ & Fundo Municipal de Habitação \\
\hline FMI & Fundo Monetário Internacional \\
\hline FUCVAM & Federación Uruguai de Cooperativas de Vivenda por Ayuda Mutua \\
\hline FUNAPS & Fundo de Atendimento à População Moradora em Habitação Subnormal (PMSP) \\
\hline GAP & Grupo de Assessoria e Participação \\
\hline $\mathrm{HABI}$ & Superintendência de Habitação Popular (SEHAB) \\
\hline HIS & Habitação de Interesse Social \\
\hline
\end{tabular}




\begin{tabular}{|c|c|}
\hline IAP & Instituto de Aposentadoria e Pensão \\
\hline IBGE & Instituto Brasileiro de Geografia e Estatística \\
\hline IBOPE & Instituto Brasileiro de Opinião Pública e Estatística \\
\hline ICMS & Imposto sobre Circulação de Mercadorias e Serviços \\
\hline IPT & Instituto de Pesquisas Tecnológicas do Estado de São Paulo \\
\hline IPTU & Imposto Predial e Territorial Urbano \\
\hline ISS & Imposto sobre Serviços \\
\hline |TB| & Imposto sobre a Transmissão de Bens Imóveis \\
\hline LPUOS & Lei de Parcelamento, Uso e Ocupação do Solo \\
\hline MOM & Movimento de Moradia \\
\hline OGU & Orçamento geral da União \\
\hline OMS & Organização Mundial de Saúde \\
\hline PAl & Plano de Ação Imediata \\
\hline PAR & Programa de Arrendamento Residencial \\
\hline PARSOLO & Departamento de Parcelamento do Solo e Intervenções Urbanas \\
\hline PNAD & Pesquisa Nacional por Amostra de Domicílios \\
\hline PMSP & Prefeitura Municipal de São Paulo \\
\hline PROCON & Fundação de Proteção e Defesa do Consumidor \\
\hline PROVER & Programa de Verticalização de Favelas (SEHAB) \\
\hline RESOLO & Departamento de Regularização de Loteamentos Irregulares (SEHAB) \\
\hline RMSP & Região Metropolitana de São Paulo \\
\hline RMRJ & Região Metropolitana do Rio de Janeiro \\
\hline SBPE & Sistema Brasileiro de Poupança e Empréstimo \\
\hline SEADE & Fundação Sistema Estadual de Análise de Dados \\
\hline SECOVI-SP & Sindicato da Habitação do Estado de São Paulo \\
\hline SEHAB & Secretaria Municipal de Habitação de São Paulo \\
\hline SEMPLA & Secretaria Municipal do Planejamento \\
\hline SERFHAU & Serviço Federal de Habitação e Urbanismo \\
\hline SFH & Sistema Financeiro de Habitação \\
\hline SFI & Sistema Financeiro Imobiliário \\
\hline SM & Salário Mínimo \\
\hline SINDUSCON & Sindicato da Indústria da Construção Civil \\
\hline SNH & Secretaria Nacional de Habitação \\
\hline SPSS & Statistical Package for the Social Sciences \\
\hline TPU & Título de Permissão de Uso Precário e Oneroso \\
\hline UMM & União dos Movimentos de Moradia \\
\hline UPF & Unidade Padrão Fiscal \\
\hline USP & Universidade de São Paulo \\
\hline VRF & Valor de Referência de Financiamento \\
\hline ZEIS & Zona de Especial Interesse Social \\
\hline
\end{tabular}


Sumário

Introdução

1 A construção do sonho da casa própria: urbanização, lutas urbanas e redemocratização 17

1.10 sonho da casa própria ...................................................................................................... 17

1.2 São Paulo: ocupação urbana e condições de moradia 1920- 1980 .................................... 21

1.3 Anos 80: a crise econômica e seus reflexos nas condições de vida da população ............ $\quad 27$

1.4 Políticas Públicas de habitação: lutas urbanas e a redemocratização .................................. 30

2 FUNAPS Comunitário e Cingapura .......................................................................................... 36

2.10 Programa FUNAPS Comunitário: 1989-1992 .................................................................. 36

2.1.1 Cenário existente para a concepção do Programa ................................................................. 36

2.1.2 A política habitacional na gestão Luiza Erundina: 1989-1992 ......................................... 39

2.1.3 0 Programa de Provisão de Moradias por Mutirão FUNAPS Comunitário ......................... 43

2.1.3.1 As diretrizes do Programa .................................................................................................. 44

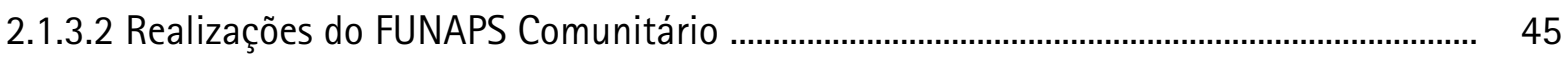

2.1.3.3 Os Custos do FUNAPS Comunitário ..................................................................................... 48

2.20 Projeto Cingapura: 1993-2000 ............................................................................................. 49

2.2.1 Cenário existente para a concepção do Programa ............................................................... 49

2.2.2 0 desmonte dos mutirões e a instalação do Projeto Cingapura na década de 90 .......... 50

2.2.3 As diretrizes gerais da política habitacional nas gestões 1993-1996 e 1997-2000 ...... 53

2.2.4 0 Projeto Cingapura ..................................................................................................... 55

2.2.5 Realizações do Projeto Cingapura .................................................................................... 58

2.2.6 Os Custos do Projeto Cingapura ...................................................................................... 62

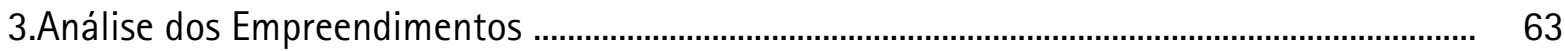

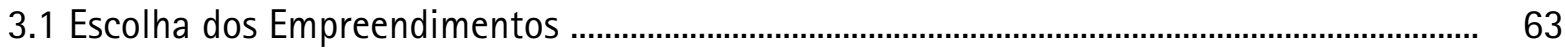

3.2 0 Conjunto Habitacional Campanha Gaúcha .......................................................................... 64

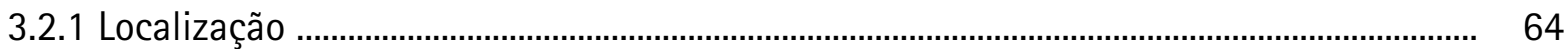

3.2.2 Histórico e Principais Características do Conjunto ....................................................... 64

3.2.3 Custos do Campanha Gaúcha ........................................................................................... 67

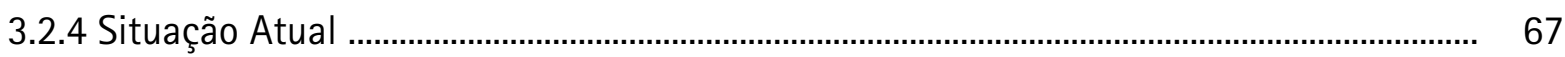

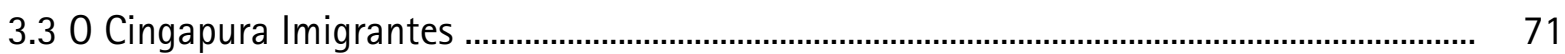

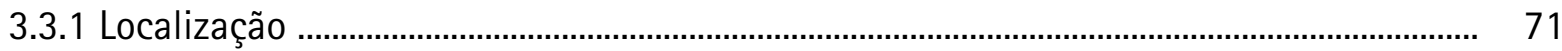

3.3.2 Histórico e Principais Características do Conjunto .............................................................. 71

3.3.3 Custos do Cingapura Imigrantes ....................................................................................... 73

3.3.4 Situação Atual ........................................................................................................... 73

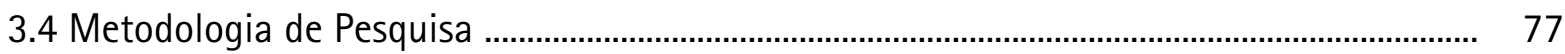

3.4.1 Método Qualitativo .......................................................................................................... 77

3.4.1.1 Apresentação de Resultados da Abordagem Qualitativa .............................................. 80 
3.4.1.2 Entrevistas analisadas do mutirão Campanha Gaúcha .................................................. 81

3.4.1.3 Entrevistas Analisadas do Cingapura Imigrantes ........................................................... 90

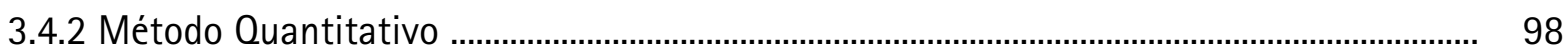

3.4.2.1 Apresentação de Resultados da Abordagem Quantitativa .............................................. 100

3.4.2.2 Apresentação comparativa dos resultados ...................................................................... 100

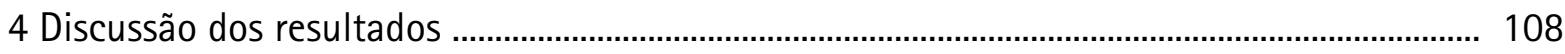

4.1 Discussão comparativa dos resultados da pesquisa qualitativa ........................................... 108

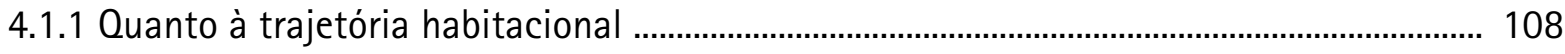

4.1.2. Quanto à apropriação e caracterização da moradia ........................................................... 110

4.1.3. Quanto à apropriação e caracterização do bairro ............................................................. 112

4.1.4 Quanto às expectativas, iniciativas e participação social ................................................... 114

4.1.5 Quanto à participação no processo de produção da moradia ……..................................... 116

4.2 Discussão dos resultados da pesquisa quantitativa ........................................................... 117

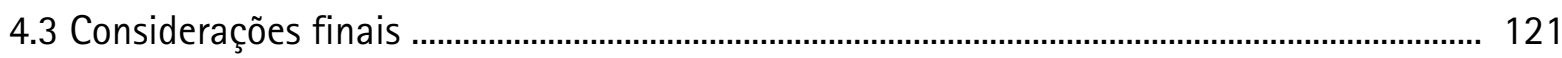

4.4 Limitações da pesquisa e possíveis desdobramentos ............................................................. 124

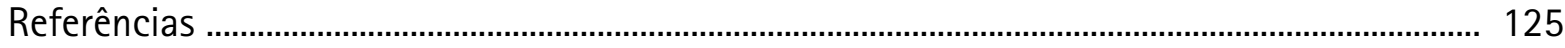

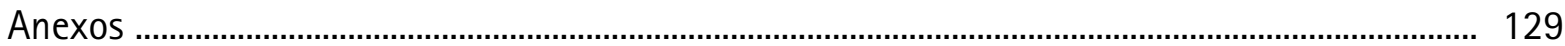




\section{introdução}

0 presente trabalho tem fortes influências dos últimos cinco anos de atividade profissional, em que tive oportunidade de trabalhar com projetos de habitação de interesse social em São Paulo e região metropolitana dentro do Programa de Arrendamento Residencial PAR'.

Nessa incipiente, porém turbulenta trajetória, acompanhei de perto o que pode ser chamado de um processo "tradicional" de produção habitacional a partir de programas estatais - desde a escolha do terreno, o projeto de implantação das unidades, a aprovação do projeto nos órgãos públicos, o financiamento da aquisição (ou compra da unidade) e a entrega do empreendimento.

Dentre as muitas questões que surgiram conforme eu tomava intimidade com o problema, a mais intrigante era a falta de qualquer tipo de participação dos moradores nas decisões que um projeto dessa natureza envolve. 0 pacote é entregue pronto à população, a quem caberá pagar em dia a prestação e zelar por aquilo que, talvez, daqui a 15 ou 20 anos, será seu.

Não é de se espantar que muitos desses conjuntos acabem por se constituir em "guetos" de violência ou que, pela repetição exaustiva da tipologia "H" de cinco pavimentos, tornem-se o estereótipo de "conjunto popular" no imaginário social.

A série de fotografias a seguir refere-se a conjuntos habitacionais produzidos Brasil afora entre os anos 1999 e 2005, no âmbito do PAR, competência do governo federal em parceria com os municípios.

Um mesmo "padrão" é adotado de norte a sul do país em municípios com realidades culturais totalmente diversas o que contraria um dos preceitos básicos da arquitetura: refletir a cultura na qual a obra está inserida.

\footnotetext{
'O PAR é um programa federal voltado para a população com renda familiar mensal de até seis salários mínimos, que consiste na aquisição de empreendimentos habitacionais (a construir, em construção ou a recuperar / reformar) por um fundo especifico (FAR - Fundo de Arrendamento Residencial) para arrendamento residencial.
} 

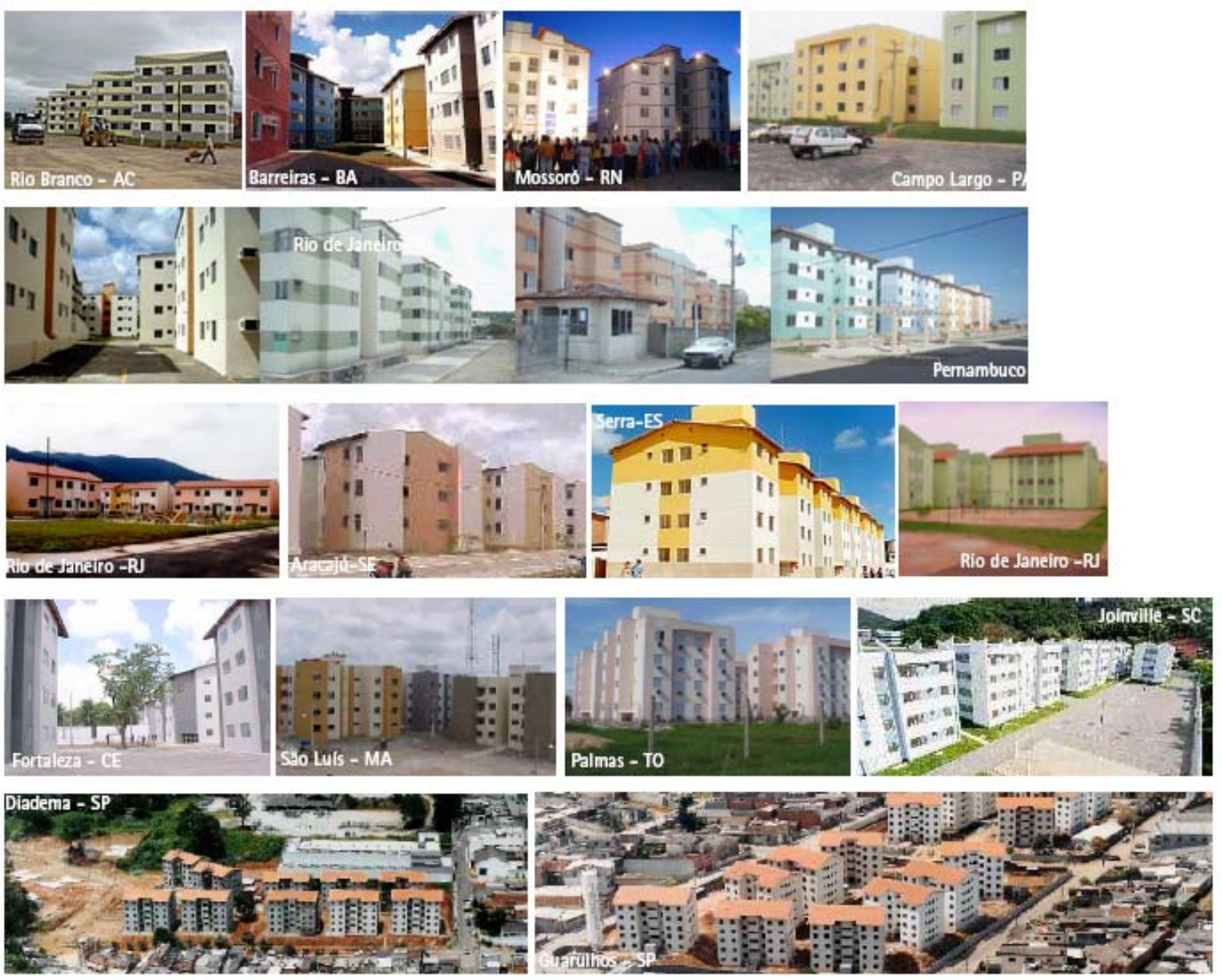

Figura 1 - Empreendimentos PAR em algumas cidades brasileiras ${ }^{2}$

Daí deriva o jargão "casinha de cachorro", freqüentemente utilizado pelo meio produtor (construtoras, projetistas, empreiteiros, contratantes, etc.) para definir habitação popular. De fato, se tomarmos a seguinte definição de Lemos para arquitetura, será improvável considerar arquitetura a maioria da produção pública contemporânea de habitação social no Brasil.

Arquitetura seria, então, toda e qualquer intervenção no meio ambiente criando novos
espaços, quase sempre com determinada intenção plástica, para atender as
necessidades imediatas ou as expectativas programadas e caracterizadas por aquilo
que chamamos de partido, seriam: - a técnica construtiva, o clima, as condições
físicas, o programa de necessidades, as condições financeiras do empreendedor. (...)
veremos que as variadas condições culturais sempre determinam arquiteturas
diferentes, não havendo possibilidades de repetições ou de identidades absoluta.
Queira-se, ou não, cada povo, em cada região terá a sua própria arquitetura. (LEMOS,
1989)

$\mathrm{Na}$ visão de alguns moradores dos conjuntos habitacionais promovidos pelo poder público na década de 80 em São Paulo, os responsáveis por planejar e executar a obra, não revelaram nenhum interesse pela população usuária:

\footnotetext{
${ }^{2}$ Montagem elaborada pela arquiteta Camila Maleronka para a defesa da dissertação de mestrado "PAR-Reforma: Quem se habilita?", em abril de 2005.
} 
Deve ter sido um engenheiro, ele deve ter pensado que era pros pobre, pobre que não têm casa, que vive de aluguel. Os engenheiros não conheciam quem vinha morar aqui não. Só pode ter feito pra gente pobre porque rico não compra essa casa porque é muito mal acabada. (...) Eles fazem só pensando nos lucros. (...) Fizeram pra uns favelado pensando nas piores pessoas. (...) Devem ter feito para pessoas de um nivel bem baixo, porque fez cômodos muito pequenos. As pessoas mesmo não iam construir assim. (BOTELHO, 1982, p.72)

Dentro desse contexto da produção de habitação de interesse social e procurando compreendê-la não somente como moradia produzida ou financiada por órgãos estatais destinada à população de baixa renda, mas como direito fundamental do cidadão ${ }^{3}$, indissociável de questões como o acesso a terra, a infra-estrutura e a serviços públicos, o presente estudo procura examinar quais as possiveis práticas que, com o uso racional de recursos, possam produzir moradias mais adequadas ou apropriadas à realidade social de seus usuários, e gerar com isso impactos sociais políticos e econômicos de maior alcance.

Para tanto esta pesquisa abordou um importante período do processo de democratização da produção habitacional na cidade de São Paulo, a década de 90, que compreende três gestões municipais entre os anos 1989 e 2000, sob dois aspectos principais:

- À luz da bibliografia existente, observando a evolução da intervenção pública no período considerado, no que se refere à produção de novas unidades habitacionais de interesse social promovidas pelo poder público municipal, no sentido de organizar dados e referências para futuros pesquisadores; e

- Através da avaliação dos próprios moradores tanto de suas moradias e do conjunto, quanto da sua qualidade de vida.

Dentro das políticas públicas de habitação adotadas no período, a pesquisa abrangeu os seguintes programas habitacionais:

- 0 FUNAPS Comunitário: Programa de habitação em autogestão, implantado em São Paulo durante a gestão 1989-1992, que beneficiou mais de 60 mil pessoas, viabilizou a edificação de 11 mil casas ou apartamentos em 84 empreendimentos com efetiva participação popular; e

- $O$ Projeto Cingapura: Criado em 1993, o Cingapura original prévia a construção de apartamentos -padrão de $42 \mathrm{~m}^{2}$ - em prédios de cinco pavimentos sem elevador, porém em sua fase final introduziu outras tipologias com 1, 2 e 3 dormitórios em torres de até 11 andares com

\footnotetext{
${ }^{3}$ Em 2000 a habitação passa a fazer parte dos direitos fundamentais do cidadão brasileiro, conforme Emenda ao Artigo 6o. da Constituição Federal. Está presente também na Declaração Universal dos Direitos Humanos em seu artigo 25 nos seguintes termos: "Todo homem tem direito a um padrão de vida capaz de assegurar a si e a sua familia, saúde e bem estar, inclusive alimentação, vestuário, habitação, cuidados médicos e os serviços sociais indispensáveis...".
} 
elevador. Foram entregues cerca de 918.000 unidades entre os governos Maluf e Pitta e a construção ficou a cargo de empreiteiras, não havendo participação popular em nenhuma das etapas.

É apresentada também uma análise dos impactos físicos e sociais do conjunto no entorno, a fim de estabelecer até que ponto essas realizações corresponderam às necessidades e expectativas populares e como elas foram apropriadas por seus moradores e pela cidade ao longo do tempo.

A forma como a metodologia de pesquisa foi concebida, centrada na opinião dos moradores, foi também uma tentativa de experimentar, na própria investigação acadêmica, maneiras novas e mais participativas de se avaliar a produção habitacional de interesse social.

Segundo Antunes (2002), a escolha do método é decorrente do enfoque que se quer dar a análise dos dados obtidos, que constitui essencialmente o pressuposto teórico adotado pelo pesquisador. Nesse sentido a metodologia buscada para essa pesquisa, foi aquela que permitisse trabalhar o problema dentro do seu próprio contexto, de forma a se obter uma visão sistêmica do objeto estudado, o que talvez possa ser considerado uma composição de vários métodos.

Assim, procurou-se analisar a relação que o morador tem com a casa - e não o objeto isolado - aproximando-se de um método utilizado nas investigações sociológicas baseado nas "práticas do cotidiano". Segundo Maria Irene Szmrecsanyi (1985), a riqueza extrema do cotidiano é a de abrigar à percepção da realidade no próprio ato de sua realização. A análise tem, necessariamente, de manter-se rente ao concreto, isso obriga a se penetrar na complexa variedade da criatividade humana, levando ao desvendamento das soluções-padrão e das fugas aos modelos.

Acompanhar a apropriação desses conjuntos pelos moradores e pela cidade, decorridos até 15 anos da implantação de alguns deles, expôs os impactos espaciais e sociais gerados por essas intervenções, tratando a questão habitacional em uma parcela de sua totalidade, maior do que aquela balizada somente por fatores econômicos.

Por fim, vale a pena ressaltar a crescente produção acadêmica referente à questão habitacional no Brasil, principalmente a partir dos anos 70, quando se configurou como tema específico de estudo (VALLADARES, 1983).

Trabalhos importantes vêm ajudando a consolidar no país uma linha de pesquisa sobre 0 tema, além de contribuir para o fortalecimento institucional da questão habitacional e urbana (como exemplifica a criação do Ministério das Cidades, em 2003), sendo este o intuito último dessa pesquisa: somar esforços para a formulação de políticas públicas mais eficientes: descentralizadas, transparentes e realmente focadas no interesse social. 


\section{Organização da Dissertação}

No primeiro capítulo, são investigadas, através de depoimentos, as raízes históricas do processo de construção do "sonho da casa própria". Também são discutidas as conseqüências do modelo desenvolvimentista - no qual a propriedade da moradia está inserida - para as condições de vida na metrópole e, por fim, são apontadas as principais realizações das políticas públicas de habitação da cidade de São Paulo dentro do contexto das lutas urbanas.

0 segundo capitulo trata especificamente dos dois programas habitacionais escolhidos como objeto de estudo: 0 Programa FUNAPS Comunitário e o Projeto Cingapura, onde se procurou ressaltar a postura do poder público neles expressa. As informações expostas neste capítulo visam subsidiar a discussão sobre o alcance social dos resultados obtidos pelos dois programas, proposta para o capítulo 4.

No terceiro capitulo são apresentados os dois empreendimentos escolhidos para a investigação proposta pela pesquisa, são eles:

- Conjunto Habitacional Campanha Gaúcha - viabilizado pelo FUNAPS Comunitário.

- Conjunto Habitacional Imigrantes - viabilizado pelo Projeto Cingapura

Também nesse capítulo é apresentada a metodologia de pesquisa utilizada para abordar os dois empreendimentos escolhidos e são expostos os resultados da pesquisa divididos em duas etapas: a pesquisa qualitativa, realizada através de entrevistas com os principais atores sociais envolvidos; e a pesquisa quantitativa, realizada através da aplicação de um questionário de avaliação de qualidade de vida desenvolvido pela Organização Mundial de Saúde - OMS.

No quarto e último capítulo são discutidos comparativamente os resultados obtidos na pesquisa qualitativa e quantitativa dos empreendimentos estudados, balizando-se no contexto histórico, apontado no primeiro capítulo, e na bibliografia consultada pertinente ao assunto. Também são apresentadas algumas conclusões a respeito de que forma os meios utilizados nos processos de acesso à moradia através dos programas públicos de habitação estudados influenciaram na vida de seus moradores nos mais diversos aspectos: sócio-culturais, políticos, econômicos e até mesmo físicos, lembrando que esta é a principal contribuição que este trabalho procurou trazer. 


\section{capítulo 1}

\section{A construção do sonho da casa própria: urbanização, lutas urbanas e redemocratização}

Neste capítulo são investigados os motivos que levaram e ainda levam as camadas mais pobres da população a perseguirem o acesso à casa própria.

Através de uma retrospectiva breve do processo de urbanização da cidade de São Paulo, são mapeadas as raizes históricas do processo de construção do "sonho da casa própria". Em seguida, são apresentadas as conseqüências do modelo desenvolvimentista - no qual a propriedade individual privada da moradia está inserida - para as condições de vida na metrópole. Por fim, são apontadas as principais realizações das políticas públicas de habitação da cidade de São Paulo dentro do contexto das lutas urbanas.

A intenção é investigar até que ponto essas políticas corresponderam às necessidades de moradia da população de baixa renda e entender quais as conseqüências trazidas pelas lutas urbanas por moradia, organizadas ou não, para a formulação dessas políticas.

\section{1 o sonho da casa própria}

Ter um teto para se abrigar da chuva, do frio ou do sol é a primeira, mas não a única razão que leva o ser humano a construir suas casas. A casa é o palco onde se desenvolvem as relações sociais privadas seja qual for a composição familiar. Assim, ela é carregada de elementos simbólicos que fazem parte do arcabouço cultural de uma sociedade.

As relações entre habitação e cultura têm sido estudadas principalmente pela antropologia, através da exploração das relações simbólicas entre o homem e sua casa ou abrigo'.

É flagrante nesse sentido, a relação intrínseca que mantêm os povos indígenas com sua habitação, descrita elegantemente por Lévi-Strauss ao visitar uma aldeia Bororo:

\footnotetext{
(...) após horas passadas em quatro patas, a trepar pelas encostas, transformadas em lama escorregadia pelas chuvas da monção que caiam sem parar: esgotamento físico, fome, sede e distúrbio mental, sem dúvida; mas essa vertigem de origem orgânica é toda iluminada por percepções de formas e de cores: habitações que pelo tamanho se tornam majestosas apesar da fragilidade, empregando materiais e técnicas conhecidas nossas como expressões menores, pois essas residências, mais do que construidas, são amarradas, trançadas, tecidas, bordadas e patinadas pelo uso; em vez de esmagar o morador sob a massa indiferente de pedras, reagem com flexibilidade à sua presença e a seus movimentos; ao contrário do que ocorre entre nós, estão sempre subjugadas ao homem (LÉVI-STRAUSS, 1996).
}

\footnotetext{
${ }^{1}$ Sobre este assunto, são exemplares os trabalhos de Bordieu sobre a casa Balila, de Lévi-Strauss sobre a aldeia Bororo e de Sylvia Novaes cujo título é "habitações indígenas".
} 
Essa simbiose entre a moradia e morador parece ter perdido a prioridade. A maior preocupação para a maioria dos brasileiros ao procurar uma casa é, sem dúvida, que ela seja de sua propriedade.

Uma pesquisa realizada pelo Instituto Brasileiro de Opinião Pública e Estatística - IBOPE ${ }^{2}$ em 2003 revelou que 50\% das pessoas mais pobres do país têm como "sonho de consumo" ter sua casa própria. No outro extremo, entre os 50\% mais ricos, esse "sonho de consumo" é ter uma casa própria maior ou uma mais confortável.

Para a maioria da população, possuir uma casa é mais do que um "sonho de consumo", é um elemento fundamental para sobreviver diante das vulnerabilidades do sistema econômico brasileiro.

Os dados expostos na tabela 1, resultado da última Pesquisa Nacional por Amostra de Domicílios - PNAD 2004 informam que a maioria dos domicílios brasileiros, mais de 70\%, são próprios ou estão em aquisição e apenas 15\% são alugados ${ }^{3}$.

Tabela 1 - Domicilios particulares permanentes, por Grandes Regiões, segundo algumas características

\begin{tabular}{|c|c|c|c|c|c|c|}
\hline \multirow{3}{*}{ Características } & \multicolumn{6}{|c|}{ Domicilios particulares permanentes } \\
\hline & \multirow{2}{*}{ Brasil } & \multicolumn{5}{|c|}{ Grandes Regiões } \\
\hline & & Norte & Nordeste & Sudeste & Sul & Centro-Oeste \\
\hline & \multicolumn{6}{|c|}{ Valores Relativos (\%) } \\
\hline Total & 100,0 & 100,0 & 100,0 & 100,0 & 100,0 & 100,0 \\
\hline \multicolumn{7}{|c|}{ Condição de ocupação } \\
\hline Próprio & 73,7 & 77,7 & 76,7 & 71,7 & 76,7 & 65,3 \\
\hline Já quitado & 69,4 & 76,3 & 74,7 & 66,3 & 70,5 & 61,6 \\
\hline Em aquisição & 4,2 & 1,4 & 2,1 & 5,3 & 6,2 & 3,7 \\
\hline Alugado & 15,4 & 11,0 & 12,3 & 17,8 & 13,8 & 19,5 \\
\hline Cedido & 10,4 & 10,6 & 10,6 & 10,0 & 9,0 & 14,6 \\
\hline Outra & 0,5 & 0,8 & 0,4 & 0,5 & 0,5 & 0,7 \\
\hline
\end{tabular}

No entanto, tais números devem ser entendidos dentro de uma perspectiva histórica do processo de urbanização brasileiro que, segundo Grostein (2001), "imprimiu às metrópoles pelo menos duas fortes características associadas ao modo predominante de 'fazer cidade': apresentam componentes de 'insustentabilidade' vinculados aos processos de expansão e transformação urbana e proporcionam baixa qualidade de vida a parcelas significativas da população."

Devido principalmente ao incremento do preço da terra urbana e à ausência de políticas públicas habitacionais empenhadas em resolver o problema, a autoconstrução foi a alternativa

\footnotetext{
2Disponivel em: www.ibope.com.br, acessado em 10 de fevereiro de 2003.

${ }^{3}$ Nesta pesquisa foi considerado: (a) próprio / já quitado - o domicílio de propriedade, total ou parcial, de moradores que estivesse integralmente quitado, independentemente da condição de ocupação do terreno; (b) próprio / em aquisição - para o domicilio de propriedade, total ou parcial, de morador e que não estivesse integralmente quitado, independentemente da condição de ocupação do terreno; (c) alugado - para o domicílio cujo aluguel fosse, totalmente ou parcialmente, pago por morador.
} 
encontrada pela população de baixa-renda, notadamente a partir da década de 70, para obtenção da casa própria.

A autoconstrução, feita de forma descolada de outros bens e serviços fundamentais de infra-estrutura básica, não significou melhoria da qualidade de vida nas cidades. Ao contrário, agravou o problema, pois fez com que ficasse cada vez mais custoso ao Estado estender as redes de infra-estrutura e equipamentos públicos às periferias. Até hoje, apenas $48 \%$ dos domicílios são atendidos por rede coletora de esgotos, conforme gráfico abaixo.

Figura 2 - Percentual de domicílios atendidos por alguns serviços no total de domicílios particulares permanentes, por Grandes Regiões

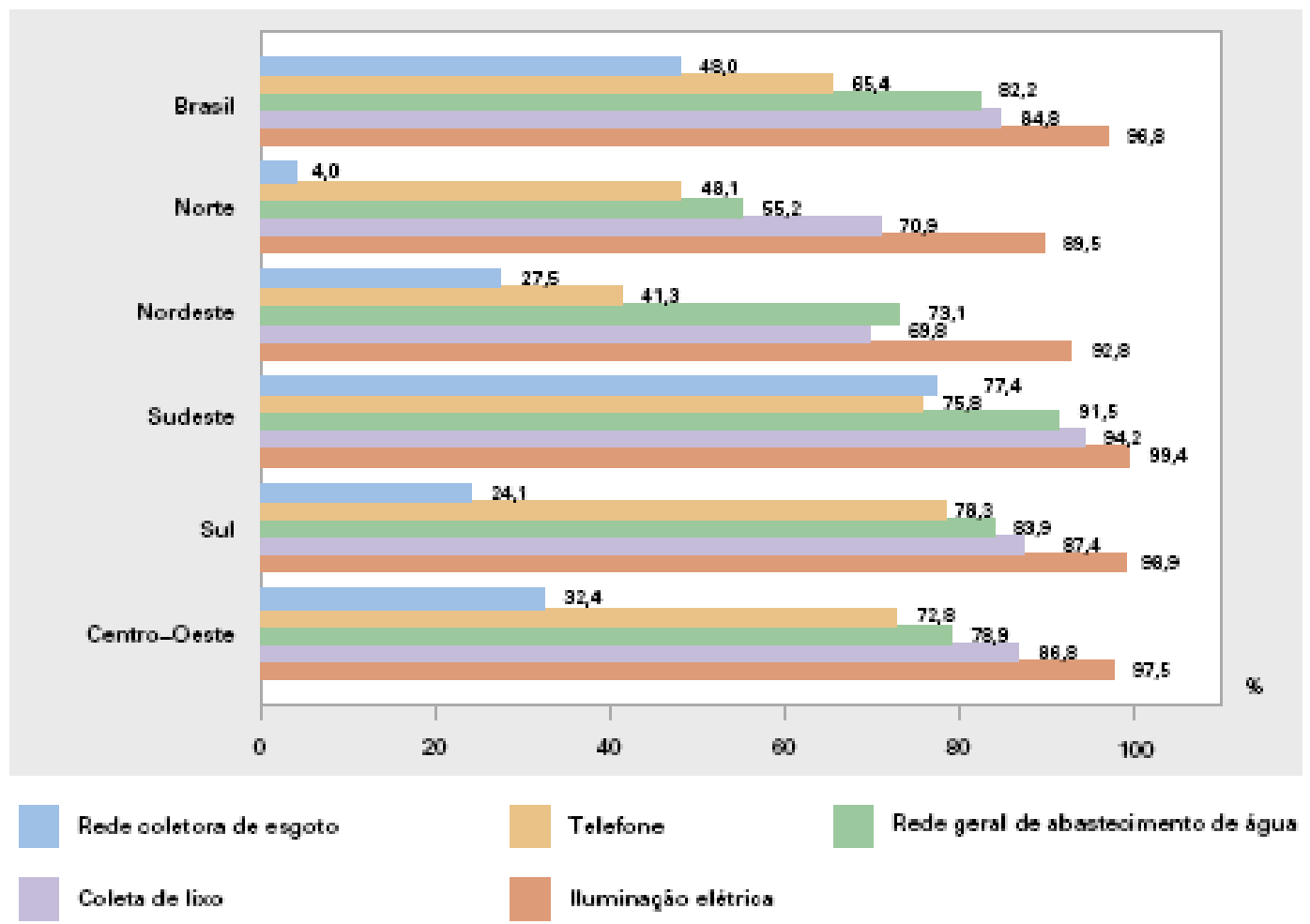

Fonte: PNAD 2004.

0 processo da autoconstrução constituía para as famílias um "drama habitacional". As parcelas intermináveis para aquisição do lote, muitas vezes ilegal, os finais de semana empregados na construção das casas, os constantes "serões" para obtenção de dinheiro extra para o material de construção, processo que poderia se estender por anos, era extremamente penoso, entretanto, na opinião dos autoconstrutores "valia a pena" (LIMA, 1981).

Os depoimentos transcritos a seguir, têm o propósito de ressaltar os motivos envolvidos na busca da casa própria na opinião dos principais envolvidos: os moradores. 
Os dois testemunhos abaixo, foram extraídos de um trabalho realizado em 1978 por Maria Helena Beozzo de Lima $^{4}$ na periferia do Rio de Janeiro que entrevistou autoconstrutores no Jardim Esperança, bairro da periferia da Região Metropolitana do Rio de Janeiro - RMRJ:

\begin{abstract}
"Quando eu cheguei aqui (no Rio de Janeiro) fui morá na favela... na casa do meu primo, lá no Acari. Aí eu arrumei esse emprego que eu falei, e eu comprei lá um barraco por quinhentos cruzero. Então, esse barraco eu fui ajeitando ele, fiz um comodozinho de tijolo, e foi esse que eu vendi pra comprar aqui... comprar um material, né. (...) Eu vendi porque lá num era meu, estava sujeito a qualquer momento ser tomado... ai nois decidimo vim pra esse terreno aqui... que é comprado... é nosso... é mais seguro." (eletricista)
\end{abstract}

"Meu sogro deu meia-água pra gente morá lá. Dois cômodo, morava eu, ela e as criança lá... num pagava nada. Mas nóis tinha aquela idéia: que num era nosso, que ele podia precisá dos cômodo... sempre isso na cabeça, aquela coisa de pensa assim ... que a gente só tá seguro mesmo no que é nosso. Sendo nosso é outra segurança... aconteça o que for tem seu canto, num tem precisão de sair nunca."(armador)

Embora tenham se passado 28 anos desses depoimentos, os motivos que levam os trabalhadores a buscarem a casa própria ainda continuam os mesmos, seja através da autoconstrução, seja através dos programas públicos de habitação, ou através do próprio mercado imobiliário: é ainda a única alternativa capaz de dar segurança ao grupo familiar nos momentos de crise.

Uma rápida comparação dos depoimentos anteriores com os três seguintes, trechos de entrevistas realizadas em setembro de 2005 com famílias que pleiteavam acesso a um conjunto habitacional em São Paulo, corrobora tal afirmação. Eles são uma amostra, ainda que limitada, das expectativas da população situada na faixa de 3 salários mínimos de renda familiar mensal, que buscam pela casa própria atualmente na cidade de São Paulo:

\begin{abstract}
"Ah, é uma coisa sua né, lógico que eu vou pagar um pouquinho mais, mas eu vou tá batalhando pelo o que é meu mesmo, alguém não precisa chegar e dizer, olha Cristina você precisa desocupar a casa, a gente gosta muito de você mas não vai dar pra você continuar. No apartamento não, é meu..., só se acontecer alguma coisa eu ter que devolver, ali eu vou criar uma raiz, vou poder arrumar uma escolinha pra minha filha até ela completar uma certa idade, não vou precisar ficar mudando de casa em casa ela perder ano de escola, isso é muito importante para que tem filho." (mulher com filha de dois anos moram em casa alugada)

"Ah se eu fosse falar a casa dos meus sonhos, a casa dos meus sonhos seria uma casa só minha, a minha casa sabe, com meu lazer só pra mim, sem outros dependentes fora.... onde a gente mora são três casas, mora a dona da casa e mais duas casas de aluguel. 0 meu sonho é uma casa só pra mim, pra eu chegar, entrar fechar meu portão, isso era meu sonho ter uma casa própria pra mim, eu não gosto de barulho, é tão bom sossego pra gente." (casal com 50 anos e um filho de 16 anos moram em uma casa de aluguel com mais duas no mesmo lote)
\end{abstract}

"Então o que a gente quer é morar junto, nós moramos de aluguel uns 6 meses, a gente pagava aluguel, ai a mulher precisou da casa e a gente teve que sair, é chato isso daí, aí a gente foi pra casa da minha sogra. A gente paga $R \$ 100,00$ pra ela por mês e estamos procurando outra casa pra gente morar, porque é ruim morar com a sogra né... 0 ideal é que fosse nossa, porque a gente paga aluguel pros outros e 0 dinheiro vai tudo embora... Acho que o sonho da maioria do pessoal é ter uma casa

\footnotetext{
${ }^{4}$ LIMA, Maria Helena Beozzo de. Em busca da casa própria: autoconstrução na periferia do Rio de Janeiro, in Habitação em questão. Rio de Janeiro, Zahar Editores, 1981.
} 
própria né... Acho que não existe uma casa ideal, sendo nossa é o que importa." (casal de 20 anos, uma filha de um ano, moram com os pais)

Como se vê, para além das questões econômicas, a casa própria é plena de significados sociais: respeito, dignidade, sucesso, "é a vitória de uma moralidade que valoriza a família unida, pobre porém honesta, o trabalho disciplinado, enfim, a vitória da perseverança que leva à conquista da propriedade" (KOWARICK, 2000, p.90).

Quem depende da economia informal ou de empregos temporários, não tem segurança para submeter-se a contratos de aluguel que exigem garantias formais do inquilino. A alternativa da locação ou da sublocação informal é pouco atraente, são os "contratos de gaveta", onde os despejos e cobranças abusivas são recorrentes.

Tudo isso faz com que a moradia de aluguel seja pouco quista e aceita somente como provisória, pois o "lar", onde se desenvolvem todas as relações sociais privadas, necessita de raízes, de relações de vizinhança para se fortalecer, "desenraizar as pessoas dificulta uma consolidação mais efetiva e afetiva dos laços familiares, elemento básico para enfrentar 0 cotidiano espoliativo de nossas cidades" (KOWARICK, 2000, p.90).

Por um outro ponto de vista, o papel da casa própria na vida do trabalhador, também pode ser entendido dentro da complexidade das relações de produção vigentes no país.

Para Engels, "sempre que o trabalhador investe suas pequenas economias na construção da casa própria, ele vai de certo modo convertê-la em capital para o capitalista. Isto porque o item aluguel, que deveria estar contido em seu salário, poderá ser deduzido, na medida em que ele não mais o paga. E o salário é o preço pago pelo os gastos de produção da força de trabalho. Deste modo, o operário continuará pagando aluguel dessa casa, só que agora não mais em dinheiro mas sob a forma de trabalho não pago ". (ENGELS apud BLAY, 1985)

Por esse ponto de vista, a autoconstrução, principal meio de acesso do trabalhador brasileiro à casa própria, só agravaria as condições de subsistência deste, mediante 0 rebaixamento dos salários ou a desvalorização da força de trabalho ${ }^{5}$.

De outro lado, Santos (1981) sustenta que, embora a autoconstrução represente um trabalho não-remunerado, a habitação autoconstruída é um bem que possui seu mercado de compra e venda, explicando seu atrativo para as classes populares.

0 fato é que esta foi a solução encontrada por milhares de brasileiros (não há precisão do número) para o problema da habitação. Estima-se que mais de 63\% das moradias da cidade de São Paulo até 1970 tenham sido autoconstruídas (TASCHNER e MAUTNER, s/d).

\footnotetext{
${ }^{5}$ Para uma análise do papel da autoconstrução na intensidade de exploração da força de trabalho e sua coerência com as necessidades de acumulação do capital, ver: OLIVEIRA, 1972.
} 


\subsection{São Paulo: ocupação urbana e condições de moradia 1920- 1980.}

0 desejo da casa própria tem fortes raízes na cultura do povo brasileiro. Embora em cada região o modelo desenvolvimentista adotado no país tenha adquirido nuances próprias, "o sonho da casa própria" será melhor compreendido se retomada a evolução do processo de ocupação urbana da cidade de São Paulo, baseado no trinômio loteamento periférico, casa própria e autoconstrução ${ }^{6}$ e utilizado em maior ou menor grau em todas grandes cidades do pais.

Esse padrão de ocupação vem sendo delineado desde as décadas de 1920 e 1930, quando se criaram novas condições de desenvolvimento urbano na cidade através da industrialização e se acentuou precisamente na década de 70, persistindo até os dias atuais.

Nos anos 20, São Paulo experimentou uma onda de crescimento impulsionada pelo aumento de produção da indústria paulista para atender a demanda do resto do país. Por força da própria conjuntura internacional, com a crise econômica mundial em 1929, o modelo de crescimento baseado na agroexportação se esgotou e foi iniciado, então, um processo de nacionalização da economia com base nas atividades urbano-industriais.

Atraídos principalmente pelo novo mercado de trabalho, entre 1900 e 1920 o número de habitantes da cidade cresceu 141\% (ver tabela 2), criando uma demanda por habitação nunca vista na cidade. 0 mercado imobiliário passou a ser uma forma atraente de reprodução do capital, com altas taxas de lucro. Investimentos individuais e companhias de capital aberto se multiplicaram na produção de casas de aluguel (BLAY, 1985, p.11).

Tabela 2 - Crescimento populacional do municipio de São Paulo de 1836 a 1980

\begin{tabular}{lcc}
\hline Ano & População & Incremento Percentual \\
\hline 1836 & 21.933 & \\
1872 & 31.385 & 43 \\
1886 & 47.697 & 52 \\
1890 & 64.934 & 36 \\
1900 & 238.820 & 168 \\
1920 & 579.033 & 141 \\
1934 & 1.060 .120 & 83 \\
1940 & 1.337 .844 & 26 \\
1950 & 2.198 .096 & 65 \\
1960 & 3.825 .351 & 74 \\
1970 & 5.978 .977 & 56 \\
1980 & 8.493 .598 & 42 \\
\hline
\end{tabular}

Fonte: BLAY, 1985, p. 10.

A cidade passou a contar com uma política de industrialização e com a maior intervenção do Estado regulamentando as relações trabalhistas ${ }^{7}$. 0 nível de fixação do salário

\footnotetext{
${ }^{6}$ Definição de BONDUKI, 1983. p. 137.

${ }^{7}$ Remontam aos anos 30, as grandes transformações na estrutura econômica e social do País. Foi nessa época que surgiram as primeiras leis regulamentando as relações entre trabalho e capital, além da Previdência Social beneficiando, principalmente, os segmentos sociais específicos da população urbana em processo de aceleração de crescimento, em vista da intensificação dos movimentos migratórios de origem rural.
} 
mínimo esteve em estudo durante a década de 1930, encontrando na habitação um item de consumo que absorvia boa parte dos salários dos operários, o que impedia seu rebaixamento (BONDUKI, 1983, p.144).

Começaram, então, a aparecer tentativas para criar condições de o trabalhador obter a casa própria como exemplifica a criação e regulamentação das carteiras prediais dos Institutos de Previdência em 1937 (BONDUKI, 1983, p.144).

Os próprios industriais se preocuparam em procurar soluções racionais e científicas para resolver o problema da habitação operária ${ }^{8}$, que constituía um obstáculo ao desenvolvimento da industrialização e ao aumento de produtividade no trabalho, pelos os altos custos dos aluguéis, que correspondiam a $79 \%$ do total de unidades habitacionais existentes na cidade, conforme tabela 03 abaixo.

Tabela 3 - São Paulo: distribuição dos domicilios segundo a condição de ocupação (em \%)

\begin{tabular}{lccccc}
\hline & 1920 & 1924 & 1940 & 1950 & 1970 \\
\hline Locatários & 78.6 & 74.5 & 67.7 & 59.3 & 38.2 \\
Proprietários & 19.1 & 23.8 & 25.0 & 37.7 & 53.8 \\
Outras condições & 2.3 & 1.7 & 7.3 & 5.2 & 8.0 \\
\hline & & & & & Fonte: BONDUKI, 1983. p. 146
\end{tabular}

Em 1920, os domicílios alugados na cidade de São Paulo correspondiam a 79\% do total de unidades habitacionais existentes na cidade. Já em 1950, 59\% e em 1970, década em que a população urbana do município praticamente dobrou em relação a anterior, essa porcentagem caiu para 38\%. Tal fato se deve menos ao incremento da casa própria e mais à intensa "favelização" da cidade. (BONDUKI, 1983, p.144).

Nesse período, São Paulo sofreu um processo de retalhamento das suas glebas suburbanas, impulsionado pela grande expectativa de lucro imobiliário gerada pelo agudo crescimento populacional (a população praticamente dobrou entre 1920 e 1930), o que acabou por colocar no mercado muito mais lotes do que a quantidade demandada.

Assim, em 1930, apenas 30\% dos $180 \mathrm{~km}^{2}$ de território loteado da cidade estava ocupado. Esse período de loteamento extensivo da periferia de São Paulo, realizado sem um correspondente potencial de ocupação, provocou uma queda acentuada da densidade demográfica bruta da cidade: de 110 hab/há, em 1914, para 47 hab/há, em 1930 (BONDUKI, 183, p.148).

Esses loteamentos não foram ocupados até a chegada do transporte coletivo baseado no ônibus, que mudou o padrão de ocupação da periferia da cidade. Por não existir a necessidade de percursos fixos, nem de grandes investimentos iniciais, rapidamente os ônibus passaram a servir as áreas mais periféricas da cidade. Este processo é descrito no trecho a seguir:

\footnotetext{
${ }^{8}$ Para uma análise aprofundada da relação do empresariado com o problema habitacional dos trabalhadores, ver: BLAY, 1985.
} 
A especulação imobiliária (...) adotou um método, próprio para parcelar a terra da cidade. Tal método consistia no seguinte: o novo loteamento nunca era feito em continuidade imediata ao anterior, já provido de serviços públicos. Ao contrário, entre o novo loteamento e o último já equipado, deixava-se uma área de terra vazia, sem lotear. Completado o novo loteamento, a linha de ônibus que o serviria, seria, necessariamente, um prolongamento a partir do último centro equipado. Quando se estendia linha de ônibus passava pela área não loteada, trazendo-Ihe imediata valorização (...). Desta forma transferia-se para o valor da terra, de modo direto e geralmente antecipado, a benfeitoria pública. (CARDOSO, 1973, p.9-10)

Visando abrir espaços para o automóvel e para a própria indústria automobilística, foi idealizado em 1930 por Prestes Maia o Plano de Metas. Implantado nas quatro décadas subseqüentes - em detrimento de um outro projeto para a cidade, elaborado em 1927 pela Companhia Light que privilegiava a manutenção do transporte sobre trilhos - o Plano de Metas acarretou graves comprometimentos para o meio ambiente urbano já que foi viabilizado utilizando as várzeas inundáveis dos córregos e rios.

No caso de córregos e rios menores, ganhou-se espaço diretamente sobre seus leitos, canalizados em galerias fechadas, sobre as quais foram construidas as vias de circulação; no caso do Tietê, Pinheiros e Tamanduateí, tratou-se do aprofundamento dos canais, através da definição de seções que garantissem o escoamento das vazões máximas previstas e construíram-se avenidas marginais junto ao limite dos canais, liberando a várzea para industrialização. (PMSP-SEMPLA, 1990, p.76)

Essas obras resultaram na impermeabilização massiva do solo urbano e no assoreamento constante dos rios. Em 1940, já eram dragados 120 mil metros cúbicos por ano de entulho do rio Tietê, sendo que em 1963 esse número elevou-se para 1 milhão e 500 mil metros cúbicos. (PMSP-SEMPLA, 1990, p.76).

Os problemas ambientais gerados por essa forma de urbanização, aliada ao uso do ônibus como principal transporte coletivo e a expansão do fluxo migratório incentivado pelo crescimento industrial, configuraram o modo precário e periférico de como a cidade cresceu.

Paralelamente à expansão periférica, o centro da cidade começou a se verticalizar devido à supervalorização dos terrenos na área central e às novas necessidades de divisão técnica do trabalho. Assim, os primeiros "arranha-céus" da cidade foram destinados a edifícios comerciais de aluguel. Essa tendência se acentuou por volta de 1928 quando a legislação de condomínio tornou possível a divisão dos edifícios e terrenos em frações ideais (PMSP-SEMPLA, 1990, p.110).

A conjuntura da Segunda Guerra Mundial e da inflação crescente, provocou o aumento dos aluguéis e uma valorização dos imóveis urbanos sem precedentes na cidade. Dessa forma, a expectativa de lucro do mercado imobiliário na compra e venda de imóveis se tornou muito maior do que a gerada pelo aluguel (BONDUKI, 1983, p.157).

Em 1942, ao congelar os aluguéis, a Lei do Inquilinato desestimulou acentuadamente a construção de imóveis destinados a este fim e provocou uma grande mudança no padrão da habitação popular. 
A política do Estado Novo de difundir a propriedade privada entre a classe média e trabalhadora, a carência de moradias no final da década de 40 e a industrialização acelerada de São Paulo que criou um mercado nacional de mão-de-obra, fizeram com que o loteamento na periferia, conjugado com a autoconstrução se tornasse, se não a única, a principal opção de moradia para o trabalhador, pelo menos até 1964.

A mancha urbana da cidade cresce de $180 \mathrm{~km}^{2}$ em 1930 para uma área de $700 \mathrm{~km}^{2} \mathrm{em}$ 1965. (ver figuras 3 e 4).
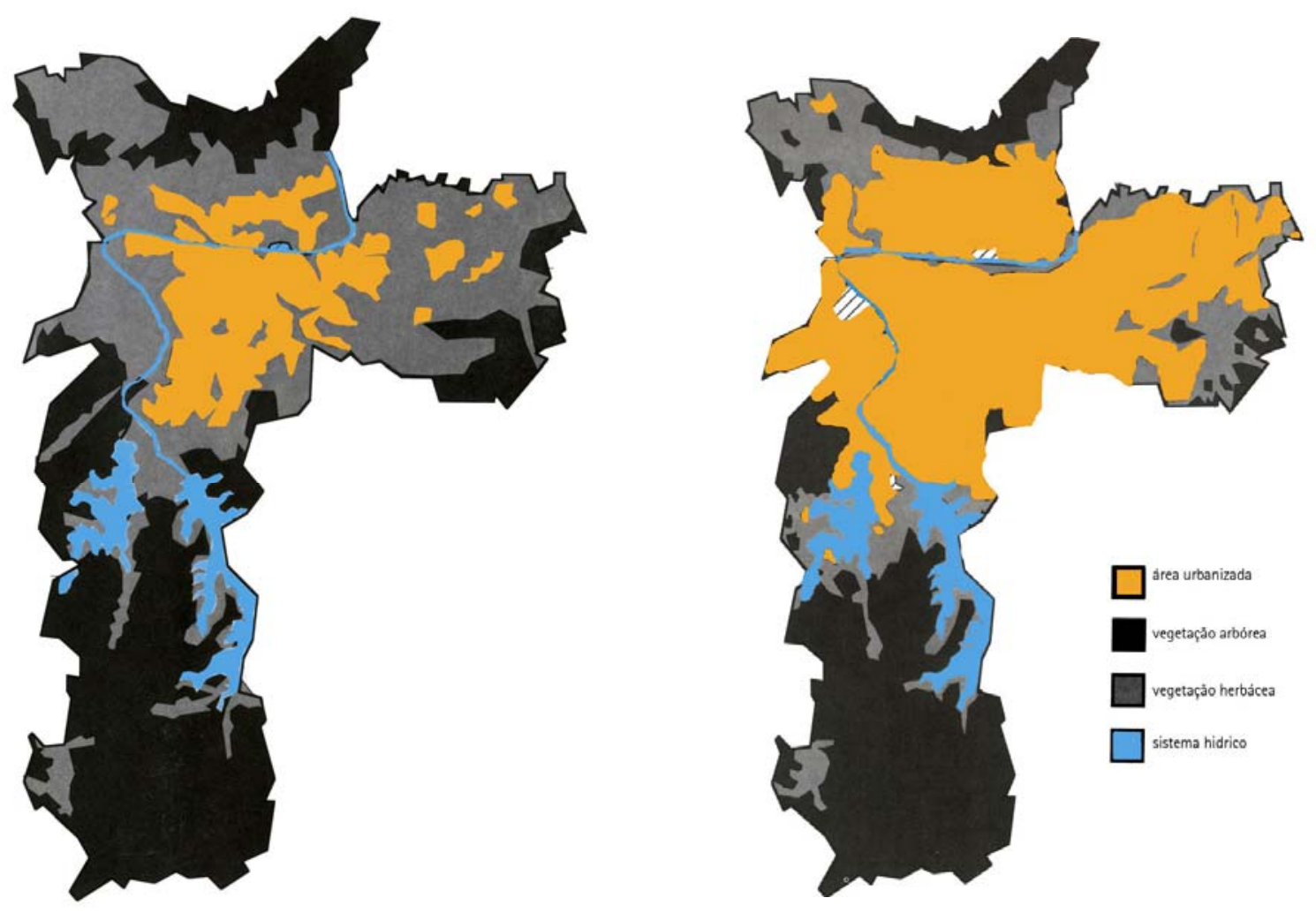

Figuras 3 e 4 - Mancha Urbana de São Paulo 1930 e 1965

A intensa urbanização da cidade foi acompanhada pela deterioração das condições de vida da população. 0 cenário urbano ficou marcado pela periferia, que se constitui de aglomerados urbanos clandestinos ou não, carentes de infra-estrutura, onde reside a mão-deobra necessária para o crescimento da produção.

Se, por um lado, possuir um teto significava mais segurança para o grupo familiar em momentos de crise ou desemprego, por outro, as penosas condições envolvidas no processo de autoconstrução, as grandes distâncias percorridas diariamente até chegar ao trabalho e o desconforto das casas, estava longe de compensar as dificuldades que ela acarretava.

Em meados dos anos 70 iniciou-se o esgotamento do já citado modelo de expansão periférica baseado no trinômio loteamento periférico, casa própria e autoconstrução, devido à 
escassez e conseqüente valorização geral dos terrenos, ao achatamento dos salários, e à legislação de parcelamento solo.

Na guerra pelo espaço urbano, intensificou-se a "favelização" que ocupou sobretudo os terrenos públicos da cidade. Dados da Coordenadoria do Bem Estar Social - COBES indicam que, das 1086 favelas do município de São Paulo, 41,9\% situam-se em terrenos públicos. Essa preferência, segundo Sachs (1999, p.87), se dá por uma garantia relativa de segurança de ocupação que permite que se criem aglomerações maiores, o que também confere à favela um poder de negociação maior.

A localização das favelas seguiu a lógica imposta pela industrialização, os barracos amontoaram-se em áreas próximas ao mercado de trabalho para a mão-de-obra não qualificada. Até 1970, o número de favelas era insignificante para a cidade, dez anos depois mais de 4\% da população estava morando em barracos e em 1987 já eram mais de 7\% da população os moradores de favela, conforme tabela abaixo.

Tabela 4 - São Paulo: incremento da população favelada

\begin{tabular}{|c|c|c|c|c|}
\hline & 1971 & 1973 & 1980 & 1987 \\
\hline População Total do Município & 5.480 .000 & 6.560 .547 & 8.558 .841 & 10.554 .107 \\
\hline População Moradora em favela & 41.100 & 71.840 & 375.023 & 812.764 \\
\hline \% de População Favelada & 0.75 & 1.09 & 4.40 & 7.70 \\
\hline
\end{tabular}

Algumas pesquisas desenvolvidas na década de 70 e $80^{\circ}$ procuraram relacionar os impactos das grandes desigualdades existentes na distribuição de renda, o acesso aos recursos de saúde e saneamento básico, educação e outros componentes das condições de vida na cidade brasileira, com os níveis da mortalidade infantil, sendo este um bom parâmetro para exemplificar as condições a que estava submetida a população da cidade de São Paulo no seu período de crescimento urbano mais intenso.

No Brasil, os níveis de mortalidade infantil se estabilizaram durante a década de 60 , em praticamente todas as regiões. No entanto, alguns estudos apontaram aumento da mortalidade infantil no Município de São Paulo nesse período (IBGE, 1999).

\footnotetext{
${ }^{9}$ GWATKIN, D. R. Indications of change in developing country mortality trends: the end of an era? Population and Development Review, New York, v. 6, n. 4, p. 615-644, Dec.1980 e PALLONI, Alberto. Mortality in Latin America: emerging patterns. Population and Development Review, New York, v. 7, n. 4, p. 623-649, Dec. 1981.
} 
Em 1960, a taxa de mortalidade infantil na cidade era de 62 entre mil nascidos. Em apenas dez anos esta taxa sobe para 90, como ilustra o gráfico abaixo.

Figura 5: São Paulo: evolução das taxas de mortalidade infantil 1960-1970

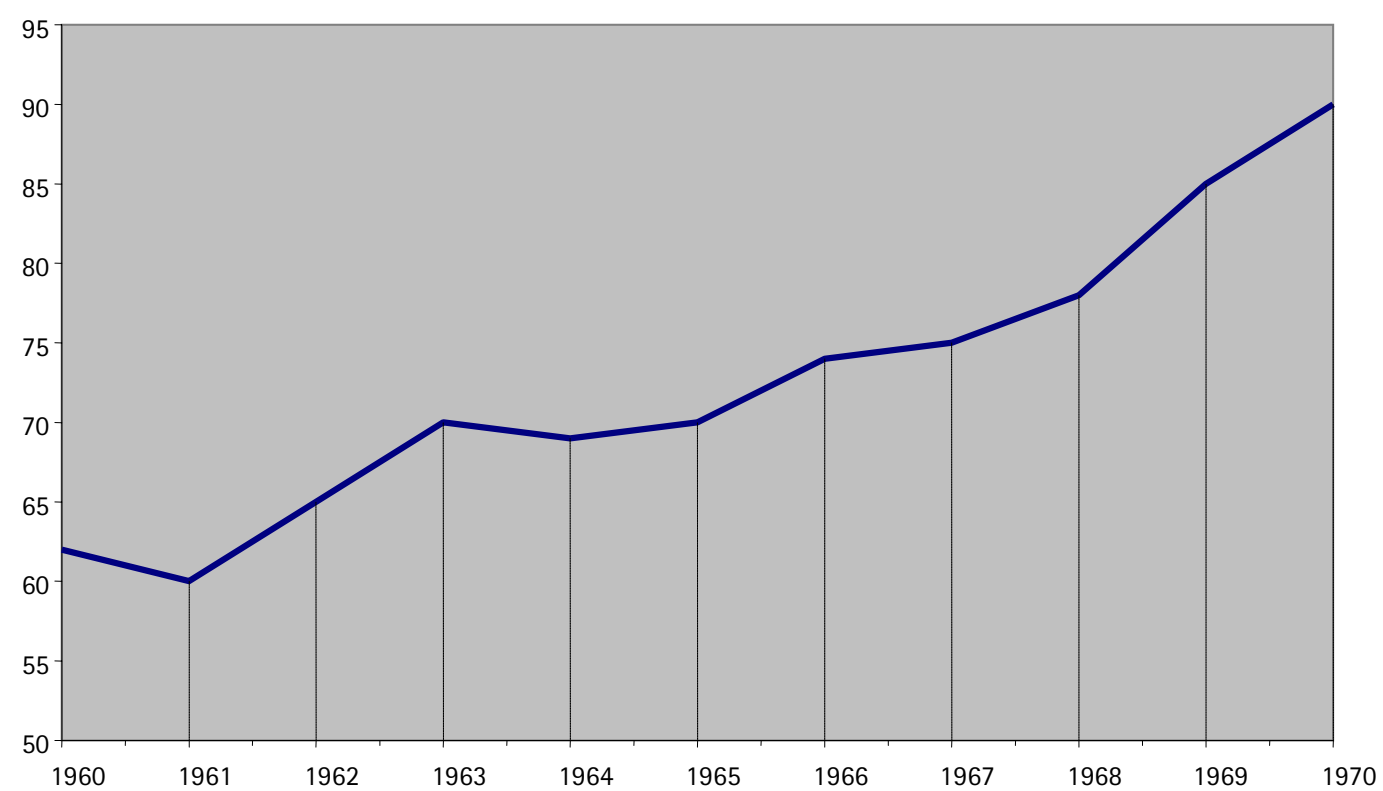

Fonte: CEBRAP, 1971, V.1, pág. 74

A crise urbana pela qual passava a cidade de São Paulo naquele periodo, representada pela pressão adicional sobre os serviços de infra-estrutura e de atendimento público causada pela explosão populacional ${ }^{10}$ talvez tenha sido a principal causa da interrupção do processo de declínio da mortalidade. Nos anos 70, as condições de vida em São Paulo, expressavam as condições impostas pelo modelo desenvolvimentista adotado em todo o país.

A peculiaridade da cidade, estava no fato desta representar a exacerbação do contraste entre acumulação e pobreza. 0 salário do trabalhador não acompanhou o crescimento, muito pelo contrário. A tabela 5 mostra a evolução real do salário mínimo de 1940 a 1985, ano em que chega a perder metade de seu valor de compra quando comparado a 1940.

Tabela 5 - Brasil: evolução do salário mínimo real (1940-1985) - base: 100, em julho de 1940

\begin{tabular}{lllllllllll}
\hline ano & 1940 & 1950 & 1960 & 1970 & 1980 & 1981 & 1982 & 1983 & 1984 & 1985 \\
\hline indice & 98.2 & 39.84 & 100.3 & 68.93 & 61.78 & 63.34 & 66.02 & 56.10 & 52.04 & 49.93 \\
\hline \multicolumn{1}{r}{} & & & & & & & Fonte: DIEESE apud SACHS, 1999)
\end{tabular}

0 caráter predatório e excludente do chamado "preço do progresso" ${ }^{11}$, determinou as condições da evolução urbana da cidade de São Paulo.

\footnotetext{
${ }^{10} \mathrm{~A}$ população urbana ultrapassou a população rural pela primeira vez na década de 70 e já em 1980 mais de $67 \%$ da população vivia em cidades (SACHS,1999).

${ }^{11}$ Segundo publicação da Arquidiocese de São Paulo de 1975, feita com o objetivo de informar a população, em principal as lideranças dos movimentos populares, das causas dos problemas urbanos da cidade, "... a noção de que o progresso tem um preço, que deve ser pago por seus habitantes tem sido insistentemente repetida a propósito dos
} 


\subsection{Anos 80: a crise econômica e seus reflexos nas condições de vida da população}

0 governo militar que assumiu o poder em 1964 no país, adotou como estratégia de crescimento econômico a abertura de mercado ao exterior. A facilidade de acesso à poupança externa nesse período, fez com que as taxas médias de crescimento do PIB girassem em torno de 8\% ao ano e do PIB per capita de 1,6\% ao ano, no intervalo de 1971 a 1975 (UGÁ, 1989).

No início dos anos oitenta houve uma reversão brusca nessa trajetória de crescimento e o país mergulhou na crise econômica mais grave de sua história, frente a uma enorme divida externa contraída na década anterior. A tímida recuperação apresentada no período de 198489 levou o valor do PIB apenas a retornar aos niveis observados no início da década, de forma que se popularizou a idéia de que os anos oitenta se constituíram para a economia brasileira na "década perdida".

A raiz dessa crise, que se manifestou inicialmente como uma crise de endividamento externo, passou rapidamente a se traduzir no desajuste interno da economia, está no aprofundamento do processo de substituição de importações, que levou o Estado brasileiro a assumir um padrão de financiamento baseado no endividamento externo crescente. Nesse processo, a participação do setor privado na dívida externa se reduziu de $67 \%$, no período 197273 para 23\% no final da década (CRUZ, 1983, p.57-106).

Diante da ascensão vertiginosa da divida externa, das restrições internacionais cada vez maiores à renegociação da dívida e à captação de novos recursos, o país se submeteu à tutela do Fundo Monetário Internacional - FMI. 0 receituário ortodoxo do FMI é conhecido: ao invés de tratar a balança comercial como resultado da política de desenvolvimento econômico, o Fundo inverte a lógica e subordina essa política a metas de aumento do saldo comercial. (OMETTO, FURTUOSO e SILVA, 1995, p.403-414).

Assumindo essa doutrina, o pais orientou suas prioridades para o aumento das exportações e retração do consumo interno, com vistas a reduzir as importações. Assim, assistimos, na década de oitenta, a uma das políticas de achatamento salarial mais vorazes, através da qual caiu velozmente a demanda interna de bens de consumo e duráveis. A queda do consumo, aliada às restrições às importações, provocou decréscimo na produção e, conseqüentemente, no nivel de emprego.

A metrópole paulista engendrou, então, uma deterioração violenta das condições de vida, resultado da combinação do empobrecimento da população somado à degradação das condições de moradia. Em 1983, havia cerca 1.5 milhão de desempregados na RMSP, o que significa 20\% da população economicamente ativa do período. Em 1987, mais de 42\% das

mais variados problemas: da poluição ambiental às carências do abastecimento, é em tudo consoante com a ideologia do desenvolvimento em voga: para que o país se desenvolva, assegurando a felicidade futura dos seus habitantes, estes devem renunciar às satisfações do presente..." 
famílias sobreviviam com menos de um salário mínimo mensal (BRANDÃO LOPES e GOTISCHALK, 1990, p. 100-109).

Tabela 6 - RMSP: proporção de famílias pobres (ganhos até 1 SM per capitã)

\begin{tabular}{lccccc}
\hline ano & 1981 & 1983 & 1985 & 1986 & 1987 \\
\hline familias pobres & $34.7 \%$ & $43.2 \%$ & $36.9 \%$ & $25.5 \%$ & $42.1 \%$ \\
\hline & & fonte: PNDAD apud BRANDÃO LOPES e GOTTSCHALK, 1990, p. 101
\end{tabular}

Nesse panorama de instabilidade, os mais atingidos foram os mais vulneráveis economicamente, ou seja, a mão-de-obra de pior qualificação. A valorização crescente de áreas em decorrência das melhorias urbanas feitas pelo poder público e a queda dos salários - quando não o desemprego - tornaram a possibilidade de comprar um lote e autoconstruir mais remota e a dificuldade de pagar o aluguel um drama para as famílias.

Dados dos Censos de 1980 e 1991, que fornecem valores de aluguel em salários mínimos, mostram que o aumento médio de aluguel no período foi de $69 \%$ para domicílios de apenas um cômodo, provavelmente encortiçados, de 36,6\% para os de dois cômodos e de $22,4 \%$ para os de cinco cômodos (BRANDÃO LOPES e GOTSCHALK, 1990, p. 100-109). 0 maior aumento foi justamente nos domicilios menores, geralmente ocupados pela camada mais pobre. Diante desse quadro, a alternativa de moradia para muitas familias foram as favelas ou cortiços, o que explica o aumento significativo da população de baixa renda nas áreas centrais.

Outro fenômeno alavancado pela crise dos anos 80 foi a migração da população de baixa renda para outros municípios da região metropolitana, o que explica as elevadas taxas de crescimento demográfico anual registradas na década de 80 . 0 deslocamento de moradores para o entorno da capital foi nítido. A região do estado que mais cresceu nos de 1960 a 1990 foi o cinturão de municípios da Grande São Paulo, com saldo migratório positivo de 440 mil moradores. Guarulhos foi a cidade paulista que mais cresceu nos anos 90, com taxa anual de 4,31\% e crescimento absoluto de 185 mil pessoas, das quais 100 mil por crescimento migratório (TASCHNER e BOGUS, 2001, p.31-44).

Aliado à periferização do crescimento populacional na metrópole, o município de São Paulo, apesar do crescimento mais reduzido, deve seu aumento de população também ao crescimento periférico, que, segundo Taschner e Bogus (2001, p.31-44), é resultado da periferizaçao das favelas, mais de $80 \%$ das unidades domiciliares faveladas, medidas pelo Censo de 1991, localizam-se nos anéis externos do município.

Essa tendência de crescimento do anel periférico, é acentuada nos anos 90 onde a totalidade do crescimento municipal, de quase 200 mil pessoas entre 1991 e 1996, foi devida ao aumento populacional na periferia, conforme dados da tabela abaixo. 
Tabela 7 - Taxas de crescimento populacional, segundo anel municipio de São Paulo 1960-1996

\begin{tabular}{lllcc}
\hline Anel & $1960-70$ & $1970-80$ & $1980-91$ & $1991-96$ \\
\hline Total & 4.79 & 3.67 & 1.16 & 0.40 \\
Central & 0.72 & 2.23 & -0.91 & -2.79 \\
Interior & 0.08 & 1.26 & -1.14 & -2.43 \\
Intermediário & 2.79 & 1.28 & -0.68 & -1.44 \\
Exterior & 5.52 & 3.13 & 0.86 & -0.51 \\
Periférico & 12.90 & 7.42 & 3.89 & 2.48 \\
\hline
\end{tabular}

Fonte: IBGE, 1960, 1970, 1980, 1991 e 1996.

A citação abaixo resume o movimento populacional ocorrido na cidade de São Paulo nos anos 80:

Em suma , um duplo percurso: de um lado, muitos habitantes pobres de São Paulo tiveram que deixar as casas das periferias e dirigir-se para os cortiços das zonas mais centrais; de outro, parte das camadas remediadas viu-se na contingência de abandonar as moradias situadas em zonas mais próximas ao Centro e rumar para compra ou aluguel de unidade situadas em áreas mais periféricas. Duplo percurso, porém com o mesmo sentido: a pauperização que desabou sobre a maioria daqueles que vivem em São Paulo.(PMSP-SEMPLA, 1990, p.58)

0 resultado de todo esse processo de empobrecimento é 59\% da população do município vivendo precariamente no final da década de 80: 8\% em favelas, 28\% em cortiços e 23\% morando em casas precárias da periferia (PMSP-SEMPLA, 1990, p.59).

Diante deste cenário de desigualdades e paralelamente a ausência histórica de políticas públicas de provisão habitacional que fizesse frente à realidade, se fortalecem os movimentos de luta por moradia e por melhores condições de vida.

\subsection{Políticas Públicas de habitação: lutas urbanas e a redemocratização}

0 propósito de inserir as principais realizações das políticas públicas de habitação da cidade de São Paulo dentro do contexto das lutas urbanas tem um duplo sentido: o de apontar qual a importância dessas políticas dentro das necessidades de moradia da população de baixa renda e o de entender as conseqüências trazidas pelas as lutas urbanas por moradia, organizadas ou não, para a formulação dessas políticas.

Como apontado anteriormente neste capítulo, o acesso á moradia é um fator importante de estabilização social. Assim, as primeiras intervenções do Estado brasileiro na questão da habitação são uma tentativa de minimizar os violentos efeitos do modelo desenvolvimentista adotado para o país nas camadas mais pobres da população. A conclusão do discurso do Sr. Paulo Accioly de Sá, delegado oficial no Primer Congresso Panamericano de la Vivenda Popular, em Buenos Aires, outubro de 1938, exemplifica essa postura do Estado:

Terminarei sintetizando a obra que o governo e o povo do Brasil procuram realizar. Dar a cada trabalhador uma casa que seja sua, casa individual, melhor dito, casa familiar, porque liberdade exige um mínimo de propriedade. 0 homem que nada possui é a verdadeira definição do anti-social. Nós queremos o homem livre, o homem feliz (citado em: BONDUKI, 1994). 
Longe de conseguir esse objetivo a criação das Carteiras Prediais dos Institutos de Aposentadorias e Pensões - IAPs em 1937, foi a primeira intervenção estatal concreta no setor de habitação popular. Segundo Bonduki (1983, p.145), a importância dos IAPs se deve menos ao número de unidades construídas e mais a tentativa de institucionalizar um novo padrão de habitação e de alterar o consenso de que o operário só poderia morar em casas alugadas, sem acesso à casa própria.

Como visto, a Lei do Inquilinato agravou a situação de carência de moradias para a população de média e baixa renda, gerando uma crise habitacional grave e, como conseqüência, o crescimento das forças de esquerda no país. Pressionado, o presidente Dutra deu à questão da moradia uma prioridade única. Simbolicamente, no dia $1^{\circ}$. de maio de 1946 , instituiu a Fundação da Casa Popular - FCP, primeiro órgão de âmbito nacional voltado exclusivamente à provisão, mediante venda, de casas para a população de baixa renda (AZEVEDO e GAMA DE ANDRADE, 1982).

A FCP não conseguiu produzir muito. Em 18 anos de existência construiu 18.132 unidades habitacionais, número pouco expressivo se comparado às 124.000 unidades construidas e/ou financiadas pelos IAPs entre 1937 e 1945 (TASCHNER, 1997, p.20).

Segundo Azevedo e Gama de Andrade (1982), o grande pecado do governo populista em relação à FCP não foi o de subsidiar a casa própria, mas o de subsidiar integralmente, o que era incompatível com os recursos financeiros limitados do Estado. Além disso, a seleção das cidades para a construção dos conjuntos, bem como a distribuição das unidades habitacionais, obedeciam a critérios clientelistas. Isso explicaria o fato da cidade de São Paulo, apesar de ser um grande centro urbano, não ter sido contemplada pelos investimentos da FCP.

Foi nessa época, através do populismo, que se deu o processo de incorporação das massas populares no processo político na cidade de São Paulo. Para isso, os expedientes clientelistas foram amplamente utilizados, baseando-se no oferecimento de vantagens pessoais ao eleitor ou benefícios governamentais a grupos ou camadas da população, em troca de apoio eleitoral. Esse foi o contexto das mobilizações populares dentro do getulismo, do ademarismo ou do janismo (CAMARG0, 176, p.108-109).

0 jogo eleitoral utilizado pelos governos populistas não significava poder de decisão da maioria, só influenciava os rumos do governo com a intenção clara de acarear votos. Assim, o populismo não colocava em questão a ordem política e econômica que trazia conseqüências nefastas para a população mais pobre, como exemplifica a própria FCP, que pela baixa produção, evidencia a falta de prioridade que os governos populistas concederam á questão habitacional.

Num contexto político autoritário e centralizador, os canais utilizados pela população de São Paulo para exprimir seus interesses foram as organizações de caráter reivindicativo, como é o caso das associações de bairro. 
Segundo Camargo (1976, p.117), as Sociedades de Amigos de Bairros surgiram em São Paulo no período de redemocratização do após-guerra e tiveram seu crescimento mais notável na década de 50, em um período de intensa movimentação política, em que tantos os partidos como as lideranças populistas disputavam as preferências da população. As organizações da população de baixa renda nas áreas mais carentes de recursos básicos, expressavam ao mesmo tempo a fraqueza política dos habitantes da periferia e a possibilidade de conquistarem força, pois o simples fato de se organizarem, introduzia um dado novo no balanço de forças da cidade (CAMARG0, 1976, p.119).

As associações de bairro atuaram até os primeiros anos da década de 60 tanto através de demanda pontuais em torno de serviços públicos e equipamentos sociais, como questionando a própria política e a forma de organização do poder municipal. Com o golpe militar, bloquearam-se as possibilidades de manifestação e pressão popular e o atendimento das demandas locais passou a depender exclusivamente da boa vontade do poder público.

Os sindicatos foram esvaziados tanto pelas restrições legais quanto pelos obstáculos políticos à movimentação dos trabalhadores. Mesmo assim, as movimentações dos trabalhadores em defesa dos seus interesses ultrapassam o âmbito dos sindicatos, como exemplifica as greves gerais de 1917, 1953 e 1957 na capital e em 1968 em Osasco (CAMARG0, 1976, p.126).

Diante desse quadro político, que desestimulava os indivíduos a se filiarem às organizações reivindicativas, grande parte da população procurou enfrentar as mazelas com os meios que suas relações sociais permitiam.

Segundo estudo realizado por Godinho (1974) ${ }^{12}$, em 1973, metade dos migrantes que chegaram a capital resolveu o problema da habitação através de vínculos familiares e 16\% através de amigos. Esse dado reflete a importância da ajuda mútua para as populações desprovidas de canais institucionalizados para atender suas necessidades. Segundo Berlinck (1976, p.139), 52\% da população mais pobre do município escolhe a localização da sua casa por influência de parentes, vizinhos ou amigos.

Tal cenário de marginalização e fragilidade institucional foi sustentado pelo poder político vigente. No final dos anos 60 , contingências externas levaram o governo do então presidente Jânio Quadros a dar importância significativa à questão habitacional.

A revolução cubana e a reforma urbana de Fidel Castro encontram eco nas massas empobrecidas da cidade. Para combater essa ressonância os Estados Unidos reuniram fundos de empréstimo para moradias populares da Agência para o Desenvolvimento Internacional - AID (TASCHNER, 1997, p.23). Porém, os planos ambiciosos de construir 100 mil moradias em 18

\footnotetext{
${ }^{12}$ Estudo baseado em 540 entrevistas, realizadas entre novembro e dezembro de 1973 com pessoas não naturais do município, que chegaram a São Paulo com mais de 14 anos, que em $80 \%$ dos casos a renda mensal não atingia três salários mínimos.
} 
meses do novo projeto intitulado "Instituto Brasileiro da Habitação" não sairiam do papel, devido a renuncia de Jânio.

É nesse contexto que se propõe uma nova estratégia para as políticas publicas de habitação baseado na já citada idéia de que a propriedade é fator de estabilidade política, conforme acentua a justificativa do novo plano habitacional.

0 status de proprietário dá ao trabalhador um senso mais elevado de responsabilidade,
levando-o a fazer todos os sacrifícios e empenhar seus esforços para mantê-lo. De
revoltado contra a ordem social, o beneficiário passará a ser um sustentáculo dela, um
homem que acredita na ascensão social. Há que contar com a mudança da
mentalidade que se opera no trabalhador, desejoso de, egresso do inferno, nunca mais
a ele retornar (AZEVEDO e GAMA DE ANDRADE, 1982, p.45).

Nesse sentido, as políticas públicas procuraram gerar uma forma de poder que retirasse das classes populares a sua autonomia e seu poder reivindicatório.

Em agosto de 1964, o governo militar criou o Sistema Financeiro da Habitação - SFH e o Banco Nacional da Habitação - BNH. Segundo Azevedo, os novos donos do poder que emergiram com a ditadura dariam feição diversa à política habitacional. Uma linha de solução empresarial tomaria o lugar do velho clientelismo que dominara até então (AZEVEDO e GAMA DE ANDRADE, 1982, p.57).

Cabe aqui ressaltar que, a escolha da habitação como eixo da política urbana do regime autoritário deveu-se principalmente à visibilidade da questão urbana através dos citados movimentos reivindicativos nos princípios dos anos 60 . No entanto, a própria fragilidade desses movimentos, sem a força necessária para enfrentar o problema, fez com que os rumos da política habitacional da ditadura assumissem um caráter muito mais econômico do que social.

Nos seus 22 anos de existência 4,5 milhões de unidades habitacionais foram construídas pelo BNH. Contudo, somente 250 mil unidades, o que significa 5,9\% do total foram destinadas à população com renda mensal abaixo de 3 salários mínimos (TASCHNER, 1997, p.40).

A crise econômica dos anos 80, o alto número de inadimplentes e o financiamento à infra-estrutura básica, dinheiro que raramente voltava aos cofres do $\mathrm{BNH}$, fez com que o banco encerrasse suas atividades em 1986. A partir daí, seus contratos e fundos foram transferidos para a Caixa Econômica Federal - CEF. A recessão econômica praticamente paralisou o setor, e, todas as possibilidades de novos financiamentos para setores populares foram fechadas, por resolução do Banco Central.

Desde então, o país ficou mergulhado num processo de desarticulação institucional para reger a política habitacional. Mais do que isso, segundo Maricato (1996), o que houve durante os anos subseqüentes ao regime militar foi, bem da verdade, uma política habitacional regida por uma aliança de interesses políticos clientelistas dos setores do capital de promoção imobiliária como o de construção. 
Sem amparo nas políticas públicas de habitação, a população continuou resolvendo o problema da moradia à revelia do Estado, mas não silenciosamente.

Desde o final dos anos 60 a Igreja Católica, através das Comunidades Eclesiais de Base CEBs, já vinha investindo na organização de moradores em torno do problema do acesso à moradia, que significava menor grau de mobilidade territorial, representava maior estabilidade das relações familiares, de vizinhança e de amizade favorecendo os atributos da própria religiosidade (DOIMO, 1989, p.101).

Durante a década de 70, foram essas pequenas aglutinações populares, menos perceptíveis, ligadas à pastoral operária, que aglutinaram os moradores em torno da luta por melhorias urbanas. Pequenas lutas por acesso à terra, habitação, transporte, água, esgoto e saúde foram se desenvolvendo fora das organizações institucionais. Para Kowarick (2000, p.74), "foram esses micro-acontecimentos que fizeram com que as consciências soterradas pela

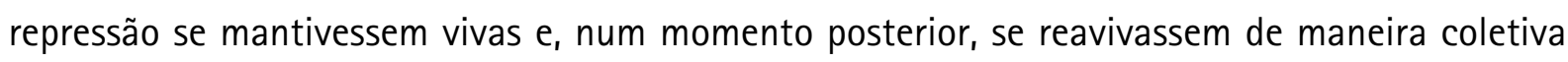
num movimento de reconquista de uma identidade contra o mundo dominante".

A década de 70 foi marcada pela emergência vigorosa de tais movimentos urbanos, que lutavam nos bairros por infra-estrutura e serviços públicos.

É por compartilhar um cotidiano precário na casa e no trabalho, que os movimentos operários se identificaram com os de luta por melhorias urbanas, culminando na histórica greve metalúrgica de São Bernardo do Campo de 1980 que contou com apoio maciço da população.

Da fundação da Pastoral de Favelas em 1967, voltada à luta por melhorias na cidade, até a criação do Movimento de Defesa do Favelado, foi se criando campo fértil para o desenvolvimento dos movimentos de moradia que culminou com a União dos Movimentos de Moradia - UMM, impulsionada pelas redes movimentalistas da zona leste de São Paulo (DOIMO, 1989, p.102).

Na década de 80, o Movimento de Moradia - MOM ganha uma dimensão nacional. Os sem-terra da cidade ocuparam terrenos nos grandes centros metropolitanos, publicizando a inexistência de políticas habitacionais para os trabalhadores pobres da cidade. Nesse processo de fortalecimento dos movimentos sociais, a situação política do país mudou e surgiram novas organizações e partidos políticos.

Amadurecida, a mobilização popular que reivindicava a criação de um possível Fundo Nacional de Moradia Popular conseguiu interferir nas decisões dos juízes e introduzir mudanças fundamentais na Constituição, sobretudo na legislação que tratava do uso do solo nas cidades.

Assim, a Constituição de 1988 estabeleceu, no artigo 182, que o objetivo da política urbana é "ordenar o pleno desenvolvimento das funções sociais da cidade e garantir o bem estar de seus habitantes". Estabeleceu também o Plano Diretor como instrumento básico dessa política, atribuindo poder aos municípios, o que resultou na ampliação da margem de atuação 
do poder local, embora condicionado à regulamentação federal. Em 2000, após aprovação de uma emenda constitucional, foi incluido no capítulo 6, o direito à moradia como direito social (AMARAL, 2001).

Este cenário, se não levou a uma maior convergência entre os interesses do cidadão e as diretrizes das políticas públicas sociais, acarretou maiores responsabilidades para os estados e municípios na formulação da política habitacional. 


\section{capítulo 2}

\section{FUNAPS Comunitário e Cingapura}

Convém frisar que o interesse desse estudo é investigar quais as práticas que dentro de uma política pública de habitação, possam produzir moradias mais adequadas ou apropriadas à realidade social de seus usuários e, com isso, gerar impactos sociais políticos e econômicos de maior alcance, que se traduzam na melhoria da qualidade de vida para todos.

Como dito na introdução desse trabalho, foram escolhidos como objeto de pesquisa dois programas habitacionais implantados na cidade de São Paulo na década de 90: o programa FUNAPS Comunitário, desenvolvido na gestão Luiza Erundina de Souza entre os anos 1989 e 1992 e o Projeto Cingapura, iniciado na gestão Paulo Salim Maluf entre os anos 1993 e 1996 e continuado na gestão Celso Pitta entre os anos de 1997 e 2000.

Neste capítulo, esses dois programas são expostos, sublinhando a postura do poder público neles expressa. Avaliar a produção de um programa habitacional não é tarefa fácil, são diversos tanto os fatores envolvidos no processo de implantação, quanto também podem ser os resultados alcançados. Balizar a avaliação de um programa somente pelo número de unidades construidas, empobrece a questão.

Uma das premissas desse trabalho é tratar qualitativamente a questão da habitação popular, numa parcela maior de sua totalidade que envolve, necessariamente, questões de desenvolvimento social, constituindo este o foco de análise dos resultados obtidos pelos programas estudados.

As informações que serão expostas nos tópicos a seguir visam subsidiar o escopo proposto para o capitulo 4 onde, juntamente com a avaliação dos moradores, pretende-se estabelecer uma discussão sobre 0 alcance social dos resultados obtidos pelos dois programas.

\subsection{Programa FUNAPS Comunitário: 1989-1992.}

\subsubsection{Cenário existente para a concepção do Programa}

0 processo de concepção do FUNAPS Comunitário está intimamente ligado ao quadro histórico em que o mesmo estava inserido. Como detalhado no capítulo 1, o rápido processo de urbanização, os fluxos e refluxos da economia, o cenário de instabilidade social provocado pelo aumento dos movimentos reivindicatórios, bem como as mudanças institucionais trazidas pela Constituição de 1988 são elementos fundamentais para entender como e por que esse programa foi criado. 
No final dos anos 80, em função da demanda ascendente por habitação e da mobilização popular crescente em torno da questão, era preciso que o poder público desse respostas rápidas e eficazes ao problema da moradia na cidade de São Paulo.

Por outro lado, começavam a aparecer na cidade as primeiras experiências de construção coletiva de moradia, organizadas e geridas pela própria comunidade. 0 mutirão e autoconstrução coletiva assistida passaram a ser uma opção de acesso à moradia, ainda que limitada.

Uma experiência pioneira na autoconstrução coletiva assistida foi o projeto "Vila Nova Cachoeirinha". Iniciado em 1981, apesar das dimensões reduzidas, esse projeto, tornou-se um novo paradigma em construção coletiva de habitações. Reinach (SACHS, 1999, p.174), arquiteto então responsável pelo projeto, relaciona os objetivos que nortearam o projeto como segue:

\footnotetext{
- mobilizar o esforço individual para atingir um objetivo coletivo; essa dimensão do projeto é essencial, a participação da população em cada uma das etapas do projeto concepção, organização do canteiro de obras, construção propriamente dita - tem um valor de aprendizado social e estimula a organização autônoma da comunidade a partir de uma experiência de ação solidária, voltada para a satisfação de uma necessidade vital, a habitação.

- racionalizar a produção da habitação e permitir ganhos de produtividade que se traduzem por uma redução do número de horas necessárias para a construção de uma habitação.

- realizar economias de escala, em particular no quesito materiais de construção, pela compra centralizada destes.

- melhorar a relação qualidade/preço do produto final em relação a autoconstrução individual.
}

A concepção desses objetivos teve forte influência das "Cooperativas de Ayuda Mutua" uruguaias. Em 1982 o engenheiro Guilherme Coelho, mentor do projeto Vila Nova Cachoeirinha, voltando de uma visita às cooperativas uruguaias, mostrou em diversos lugares (incluindo faculdades de arquitetura) um filme onde era possivel ver os resultados alcançados pelos trabalhadores uruguaios. Em 1984, representantes da Federación Uruguai de Cooperativas de Vivenda por Ayuda Mutua - FUCVAM e do Centro Cooperativista Uruguaio - CCU, participaram do Encontro de Moradia de Itapecerica da Serra, disseminando a experiência uruguaia (RONCONI, 1995, p.34).

Os maiores ganhos do projeto Vila Nova Cachoeirinha, além de ter conseguido oferecer um produto de qualidade superior na opinião dos arquitetos, foram ganhos sociais. Vila Nova Cachoeirinha abriu espaço para institucionalização dos processos autogestionários de produção de moradia dentro do governo municipal.

Outro fato importante para o desenvolvimento das políticas públicas municipais de habitação, foi a criação do Fundo de Atendimento à População Moradora em Habitação Subnormal - FUNAPS pela Lei n 8.906, de 27 de abril de 1979, nos últimos meses do governo do prefeito Olavo Setúbal. ${ }^{1}$ A criação desse fundo pode ser entendida como uma resposta do

\footnotetext{
' Os dados expostos a seguir sobre o FUNAPS foram inteiramente baseados em:ROSSETO, 2003.
} 
governo municipal à pressão da Igreja Católica, das comunidades de base e de organizações populares.

A existência desse instrumento jurídico-financeiro específico propiciou uma mudança radical de interpretação do poder público com relação às favelas. Elas deixavam de ser vistas como um câncer na cidade, que deveria ser extirpado pela remoção, para dar lugar ao entendimento de que eram comunidades formadas por trabalhadores e que, portanto, com ajuda pública, poderiam permanecer onde estava.

Desde a criação do $\mathrm{BNH}$, os recursos dos programas habitacionais destinados a atender a população de baixa renda fluiam para as $\mathrm{COHABs}$, que estavam atreladas às regras e políticas nacionais, resultando, dessa forma, em ações desvinculadas dos interesses políticos locais. A lei que criou o FUNAPS permitiu que o município começasse uma atuação autônoma em relação ao governo federal por meio da viabilização de novas diretrizes para a moradia.

0 FUNAPS possibilitou o atendimento à demanda constituída pela população residente no Município que ganhava até 4 salários mínimos regionais e morava em habitação considerada subnormal e os recursos poderiam ser aplicados a fundo perdido, colocando a prefeitura como uma alternativa local para aqueles que não podiam ingressar no Sistema Financeiro da Habitação - SFH. A administração direta atenderia com recursos orçamentários a população com renda até 4 ou 5 salários mínimos, por meio do FUNAPS, e a Companhia Metropolitana de Habitação de São Paulo - COHAB atenderia a população acima desse valor com recursos do SFH.

Com o FUNAPS, houve um salto qualitativo na política de atendimento municipal para a população de baixa renda. Mesmo sem ação direta do órgão responsável, foi possível contratar, assinar convênios, comprar e começar a responder ao objetivo de um atendimento mais coletivo nas favelas, como foi o caso já citado do projeto Vila Nova Cachoeirinha, em 1982.

Uma outra marca forte do FUNAPS foi a mudança fundamental em relação ao atendimento concebido anteriormente, totalmente subsidiado. Apesar da cultura assistencialista dos órgãos municipais começou a se buscar algum retorno dos recursos investidos. Os subsídios, distribuídos em todas as etapas, tornavam o pequeno retorno um elemento "didático", mostrando que estava sendo superada a fase clientelista da doação e sendo iniciada outra, em que o município colocava-se como agente promotor, preocupado com a produção, gestão e o repasse de bens e a prestação de serviços.

Durante o período Jânio Quadros, o FUNAPS foi utilizado para financiar a produção de moradias mediante a contratação de empreiteiras em consonância com a proximidade que a prefeitura tinha com o setor da construção civil. A aquisição de unidades habitacionais construidas por empreiteira elevou significativamente o custo unitário da unidade a ser financiada pelo fundo. 
Com a eleição da prefeita Luiza Erundina em 1989, os recursos públicos foram aplicados na periferia da cidade e procurou-se aumentar os gastos com as políticas sociais. Os dados constantes na tabela abaixo mostram que o governo Erundina imprimiu um novo patamar em relação aos recursos municipais destinados à moradia. Nos anos Erundina, o FUNAPS representou o principal canal de investimentos da Secretaria de Habitação - SEHAB, partindo de $44 \%$ e chegando a $77 \%$ dos gastos da secretaria.

Tabela 8: Percentuais dos recursos realizados pelo Fundo sobre o total do órgão responsável e deste sobre o total da PMSP (1984-1996)

\begin{tabular}{lccc}
\hline gestão & ano & \% do Fundo / total de SEBES ou SEHAB & \% de SEBES ou SEHAB / total da PMSP \\
\hline M. Covas & 1984 & 3.0 & 0.3 \\
& 1985 & 2.0 & 0.2 \\
\hline J. Quadros & 1986 & 20.0 & 1.0 \\
& 1987 & 35.0 & 2.0 \\
& 1988 & 23.0 & 1.0 \\
\hline L. Erundina & 1989 & 41.0 & 2.0 \\
& 1990 & 53.0 & 3.0 \\
& 1991 & 56.0 & 4.0 \\
& 1992 & 77.0 & 4.0 \\
\hline P. Maluf & 1993 & 70.0 & 2.0 \\
& 1994 & 23.0 & 2.0 \\
& 1995 & 8.0 & 2.0 \\
& 1996 & 9.0 & 4.0 \\
\hline
\end{tabular}

Fonte: Rosseto, 2003.

A lei do FUNAPS permaneceu em vigor até julho de 1994, quando a aprovação de uma nova lei criou, sob outro desenho institucional, o Fundo Municipal de Habitação - FMH.

\subsubsection{A política habitacional na gestão Luiza Erundina: 1989-1992}

Como resposta aos movimentos de luta por moradia - de onde saiu grande parte dos eleitores da prefeita Luiza Erundina - o governo municipal elaborou uma política habitacional pautada na ampla participação social nas formulações, implementações e decisões dos programas habitacionais. Essa opção definiu a linha geral de atuação da Superintendência de Habitação Popular - HABI, que priorizou o atendimento às famílias organizadas em associações e movimentos com o intuito de estimular a participação popular nos programas públicos de moradia. $^{2}$

As primeiras ações de $\mathrm{HABI}$ para atingir tal objetivo foram: (1) organizar canais de formais para a participação dos demandantes na nova política habitacional; (2) dar a Superintendência de Habitação Popular - HABI uma nova estrutura; (3) criar o departamento de regularização de loteamentos irregulares, o RESOLO; (4) formular uma política de habitação e desenvolvimento urbano voltada para a população de baixa renda e que tomasse como objeto a cidade real, com seus espaços informais; e (5) desapropriar terras, elaborar projetos e iniciá-los.

\footnotetext{
${ }^{2}$ Os dados expostos nesse item (2.1.2), foram baseados no Relatório de gestão 1989-1992 da SEHAB-PMSP.
} 
Ainda na fase inicial da gestão, foi elaborado o Plano de Ação Imediata - PAl que estabeleceu as seguintes diretrizes gerais adotadas para a política de habitação de interesse social:

- Destinação prioritária dos programas habitacionais à população com renda familiar até 5 salários mínimos.

- Prioridade para atendimento às reivindicações dos movimentos organizados de luta por moradia e de urbanização de favelas, bem como à produção de moradia para população moradora em favela de risco

- Desenvolvimento de trabalho social, cultural e político, visando o estimulo à participação da população

- Aumento da densidade populacional nos projetos de lotes urbanizados e construção de unidades habitacionais, sem prejuízo das áreas par uso habitacional e lazer.

- Utilização, além da prioridade individual do terreno e unidade habitacional, de outras alternativas de garantia da posse da moradia, como: concessão do direito real de uso, propriedade coletiva, condominial e cooperativa.

- Respeito à proporcionalidade entre a extensão da demanda, a organização dos movimentos e a gravidade da situação de risco, no momento da distribuição dos projetos a serem implantados, devendo todas as zonas do município serem atendidas.

- Estímulos as soluções de caráter inovador no que se refere à qualidade do projeto, processo de produção ou regime de propriedade, como subsídio ao estabelecimento de nova política de habitação de interesse social.

- Mobilização de outros recursos financeiros, além dos provenientes do orçamento municipal, na implantação do plano.

- Obtenção de terras para desenvolvimento dos projetos habitacionais, através de: utilização de glebas da COHAB-SP; utilização de glebas ou terrenos comprados por movimentos ou associações com recursos próprios ou outras fontes e utilização de glebas ou terrenos particulares, mediante aquisição ou desapropriação. (PMSP, 1992)

Os programas utilizados por $\mathrm{HABI}$ para colocar estas diretrizes em prática foram divididos em dois grandes grupos: Ação Favela (a) e Construção de Habitação de Interesse Social - HIS (b). A descrição dos programas e subprogramas é apresentada abaixo.

\section{(a) Ação em Favela}

\section{(a.1) Urbanização de Favelas-Construção}

Objetivou regularizar jurídico e fisicamente as favelas com a intenção de fixar a população moradora no local e inserir gradativamente o assentamento no tecido urbano.

A regularização fundiária jurídica se deu através da concessão do direito real de uso ou usucapião urbano.

Foram priorizadas as favelas que contavam com a população organizada e situadas em áreas públicas com características físicas favoráveis à urbanização.

Para viabilização das intervenções foram desenvolvidos três subprogramas: (1) Obras por empreiteira; (2) FUNAPS-Urbanização, obras de infra-estrutura, executadas por mutirão; e (3) FUNAPS-Favela, unidades habitacionais em favela, executadas por mutirão

0 convênio FUNAPS-Urbanização (URBANACOM), assim como o FUNAPS-Favela, permitiu às associações organizadas de moradores de favela o gerenciamento das verbas para a 
contratação de assessoria técnica, compra de materiais e execução das obras de infra-estrutura, em regime de mutirão. 0 limite máximo de recursos para a execução dos serviços de urbanização esteve na faixa de 150 a 210 UPF/familia.

A intenção primordial desses programas, mais do que viabilizar um processo de execução de obras, foi constituir um processo educativo pautado na capacidade do trabalho coletivo. A tabela abaixo resume as realizações desses programas

Tabela 9 - Empreendimentos HABI - Ação em Favelas - Urbanização (infra-estrutura)

\begin{tabular}{|c|c|c|c|c|}
\hline & \multicolumn{2}{|c|}{$\begin{array}{l}\text { Infra-estrutura em favelas } \\
\text { (familias atendidas) }\end{array}$} & \multirow[t]{2}{*}{ total } & \multirow[t]{2}{*}{ total $\%$} \\
\hline & concluídas & não concluídas & & \\
\hline Leste 1 & 128 & 2.699 & 2.827 & 10.4 \\
\hline Leste 2 & 1.019 & 5.212 & 6.231 & 22.9 \\
\hline Norte & 52 & 487 & 539 & 2.0 \\
\hline Oeste 1 & 379 & 1.273 & 1.652 & 6.1 \\
\hline Oeste 2 & 229 & 3.296 & 3.525 & 13.0 \\
\hline Sudeste & 3.357 & 2.689 & 6.046 & 22.3 \\
\hline Sul 1 & 205 & 2.879 & 3.084 & 11.4 \\
\hline Sul 2 & 500 & 2.753 & 3.253 & 12.0 \\
\hline Total (famílias) & 5.869 & 21.288 & 27.157 & \\
\hline Total (\%) & $21,6 \%$ & $78,4 \%$ & $100 \%$ & \\
\hline
\end{tabular}

Fonte: PMSP, 1992.

\section{(a.2) Prevenção de Risco}

Caracterizou-se por intervenções nas situações de risco em favelas, através da remoção parcial ou total das familias para empreendimentos de provisão de moradia.

0 quadro abaixo, mostra as intervenções realizadas por empreiteiras ou por mutirão, em 44 favelas do município de São Paulo.

Tabela 10 - Empreendimentos HABI - Ação em Favelas - Urbanização (infra-estrutura)

\begin{tabular}{lccc}
\hline & \multicolumn{2}{c}{$\begin{array}{c}\text { Unidades Habitacionais em favelas } \\
\text { (familias atendidas) }\end{array}$} & total \\
\hline & concluídas & não concluidas & \\
\hline Leste 1 & 0 & 241 & 241 \\
Leste 2 & 44 & 229 & 273 \\
Norte & 77 & 76 & 153 \\
Oeste 1 & 66 & 0 & 66 \\
Oeste 2 & 61 & 181 & 242 \\
Sudeste & 0 & 40 & 40 \\
Sul 1 & 0 & 469 & 469 \\
Sul 2 & 0 & 57 & 57 \\
Total (famílias) & 248 & 1.293 & 1.541 \\
Total (\%) & $16,1 \%$ & $83,9 \%$ & $100 \%$ \\
\hline
\end{tabular}

Fonte: PMSP, 1992.

\section{(a.3) Melhorias}

Constituiu-se de obras pontuais e emergenciais executadas por mutirão. Essa opção era utilizada quando não havia viabilidade técnica de implantação de uma urbanização ou quando 
havia alguma indicação para remoção futura da favela. Foram atendidas através desse Programa 76 favelas. Por dispensar mecanização e utilizar mão-de-obra da própria favela, ao final da gestão, 83\% das obras tinham sido concluídas.

\section{(a.4) Regularização Fundiária}

De grande importância para viabilizar os objetivos propostos na política habitacional, a regularização fundiária pretendida se faria através da desafetação de áreas públicas municipais ocupadas por favelas passiveis de urbanização e pela outorga da concessão de direito real de uso aos ocupantes cadastrados pela prefeitura. Com esse objetivo foi apresentado o Projeto de Lei 51/90 à Câmara. Porém, interesses diversos e a complexidade jurídica envolvida na questão da posse de terra, dificultaram a ação da Superintendência de Habitação Popular que, ao término da gestão, só havia conseguido adquirir 9,09\% do total de terras pretendidas (BUAROUE, 1998, p.19).

\section{(b) Construção de HIS - Habitação de Interesse Social}

\section{(b.1) Aquisição de Terras}

Para a seleção de áreas a serem utilizadas pelos programas habitacionais, consideravamse os seguintes aspectos: acessibilidade; características de ocupação do terreno e do entorno; grau de inserção na malha urbana; existência de infra-estrutura básica e equipamentos; condições topográficas e geotécnicas e restrições legais. Após essa seleção, era iniciada a ação expropriatória. Até a imissão de posse era um longo caminho acompanhado de muita expectativa pela população.

\section{(b.2) Construção por empreiteira (UH+Infra)}

0 objetivo desse Programa foi ofertar moradia para famílias de baixa renda que estivessem em situação de risco e organizada em associações. Esse Programa, feito por empreiteiras, finalizou 3.749 moradias com infra-estrutura e deixou outras 3.793 em obras no final de 1992. 0 quadro abaixo, resume as realizações desse Programa:

Tabela 11 - Empreendimentos HABI - Provisão de Moradias - UH por empreiteira

\begin{tabular}{lcrrr}
\hline & \multicolumn{2}{c}{$\begin{array}{c}\text { U. H. por empreiteira } \\
\text { (familias atendidas) }\end{array}$} & $\begin{array}{c}\text { Total } \\
\text { (famílias) }\end{array}$ & total \% \\
\hline Leste 1 & concluídas & não concluídas & & 8.5 \\
Leste 2 & 330 & 881 & 1.211 & 30.6 \\
Norte & 1.256 & 3.139 & 4.395 & 1,7 \\
Oeste 1 & 14 & 234 & 248 & 14.6 \\
Oeste 2 & 904 & 1.183 & 2.087 & 15 \\
Sudeste & 750 & 1.400 & 2.150 & 5.5 \\
Sul 1 & 185 & 599 & 784 & 20.3 \\
Sul 2 & 302 & 2.609 & 2.911 & 3.8 \\
Total (famílias) & 8 & 543 & 551 & 14.337 \\
Total (\%) & 3.749 & 10.588 & 100 & \\
\hline
\end{tabular}




\section{(b.3) Construção por mutirão (UH)}

0 FUNAPS Comunitário foi o Programa responsável pela provisão de moradias através do mutirão. Como esse programa faz parte do objeto dessa pesquisa, ele será alvo de uma exposição mais detalhada na seqüência desse capítulo.

\section{(b.4) Cortiço (UH)}

Propôs, através de experiências piloto, o início de um trabalho de atendimento à população moradora em habitação coletiva precária de aluguel através de assistência jurídica, social e física. 0 Programa de cortiços apresentou duas linhas básicas: produção de habitações com um limite máximo de financiamento de 2.100 UPF por família e recuperação de cortiços através de financiamentos às associações de moradores para a aquisição de imóveis e posterior reforma. As realizações desse Programa foram as seguintes:

Tabela 12: Empreendimentos HABI - Provisão de Moradias - Cortiços

\begin{tabular}{lccc}
\hline & \multicolumn{2}{c}{$\begin{array}{c}\text { U. H. por empreiteira } \\
\text { (familias atendidas) }\end{array}$} & $\begin{array}{c}\text { Total } \\
\text { (famílias) }\end{array}$ \\
\hline Centro & concluidas & não concluídas & \\
Leste1 & 0 & 190 & 190 \\
Sudeste & 0 & 227 & 227 \\
Total (familias) & 0 & 64 & 64 \\
\hline
\end{tabular}

Fonte: PMSP, 1992.

\subsubsection{Programa de Provisão de Moradias por Mutirão FUNAPS Comunitário}

0 Programa FUNAPS Comunitário, conforme apresentado acima, foi um braço da política habitacional adotada pela gestão da prefeita Luiza Erundina na cidade de São Paulo entre os anos 1989 e 1992.

A principal diretriz desse Programa foi fortalecer a participação da comunidade organizada em torno da questão habitacional, estimulando a auto-gestão nos empreendimentos financiados pelo município de São Paulo, através do Fundo de Atendimento à População Moradora em Habitação Subnormal - FUNAPS. Promovendo a participação direta da população em todas as etapas de desenvolvimento do processo, do planejamento a construção, o programa pretendia sobretudo "ser um caminho para conscientização do cidadão." ${ }^{3}$

0 Programa foi concebido a partir de três eixos: área das edificações, número de famílias por associação e estrutura de financiamento.

Conforme critérios observados nos estudos do urbanista francês Blacheré, estabeleceu-se a área mínima de $12 \mathrm{~m}^{2}$ por habitante, o que, considerando uma família de 5 membros a ser atendida pelo programa, definiu uma área mínima de $60 \mathrm{~m}^{2}$ por habitação.

\footnotetext{
${ }^{3} U m$ importante trabalho sobre os processos de concepção e construção do programa FUNAPS Comunitário, foi desenvolvido pelo arquiteto Reginaldo Ronconi, então coordenador do programa, ver: RONCONI, 1995.
} 
Quanto ao número de famílias por associação, procurou-se estabelecer uma relação mínima entre esse número e a possibilidade de viabilizar alguma economia de escala. Chegouse ao número de 20 famílias em associação como limite mínimo para acessar o financiamento e 200 famílias como limite máximo.

A estrutura de financiamento foi concebida levando em conta a criação de condições para amenizar o esforço humano e permitir igualdade nas condições de trabalho. Foram previstos, então, recursos para locação de equipamentos e o financiamento foi dividido nos seguintes itens: canteiro de obras, mão-de-obra, acompanhamento técnico e material de construção.

Através da elaboração de orçamentos genéricos, chegou-se ao valor de 900 VRFs por unidade habitacional. Considerando a área mínima determinada de $60 \mathrm{~m}^{2}$ por unidade, foi estabelecido o valor de $15 \mathrm{VRFs} / \mathrm{m}^{2}$.

Os limites de financiamento foram estabelecidos somente para a unidade habitacional. Os recursos para as obras de infra-estrutura e aquisição dos terrenos também sairiam do FUNAPS, mas como esses itens têm maior variação de preço, não foram fixados limites precisos.

\subsubsection{As diretrizes do Programa}

De acordo com os critérios apresentados no item anterior, foram estabelecidas as seguintes diretrizes quanto às associações comunitárias, à assessoria técnica, ao financiamento e quanto aos terrenos ${ }^{4}$.

As associações comunitárias foram definidas como forma de organização da população para enfrentar o problema da falta de moradia. A elas se propôs a realização da construção, assumindo o gerenciamento do empreendimento desde o projeto até a construção das casas, utilizando, inclusive, sua força de trabalho para obter uma habitação mais próxima de suas necessidades reais. Foi definido que a associação comunitária trabalharia em regime de autogestão ficando responsável pela aplicação dos recursos do projeto à obra.

A assessoria técnica deveria ser prestada por entidade sem fins lucrativos e cadastrada na Superintendência de Habitação Popular - HABI. Eram atribuições das assessorias técnicas prestar assistência técnica, jurídica, contábil, administrativa e social, sempre que necessário para garantir o melhor desempenho da associação. A remuneração prevista no convênio seria de, no máximo, 4\% do total do financiamento.

0 financiamento foi viabilizado por $\mathrm{HABI}$, através do Fundo de Auxilio à População Moradora em Habitação Subnormal - FUNAPS, dentro dos critérios de atendimento praticados pelo órgão, mediante aprovação pelo Conselho Deliberativo do FUNAPS de solicitação de

\footnotetext{
${ }^{4}$ As informações apresentadas neste item foram extraídas de: RONCONI, 1995.
} 
financiamento encaminhada pelos escritórios regionais de HABI. 0 pedido de financiamento deveria ser discutido no Fórum Regional de Habitação.

A duração do retorno do financiamento seria de no máximo 12 anos. Os limites de financiamento foram fixados para a realização de 20 (vinte) até 200 (duzentas) unidades habitacionais. Cada unidade poderia absorver o custo máximo de 900 VRFs (não ultrapassando em hipótese alguma o valor de $15 \mathrm{VRFs} / \mathrm{m}^{2}$ ). Desse valor seriam deduzidos todos os custos envolvidos na realização do convênio, inclusive aqueles a fundo perdido.

Os terrenos poderiam ser propriedade da associação, da prefeitura ou ser adquirido com financiamento especial do FUNAPS. Os terrenos pertencentes às associações deveriam ser alienados como garantia hipotecária do financiamento das unidades.

Já nos terrenos pertencentes à prefeitura ou obtidos por financiamento, uma vez concluídas as obras, cada família ocuparia provisoriamente sua casa durante doze meses, assinando o Termo de Ocupação Provisória do FUNAPS, pagando uma taxa equivalente à prestação definitiva, que seria abatida do financiamento. Cumprido este período, o FUNAPS celebraria um contrato de financiamento com cada família que participou do mutirão seguindo as normas do Conselho Deliberativo do FUNAPS, levando em conta a renda e a composição familiar.

\subsubsection{Realizações do FUNAPS Comunitário}

0 Programa Provisão de Moradias - em suas variantes: Produção por Empreiteira, Produção por Mutirão e Cortiços - atendeu um total de 25.835 famílias durante a gestão 19891992; sendo 4.901 as unidades entregues e 20.934 as não concluídas até o fim de 1992. Esse total representou $6,8 \%$ da demanda considerada emergencial pelos parâmetros estabelecidos por HABI. 0 quadro abaixo resume a produção referente ao FUNAPS Comunitário.

Tabela 13 - Empreendimentos HABI - Provisão de Terras e Moradias - UH por Mutirão.

\begin{tabular}{lrrr}
\hline & \multicolumn{2}{c}{$\begin{array}{c}\text { U.H. por mutirão } \\
\text { (familias atendidas) }\end{array}$} & total \\
\hline Leste 1 & concluidas & não concluidas & \\
Leste 2 & 242 & 1.726 & 1.968 \\
Norte & 37 & 3.382 & 3.419 \\
Oeste 1 & 0 & 100 & 100 \\
Oeste 2 & 0 & 1.050 & 1.050 \\
Sudeste & 0 & 1.381 & 1.381 \\
Sul 1 & 0 & 473 & 473 \\
Sul 2 & 293 & 1.132 & 1.425 \\
Total (familias.) & 82 & 621 & 703 \\
\hline
\end{tabular}

Fonte: PMSP, 1992.

A localização e a relação desses empreendimentos é exposta na figura abaixo. 


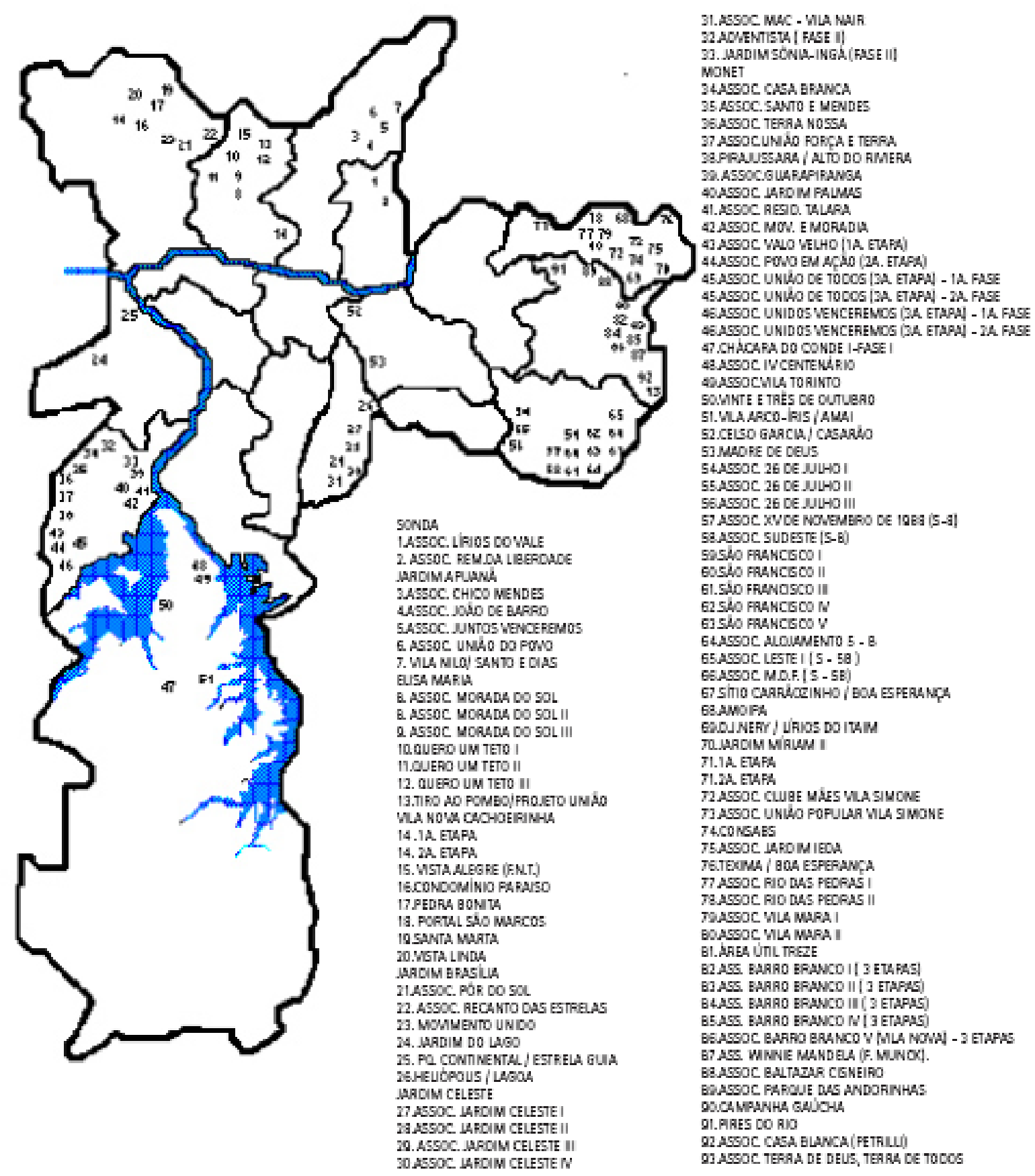

Figura 6 - São Paulo: Localização dos Empreendimentos financiados pelo FUNAPS

Outros resultados considerados relevantes referentes ao processo de produção de moradias proposto pelo programa são descritos a seguir.

\section{- participação social:}

0 desafio colocado na formulação do FUNAPS Comunitário foi transformar a autoconstrução no seu modelo individualizado, amplamente utilizado para a construção das periferias da cidade, em um modelo de produção coletiva de habitação, organizado e gerido pela própria comunidade. Para tanto, foram privilegiadas, como visto nas diretrizes do programa, os segmentos organizados da população de baixa renda. 
Por partir de uma organização que já vinha sendo construida pelos Movimentos de Moradia, os mutirões fortaleceram ainda mais a teia das relações sociais, criando maior proximidade do individuo com a casa e com a vizinhança, o que, dentre outros benefícios, evitaria as recorrentes substituições dos moradores por outros de renda maior.

As discussões de projeto, quando realizadas de forma participativa, parecem abrir caminhos para um crescimento mútuo entre os responsáveis pela elaboração do projeto e aqueles que vão construí-lo e habitá-lo.

\begin{abstract}
A forma de identificar e compreender os problemas mais intuitivamente, como uma caracteristica típica do uso da criatividade acima daquela dos métodos analíticos, tem espaço para emergir nessa organização popular, permitindo que as pessoas que estão apreendendo a ler com 60 anos de idade exercitem com grande competência as atribuições de gerenciamento e direção dos processos extremamente complexos de organização humana (RONCONI, 1995, p.192).
\end{abstract}

\title{
- uso de processos industrializados:
}

A criação de usinas de pré-fabricação propiciou avanços significativos na qualidade das construções além de diminuir o esforço humano empregado. Esse conhecimento, levado pelas assessorias técnicas, foi bem assimilado pelas associações. No mutirão São Francisco, por exemplo, a usina de argamassa armada produziu desde peitoris para as janelas até brises para a proteção da porta de entrada.

A experiência da racionalização do canteiro de obras do FUNAPS Comunitário serviu para aproximar a população de baixa renda de processos como o da pré-fabricação, desmistificando a relação dos mutirões com práticas tecnológicas rudimentares.

- variedade das tipologias adotadas:

A variedade de tipologias foi uma das marcas do FUNAPS Comunitário. 0 fato dos projetos contarem com a mesma disponibilidade de recursos não significou a adoção de uma tipologia padrão. A adoção de várias tipologias não acarretou em maiores custos de mão-deobra, já que a adaptação aos diversos sítios acabou por gerar economia de recursos.

\section{- a questão da propriedade:}

0 Programa propôs a utilização de formas alternativas à propriedade individual da casa ou terreno, como a concessão de direito real e de uso, propriedade coletiva, condominial e cooperativa. Tal fato, além de apontar para outras formas possiveis de tratar a questão da propriedade dentro de um programa habitacional, conseguir fazer com que as pessoas percebessem mais a forma de produção da cidade.

Como a habitabilidade você começa a perceber coisas concretas: a janela; como é que faz ou não faz, economia de material, segurança, qualidade do ambiente, materiais melhores ou piores e dai dessas discussões puxar para o geral, para o que é uma cidade, como ela está se formando, porque as pessoas moram daquela forma, porque elas estão naquela situação, porque uma periferia é daqueles moldes, porque as pessoas moram mal, moram em favelas, cortiços, moram de aluguel e ainda assim, moram mal (RONCONI, 1995, p.200). 
- continuidade:

0 FUNAPS Comunitário tornou-se uma marca da administração petista de 1989 a 1992 e uma das únicas iniciativas dessa gestão que continuou existindo na Prefeitura de São Paulo até hoje, apesar do desmonte dessa política promovido nos anos subseqüentes, como relata Amaral (2001):

Se eliminou as divisões regionais de atendimento, se perseguiu funcionários
experientes, inviabilizando o seu trabalho, [se] desmontou equipes técnicas e
mecanismos de controle. Cerca de 120 empreendimentos foram paralisados e se
deterioraram, acarretando um criminoso desperdício de recursos públicos. Foram
interrompidos os programas de cortiços e de assistência jurídica. As favelas se
multiplicaram e foram cortados os canais de diálogo com os movimentos de moradias.
Os moradores de alojamentos provisórios lá permaneceram, em situação
extremamente precária. A falta de uma política de habitação, no periodo, contribuiu
para que as condições de vida de um número significativo de pessoas se deteriorassem.

\subsubsection{Os Custos do FUNAPS Comunitário}

Para buscar a redução de custos das unidades habitacionais, sem que isso ocasionasse a diminuição da área útil mínima estabelecida nas diretrizes do programa, foram propostas pelo Departamento de Parcelamento do Solo e Intervenções Urbanas - PARSOLO algumas medidas como a redução do tamanho dos lotes destinados à habitação unifamiliar, a redução no porte do sistema viário, o aumento dos coeficientes de aproveitamento, a maior variedade de tipologias urbanísticas; a redução de vagas para estacionamento e um maior controle de terraplenagem e execução de infra-estrutura ligados à drenagem e estabilidade. (RONCONI, 1995, p.14).

Os custos médios praticados pelo Programa durante a gestão 1989/1992 são descritos na tabela abaixo.

Tabela 14 - Índices de custos médios praticados pelas obras de infraestrutura por empreiteira + edificação por mutirão

\begin{tabular}{lr}
\hline item & custo \\
\hline área urbanizada (US\$/m²) & 14,79 \\
infra-estrutura (US\$/UH) & $2.196,08$ \\
edificações (US\$ $/ \mathrm{UH})$ & $5.985,31$ \\
edificações (US\$/m²) & 98,59 \\
área edificada $\left(\mathrm{m}^{2} / \mathrm{UH}\right)$ & 61,89 \\
área urbanizada $\left(\mathrm{m}^{2} / \mathrm{UH}\right)$ & 228,09 \\
\hline
\end{tabular}

Fonte: PMSP, 1992.

Para Bonduki (2000), o barateamento da casa produzida por autogestão é garantido não apenas pelo trabalho gratuito do mutirão, mas também pela inexistência de Benefícios de Despesas Indiretas - BDI. A compra de materiais por um bom preço, a criação de centrais de produção de componentes pré-fabricados, entre outros fatores garantiram um custo $50 \%$ inferior ao cobrado pelas empreiteiras. 


\subsection{Projeto Cingapura 1993-2000}

\subsubsection{Cenário existente para a concepção do Programa}

Em 1990, Fernando Affonso Collor de Mello assumiu a presidência do Brasil. Seu governo foi marcado por medidas drásticas como o Plano Collor, que bloqueou a poupança dos brasileiros, a abertura do mercado nacional e a diminuição da "reserva de mercado". Cortando gastos públicos de forma indiscriminada, aumentando a abertura da economia e tentando controlar a inflação de forma drástica, o governo enfatizou mais ainda a tendência neo-liberal para a qual o país já vinha pendendo desde o governo anterior.

Assim, entre 1990 e 1992, assistiu-se a um movimento de queda da produção, acompanhado de desemprego. 0 emprego reduziu-se em 7.9\% no período, o PIB per capita em $2.5 \%$ e o salário mínimo em $9.1 \%$, ao passo que as importações aumentaram 4,3\% (TASCHNER, 1997, p.48). Com relação à habitação, o governo Collor fez pouco. A política habitacional do período ficou vinculada ao Ministério de Ação Social, onde, em maio de 1990, foi lançado o Plano de Ação Imediata para Habitação - PAlH que, segundo Azevedo (1996, p.73-101), ficou longe de cumprir as várias metas estabelecidas.

Nesse panorama, os municípios e estados foram pressionados pelo aumento dos assentamentos informais, invasões e ocupações. No município de São Paulo, a taxa de crescimento da população favelada entre 1987 e 1993 foi de 16,6\% anuais, o que elevou a população favelada para 2 milhões de pessoas (TASCHNER, 1997, p.51). Esse incremento da população favelada, a exemplo da década de 70, se deu mais uma vez pela expulsão da população mais pobre das áreas valorizadas da cidade, com o uso do dinheiro público. Mais uma vez este foi o "preço do progresso" necessário para entrar na "era da globalização", como explica Ferreira:

\footnotetext{
Assim, também no âmbito das cidades, o discurso da "globalização" serve para vender uma imagem supostamente "necessária" de modernização, enquanto que na verdade se acentuam ainda mais os desequilibrios na alocação dos investimentos públicos urbanos, gerando diferenciações e valorização fundiárias ainda mais abruptas (FERREIRA, 2005).
}

Em 1993, o Plano Real instituiu a décima moeda brasileira (que levou o mesmo nome do Plano) para tentar conter uma inflação recorde de $2.708,5 \%$ ao ano. No que diz respeito à inflação, o plano foi um sucesso, em 1996, o esse índice chegou a 11\% ao ano (TASCHNER, 1997, p.52). Com pouco dinheiro para investimentos devido ao enxugamento necessário no processo de estabilização, pouco se fez em habitação em nível federal. 0 processo de descentralização das políticas públicas de habitação que já vinham em curso desde a década de 80 se intensifica.

A busca de recursos financeiros levou o Estado de São Paulo a aprovar a lei que amplia em 1\% a arrecadação do ICMS e a destina exclusivamente para a construção de moradias. Entre 1990 e 1994, o governo arrecadou US\$ 1.293.900.000, com o que construí mais de 80.000 unidades (TASCHNER, 1997, p.53). 
Foi nesse cenário - no qual estados e municípios tomaram a iniciativa de procurar suas próprias fontes de financiamento de moradias - que, em 1993, iniciou-se o Projeto Cingapura.

\subsubsection{0 desmonte dos mutirões e a instalação do Projeto Cingapura na década de 90}

Eleito em 1993, o prefeito Paulo Salim Maluf encontrou a estrutura burocrática da Secretaria Municipal de Habitação montada para viabilizar a produção de moradias em regime de mutirão. Como exposto no quadro referente à produção do FUNAPS Comunitário, ao final da gestão Luiza Erundina em 1992, havia mais de 10.000 unidades habitacionais em fase de viabilização, com contratos de liberação de recursos assinados.

No contexto apontado de desemprego crônico e aumento da população favelada, a equipe de governo de Paulo Maluf produziu um programa habitacional que seria a "o carrochefe" daquela administração.

Assim foi criado o Projeto Cingapura que, segundo a prefeitura, tinha como objetivo a urbanização definitiva de favelas e de áreas degradadas, com a construção de prédios de apartamentos, urbanização dos lotes a serem preservados e relocação das habitações e lotes remanescentes para atendimento das diretrizes do projeto global de cada área com eliminação das áreas de risco, transformando as favelas em verdadeiros bairros.

A meta era atender 92.000 famílias através da urbanização e verticalização de favelas e de áreas degradadas, tendo como premissa a manutenção das familias objeto da intervenção no mesmo local da atual moradia. Para colocar esse programa em prática foi nomeado como secretário da habitação o empresário Lair Krahenbuhl, representante do Sindicato da Habitação do Estado de São Paulo - SECOVI-SP e da Câmara Brasileira da Industria da Construção - CBIC, ambos órgãos ligados à indústria da construção civil em São Paulo.

No primeiro dia à frente da secretaria, Krahenbuhl já tinha em mãos um projeto para a construção de 20 mil unidades habitacionais, entre apartamentos e lotes urbanizados (REVISTA CONSTRUÇÃO, agosto de 1993).

Segundo Silva (2003), com a nomeação deste empresário representante dos agentes privados dos setores da construção civil, o diálogo entre poder executivo e os movimentos sociais que defendiam o direito à moradia ficou mais difícil, uma vez que este empresário foi indicado para a pasta da Secretaria da Habitação para acelerar as obras de verticalização de favelas construídas por empreiteiras.

Diante deste quadro, a União dos Movimentos de Moradia - UMM se articulou e realizou atos públicos exigindo o repasse dos recursos para os mutirões em andamento. Cartas endereçadas ao Secretário de Habitação, reforçavam esse pedido:

Prezado Senhor, ...em 04 de agosto do presente ano, durante audiência com V. Exa., nos era comunicado que em 30 dias seriam definidas as propostas de atuação desta gestão, bem como a forma de cumprir os compromissos assumidos pelo Exmo Prefeito. Dessa maneira desejamos obter respostas até o final de setembro...diante do processo 
de centralização de $\mathrm{HABI}$ reivindicamos a continuidade, de modo eficaz e rápido, do acompanhamento de todos os programas em andamento. ${ }^{5}$

Segundo Amaral, "ao levantar suspeitas sobre a lisura dos convênios e sobre a gestão das entidades, que incluiu campanha pública em jornais e televisão, essa [atual] gestão estava também paralisando o programa que mais consumia recursos do FUNAPS e que exigiria investimentos públicos para a conclusão das cerca de 7 mil unidades em andamento. A SEHAB modificou a sistemática de apresentação de todos os gastos e exigiu retroatividade, obrigando as associações a gastarem enorme tempo e trabalho para provar que estavam totalmente em ordem" (ROSSETO, 2003).

Apesar de divulgar o contrário, como mostra o folheto abaixo, a Prefeitura de São Paulo não cedeu à pressão dos Movimentos de Moradia e paralisou as obras dos mutirões iniciados na gestão anterior ${ }^{6}$. O FUNAPS foi extinto no ano de 1994 e as verbas destinadas à habitação foram concentradas no Projeto Cingapura.

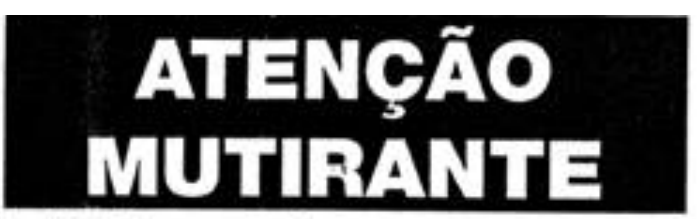

Nenhum mutirão está parado! Nenhum mutirāo será paralisado !

Essa é a verdade. Não acredite nos mentirosos que querem usar você para seus objetivos politicos. Vocé sabia que tem gente que nunca entrou num mutirāo e está nesse movimento ?

Eles querem prejudicar seu mutirão para poder atacar a Administração Municipal.

E ainda, juram que estäo do seu lado.

Não entre na onda deles.

Cerca de 20 mutirōes estão com irregularidade na prestação de contas. Apesar disso, para a construção das casas continuar, a Prefeitura liberou verba também para esses mutirōes.

Vire este folheto e veja na relação do verso quanto seu mutirão está recebendo de dinheiro novo para a construção da sua casa.

Superintendência de Habitaçầ

Popular - HABI

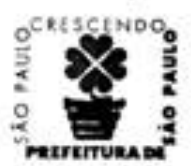

Valores que estão sendo liberados pela Prefeitura para continuidade das obras.

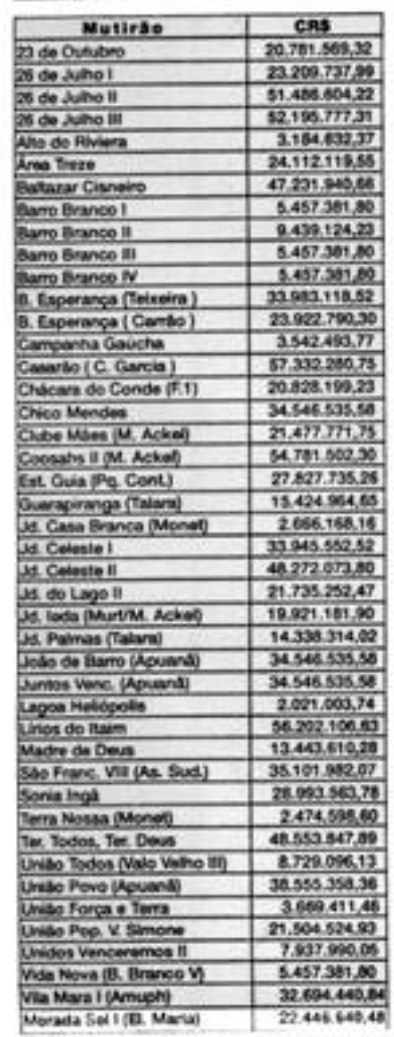

Figura 7 - Folheto PMSP sobre mutirões

\footnotetext{
${ }^{5}$ Trecho da carta encaminhada pela União dos Movimentos de Moradia ao Secretário Municipal de Habitação em 03 de setembro de 1993

${ }^{6}$ Nesse período foi solicitado ao Tribunal de contas do Município um levantamento sobre a prestação de contas dos mutirões, o que paralisou totalmente o repasse de verba para os mesmos.
} 


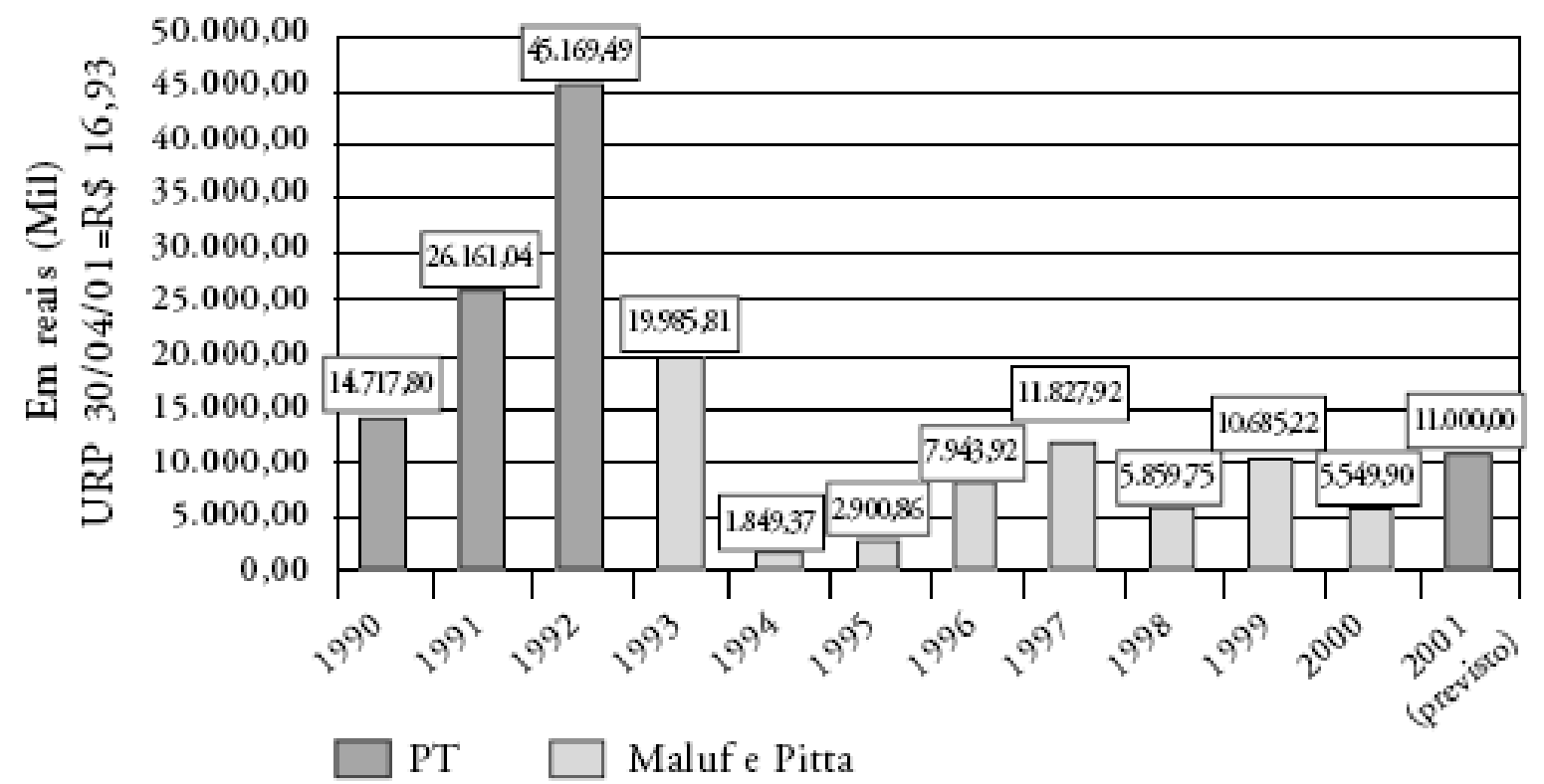

Fonte: Elaborado pelo gabinete do vereador José Eduardo Martins Cardoso, 2000, e atualizado pelo gabinete do vereador Nabil Bonduki, 2001. Diários oficia is do município de SP.

Nota: URP = valor de referência informado pela CEF, que equivale a UPF, referência padrão dos convênios assinados de 91 a 93, que deixou de ser calculada pelo Banco Central em agosto de 1994.

Figura 8 - Liberação de Verbas por SEHAB e COHAB 1990-2001

0 quadro apresentado acima, refere-se à liberação de recursos para os mutirões e ilustra a prioridade do programa nas diferentes gestões da prefeitura. De acordo com Amaral (2002), "mostra como se conseguiu retomar as liberações de parcelas para os mutirões nas gestões malufistas, a partir da luta dos movimentos, mesmo que de forma descontínua e desacelerada."

No segundo semestre de 1993, com o intuito de embasar a nova política habitacional, foi solicitado à Fundação Instituto de Pesquisas Econômicas - FIPE, um estudo sobre as características das favelas no município englobando o dimensionamento, condições de habitabilidade e dados socioeconômicos da população favelada, entre outras informações.

Verificou-se a tendência de substituição dos barracos de madeira por alvenaria, o que demonstrou uma tendência de permanência na favela e foi estimada uma população favelada de 1.901 .982 indivíduos, o que significava, então, 19\% da população. Quanto à renda média dos chefes de família, em sua maioria naturais de outros Estados (60,8\%), foi diagnosticado que 42,3\% dos chefes de família em 1993 tinham renda mensal até 3 salários mínimos.

Para fazer frente a esse quadro, a prefeitura apresentou em 1993 o Projeto Cingapura, Programa de Verticalização de Favelas - PROVER cuja principal característica foi manter a população favelada no próprio local. 


\subsubsection{As diretrizes gerais da politica habitacional nas gestões 1993-1996 e 1997-2000}

Através de um suplemento publicado em 5 de janeiro de 1995 no Diário Oficial do município, a Prefeitura Municipal de São Paulo apresentou as diretrizes da política habitacional a ser adotada, fortemente ancorada no relatório elaborado pela FIPE.

Segundo esta publicação, o erro estratégico das políticas habitacionais anteriores foi desconsiderar, "em decorrência da lei de mercado, que o imóvel tem um valor comercial, por isso é vendido sempre que alguma outra necessidade for prioritária à posse da habitação, também foram desconsiderados as variações salariais dentro dos prazos de financiamento" (SILVA, 2003, p.46). Assim, a política habitacional proposta previa a concessão de subsídios às famílias de mais baixa renda através de instrumentos que garantissem às famílias beneficiárias a segurança legal e necessária da propriedade da unidade habitacional e o retorno dos investimentos às fontes financiadoras.

As diretrizes gerais dessa política são descritas a seguir:

a - Concentração de todos os recursos do município direcionados aos programas habitacionais em um único fundo.

b - Democratização e transparência dos procedimentos e processos decisórios, com maior controle e destinação dos recursos do fundo através da criação do Conselho Municipal de Habitação.

c - Criação de um cadastro único dos pretendentes e beneficiários dos financiamentos habitacionais de todos os programas habitacionais, em especial os concedidos pelo Fundo Municipal de Habitação.

d - Estabelecimento de critérios públicos de seleção de famílias, quer de forma individual quer via associações.

e - Incentivo à iniciativa privada no sentido de promover programas habitacionais complementares.

f - Estimular a pesquisa e o desenvolvimento tecnológico objetivando novas técnicas de produção de moradia.

g - Isenção de criação dos Grupos de Assessoria e Participação - GAPs.

h - Priorização do acesso à habitação para população de baixa renda.

i - Emprego de formas alternativas de produção e acesso à moradia, incluindo:

j - Alternativa de "leasing" (locação com opção de compra), locação social, além da comercialização convencional (venda das unidades). 
k - Financiamento individual ou em condomínio para construção por mutirão / autoconstrução ou aquisição de casa pronta no mercado.

I - Estabelecimento de uma política de subsídios de caráter pessoal.

m - Redução dos custos de produção e comercialização das habitações.

n - Comercialização das unidades habitacionais com instrumentos que juridicamente garantam, de fato, o direito à propriedade adquirida, dando a segurança necessária às famílias de todos os programas habitacionais.

o - Atuação da Secretaria da Habitação em parceria com a iniciativa privada, constituindo empresa de capital misto, em que se antecipam os recursos financeiros através da emissão de debêntures, ou pelo aporte de recursos das próprias empresas privadas. Incluem-se, também nesse contexto, as Operações Interligadas.

Ainda segundo o conteúdo da publicação mencionada, foram definidas as seguintes diretrizes pertinentes ao Projeto Cingapura:

Seleção e classificação: serão formulados critérios de seleção de acordo com os programas a serem promovidos; feita a divulgação pública dos critérios de seleção, classificação e definição das faixas de renda a serem atendidas, tipologia das habitações, valores de comercialização ou locação, entre outros, para a orientação da população.

Aprovação e regularização dos empreendimentos habitacionais: será formulado um programa de regularização no sentido de permitir a legalização dos empreendimentos promovidos pela $\mathrm{HABI}$, viabilizando a transferência à COHAB. Serão priorizados os empreendimentos produzidos pela COHAB. Serão regularizados os terrenos que se encontram em "estoque" de $\mathrm{HABI}$ ou $\mathrm{COHAB}$, além da aprovação dos projetos habitacionais que deverá ter caráter preferencial e prioritário, com redução dos prazos e eliminação dos custos e preços públicos.

Sistemas de financiamento: serão elaboradas normas e procedimentos para 0 financiamento, com recursos do Fundo Municipal de Habitação e serão elaboradas normas para a aplicação dos recursos originários.

Comercialização e outras formas de ocupação e controle: serão definidas as condições socioeconômicas das famílias a serem atendidas, de modo que se identifique as que terão acesso à compra, as que serão atendidas por locação com opção de compra ou outras modalidades de ocupação. Todas as atividades dos programas habitacionais e complementares serão controladas e acompanhadas através de relatórios gerenciais e estatísticos, que terão seus resultados divulgados para o Conselho do Fundo Municipal de Habitação e demais órgãos e entidades interessadas. 
Execução das obras físicas: serão definidas as formas de execução das obras de acordo com as diversas modalidades de programas oferecidos; serão definidos a partir de $\mathrm{HABI}$ as diversas formas de integração da execução das obras habitacionais com as de infra-estrutura básica e equipamentos urbanos e sociais; serão implementados procedimentos de controle de um Programa de Qualidade para Projetos, Obras e Serviços Habitacionais; todas as contratações de obras e serviços deverão atender às exigências do Código de Defesa do Consumidor; serão incentivadas todas as iniciativas de desenvolvimento tecnológico de sistemas construtivos habitacionais; será garantida a infra-estrutura básica e equipamentos urbanos básicos e serão estabelecidos ainda, os procedimentos de apropriação de custos e os eventuais repasses aos beneficiários finais.

Subsídios: o valor máximo de subsidio a ser concedido foi definido em 50\% do valor do encargo mensal da unidade habitacional mínima. Para financiamentos com valores superiores aos da unidade básica, o valor do subsidio será decrescente em termos reais. Fica para o futuro a definição das normas e procedimentos, para o acompanhamento das famílias subsidiadas que incluirá a definição da periodicidade de aferição da necessidade do subsídio e para uma manutenção.

Favelas: será priorizada a manutenção das famílias no próprio local da favela, através de projetos de urbanização e verticalização das favelas ou, se inviável, promover programas habitacionais no sentido de manter as familias na mesma região onde está situada a favela.

\subsubsection{Projeto Cingapura}

Em 1993, foram iniciadas as obras de implantação do Projeto Cingapura ou Programa de Verticalização de Favelas - PROVER, cuja a meta era atender 92 mil famílias em 72 meses através da construção de 30 mil unidades habitacionais, atingindo no total 243 núcleos de favelas.

0 nome "Projeto Cingapura" foi dado pelo publicitário Duda Mendonça que conheceu a história de Cingapura e deu a idéia para que o projeto levasse o nome da ilha.

Por ter participado do batismo do projeto, me sinto uma espécie de padrinho do Projeto Cingapura. É muito gostoso participar de um projeto desde o início, vê-lo dar certo e ficar famoso (KRAHENBUHL, 1996).

Segundo Krahenbuhl (1996), o critério para escolha das favelas a serem atendidas foram os seguintes:

- Favelas localizadas em áreas públicas;

- Favelas com maior nivel de adensamento por $\mathrm{m}^{2}$;

- Locais onde os habitantes já haviam consolidado sua ocupação;

- Onde havia grande número de barracos em áreas de risco; 
- Possibilidade de integração com a vizinhança;

- Não constituiam obstáculos para a execução de alguma obra pública;

- Possibilidade de atendimento da infra-estrutura.

Porém, é possivel perceber uma tendência acentuada de escolha de terrenos em favelas que estavam próximas às vias de grande circulação da cidade. Dos 17 primeiros projetos executados, 12 localizavam-se próximos a grandes avenidas.

Quanto às tipologias adotadas, foi estabelecido um projeto padrão de 5 pavimentos tipo "H" predominante que definiu a "cara" do Programa, como mostra a figura abaixo.
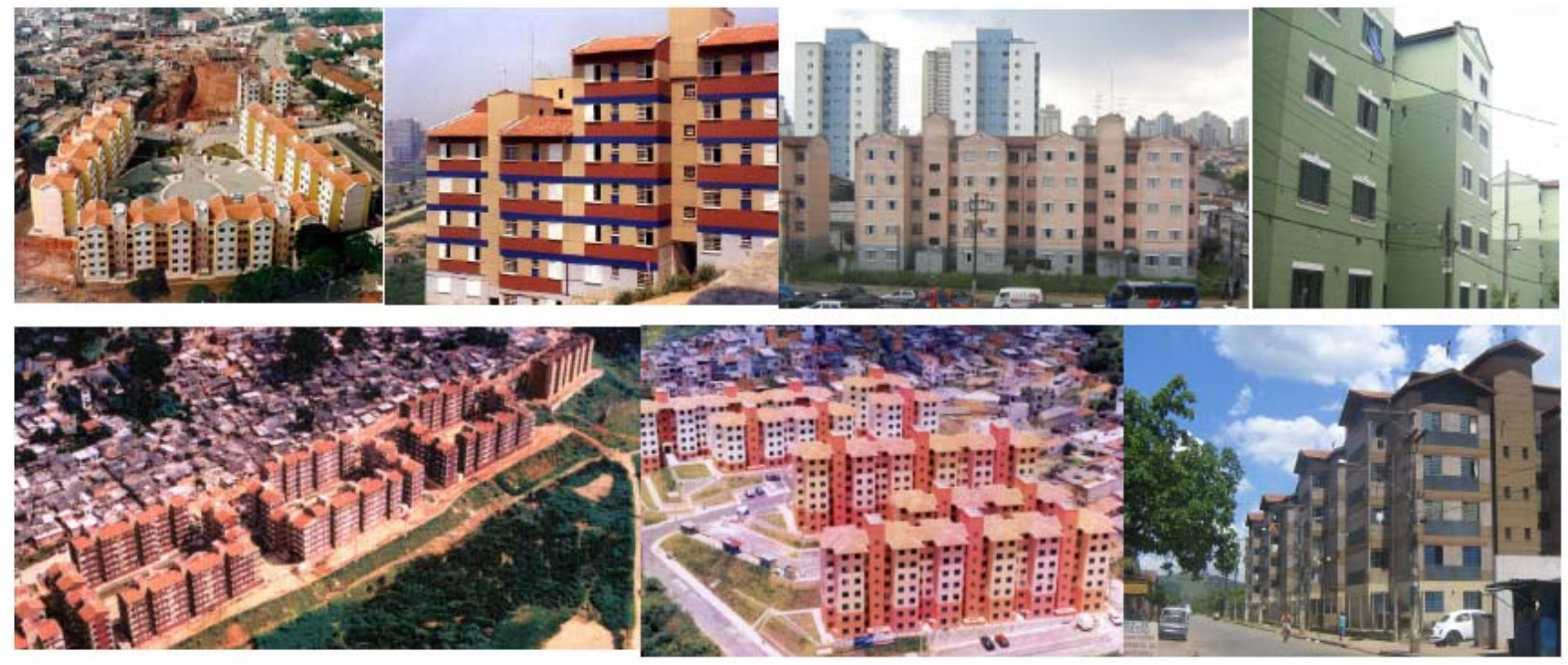

Figura 9 - Mosaico Cingapura (fonte: COHAB)

Também foram utilizados, em uma fase posterior, edifícios de 7 e 10 andares com elevador conforme ilustração.

Quanto aos apartamentos foram utilizadas 3 tipologias básicas:

- apartamentos com 1 dormitório - área de $37.27 m^{2}$

- apartamentos com 2 dormitórios - área de 43,36 m²

- apartamentos com 3 dormitórios - área de 51,37 m²

Eleita a área, o esquema de intervenção na favela começava com o cadastramento das familias por parte de uma equipe da prefeitura. Em seguida, essas familias eram removidas para um alojamento provisório, construído preferencialmente próximo à favela, onde aguardavam a conclusão das obras para então se mudarem para os apartamentos.

Segundo relata Beth ${ }^{7}$, assistente social que acompanha a comunidade da Zaki Narchi desde o início do projeto, em 1994, a primeira etapa - em qualquer unidade, em qualquer fase -

\footnotetext{
${ }^{7}$ Entrevista concedida a Tchê Costa, Viviam Dozono e José Marcos Rocha em 03/06/2002, publicada no sítio: www.midiaindependente.org; acessado em 10/10/2003.
} 
era o cadastramento das famílias, pois "só as famílias que fossem da comunidade naquela época receberiam apartamentos".

Em seguida, a construtora da unidade erguia um alojamento coletivo. Era de concreto fino, pré- moldado, com um banheiro para cada dez famílias. É uma fase muito complicada, relata. Muitas famílias resistem a serem transferidas para os alojamentos, móveis são perdidos na mudança e a organização e equilibrio da comunidade começou a ser quebrada já neste ponto. Famílias de fora montam barracos e invadem os alojamentos desocupados na esperança de conseguir também um apartamento. "Mas não podíamos atender a todos que chegavam; só haveria apartamentos para quem estivesse cadastrado". Os recém chegados não se conformavam e os assistentes sociais contam relatos de ameaças de morte.

Nesta fase também começavam as palestras e orientações de como morar num prédio, com orientações sobre barulho, lixo - que, nos barracos, é jogado diretamente pela janela - e manutenção do apartamento. "Há gente que não se habitua a morar em apartamentos. Na unidade Bela Vista, atendemos um prédio que tinha todas as privadas entupidas", relata Beth.

A organização dos blocos também é orientada antes da ocupação. As unidades devem ter um síndico por bloco, que recebe o condomínio e faz o intermédio com a prefeitura. Após a ocupação, a prefeitura presta a "assistência pós-ocupação". 0 projeto prevê esse serviço, realizado por assistentes sociais até 2007, ano da emancipação de todas as unidades e início do pagamento da dívida com o BID.

Em 1994, como parte do processo de adaptação do legislativo à política habitacional proposta para o município, foi aprovada a lei no. 11.632, que extinguiu o FUNAPS e repassou os seus ativos financeiros para o novo Fundo Municipal de Habitação - FMH. Esse Fundo foi de importância estratégica para implantação da política habitacional proposta pois, através da criação Conselho do Fundo Municipal de Habitação, onde 60\% dos seus membros eram compostos por indicações do poder executivo, centralizaram-se no poder público municipal as principais decisões referentes aos recursos públicos para a habitação. Segundo Silva (2003, p.46), esta lei desfez a estrutura participativa que a gestão Erundina montou, quando assinou o decreto 29.947, pois aquele realmente definia a participação popular na Política Habitacional via Conselhos Regionais e Conselhos por Problemas Específicos.

No entanto, a maior parte dos recursos do Cingapura foi proveniente de operações de crédito internacionais com o Banco Interamericano de Desenvolvimento - BID e de recursos da Caixa Econômica Federal. Além desses, começaram a chegar recursos de operação assinada anteriormente referente ao programa Guarapiranga (ROSSETO, 2003).

Foram estes recursos externos os principais financiadores do Projeto Cingapura durante as duas gestões Maluf e Pitta, disponibilizados diretamente no Gabinete do Secretário de Habitação. Em 1996, conforme publicação no Diário Oficial da União em 28 de junho, 0 
governo federal, não só autorizou como também concedeu garantias ao empréstimo feito pela Prefeitura Municipal de São Paulo no Banco Interamericano de Desenvolvimento BID.

Autoriza a prefeitura municipal de São Paulo a contratar operação de credito externo junto ao Banco Interamericano de Desenvolvimento - BID, no valor de us\$ 150,000,000.00 (cento e cinqüenta milhões de dólares norte-americanos), destinados a implementação do programa de urbanização e verticalização de favelas PROVER/CINGAPURA; e autoriza a República Federativa do Brasil a conceder garantia referente a mesma operação (DOU, 28/06/1996).

0 contrato celebrado entre o BID e a SEHAB foi para financiar parte do programa habitacional PROVER, precisamente as fases 2 e 4 do programa. A meta definida pelo BID foi: "Melhorar a qualidade de vida de 11.000 famílias que vivem em favelas no município de São Paulo, resgatando a cidadania e melhorando o seu modo de vida."

Uma característica marcante dos governos Maluf e Pitta foi privilegiar a relação com grandes empreiteiras. No lugar de licitar obra por obra, cujo valor de referência seria necessariamente mais baixo e, em conseqüência, permitiria maior participação de empresas de médio porte, eram feitas poucas licitações, agregando várias favelas (lotes de licitação). 0 resultado dessa ação foi a constituição de consórcios de 54 empresas para participarem em pé de igualdade com grandes empresas do ramo da construção civil especializadas em obras públicas, como Camargo Corrêa, OAS e CBPO, vencedoras de vários lotes de licitação (ROSSETO, 2003, p.54).

\subsubsection{Realizações do Projeto Cingapura}

A tabela abaixo apresenta as favelas alvos de intervenção dentro do Projeto Cingapura, dentro das suas respectivas fases e as empreiteiras responsáveis por cada projeto. Verifica-se que as mais de 19.000 unidades habitacionais produzidas dentro do programa ficaram a cargo de dez grandes construtoras.

Tabela 15 - Realizações do Projeto Cingapura

\begin{tabular}{|c|c|c|c|c|}
\hline Programa & fase & lote & Empreendimento & empreiteira \\
\hline PROVER & 1 & 1 & Benfica & SCHAHIN \\
\hline PROVER & 1 & 1 & $\begin{array}{l}\text { Parque Novo Mundo - Nova Tietê } \\
\text { Favela Funeraria } \\
\text { Favela Beibinha } \\
\text { Favela Charco }\end{array}$ & SCHAHIN \\
\hline PROVER & 1 & 1 & Parque Novo Mundo - Vila Maria & SCHAHIN \\
\hline PROVER & 1 & 1 & Zaki Narchi & SCHAHIN \\
\hline PROVER & 1 & 2 & Água Branca & OAS \\
\hline PROVER & 1 & 2 & Jardim Maninos & OAS \\
\hline PROVER & 1 & 2 & Nova Jaguare & OAS \\
\hline PROVER & 1 & 2 & Real Parque/Luiz De Bragança I & OAS \\
\hline PROVER & 1 & 3 & Autodromo & SCHAHIN \\
\hline PROVER & 1 & 3 & Campo Grande & SCHAHIN \\
\hline PROVER & 1 & 3 & Imigrantes & SCHAHIN \\
\hline PROVER & 1 & 3 & Miguel Stéfano & SCHAHIN \\
\hline PROVER & 1 & 3 & Santo Antonio / Peinha & SCHAHIN \\
\hline PROVER & 2 & 1 & Dom Macario & CONSTRUBASE \\
\hline
\end{tabular}




\begin{tabular}{|c|c|c|c|c|}
\hline PROVER & 2 & 1 & Santo Antõnio / Parque Otero & CONSTRUBASE \\
\hline PROVER & 2 & 2 & Heliópolis Gleba L & CBPO \\
\hline PROVER & 2 & 2 & JOSÉ PAULINO DOS SANTO 1ª. ETAPA & CBPO \\
\hline PROVER & 2 & 3 & Chaparral & CAMARGO CORREA \\
\hline PROVER & 2 & 3 & Chaparral / Tiquatira & CAMARGO CORREA \\
\hline PROVER & 2 & 3 & Edu Chaves & CAMARGO CORREA \\
\hline PROVER & 2 & 3 & Edu Chaves / Vila Nilo & CAMARGO CORREA \\
\hline PROVER & 2 & 3 & Haia Do Carrão & CAMARGO CORREA \\
\hline PROVER & 2 & 4 & Jardim Vera Cruz - Urbanização & CONSTRUBASE \\
\hline PROVER & 2 & 4 & $\begin{array}{l}\text { S. Francisco I / V. Cruz - Morro Das Pedras } \\
\text { S. Francisco li / V. Cruz - Cachoeira } \\
\text { S. Francisco lii / V. Cruz - Coruja Do Campo } \\
\text { S. Francisco Vi / V. Cruz - Hidrosfera } \\
\text { S. Francisco V/ V. Cruz - Área } 5\end{array}$ & CONSTRUBASE \\
\hline PROVER & 2 & 4 & Maria Cursi - Urbanização & CONSTRUBASE \\
\hline PROVER & 2 & 4 & Raul Seixas & CONSTRUBASE \\
\hline PROVER & 2 & 5 & São Jorge / Arpoador & OAS \\
\hline PROVER & 2 & 5 & Uirapuru & OAS \\
\hline PROVER & 3 & 3 & Jardim Do Lago & OAS/CORREA/CONSTRUBASE \\
\hline PROVER & 3 & 3 & Real Parque / Luiz Bragança & OAS/CORREA/CONSTRUBASE \\
\hline PROVER & 3 & 4 & Lidiane / Sampaio Correa - Urbanização & PLANOVA \\
\hline PROVER & 3 & 4 & Lidiane - Vila Nova & PLANOVA \\
\hline PROVER & 3 & 4 & Lidiane II & PLANOVA \\
\hline PROVER & 3 & 4 & Piqueri - Urbanização & PLANOVA \\
\hline PROVER & 3 & 4 & Piqueri & PLANOVA \\
\hline PROVER & 3 & 4 & Samarita & PLANOVA \\
\hline PROVER & 3 & 4 & Trivelato & PLANOVA \\
\hline PROVER & 3 & 5 & Chacara Bela Vista & CBPO/SCHAHIN/CONSTRAN \\
\hline PROVER & 3 & 6 & A. E. Carvalho / S. Francisco & H. GUEDES/L.CASTELO/BLOKOS \\
\hline PROVER & 3 & 6 & Goiti & H. GUEDES/L.CASTELO/BLOKOS \\
\hline PROVER & 3 & 6 & Maraial & H. GUEDES/L.CASTELO/BLOKOS \\
\hline PROVER & 4 & 1 & Heliopolis & OAS/CONSTRUBASE \\
\hline PROVER & 4 & 1 & Jose Paulino Dos Santos & OAS/CONSTRUBASE \\
\hline PROVER & 4 & 1 & Jd. Imperador & OAS/CONSTRUBASE \\
\hline PROVER & 4 & 2 & Nicaragua / Vila Da Paz & SANTA BARBARA \\
\hline PROVER & 4 & 3 & Madeirit / Votorantim & H. GUEDES/L.CASTELO/BLOKOS \\
\hline PROVER & 4 & 3 & Pq. Continental & H. GUEDES/L.CASTELO/BLOKOS \\
\hline PROVER & 4 & 3 & São Domingos / Camarazal & H. GUEDES/L.CASTELO/BLOKOS \\
\hline PROVER & 4 & 4 & Morro Da Esperança & CBPO/SCHAHIN/Q. GALVÃO \\
\hline PROVER & 4 & 4 & Sucupira & CBPO/SCHAHIN/Q. GALVÃO \\
\hline PROVER & 4 & 4 & Jd. Guapira li & CBPO/SCHAHIN/Q. GALVÃO \\
\hline PROVER & 4 & 4 & City Jaraguá Setor 3 - Embriões & CBPO/SCHAHIN/Q. GALVÃO \\
\hline
\end{tabular}

Entre 1993 e 2000 foram concluídas 13.456 unidades habitacionais dentro do Projeto Cingapura, distribuídos por região segundo a tabela abaixo.

Tabela 16 - Realizações do Projeto Cingapura por Região de São Paulo

\begin{tabular}{lc}
\hline Região & Número de Empreendimentos \\
\hline Centro & 05 \\
Leste & 20 \\
Norte & 22 \\
Sudeste & 11 \\
Sul & 17 \\
Total & 75 \\
\hline
\end{tabular}

Fonte: $\mathrm{HABI}, 2001$. 


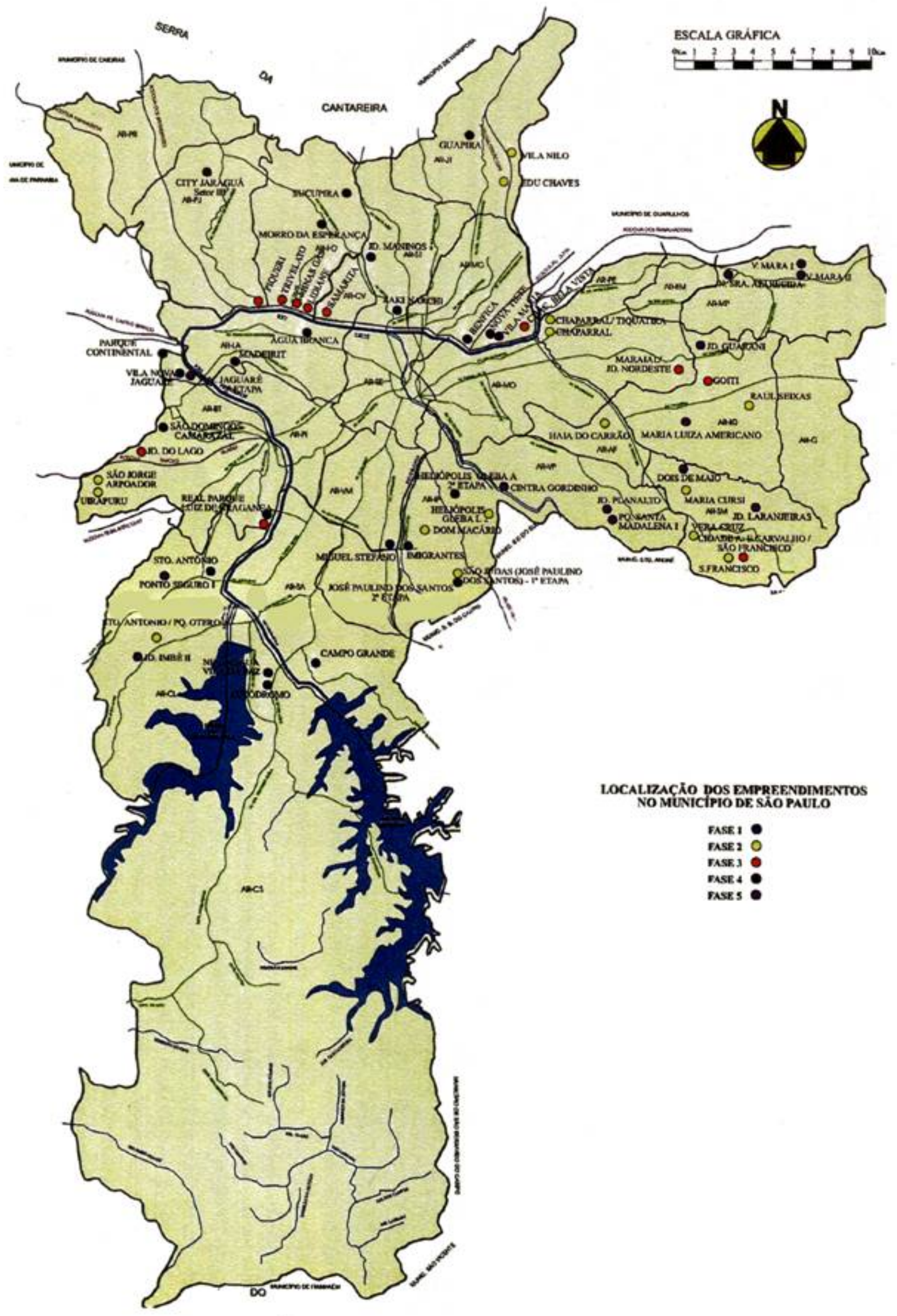

Figura 10 - São Paulo: Localização dos Empreendimentos Cingapura (fonte: SEHAB) 
No relatório de monitoramento realizado pelo Instituto Via Pública, como parte da obrigação da prefeitura em prestar contas com o BID das fases II e IV do PROVER, a alta taxa de inadimplência (66\%) chama a atenção. Segundo o mesmo relatório, a renda familiar é elemento central para explicar tais porcentagens, pois a renda média dos adimplentes é elevada em relação aos inadimplentes.

Tabela 17 - Índice de mora nos pagamentos: rendimento médio familiar total, segundo inadimplência

\begin{tabular}{lrrrr}
\hline & Fase II & Fase IV & City Jaraguá & Total \\
\hline Total & 456,52 & 566,12 & 383,54 & 500,55 \\
Inadimplente & 412,56 & 496,76 & 335,50 & 435,99 \\
Adimplente & 607,87 & 636,85 & 522,16 & 622,32 \\
$\%$ inadimplente & 77,2 & 50,4 & 74,3 & 65,1 \\
\hline
\end{tabular}

Fonte: Relatório BID, 2001.

Um fato curioso apontado ainda neste relatório, é que, ao se comparar as situações ocupacionais dos chefes de família, observa-se que há mais empregados assalariados entre os não pagadores $(43,8 \%)$ que entre os pagadores $(30,2 \%)$. Também há mais pagadores entre os autônomos e biqueiros $(26,5 \%)$ que entre os não pagadores $(20,3 \%)$ autônomos e biqueiros. ${ }^{8}$

Entre as exigências do BID, há o Plano de Ação Social, através do qual foi realizada consulta às populações moradoras dos locais alvo, no sentido de contemplar suas necessidades e anseios e, concluir as ações do programa com a entrega dos títulos de propriedade, que, fixando as famílias nos seus locais tradicionais de moradia, será a efetivação da conquista de um outro patamar em direção à conquista da cidadania para essas famílias.

A Fase IV do Projeto Cingapura, Programa PROVER, atualmente em finalização, compreende a verticalização de 10 favelas, totalizando 6229 unidades contratadas, conforme dados do Relatório Semestral № 9 - 2 Semestre de 2000.

Foi estabelecida pelo BID, como condição para o financiamento, a exigência de contratação e aprovação de pareceres ambientais para todos os empreendimentos, com acompanhamento durante a fase de obras e aprovação do órgão local responsável pelo licenciamento ambiental.

A crescente preocupação com a temática ambiental ao longo da década de 1990 foi um dos fatores determinantes da ação do BID. Ela atende à pressão da opinião pública internacional mas também aos interesses dos financiadores que não desejam ver seus projetos associados à degradação ambiental (FORATO, 2003).

\footnotetext{
${ }^{8}$ Relatório de monitoramento e avaliação de impactos em favelas e loteamentos irregulares do Programa BID 938/0c, 2001, p. 38.
} 


\subsubsection{Os Custos do Projeto Cingapura}

Os custos praticados nas quatro fases de implantação do Projeto Cingapura não estão disponiveis para consulta pública nos arquivos da Prefeitura Municipal de São Paulo. Até o presente momento, também não se dispõe de nenhuma publicação que divulgue tais dados abrangendo a totalidade do programa.

Apesar da falta de informações mais precisas dos custos totais dos empreendimentos que contemple todos os componentes envolvidos: terreno, infra-estrutura, edificações, projeto e planejamento e BDI, existem algumas informações fragmentas sobre tais custos, que embora não possam ser generalizadas para todo o Programa, servem como um referencial.

Tabela 18 - Projeto Cingapura: Custos de Edificações praticados nos Empreendimentos da 2afase

\begin{tabular}{lccccc}
\hline \multicolumn{1}{c}{ Empreendimento } & $\begin{array}{c}\text { Data do } \\
\text { contrato }\end{array}$ & $\begin{array}{c}\mathrm{N}^{\circ} \text { de } \\
\text { prédios }\end{array}$ & $\begin{array}{c}\mathrm{N}^{\circ} \text { de } \\
\text { UH }\end{array}$ & $\begin{array}{c}\text { Valor das } \\
\text { edificações }\end{array}$ & $\begin{array}{c}\text { Valor por UH } \\
\text { (edificações) }\end{array}$ \\
\hline Dom Macário & 1995 & 4 & 96 & $1.645 .894,69$ & $17.144,74$ \\
Santo Antonio - Pq. Otero & 1995 & 25 & 500 & $9.251 .636,98$ & $18.503,27$ \\
Heliópolis - Gleba - L2 & 1995 & 30 & 600 & $15.608 .763,28$ & $26.014,61$ \\
José Paulino dos Santos & 1995 & 9 & 180 & $3.832 .268,79$ & $21.290,38$ \\
Edu Chaves & 1995 & 20 & 400 & $7.810 .711,55$ & $19.526,78$ \\
Chaparral & 1995 & 14 & 280 & $5.665 .956,10$ & $20.235,56$ \\
Chaparral / Tiquatira & 1995 & 10 & 200 & $3.987 .377,27$ & $19.936,89$ \\
Haia do Carrão & 1995 & 12 & 240 & $4.665 .342,98$ & $19.438,93$ \\
Vila Nilo & 1995 & 13 & 260 & $5.025 .577,88$ & $19.329,15$ \\
Raul Seixas & 1995 & 4 & 112 & $2.476 .712,81$ & $22.113,51$ \\
São Francisco - área I & 1995 & 4 & 80 & & $22.684,56$ \\
São Francisco - área II & 1995 & 4 & 80 & & \\
São Francisco - área III & 1995 & 2 & 40 & $23.047 .512,31$ & \\
São Francisco - área IV & 1995 & 9 & 196 & & $21.090,91$ \\
São Francisco - área V & 1995 & 17 & 340 & & $21.097,61$ \\
São Francisco - área VI & 1995 & 14 & 280 & & \\
São Jorge Arpoador & 1995 & 17 & 562 & $11.853 .090,66$ & \\
Uirapuru & 1995 & 11 & 418 & $8.818 .800,67$ & \\
\hline
\end{tabular}

Fonte: Relatórios de Gerenciamento/ PROVER -HABI/BUREAU/DUCTOR 


\section{capítulo 3}

\section{Análise dos Empreendimentos}

Neste capítulo são apresentados os dois empreendimentos escolhidos para a investigação proposta pela pesquisa: o Mutirão Campanha Gaúcha e o Cingapura Imigrantes. Em seguida, é apresentada a metodologia de pesquisa utilizada para abordar os dois empreendimentos e, finalmente, são expostos os resultados da pesquisa divididos em duas etapas:

- a pesquisa qualitativa, realizada através de entrevistas realizadas com os principais atores sociais envolvidos.

- a pesquisa quantitativa, realizada através da aplicação de um questionário de avaliação de qualidade de vida desenvolvido pela Organização Mundial de Saúde- OMS.

A discussão sobre os resultados apresentados será objeto do próximo capítulo.

\subsection{Escolha dos Empreendimentos}

0 critério básico adotado para a escolha dos empreendimentos foi a representatividade dentro da proposta estabelecida pelas diretrizes dos dois programas estudados. Assim, foram escolhidos empreendimentos ditos modelo dentro dos programas, pois estes serviram como referencial para o desenvolvimento de conjuntos posteriores.

No caso do FUNAPS Comunitário, foi escolhido o Mutirão Campanha Gaúcha, situado na Zona Leste de São Paulo, a região mais contemplada pelo programa. O Mutirão Campanha Gaúcha possui 128 unidades habitacionais, número que se situa entre a média estipulada nas diretrizes do programa (mínimo de 20 e máximo de 200 unidades). As casas têm área média de $60 \mathrm{~m}^{2}$, área mínima também estabelecida nas diretrizes do programa.

No entanto, a principal característica do Mutirão Campanha Gaúcha, que o coloca como um exemplo do FUNAPS Comunitário, foi a autonomia da associação de moradores para gerir todos processos envolvidos na produção das casas. Autonomia esta que propiciou ao mutirão continuar as obras mesmo com o corte de verbas da prefeitura em 1993 (mudança de gestão).

No caso do Projeto Cingapura, foi escolhido o empreendimento Imigrantes, que se situa no início da Rodovia dos Imigrantes, Zona Sul de São Paulo. 0 Cingapura Imigrantes é composto por 160 unidades divididas em 8 blocos de 5 pavimentos com 4 apartamentos por andar - tipologia adotada como modelo para Projeto Cingapura em sua primeira fase. 
A opção por este empreendimento deu-se pelo fato do mesmo ter sido um dos primeiros conjuntos inaugurados do programa, em dezembro de 1994, considerado como projeto-piloto do Programa de Verticalização de Favelas - PROVER.

\subsection{Conjunto Habitacional Campanha Gaúcha}

\subsubsection{Localização}

0 Conjunto Habitacional Campanha Gaúcha está localizado próximo à Estação Ferroviária Guaianazes, no bairro Lajeado, zona Leste de São Paulo, distante aproximadamente $20 \mathrm{Km}$ do centro da cidade. Tem como limites físicos a Rua Campanha Gaúcha, Rua Pascoal Diário e a Avenida Nordestina.

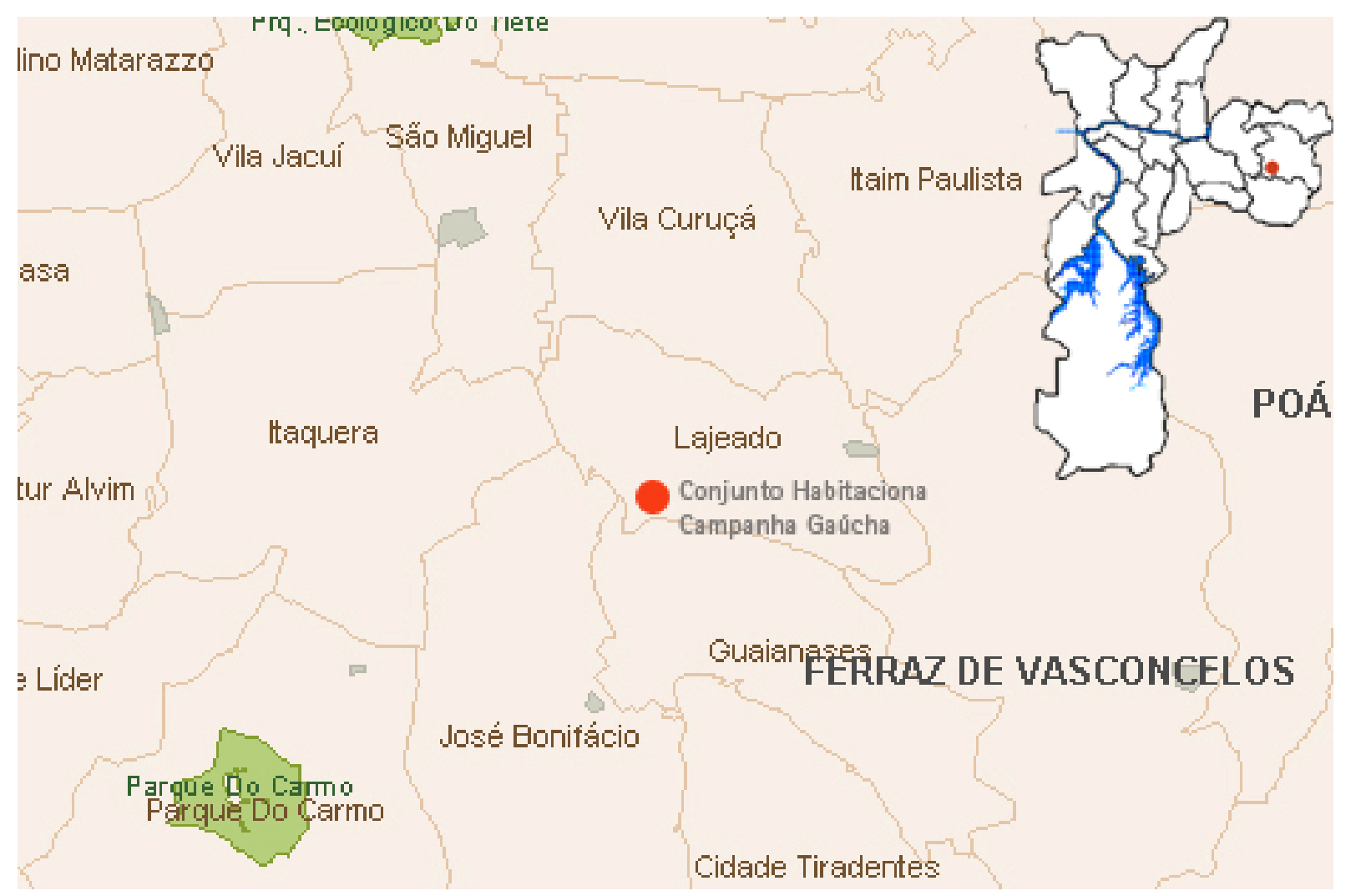

Figura 11 - Localização do Conjunto Habitacional Campanha Gaúcha.

\subsubsection{Histórico e Principais Características do Conjunto}

A associação dos moradores do Conjunto Habitacional Campanha Gaúcha se formou a partir de grupos de bairro da zona Leste, parte Cidade Líder de Itaquera e parte Guaianazes, que se reuniam na igreja do bairro em torno da questão da moradia.

Em janeiro de 1990, firmaram convênio com o FUNAPS Comunitário para a construção de 127 unidades habitacionais em regime de mutirão. Quando da definição do projeto possibilitou-se a implantação de 128 unidades habitacionais e o convênio foi aditado 0 
convênio. 0 empreendimento conta 108 unidades do tipo sobrado geminado e 20 do tipo casa sobreposta, com forme ilustração abaixo.

A implantação das unidades respeitando a topografia original do terreno, ocasionou a adoção das casas sobrepostas nas proximidades da Avenida Nordestina.
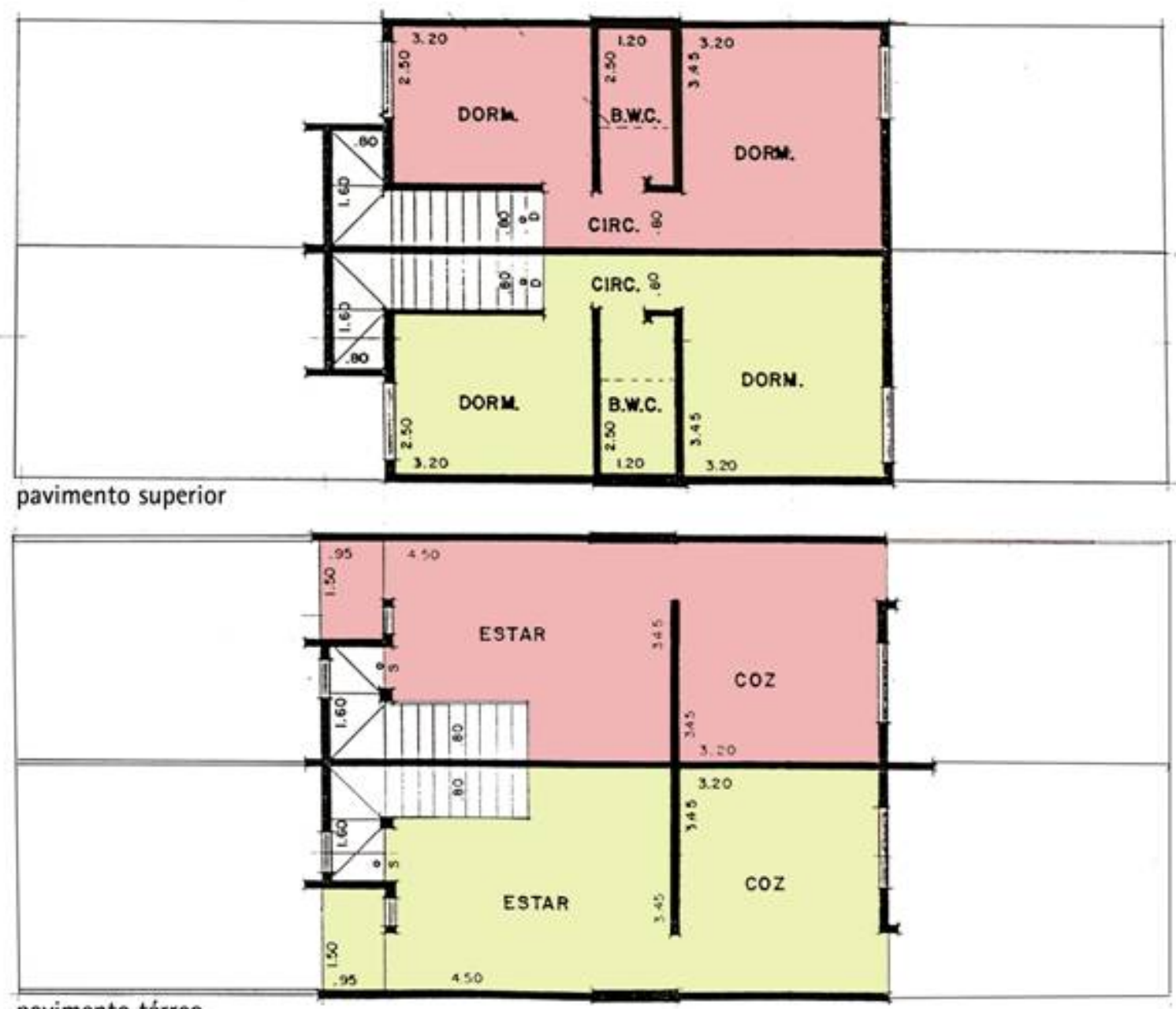

pavimento térreo

Figura 12 - Tipologia 1 Campanha Gaúcha 

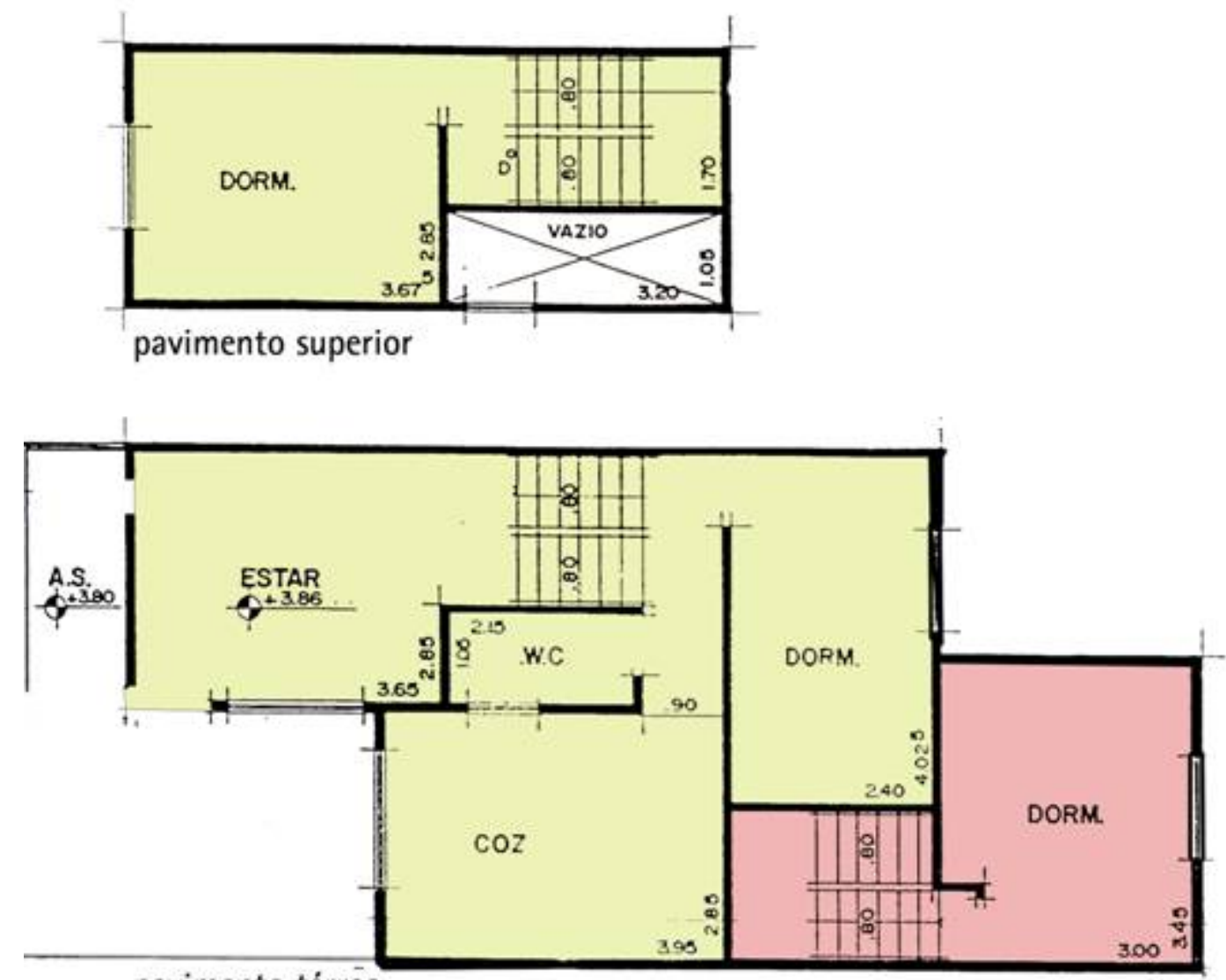

pavimento térreo

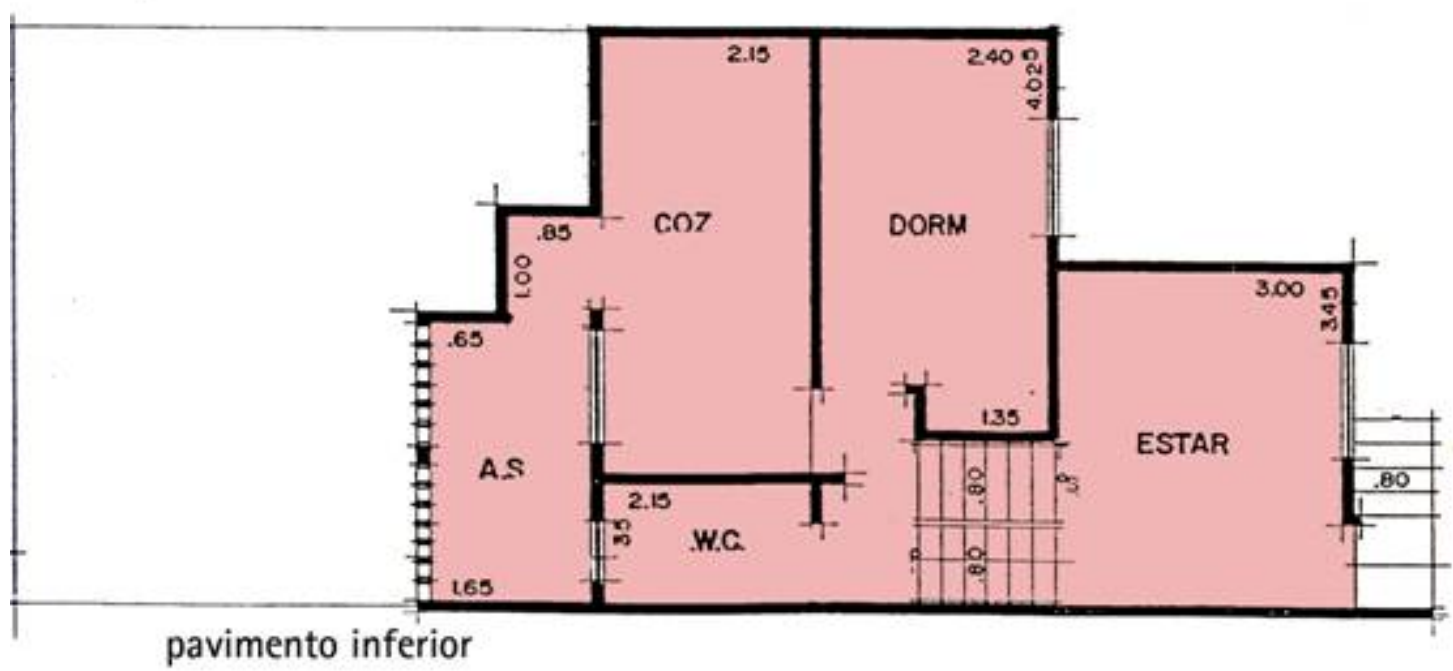

Figura 13 - Tipologia 2 Campanha Gaúcha

Os projetos de infra-estrutura foram feitos pela Pertécnica e a empresa DUCTOR foi responsável pelo gerenciamento das obras de infra-estrutura. A assessoria técnica ficou a cargo da TETO - Assessoria Técnica a Movimentos Populares.

0 sistema viário foi projetado com um único acesso pela Avenida Nordestina, de forma a evitar o tráfego de passagem. 
0 Campanha Gaúcha foi edificado em uma área de 15.230,44m². Consta do Relatório de gestão de $H A B I$ que o terreno foi adquirido em 15 de novembro de 1990, porém, até o momento, os moradores não assinaram nenhum tipo de contrato com a $\mathrm{COHAB}$, órgão atualmente responsável pelo empreendimento, que alega irregularidades jurídicas na área.

0 tipo de contrato proposto por $\mathrm{HABI}$ na ocasião da assinatura do convênio foi contrato mútuo para financiamento de material e outras despesas correlatas à construção de uma unidade habitacional, com carência.

Ao final da gestão Erundina, 70\% das casas estavam concluídas e com 71 unidades habitacionais ocupadas.

\subsubsection{Custos do Campanha Gaúcha}

Os quadros a seguir apresentam o resumo dos custos do empreendimento, baseados nas informações apresentadas no Relatório de Gestão de HABI 1989/1992.

Tabela 19 - Resumo dos custos do Campanha Gaúcha (valores em US\$)

\begin{tabular}{lcc}
\hline & & custos \\
\hline Terreno & & $115.354,59$ \\
Projeto & $12.001,67$ \\
Obra & Infra / Fundação & $118.792,72$ \\
Total & Edificação & $716.735,03$ \\
\hline
\end{tabular}

Fonte: PMSP, 1992.

Tabela 20 - Índices

\begin{tabular}{lccrr}
\hline & unidade & obra & Total \\
\hline & & Infra / Fundação & Edificação & \\
\hline Área urbanizada $\left(15.230,44 m^{2}\right)$ & US\$/m² & 7,80 & 47,06 & 63,22 \\
Unidade habitacional & US\$/UH & 928,07 & $5.599,49$ & $7.522,53$ \\
Área edificada & US\$/m² & 15,47 & 93,32 & 125,38 \\
\hline
\end{tabular}

Fonte: PMSP, 1992.

\subsubsection{Situação atual}

Segundo relato dos moradores, após a interrupção do repasse de verbas, as obras continuaram com recursos dos próprios mutirantes. Cerca de 20 famílias mudaram para as casas ainda inacabadas, evitando assim as despesas com o aluguel e o risco de invasões. Do início da construção até que todas as famílias ocupassem suas casas, foram 5 anos.

Hoje, 16 anos depois, as 128 famílias ainda se reúnem todo primeiro domingo de cada mês para discutir os problemas, planejar as ações, e dividir as tarefas do dia-a-dia, como nos tempos do mutirão. ${ }^{1}$

\footnotetext{
${ }^{1}$ Quando fui recebida pela líder comunitária Izilda em uma segunda-feira à noite, o simples fato de ligar a luz do Centro Comunitário fez com que comparecessem naquele local 8 pessoas.
} 
0 conjunto continua aberto ao bairro, porém, as casas hoje têm muros e grades que não constavam no projeto original, principalmente por causa da garagem, também acrescida.
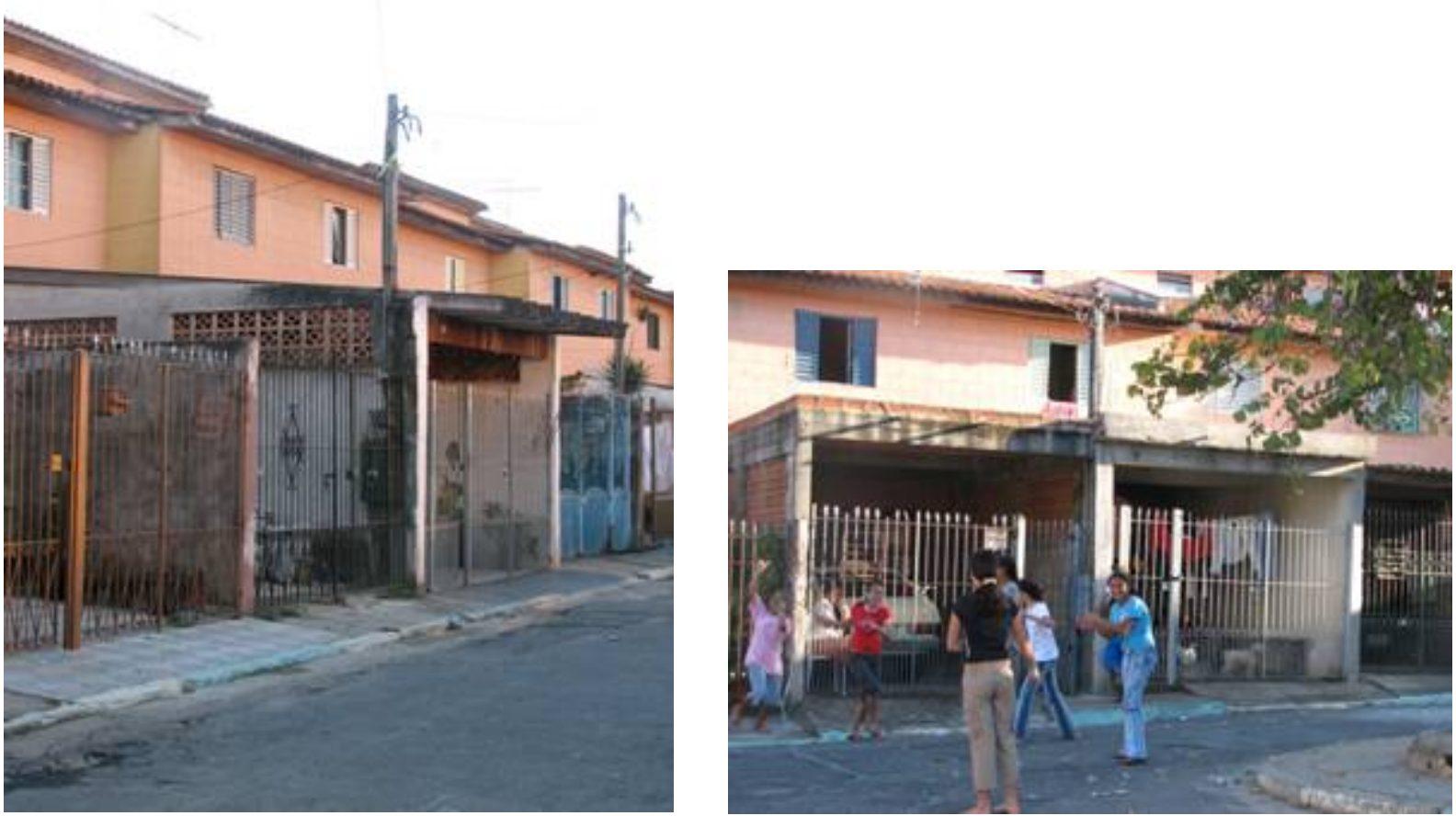

Figuras 14 e 15 - Fotos do Conjunto Campanha Gaúcha (2006)

A divisão interna das casas, não sofreu alterações significativas.
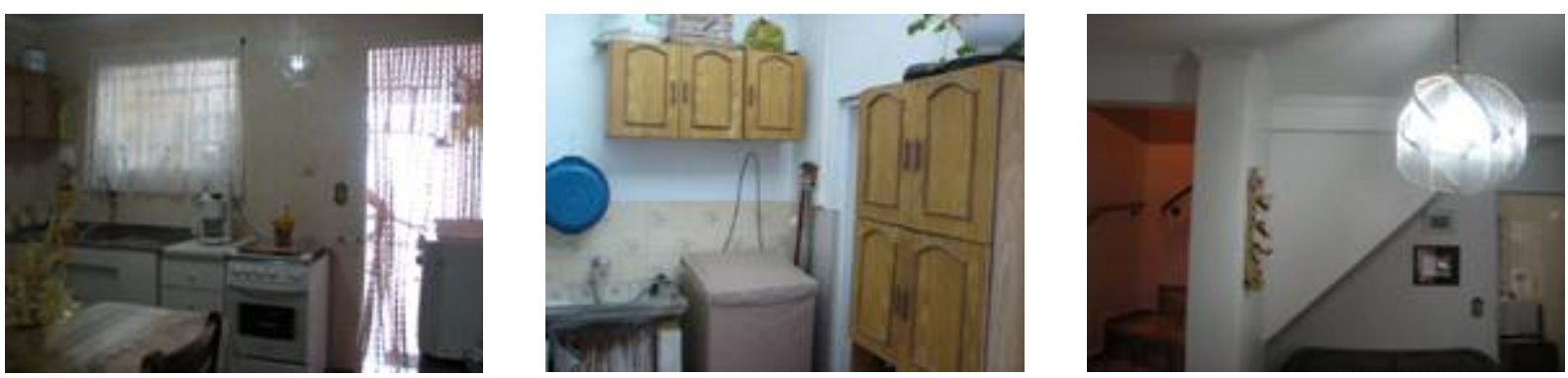

Figuras 16, 17 e 18 - Fotos internas de casas do Conjunto Campanha Gaúcha (2006)

Quase na totalidade das casas, os recuos, tanto de frente, como o de fundo, foram ocupados. 0 recuo de frente, com a garagem e o de fundo com o acréscimo de um banheiro, churrasqueira e, até mais um quarto. 

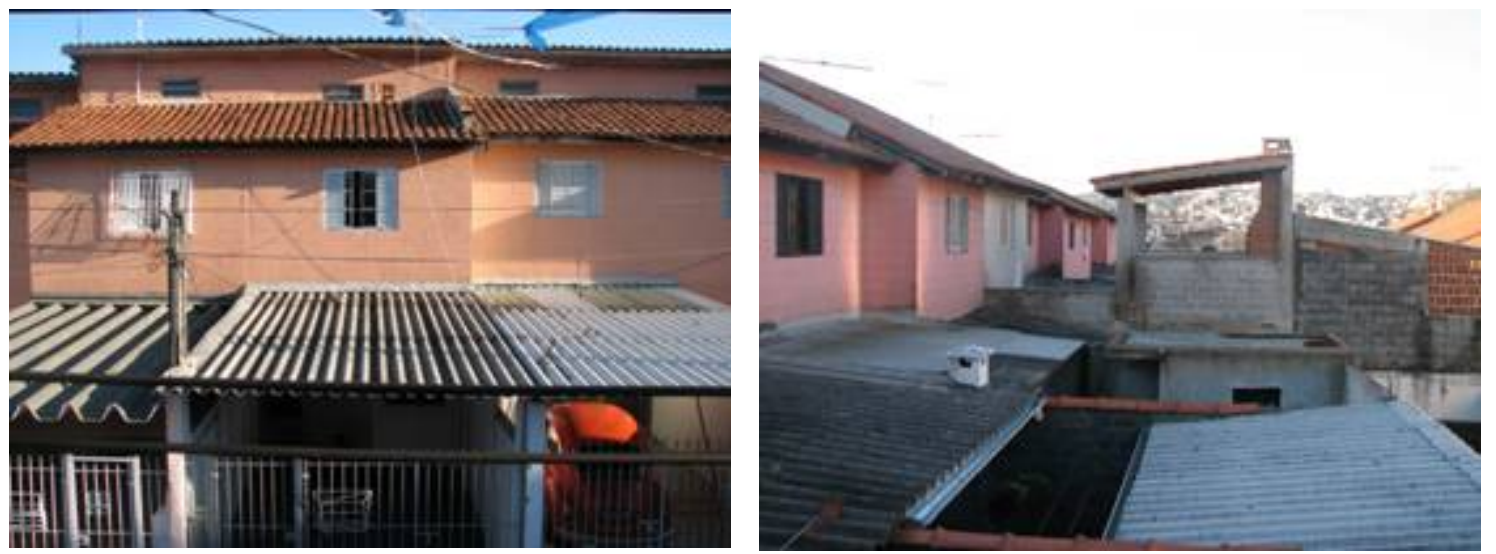

Figuras 19 e 20 - Ocupação dos Recuos no Conjunto Campanha Gaúcha

0 centro comunitário do conjunto, além de servir de local de reunião, também abriga o Programa Leve-Leite atendendo 120 famílias, 20 do Campanha Gaúcha e outras 100 famílias do bairro. Este foi equipado, através de recursos dos moradores, com mesas cadeiras, materiais de apoio às reuniões e um banheiro.

0 campo de futebol situado ao lado do Centro Comunitário, é local de lazer não só para os moradores do conjunto, como para toda a vizinhança. As ruas também são intensamente utilizadas como local de lazer, principalmente pelas crianças.

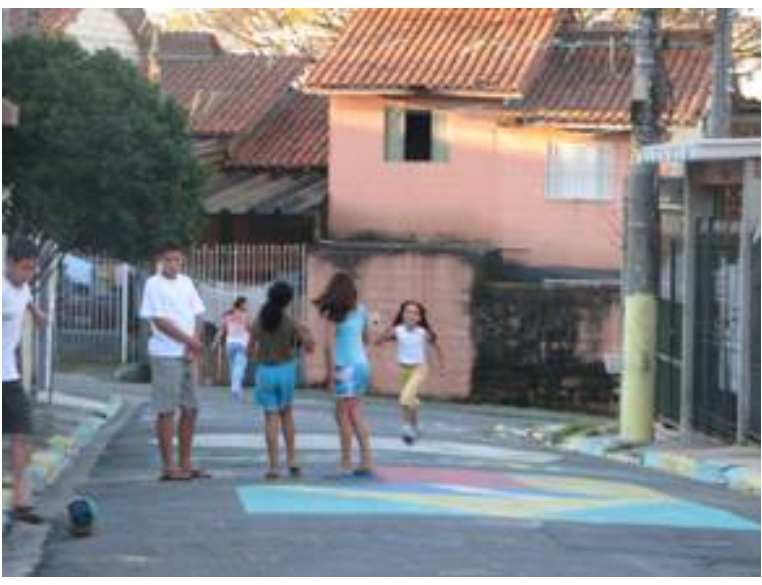

Figura 21 - Rua no Campanha Gaúcha

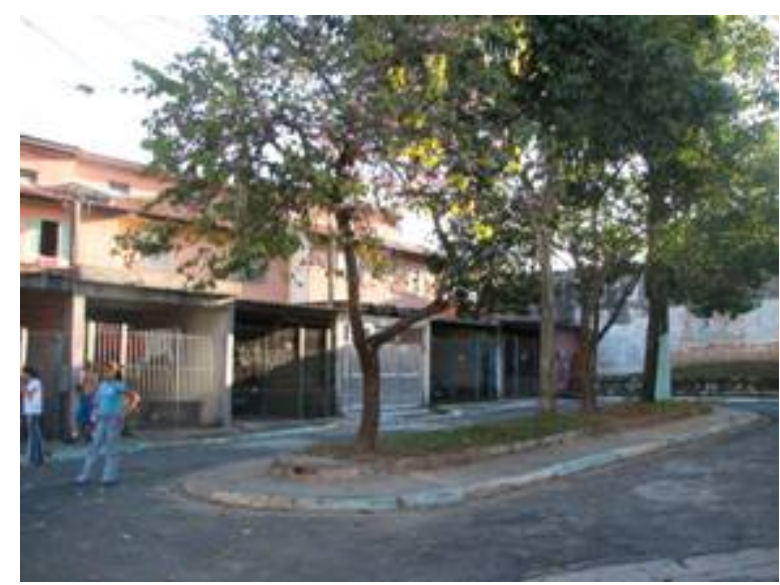

Figura 22- Área Verde no Campanha Gaúcha

As áreas verdes do conjunto ainda continuam destinadas a esse fim. Segundo informações de uma moradora, a limpeza dessas áreas é feita duas vezes por semana em um esquema de revezamento entre os moradores, definido nas reuniões mensais.

A varreção das ruas também é realizada pelos próprios moradores, segundo eles, a prefeitura alega que a área é particular e, portanto, não tem direito a nenhum tipo de manutenção por parte da PMSP, contrariando o cadastro da própria prefeitura onde consta que as ruas do conjunto são de domínio público. 

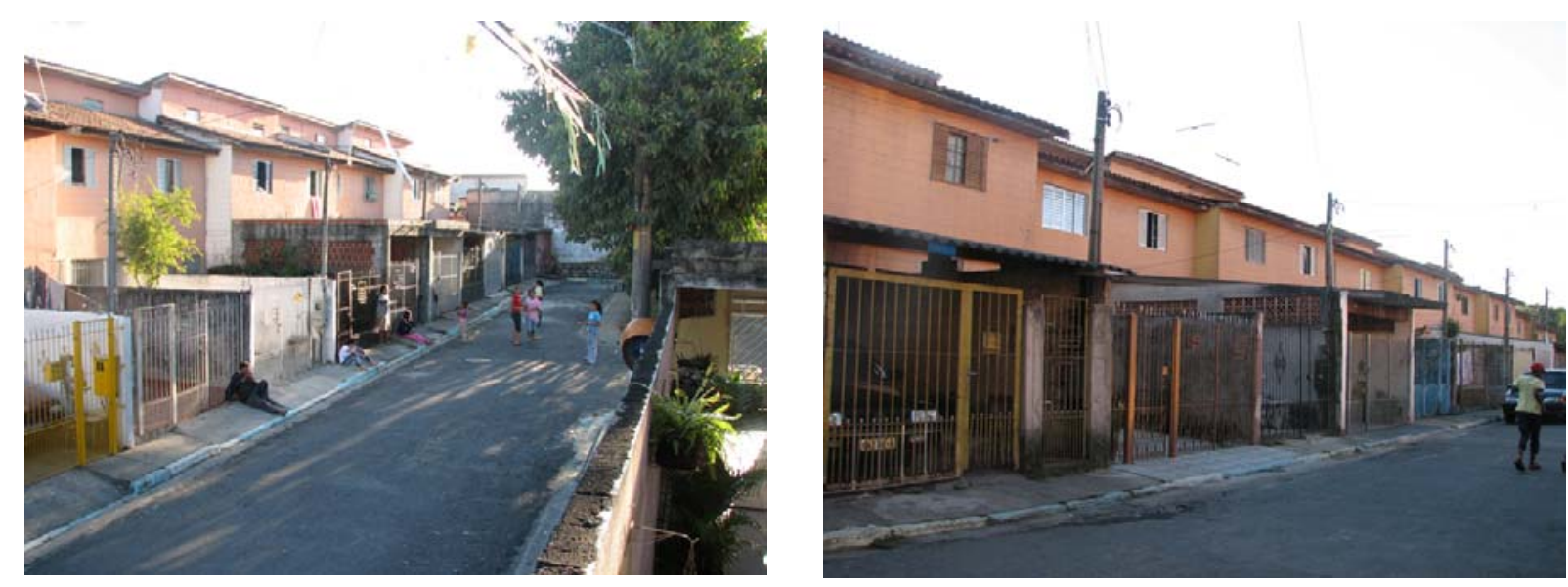

Figuras 23 e 24 - Vista geral de ruas do Campanha Gaúcha

Muitas árvores e plantas ornamentais foram plantadas por moradores dentro do seu lote.
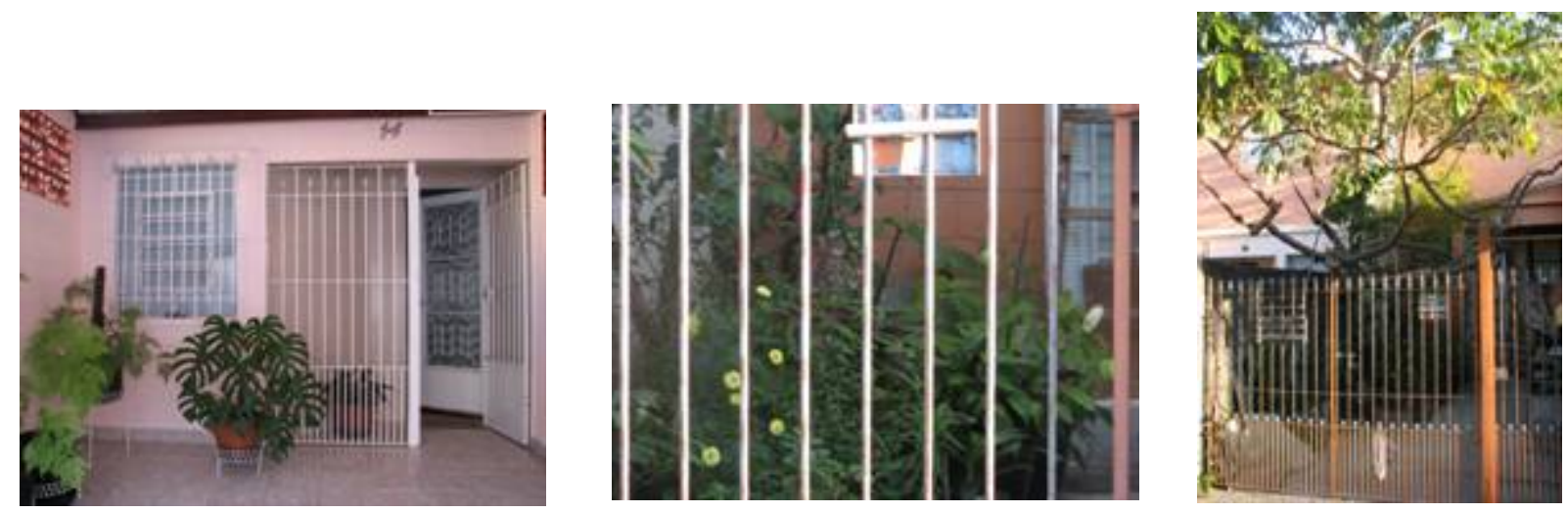

Figuras 25, 26 e 27 - Vegetação dentro de lotes do Campanha Gaúcha

Apesar de terem se passado mais de 15 anos de ocupação, o conjunto ainda não passou por nenhuma reforma. Ele é bem integrado tanto à topografia quanto às tipologias do entorno.

0 Campanha Gaúcha apresenta formações familiares praticamente inalteradas em relação à época de sua inauguração. Segundo os moradores, até hoje foram repassadas aproximadamente 20 casas, geralmente por morte ou mudança do morador original. Esse repasse é feito através de um contrato de gaveta, já que os moradores ainda não possuem nenhum vínculo de propriedade com a casa. 0 contrato de permissão de uso, atual proposição da COHAB, não é aceito pelos moradores.

Não existe nenhum tipo de invasão e nem sinais de vandalismo como vidros quebrados, pixações, etc. 


\subsection{Cingapura Imigrantes}

\subsubsection{Localização}

0 Conjunto Residencial Imigrantes está localizado à Rua Professor Mangue, $n^{\text {os }}$ 5, 20 e 21, próximo ao trevo de acesso à rodovia dos Imigrantes, distante aproximadamente 7,5 $\mathrm{Km}$ do centro de São Paulo. Ao lado desde conjunto, foi edificado outro empreendimento do Projeto Cingapura, também da fase I do Programa, denominado Conjunto Residencial Miguel Stéfano.

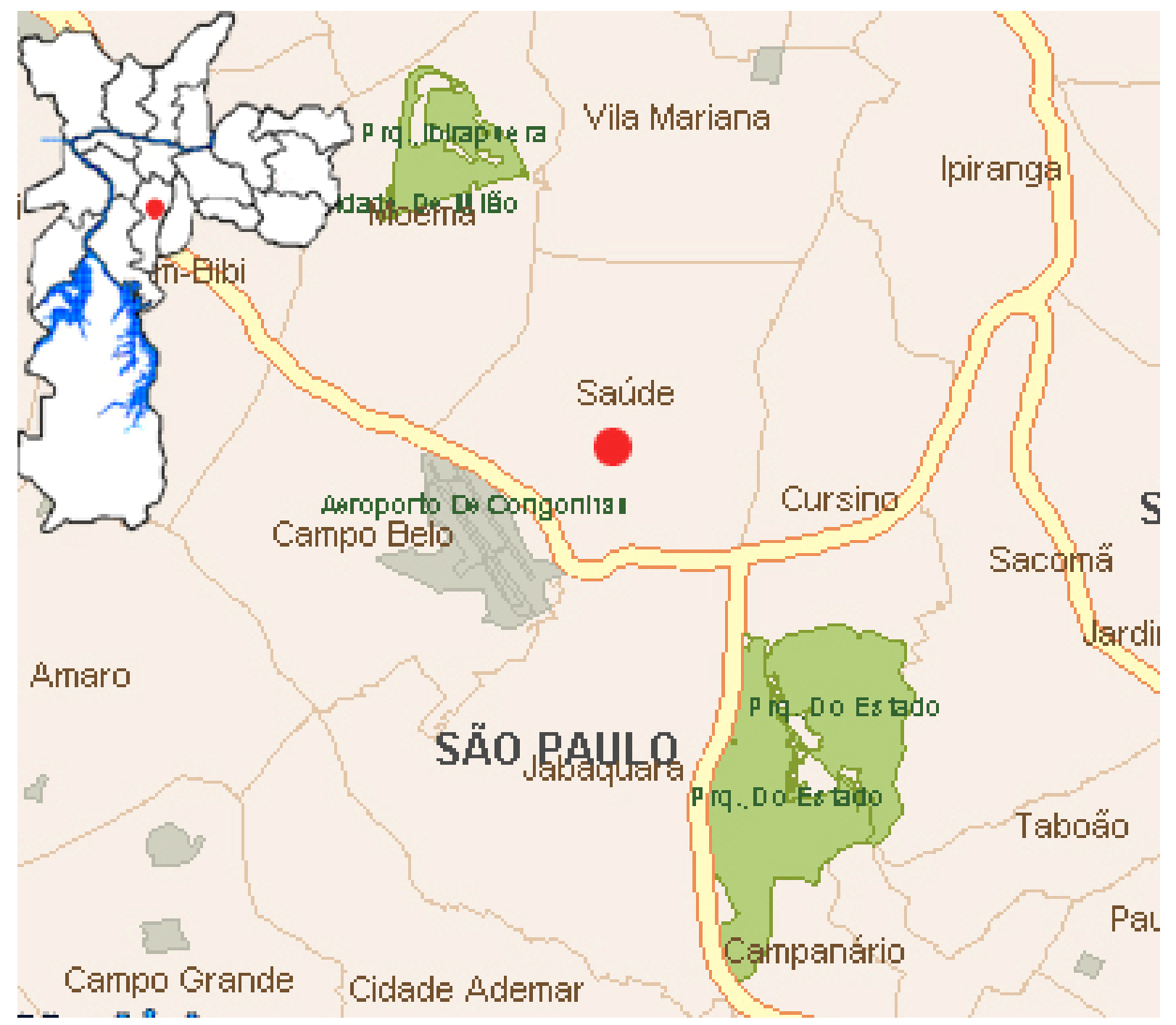

Figura 28 - Localização do Conjunto Habitacional Imigrantes

\subsubsection{Histórico e principais características do Conjunto}

0 Conjunto Cingapura Imigrantes fez parte da fase 1 da implantação do PROVER, e foi inaugurado em 1994. ${ }^{2}$ A construtora responsável pelo empreendimento foi a SCHAHIN, e o gerenciamento ficou a cargo da DUCTOR.

\footnotetext{
${ }^{2}$ Não consta nos arquivos de HABI nenhuma documentação referente a este empreendimento, os dados aqui expostos, são baseados em sua maioria nos depoimentos dos moradores e em uma pesquisa realizada nos arquivos do Jornal Folha de São Paulo.
} 
Antes da construção do conjunto, o local sediava a favela Água Funda, que contava aproximadamente 250 barracos.

0 projeto original previa a construção de 220 apartamentos, porém foram construídas apenas 160 unidades. A tipologia utilizada foi a padrão para apartamentos de 2 dormitórios, dispostos em blocos de 5 pavimentos com 4 apartamentos por andar.
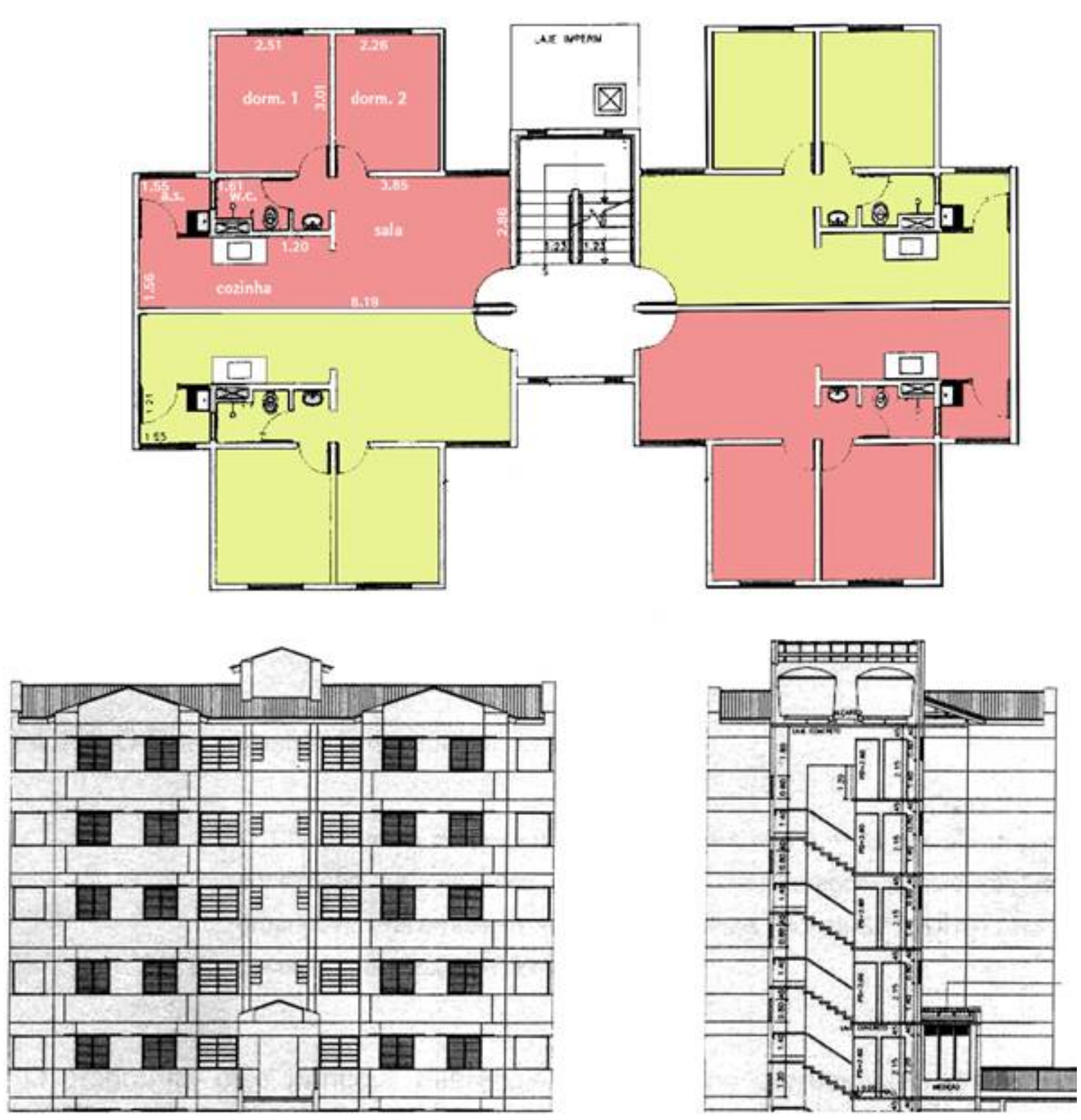

Figura 29 - Tipologia Cingapura Imigrantes

0 local que abrigaria os outros 3 prédios, que completariam o projeto, foi invadido e novamente ocupado por barracos.

Em agosto de 2002, segundo laudos produzidos pelos engenheiros da Divisão Técnica de Projetos e Obras da Coordenadoria de Verticalização de Favela, alguns Cingapura, como o 
Imigrantes, apresentavam deterioração das instalações elétricas e hidráulicas, ocasionando riscos à segurança e à saúde dos moradores. No mês seguinte, um incêndio destruiu entre $35 \mathrm{e}$ 40 barracos que ocupavam a área remanescente da implantação dos prédios. Cerca de 120 pessoas ficaram desabrigadas.

Esse fato impulsionou as obras de reformas do conjunto que custaram em torno de $\mathrm{R} \$$ $534.000,00$. Como o Conjunto ainda era irregular e, portanto, não havia sido repassada a propriedade para os moradores, a prefeitura teve de arcar com os gastos.

\subsubsection{Custos do Cingapura Imigrantes.}

Os quadros a seguir apresentam o resumo dos custos do empreendimento.

Tabela 21 - Resumo dos Custos do Cingapura Imigrantes (em US\$)

\begin{tabular}{lcc}
\hline & & custos \\
\hline Terreno & & (área pública) \\
Projeto & $?$ \\
Obra & Infra / Fundação & $3.590,02$ \\
& edificação & $10.890,27$ \\
Total / UH & & $14.480,29$ (fora terreno) \\
Total da Obra & & $2.331 .417,02$ (fora terreno) \\
\hline
\end{tabular}

Fonte: FORATO, 2004 e PEREIRA, 2001.

Não foram disponibilizados dados mais precisos referentes aos custos desse empreendimento, nem por parte da PMSP, nem através da gerenciadora DUCTOR, que alegou ter entregado todos os documentos concernentes a esse empreendimento para a prefeitura. 0 valor médio do metro quadrado de construção ficou em $R \$ 573,45$, excetuados desse valor o preço do terreno.

\subsubsection{Situação atual}

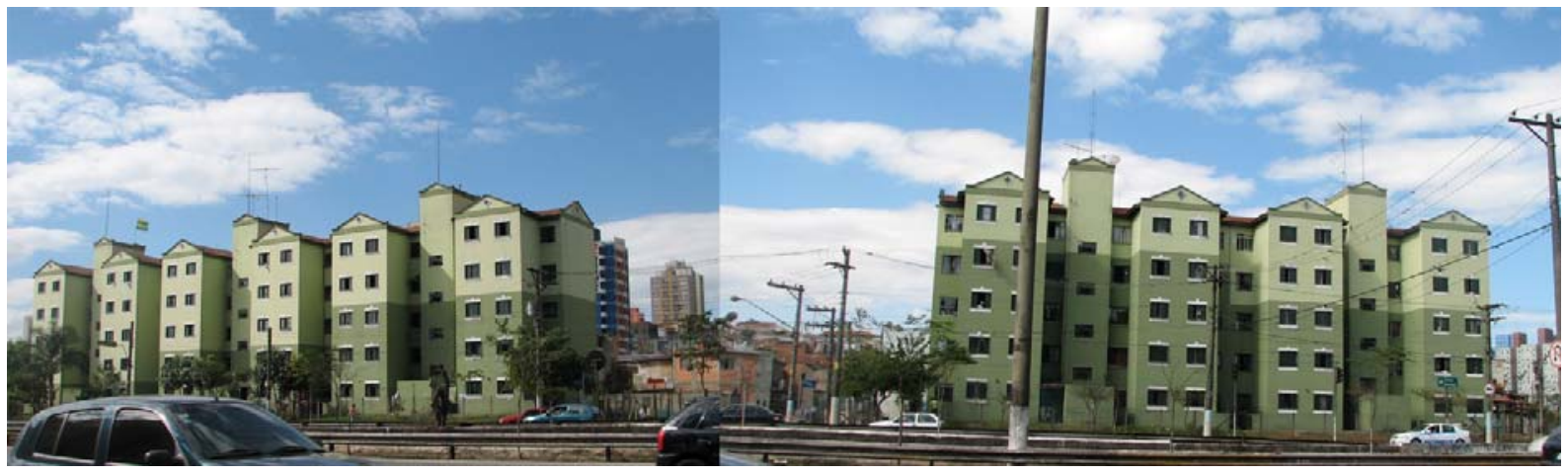

Figura 30 - Visão Geral do Conjunto Cingapura Imigrantes

Dois anos depois do incêndio e de realizada a reforma no conjunto que removeu os barracos de dentro da área e instalou um centro comunitário e dois parquinhos, a situação do conjunto é crítica. 

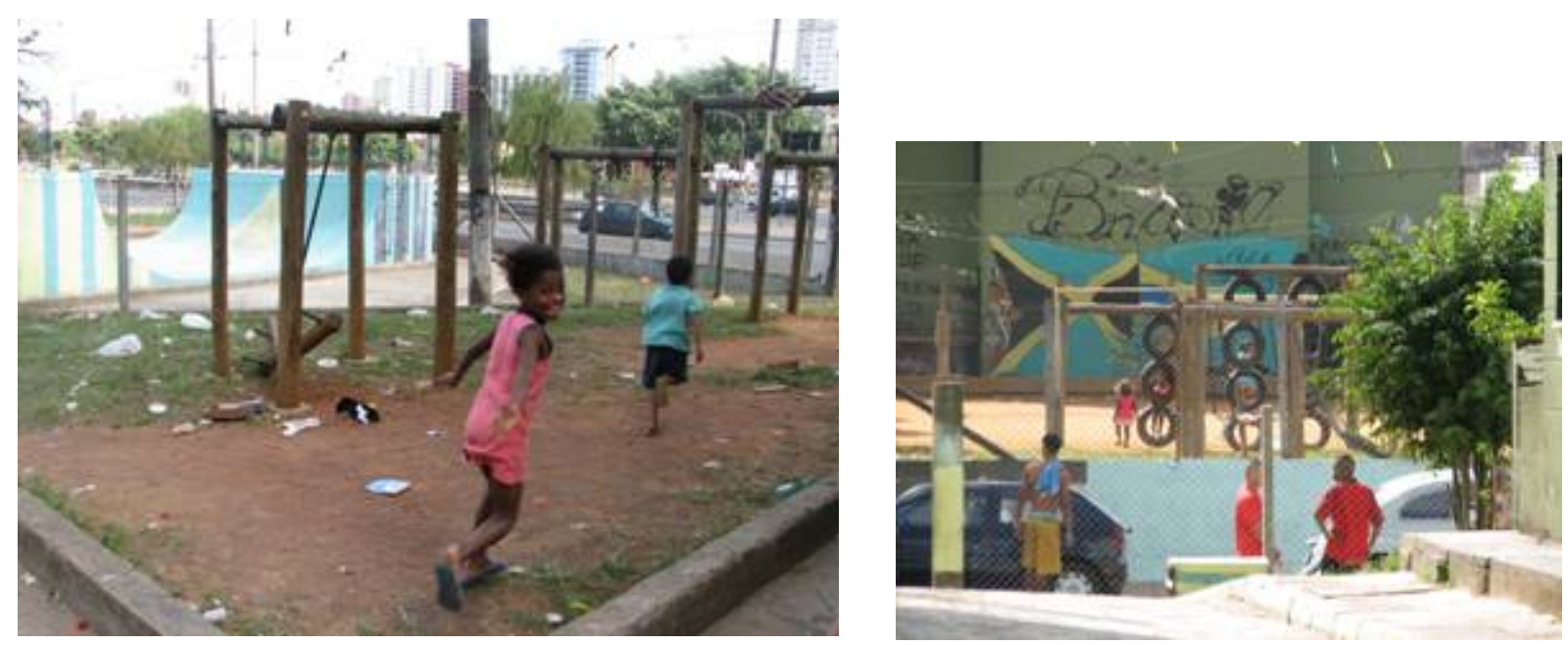

Figuras 31 e 32 - Áreas de Lazer no Cingapura Imigrantes (2006)

As áreas livres são intensamente usadas principalmente pelas crianças. 0 lixo acumulado e a falta de manutenção nesses lugares dão um aspecto de completo abandono.

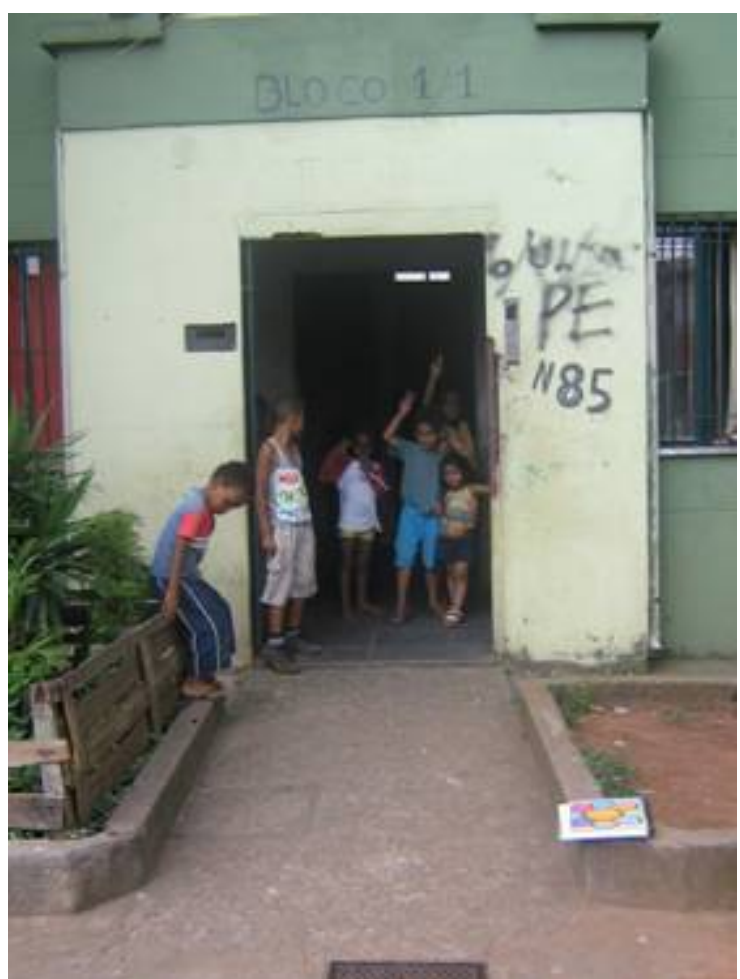

Figura 33 - Entrada de bloco no Imigrantes

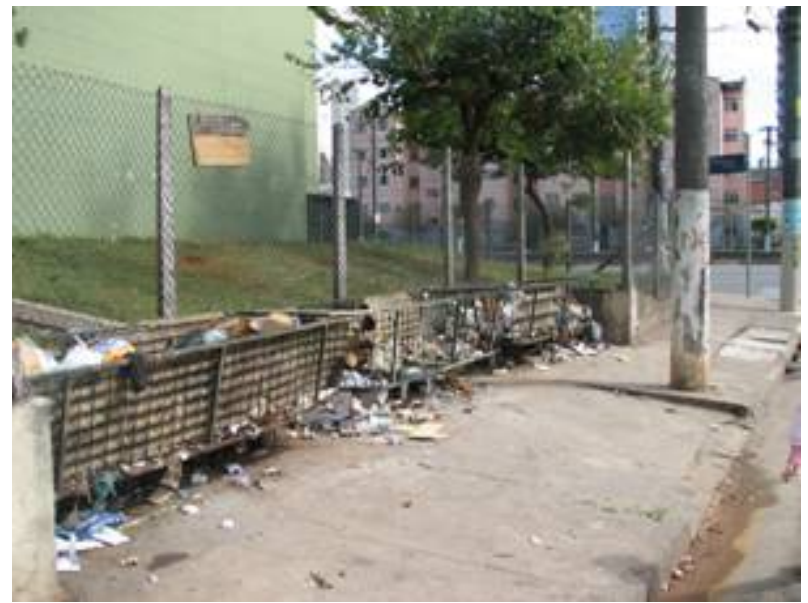

Figura 34 - Lixeiras no Imigrantes

0 centro comunitário é utilizado para as reuniões dos moradores, que não tem periodicidade definida. Este também está tomado por lixo e sem manutenção. Não existe no local nenhum equipamento ou móvel que sirva de apoio para população. 

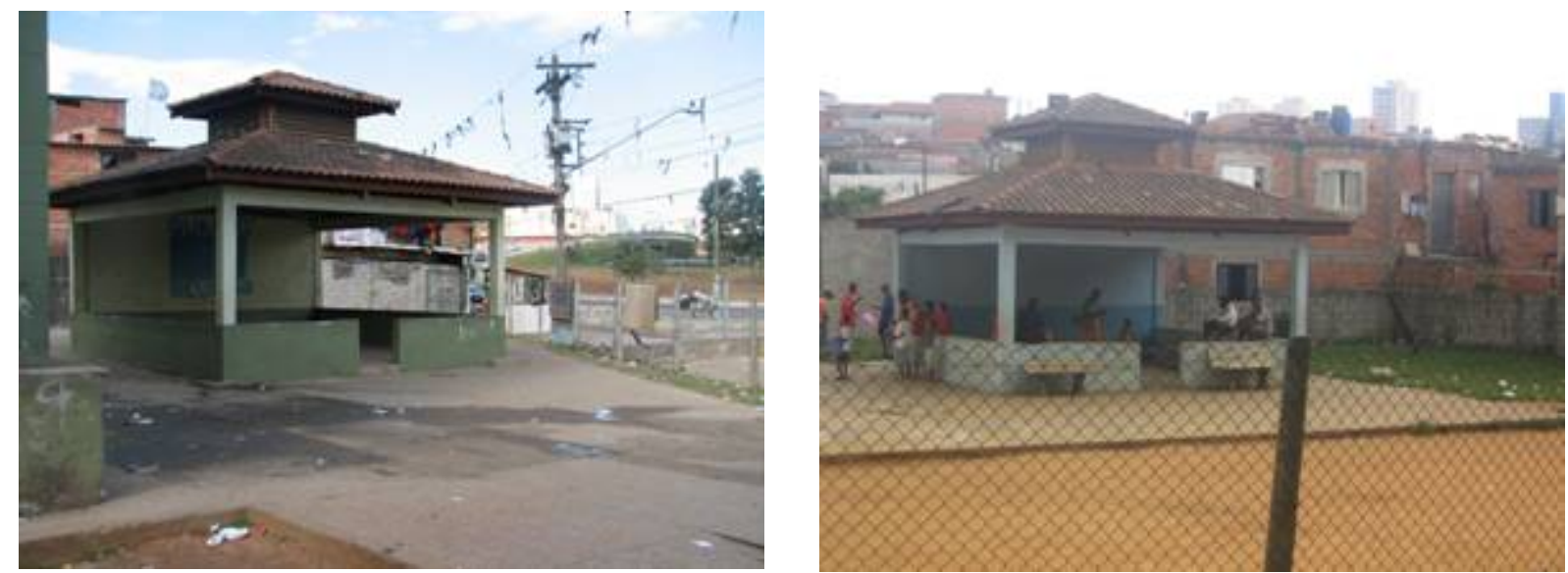

Figuras 35 e 36 - Centro Comunitário do Cingapura Imigrantes

A pintura externa dos prédios está bastante deteriorada pelas pichações e pelos abundantes "gatos" (ligações clandestinas de água e luz).
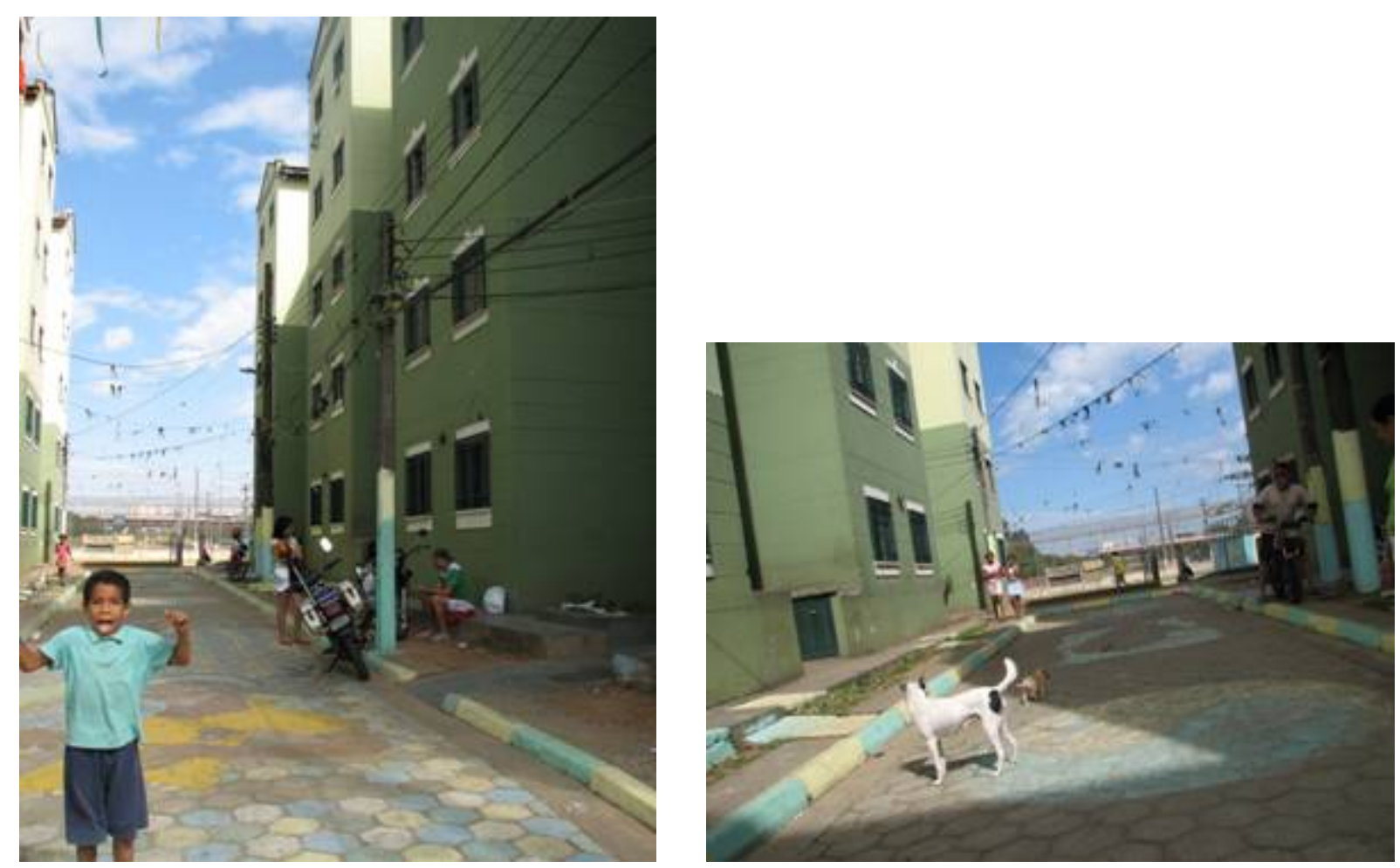

Figura 37 e 38 - Ruas internas do Cingapura Imigrantes

Muitos apartamentos optaram por esse tipo de ligação, ao invés da condominial, tanto de água quanto de energia elétrica.

Internamente, os apartamentos não sofreram alterações significativas. Existem apartamentos extremamente bem cuidados, e outros muito deteriorados. 

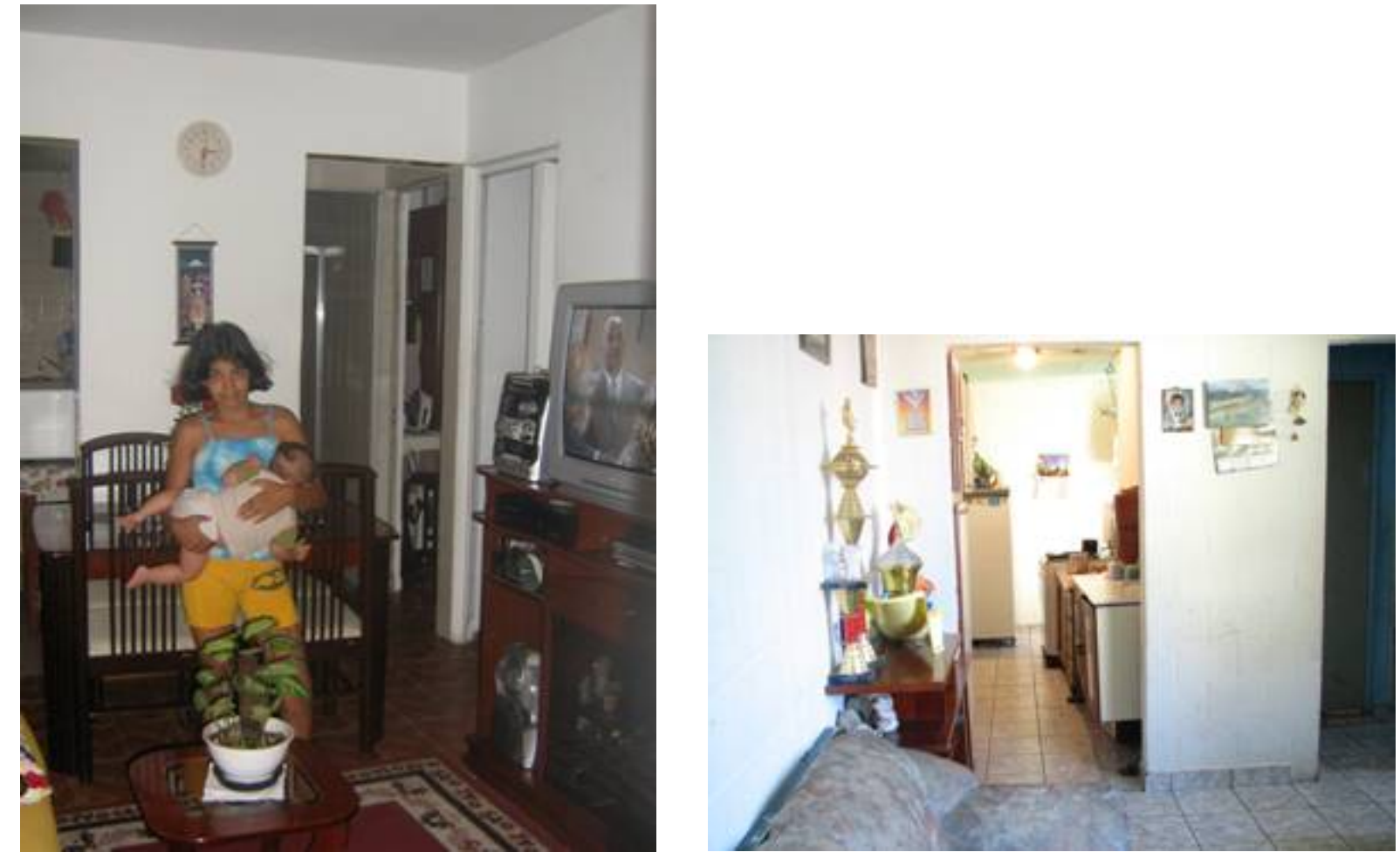

Figuras 39 e 40 - Fotos internas apartamento Cingpaura

0 problema do esgoto é grave no conjunto, o sistema não atende ao fluxo, fazendo com que o esgoto corra a céu aberto, inclusive nos parquinhos. As lixeiras estão deterioradas, sem nenhum tipo de manutenção, nem por parte da prefeitura, nem pelos moradores. 0 sistema de abastecimento de água dos prédios, é feito pela SABESP, e a medição é realizada através de um único hidrômetro por prédio. As contas atrasadas desse condomínio com a SABESP somam em torno de $\mathrm{R} \$ 330.000,00$.

Do lado direito do Conjunto, sentido de que vem pela Rodovia dos Imigrantes, está localizada a Favela da Água Funda, que hoje conta mais de 300 barracos, segundo relato dos moradores. Esta favela é tomada pelo tráfico de drogas, que também comanda o Conjunto.
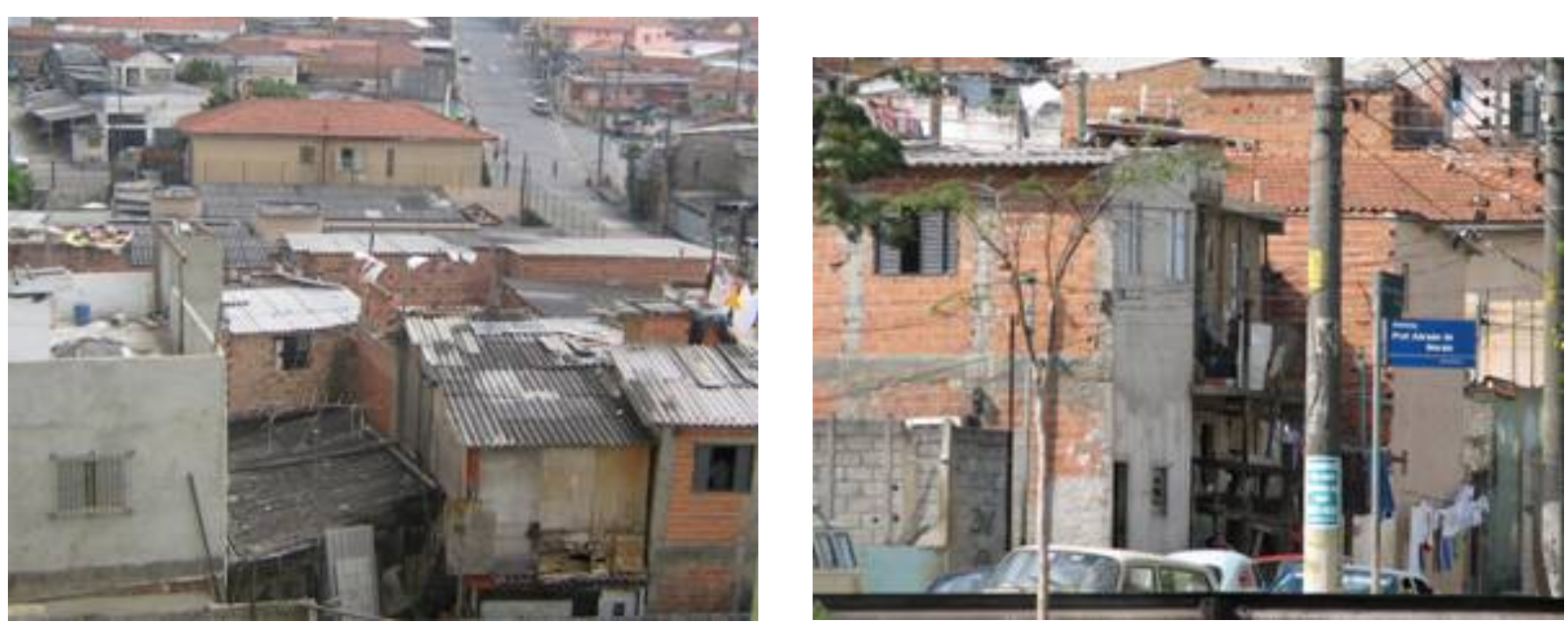

Figuras 41 e 42 - Favela da Água Funda 


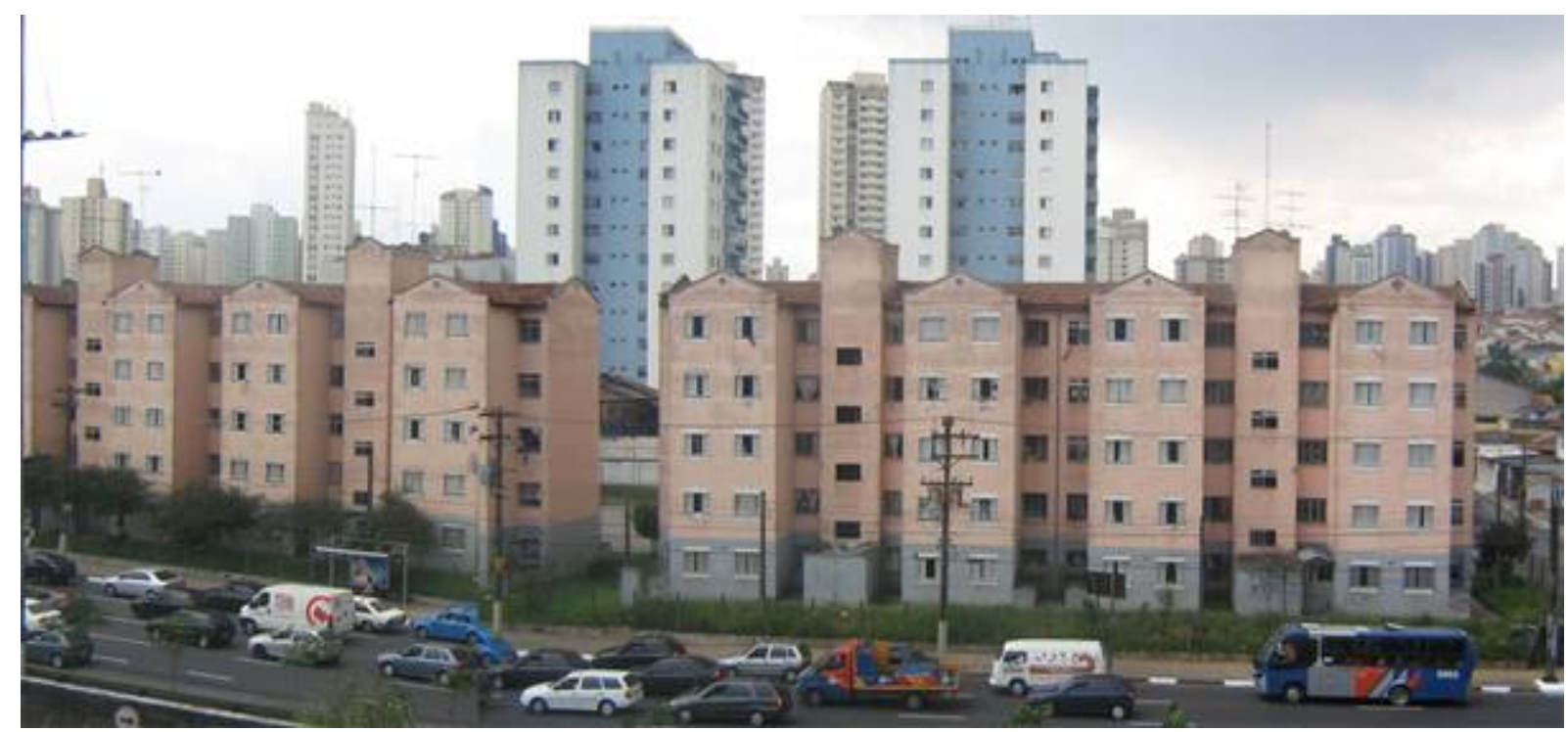

Figura 43 - Visão Geral do Conjunto Cingapura Miguel Stéfano

Do lado esquerdo do Conjunto, também no sentido de quem vem da Rodovia dos Imigrantes, está localizado o Cingapura Miguel Stéfano. Segundo os moradores é mantida boas relações entre os dois conjuntos. 0 Cingapura Miguel Stéfano foi construído no mesmo período do Cingapura Imigrantes e, apesar de não ter passado por nenhuma reforma, apresenta condições de salubridade parecidas com seu vizinho Imigrantes.

Não há uma associação de moradores registrada, porém existe uma liderança identificada no Conjunto, que procura mobilizar os moradores. Esta enfrenta grande resistência à participação dos moradores, e, inclusive, ameaças por parte do crime organizado.

\subsection{A metodologia de pesquisa}

Segundo Antunes (2002), a escolha do método é decorrente do enfoque que se quer dar a análise dos dados obtidos, que constitui essencialmente o pressuposto teórico adotado pelo pesquisador. Nesse sentido, a metodologia buscada para essa pesquisa foi aquela que permitisse trabalhar o problema dentro do seu próprio contexto, aproximando-se de uma visão sistêmica do objeto estudado, o que pode ser considerado uma composição dos métodos qualitativos e quantitativos.

\subsubsection{Método Qualitativo}

Através de uma análise qualitativa baseada em entrevistas realizadas com os principais atores sociais envolvidos, procurou-se não analisar isoladamente a casa, mas mediante a relação que o morador tem com esta, aproximando-se de um método utilizado nas investigações sociológicas balizado nas "práticas do cotidiano".

Segundo Maria Irene Szmrecsanyi (1985), a riqueza extrema do cotidiano é abrigar a percepção da realidade no próprio ato de sua realização. A análise tem, necessariamente, de se 
manter rente ao concreto, isso obriga a se penetrar na complexa variedade da criatividade humana, levando ao desvendamento das soluções-padrão e das fugas aos modelos.

Para Bakhtin (1992), não é possivel compreender o homem, sua vida, seu trabalho,suas lutas, senão por meio de textos signos criados ou por criar. Nesse sentido, o homem não pode ser estudado como um fenômeno da natureza, como coisa. A ação física do homem precisa ser compreendida como um ato, porém, este ato não pode ser compreendido fora de sua expressão "sígnica", que é por nós recriada.

Quando se estudam as relações humanas, como esta pesquisa pretende, são buscados e encontramos signos através das investigações, sendo necessário compreender seu significado. Nas ciências humanas, portanto, se trabalha com a interpretação das estruturas simbólicas. É por isso, segundo Freitas (2002), que não se pode pretender, chegar à cientificidade própria das ciências exatas. Há que se reconhecer que a simbologia não é uma forma não científica do conhecimento, senão uma forma outra do conhecimento que tem suas leis internas e seus critérios de exatidão.

$\mathrm{Na}$ tentativa de estabelecer um diálogo e uma interação com os moradores dos conjuntos escolhidos como estudo de caso, de maneira que a investigação fosse construída dentro do fenômeno estudado, foi utilizada a técnica de entrevistas semi-diretivas onde se mesclavam itens de investigação livre e questões formuladas de forma pré-fixada, através do seguinte roteiro experimental:

Roteiro 1

1 - Como você avalia o lugar aonde você mora hoje?

3 - Como você imagina que seria uma casa ideal No que diz respeito à qualidade do transporte, à disponibilidade de serviços públicos, como escolas, creches, postos de saúde, lazer, etc.

para você morar hoje, dentro das suas necessidades e condições?

2 - 0 que você acha da casa onde você mora atualmente?

4 - 0 que você espera do lugar e da casa onde você está pretendendo morar?

Com base neste roteiro, foram realizadas no dia 16 de outubro de 2005, entrevistas com 11 famílias que submetiam-se a uma seleção realizada pela Caixa Econômica Federal, para ter acesso ao Programa de Arrendamento Residencial - PAR. Os resultados dessas entrevistas, embora interessantes, foram questionáveis. As respostas, na maioria das vezes, foram limitadas a literalmente à pergunta, sem abrangência dos aspectos sociais relacionados à vida do entrevistado, de interesse fundamental para a pesquisa. A entrevista transcrita abaixo exemplifica tal fato. 


\section{Entrevista 1 (roteiro teste)}

Elisângela, Flávio e Fernanda. (Casal jovem e filha, moram em uma casa alugada)

\section{Como é o lugar aonde vocês moram?}

Tem espaço bastante,é uma casa boa. Não tem quintal, é em cima de um comércio pra carros, assim,o bairro não é muito bom.

\section{E o transporte, como é?}

É perto do metrô Guilhermina, Patriarca. Mas, assim, agente tem carro também.

É casa própria?

Não, é alugada.

\section{Quanto vocês pagam?}

$\mathrm{R} \$ 300,00$

Disponibilidade de creche, posto de saúde, tem perto?

Têm, hospital bem perto, posto três quadras pra frente.

Como vocês imaginam uma casa ideal pra vocês morarem, dentro das suas necessidades e daquilo que vocês podem pagar?

Pode ser uma casa ou um apartamento, dois quartos, sala, cozinha, banheiro, lavanderia, entendeu? Não precisa ser muito grande nem muito pequena também, mas que a gente tenha um lugar confortável e agradável, e uma garagem pra gente por o carro porque a gente aluga.

Que nem, se sair esse apartamento eu vou ter que levantar um coberto, porque só marca no chão né, e eu não confio em deixar meu carro. Porque, assim, a gente paga né, demorou três anos pagando este. É duro você deixar nem é por causa de roubo mas alguém risca...

Vocês sabem aonde é o conjunto que vocês estão pleiteando?

Então, nós temos mais ou menos uma idéia, inclusive nós vamos passar lá depois que sair daqui, meu irmão mora no conjunto José Bonifácio e a Tia dele também.

Alguma coisa que vocês queiram falar? De conjunto habitacional, alguma expectativa?

Se você me falasse um ano atrás eu jamais ia morar, entendeu? Quando você fala de projeto do CDHU, ou conjunto habitacional, o pessoal já imagina morar em uma favela em pé, só que hoje tem vários conjuntos do CDHU, por exemplo, que são mais bonitos que prédios particulares. Na realidade, a Caixa, o Governo, dão lugar pra você morar, agora, o que você vai fazer dele depende da pessoa que você coloca pra morar. Nós sabemos as condições que nos temos pra morar, as vezes a cabeça de quem mora é mais importante do que tudo. Você coloca uma pessoa lá que tem condições de pagar os 300 reais mas a cabeça dela é de 50, então, ela vai tornar uma favela nem que seja um apartamento de 1000 reais, depende da pessoa. Às vezes o povo exige muito mas na hora que tem uma oportunidade, transforma o que o governo dá em coisa destrutiva pra ela mesmo, você vê por aí roupas penduradas, uns negócios pendurados. Parece uma favela em pé, não é por que foi feito daquela forma,as pessoas que deixaram daquele jeito, porque mesmo que você tem espaço, não precisa ser enorme, confortável pra você, o que você vai fazer dele depende do que você é. Você vai por dentro da sua casa o que você é por dentro. Só que assim, tem que ser muito analisado mesmo, voga muito a pessoa que você vai colocar lá, não adianta você fazer um prédio bom, e colocar lá gente que vai destruir tudo o que o governo construiu, paga um arquiteto, uma empresa, porque, mesmo que o governo constrói, sai do nosso bolso. Nós moramos juntos há nove anos e pagamos aluguel há seis já, se estivesse pagando nossa casa seis anos já estavam pagos. Se já a gente não for aprovado, a gente não vai querer mais porque que a gente vai pegar uma coisa que já foi usado?

Uma possivel causa da inibição observada nessas entrevistas pode ter sido o fato dessas pessoas terem sido entrevistadas fora do seu local de moradia. A entrevista foi realizada no escritório da administradora do conjunto, fato que pode ter ocasionado também a "obrigação" em se submeter à entrevista.

Procurando corrigir as falhas detectadas na aplicação do roteiro teste, e direcionar as entrevistas para as questões que a presente pesquisa procura discutir, foi elaborado um novo roteiro, apresentado a seguir. 


\section{Roteiro para entrevista}

\section{Trajetória Habitacional}

- Como era a situação das moradias das pessoas antes de virem para cá?

- Você acha que aqui é melhor ou pior do que o lugar onde as pessoas moravam antes?

- Como foi o processo até vocês chegarem aqui?

\section{Caracterização da Moradia}

- Quem fez esse conjunto?

- A casa é sua? Você paga alguma coisa por mês?

- Como são as condições de infra-estrutura

- Localização em relação o trabalho

- As pessoas têm parentes, vínculos familiares nesse conjunto

- 0 senhor gosta dessa casa?

- As pessoas gostam desse conjunto?

\section{Caracterização do bairro}

- As pessoas gostam desse bairro?

- As pessoas têm amigos nesse lugar, conseguem desenvolver um bom relacionamento familiar?

- 0 senhor consegue se divertir nesse lugar?

\section{Expectativas}

- Como o senhor acha que poderia ser seu bairro?

- Como o senhor acha que poderia ser sua casa?

- Como o senhor gostaria que fosse aqui no futuro?

\section{Participação}

- 0 senhor participa de alguma associação, de bairro, de trabalho (sindicato) ou religiosa?

- 0 pessoal daqui do conjunto é unido, luta por seus direitos?

- 0 que o senhor acha dos moradores participarem no planejamento das casas que são feitas através da prefeitura.

Para evitar constrangimentos e as falhas já apontadas na aplicação do roteiro teste, a escolha dos entrevistados se deu conforme a disponibilidade dos moradores observada quando das visitas nos conjuntos.

No caso do Cingapura Imigrantes, houve grande dificuldade em encontrar moradores que se propusessem a fazer a entrevista. Segundo a líder comunitária do conjunto, tal fato se deve ao medo reinante de repressão por parte do crime organizado.

No caso do Campanha Gaúcha, a primeira entrevista foi realizada de forma coletiva, conforme proposição dos moradores. Em outra ocasião, ainda foram realizadas uma série de pequenas entrevistas espontâneas.

\subsubsection{Apresentação de resultados da abordagem qualitativa.}

Os resultados são apresentados em 5 tópicos distintos, correspondendo cada um deles a uma perspectiva de análise apontada nos objetivos da pesquisa, para cada um dos conjuntos pesquisados:

\section{(1) Trajetória Habitacional}

Procura-se em primeiro lugar, caracterizar, segundo a ótica da população, o histórico dos problemas por ela enfrentados no que diz respeito à situação habitacional. Procura-se diagnosticar se existe clareza da existência dos problemas e do processo enfrentado até a atual situação de moradia, identificando os obstáculos encontrados e as formas de superação dos mesmos. 


\section{(2) Apropriação e Caracterização da Moradia}

Tenta-se investigar como foi o processo de apropriação da atual moradia, como esta refletiu nas relações sociais do entrevistado. Investigam-se também a percepção dos órgãos provedores de habitação e a relação dos moradores com estes órgãos.

\section{(3) Apropriação e Caracterização do Bairro.}

Em consonância com o tópico anterior, visa identificar a percepção do bairro pelos moradores e a relação que estes têm com o mesmo, além de investigar como se apropriaram do conjunto.

\section{(4) Expectativas, Iniciativas e Participação Social}

Procura-se identificar qual o atual estágio de organização social, e se 0 acesso à moradia tem alguma interferência nesse sentido. Através das expectativas de futuro dos moradores, procura-se investigar quais as transformações que o processo de acesso à moradia trouxe para a vida dessas pessoas e suas conseqüências.

\section{(5) Participação no Processo de Produção da Moradia}

Procura-se identificar quais os limites e as possibilidades da participação social dentro do processo de produção de moradia financiada pelo poder público.

\subsubsection{Entrevistas analisadas do mutirão Campanha Gaúcha}

\section{(1) Trajetória Habitacional}

A condição habitacional da maioria dos moradores do Conjunto Campanha Gaúcha antes de se engajarem no Movimento por Moradia era a casa de aluguel:

\footnotetext{
"Nasci em Guarulhos,em 1959, e morei todo tempo da minha vida no Jardim São Pedro, aqui em Guaianazes, mesmo. De 1956 pra 1987 eu meu casei e a gente foi morar de aluguel, aqui mesmo, no Jardim São Pedro..."

"...morava na Parada 15, pagava aluguel e tal,e comecei participando na Igreja São Francisco, lá na Cidade Líder...".
}

Havia também os que moravam em favela, embora em menor quantidade.

"A primeira casa foi feita em uma semana pra um morador que perdeu a mulher e ficou com 7 filhos pequenos, e ele estava começando aqui no mutirão e não tinha condições. Ele morava num barranco que passava até córrego. Na época era uma barranqueira que dava até medo..."

Antes de começar o processo de viabilização do mutirão Campanha Gaúcha, os envolvidos já participavam de alguma forma do Movimento de Moradia.

"Nós ficamos mais ou menos uns três anos participando. Eu e um número imenso de pessoas. Isso já foi em 91 mais ou menos. Eu comecei mais ou menos em 90. A gente foi participando e tal e naquela expectativa quando eu vim aqui, foi em 90 acho que 92, eu vim aqui conhecer, eu cheguei aqui, eu me apaixonei..."

"A gente soube do Movimento através da minha tia.Minha tia tinha o intento de conseguir uma casa pelo Movimento Sem-Terra , inclusive,a área do Jardim São Paulo 
era área da Suzuki, uma empresa,... E ai nós fomos lá, minha esposa falou: 'vamos lá dar uma olhada, ver como é que é, né ?' Então, o mutirão deles, tinha um terreno, era um cômodo só, no fundo do cômodo tinha uma divisão, de um lado era a cozinha, do outro lado era banheiro e tinha um terreno no fundo que dava pra construir, só que já tava preenchida as vagas e aí indicaram a gente pra vir para a Igreja no Jardim São Pedro, que lá tinha Movimento de Sem-Terra...".

0 começo da história do Movimento de Moradia é descrito pelos entrevistados como uma luta difícil, repreendida com violência e sem reconhecimento de causa pela sociedade como um todo.

"Na época, a grande parte do Movimento tava empenhado em fazer um trabalho de política pra Luiza Erundina. Então a gente pegou uma época boa. Porque o Movimento, já tinha parado aquele negócio de invasão de terrenos, pauladas na Avenida Paulista, esse tipo de coisa, né, e a gente pegou uma época mais maneira, de negociação, mesmo. Acho que o prefeito, na época, era o Jânio Quadros e a idéia dele era desvincular totalmente o Movimento, quebrar as pernas do Movimento também; tanto é que o Movimento pleiteava uma área aqui no Jardim Santa Rita, próximo, e ele, ao invés de dar autonomia para o Movimento, separar as famílias e dar direito a elas, ele deu foi escritura e, posteriormente, sempre voltaram para o Movimento, porque ficaram sem nada. Tinham a escritura e podiam vender o terreno. Então ele desvinculou todo aquele trabalho que o Movimento pretendia fazer..."

"...durante a semana nós tínhamos corrido de cachorro, cavalo sei lá, tinham tocado animal em cima da gente, a gente corria muito. Naquela época o movimento de moradia, principalmente o pessoal do movimento, era tido como baderneiro mesmo. Nós não tínhamos aquele respeito dentro da cidade e o pessoal geralmente montava as comissões e ganhava mais no grito pra ser atendido ...".

0 mutirão Campanha Gaúcha originou-se de uma série de articulações dentro do próprio Movimento de Moradia, envolvendo também questões político-partidárias, conforme explica o entrevistado:

"Mas pra gente chegar aqui, na Campanha Gaúcha, teve uma série de situações do
Movimento, interno, pra determinar quem vai comandar, quem vai estar comandado,
precisa de uma direção, pra onde que a gente vai, quem vai estar determinando. E, na
época, a gente era novo no Movimento. Eu e minha esposa saimos como coordenador
- a Alayde. E o quê que acontecia? Já tinha um problema com a Benedita, que era
coordenadora, porque ela estava em dois lados. E aí a gente participava, aqui. Da
comissão de Guaianazes, que era na Igreja Santa Cruz. Quem comandava lá era o José
Bezerra, e a parte de baixo era Fátima, da Sagrada família. E aí a gente foi chamando
na igreja do Jardim São Pedro, ela tinha 68 famílias. Parte dela já estava naquele
mutirão da Erundina, pelo Movimento Sem-Terra. Nessa época houve um atrito entre
o Movimento e a Benedita, aí ela deixou a gente como coordenador do Jardim São
Pedro, eu e a minha esposa. Tinha uns seis meses de Movimento e aquele monte de
família que a gente não conhecia direito, aquele monte de gente né, e então falou:
'Olha Edson, eu estou sendo pressionada pelo Movimento e vou ter que dar uma
posição de que lado eu vou ficar, ou pelo PMDB ou pelo PT. E a maioria das famílias
que estão comigo estão pelo PMDB, então eu vou continuar com eles e eu passo a
direção desse trabalho pra você e sua esposa'...."

A eleição da Prefeita Luiza Erundina deu força ao movimento que já era articulado, e então teve início o processo de viabilização do mutirão Campanha Gaúcha, em um clima político favorável.

"Quando entrou a Luiza Erundina, ele havia prometido mil lotes pra Leste II, e também outras áreas pra toda São Paulo, pra outros movimentos. Ela foi eleita e cumpriu, a aí a gente veio pra essa gleba aqui de nome Campanha Gaúcha." 
"Depois entrou a eleição, a Erundina ganhou e a área foi apresentada pra gente, porque, na época, quem estava coordenando todo esse trabalho era a Míriam e a Laila né, que eram de São Miguel; o Valfredo foi reeleito, ou foi eleito vereador né... Quer dizer, foi todo um trabalho que foi realmente muito legal. A gente acabou conhecendo todo o mundo do Movimento...",

"As famílias que participariam da construção vieram parte Cidade Líder de Itaquera e parte Guaianazes, num total de 128 familias."

Antes de começar a liberação de verbas por parte da Prefeitura houve um processo de articulação das famílias envolvidas, desenvolvido pela coordenação daquele mutirão que havia sido designada pelo Movimento de Moradia, em parceria com a Prefeitura Municipal de São Paulo.

"Então, é assim: aqui no Campanha Gaúcha entraram famílias que era da Cidade Líder e de Guaianazes, dois setores. Dois setores que eram mais próximos. Então a gente fez todo esse trabalho. As famílias da Cidade Líder vieram pra comunidade, que foi no Santa cruz, né? De Guaianazes, saíram de São Pedro e foram pra Santa Cruz, todas as pessoas escolhidas da região de Guaianazes foram todas para a região de Santa Cruz, e continuamos a luta junto a Secretaria de Habilitação, que na época era o Nabil, a Ermínia Maricato, e ai fomos se acertando. E quem coordenava na época, que trabalhava com os mutirões era o Reginaldo Ronconi, um cara muito legal, também. Aí, a gente foi se afinando, trabalhando, até que saiu a primeira verba."

Houve um processo de capacitação das famílias para o mutirão, orientado por uma central do Movimento de Moradia denominada Central de Entidades Populares - CEP, em conjunto com a assessoria técnica TETO contratada pelo mutirão.

"Então, começou-se a trabalhar a questão de assinar o convênio com a prefeitura, começou-se a trabalhar toda a questão da organização, pra orientar as famílias. Como trabalhar um canteiro, a comissão de compra, o almoxarifado, a segurança, como seria trabalhar esse dinheiro que viria."

A construção propriamente dita, foi regulamentada através de normas estabelecidas pelo Movimento de Moradia e também pela organização local do mutirão.

"É assim: existia um regulamento do Movimento, que seria a participação das famílias freqüentando as horas pedidas pelo mutirão, que seriam oito horas no sábado e oito horas nos domingos e feriados. Teria que vir pelo menos uma pessoa de cada família, de preferência, o marido; caso não o marido, poderia ser a esposa e, numa outra possibilidade, um filho maior de 16 anos. As faltas seriam pagas da seguinte maneira: a família que faltou, traria um voluntário na outra semana, pra cumprir as horas deixadas atrás - pagando eles ou não - e havendo, três faltas, elas deveriam ser excluídas do mutirão; então era assim, toda presença era necessária."

A importância da participação da mulher é reconhecida por todos os entrevistados como elemento fundamental para viabilização do mutirão.

"Na verdade, quando se iniciou todo esse processo de reunir as familias, quem vinha para as reuniões eram as mulheres. Sou franco a dizer, eu fui ao Movimento pro conta da minha esposa..."

"Olha minha fia, quem começou isso aqui foi a mulherada, meu marido mesmo, ficava avexado deu ir grávida nas reunião, depois ele só veio participar quando eu num tive mais jeito, fui ganhar neném e ele foi obrigado..."

"Quem acreditou nisso aqui primeiro foi as mulheres, depois é que a gente veio vindo, mas elas carregavam bloco e tudo. Tá vendo esse alicerce aí? Foi minha mulher que cavou o buraco pra fazer..." 
"Eu tinha um medo terrivel de mutirão. Eu ficava sempre à parte. Ouvia e tal, mas nunca entrava para discutir o assunto. Ficava lã, se vai, vamos, se não vai, fica, e assim foi. E aí, por intermédio da minha esposa é que a gente foi procurar. Aí eu falei pra ela: 'Olha, eu vou, mas se você for junto comigo. Sozinho eu não vou, nem amarrado!' Então ela se propôs a ir, tanto é que nós dois ficamos coordenadores."

"E ai começamos a tocar, então quer dizer, existem coisas que realmente cabe à mulher no Movimento, a maneira de tratar, de conversar, até com outras mulheres... $E$ tem também aquele negócio de o marido estar presente e achar que você tá falando demais. Então, se uma mulher tá falando é outra história, o entendimento é outro. $\mathrm{E}$ também existe o trabalho do homem, que tem que se impor realmente, a seguir os critérios. Então, a gente foi muito claro, pelo menos com o pessoal do mutirão aqui. $\mathrm{E}$ aí, o quê que acontece? A gente se propôs a fazer isso juntos. Então, quando reuniram pessoas na comunidade, vinham mais as mulheres...".

Até se chegar a uma coerência coletiva para fazer deslanchar tanto a construção como a união do grupo, houve atritos que foram contornados pela propensão à organização dentro do próprio grupo, conforme relata o entrevistado:

"...em maio, passou abril, maio, a gente conseguiu receber a segunda parcela. Aí, já entramos também comprando o restante do material e já reorganizamos. $E$ no primeiro dia que a gente veio pra cá, demarcou-se o local pra fazer o salão e um pouco começou à direita, outro começou à esquerda e, no final do dia, ninguém se encontrou. Era parede pra cá, parede pra lá, e ninguém se encontrou. Aí eu tive que ser autoritário. Eu falei assim: 'Vocês desmancham isso porque parece que estão igual ou pior do que eu. Se são profissional, ótimo, porque do jeito que vocês tão fazendo, eu também sou'. Aí eu falei assim: 'Reunião amanhã, às 8 horas, assembléia geral, pra discutir o que é que a gente vem fazer aqui realmente, porque parece que alguém tá querendo ir pro outro lado.' Aí, o pessoal ficou meio bravo comigo, foram todo mundo embora nervoso, mas limparam tudo o canteiro, deixaram tudo, inclusive, depois eu recebi algumas ameaças por conta disso. Mas eu falei assim: 'Ou a gente vem pra fazer ou então a gente não vai fazer nada, mas essa palhaçada a gente não vai fazer.' Então foi todo mundo embora nervoso, todo mundo. Quando chegou no outro dia, 8 horas da manhã, como era de costume na igreja, a gente entrava fazendo a oração do Pai Nosso, né? E pedindo a Deus muita paciência e muita calma, pra não perder o "fio da meada". E aí o quê que aconteceu? Junto com o Domingos, naquela tarde de sábado que a gente desfez tudo, aí eu falei : 'Olha, Domingos, a gente precisa montar alguma coisa pra determinar os grupos, tem muita gente, a gente não tá se acertando, né?' Aí, ele sugeriu que se dividisse 128 familias em seis grupos, e assim foi feito. Então, cada grupo a gente tirou dois coordenadores, dividimos as famílias e fizemos um grupo especial, que era o dos profissionais. Quem é o profissional de alguma coisa, fica naquele grupo. Aí nós passamos das 8 horas da manhã até as 2 horas da tarde encaixando as pessoas nos grupos. A gente foi almoçar à 1 hora e, quando voltamos às 2 horas, já tinha todos os grupos formados. Aí, eu falei assim: 'Quem é o pedreiro, quem é mestre de obras, quem é eletricista, quem é encanador, quem é isso, quem é aquilo outro...'. E então, por Deus, a gente tinha pelo menos uma pessoa de cada, aqui dentro do mutirão. Aí, às 3 horas, a gente já tinha formado o pessoal que ia trabalhar com o pedreiro, o pessoal que ia trabalhar com o encanador, com o eletricista e tudo mais. Era tudo anotado. Então, das 3 horas até as 7 horas, que o horário tava bom, a gente fez novamente a fundação do salão e deixamos com quatro fiadas de bloco, toda a extensão do salão. Foi uma alegria! Quando o pessoal viu as quatro fiadas de bloco lá, saindo do chão, cada uma se encontrando, aí eu falei assim: 'Olha, nós já estamos começando a se entender .."

As principais dificuldades enfrentadas no processo são apontadas a partir da eleição do prefeito Paulo Maluf.

"Então assim, a gente começou, aí fomos construindo, ai depois em 92 já no finalzinho do ano foi a passagem da política era a Erundina e ela tava fazendo o sucessor dela 
que seria o Suplicy entendeu, e a gente batalhou muito, muitas pessoas, eu principalmente que sempre fui assim, depois que impregnou esse espírito de luta em mim e a gente batalhou muito pra esse sucessor que seria o Suplicy, só que infelizmente nós tivemos o contrário, que foi o Maluf, que foi eleito e daí uma coisa que tava tudo certinho...".

Mesmo com a interrupção do repasse de verbas entre os anos 1992 e 1994, o mutirão não se desarticulou e, às custas dos próprios moradores, que acumularam durante um tempo os gastos com o aluguel e com a construção, conseguiram finalizar as 128 unidades habitacionais.

"O Maluf entrou e levou tudo para o Tribunal de Contas e todos os mutirões de São Paulo, que não eram poucos - na época se não me engano eram 82 mutirões - tudo para o Tribunal de Contas, porque, no entender dele, tinha desvio de verbas e daí foi feito toda uma investigação e nós aqui, graças a Deus saímos ilesos e não teve nada que desabonasse a diretoria daqui e daí isso ocorreu de 92 até mais ou menos 94, 95 e ele foi fazer o sucessor que era o Pitta, ele foi fazer o sucessor dele e em 95 já era a equipe do Pitta e foi inaugurado esse mutirão, foi a inauguração real, já tinha concluído, nós tiramos muito dinheiro. Eu, por exemplo, pagava aluguel e as casinhas foram as mais prejudicadas na época porque quando foi para o tribunal de contas, parou de repassar verbas, Ai faltavam as casinhas que estavam a maioria inacabada aí aquele que tava trabalhando, ganhava um pouquinho né, eu já fazia assim; eu comprava uma coisa, aí colocava, mas tinha que pagar aluguel, aí mês seguinte, a gente colocava uma coisinha, fomos fazendo assim, até que veio novamente a verba pra conclusão, a gente foi fazendo assim e não abandonou...".

Os mutirantes tiveram clareza do panorama político desfavorável, instalado com a eleição de Paulo Maluf, e continuaram se articulando mesmo dentro desse quadro.

"Quando terminou a gestão da Luiza Erundina, faltava pouco pra terminarmos. Na verdade faltou muito pouco, faltou 30 unidades pra realmente terminar e inaugurar isso daqui. 0 problema é que, se não me falha a memória, foi em março de 1991 ou 1992 que o Tribunal de Contas vetou as contas da Erundina. E aí ficou, aço, que dois a três meses sem enviar verba pra ninguém, por causa da prestação de contas e quer era o presidente do Tribunal, na época, acho que era Eurico Sales, malufista roxo! Então, junto com a família do Maluf, eles tavam doidos pra brecar o processo."

\section{(2) Apropriação e Caracterização da Moradia}

Com relação à unidade habitacional, os entrevistados falam com orgulho e propriedade das casas de $60 \mathrm{~m}^{2}$.

"...um palácio, comparado com a casa de onde eu vim."

"Aqui temos 128 casas, todas de 60 metros quadrados. Na avenida são 20 unidades que é sobreposta. Mas as medidas são as mesmas, o terreno é 3,60 metros de largura e 20 metros de comprimento, enfim, acho que o único mal que houve, realmente, foi o político, né..."

0 processo de transição no caso do mutirão, de sair da casa alugada e ir para casa construída em todos os sentidos com a participação do próprio, é relatado com alegria, mesmo tendo a maioria das famílias mudado antes de terminar a obra. Mais do que a casa nova, a cooperação entre vizinhos foi considerada como o grande ganho.

"Eu hoje tenho minha casa, que nem, qualquer um que viajar o vizinho vai cuidar melhor do que o dono..."

"Depois de feita a Quadra A, não tinha água nem luz, tinha apenas aquilo que era ligado pra construção. Então a gente puxava os fios da primeira rua da igreja pra atender as famílias, né? Então eles não podiam ligar geladeira, não podiam ligar 
chuveiro, senão caía a rede. Para a água, a gente puxou uma mangueira enorme, os canos ao por baixo da calçada, colocamos uma torneira no centro e, pra encher as caixas, o pessoal tinha que encher os baldes, encher as caixas... Era uma coisa de louco. Mas tinha um lance muito legal. 0 pessoal era tão unido, que eles mesmos se ajudavam! Vamos supor, eu não ia pegar o meu balde, você não ia pegar o seu balde, eu vou lá com você, a gente enche os baldes, você enche a sua, depois você vem, enche os baldes, enche a dela, era uma coisa muito legal! E assim, depois que a gente terminou que seria, tantas casas, enchia a caixa hoje e tantas casas enchia a caixa amanhã, pra não ter todo mundo no mesmo dia, né?.".

0 motivo que levou algumas pessoas a transferirem o direito de posse da casa para terceiros geralmente foi a morte do possuidor original da casa ou a transferência, mesmo que em vida, para outros membros da família. Esse processo, feito informalmente, também é organizado pela associação de moradores.

"Esse é o Francisco ele entrou em 2001, eles são moradores novos, pessoas que moraram aqui e por um motivo ou por outro resolveram passar a casa pra frente. Foram mais ou menos umas 20 casas, foi pouco, já teve muitos casos que a mãe faleceu e ficou pro filho, a maioria tem as declarações. Essa declaração a gente reconhece firma e passa pra $\mathrm{COHAB}$. São três vias; uma fica com o morador, outra com a associação e outra com a $C O H A B$. Todas as vezes que tem um repasse de casas, porque, eles fazem um contrato de gaveta, separadamente a diretoria informa a $\mathrm{COHAB}$ que a casa foi passada, a gente tem o hábito desde a outro presidente, aqui tem declarações, listas de presença, tem outros casos em que a mãe passa para um filho diretamente ela está viva ainda, então a gente tem tudo isso guardado...."

\section{(3) Apropriação e Caracterização do Bairro}

A apropriação do conjunto pelo bairro demandou tempo e gerou alguns conflitos, mas foi superada e o diálogo com a população do bairro hoje é considerado amistoso.

"Num sábado, eu vinha sozinho e duas pessoas me parou e falou: 'Olha aí, o dono do terreno tá chegando, mas a gente vai dar um jeito nisso.' E eu disse apenas: 'Querem tentar a sorte, né...'. E aí eles partiram pra agressão. Eu quase levei a pior. Aí apareceu um pessoal do mutirão. Eles não me machucaram e não foi nada tão grave. Mas, por precaução, a gente fez um Boletim de Ocorrência e denunciamos. Mas não deu em nada. E depois o pessoal foi entendendo que aqui ia ser construído casas e não favela, e a gente... Quem era ruim começou a se afastar, porque já não dava mais pra eles, e a gente teve uma convivência melhor. E hoje a população inteira deles participa junto com a gente aqui dentro, tem a entrega do leite, muitas famílias daqui recebem leite junto com a Associação... Quer dizer, realmente mudou a situação da gente aqui em Guaianazes."

Passados 12 anos da inauguração do conjunto, ele está integrado ao entorno na opinião dos entrevistados. 0 bairro aparece nos relatos como um lugar agradável e bom de se viver.

"Nós temos toda a facilidade por aqui. Se nós analisarmos também por outro ângulo, nós temos padaria, supermercado, farmácia, hospitais, escola, creche, posto de saúde, atrás aqui nós temos um CEU enorme, trem espanhol que é muito bom, temos o Extra aqui na frente, tem que dar a volta, quer dizer acho que a está em termos de estrutura de bairro a gente está bem servido. Veja, eu não canso de vim, a minha filha mora lá em cima quatro ruas daqui vem meia noite, meia noite e pouco da casa dela e ninguém nunca mexeu comigo. Então eu acho esse lugar aqui tranqüilo em vista de outros lugares..."

A boa relação no conjunto, assim como a permanência dos moradores originais, permitiu o desenvolvimento das relações sociais no conjunto, mesmo depois do final da obra. 
"Assim, a Lu é comadre da Nice. Aqui tem moças que casaram com rapazes então tem gente aqui dentro que constituíram outra família aqui dentro. Então assim, não tem aquela coisa de briga, só aquela coisa, quando o homem enche a cara, que tá no boteco, mas é coisa assim, não aquela coisa de morte, não graças a Deus..."

"Nós fizemos uma quermesse, sabe nunca tinha sido feito. Nós fizemos uma quermesse no mês de julho. Eu morri de medo porque, além do pessoal do conjunto, veio o pessoal de fora. Nós temos 140 famílias do leite essas pessoas também vieram, mas foi uma beleza, deu tudo certo."

Como demonstração da integração do conjunto com o bairro, os entrevistados citam o Programa Leve-Leite, que foi uma iniciativa da Associação dos Moradores do Conjunto Campanha Gaúcha para atender às famílias do bairro.

"Elas participam só do programa do leite; por enquanto só do leite... Eu, pra mim, não tem o que falar. Nosso relacionamento que nem o do leite nós temos 140 famílias, então 20 são daqui de dentro e 120 são de lá de fora, onde a gente anda e é respeitado."

Alguns moradores se mostram incomodados com o uso de drogas por parte dos jovens do conjunto e da vizinhança, que usam o espaço do conjunto para tal. Motivo que leva os moradores a querer fechar uma das entradas de acesso ao Conjunto.

"0 problema que a gente está enfrentando, que a gente está tentando um solução sem que prejudique alguém, é porque e assim aqui nós temos uma passagem e é uma passagem oficial. A gente, pra poder fechar, tem que ter uma autorização da Subprefeitura, um abaixo assinado com documentos, né, e com documentos pra poder fechar. Então o pessoal entra, passam aqui por trás dessa mangueira e encostam aqui e fumam maconha, ou então encostam naquela pracinha e fumam, mas infelizmente tem meninos daqui de dentro que fazem o uso. Eles não mexem com ninguém."

\section{(4) Expectativas, Iniciativas e Participação Social}

Mesmo 12 anos depois de concluídas as obras do mutirão, a participação dos moradores do conjunto na Associação de Moradores do Conjunto Campanha Gaúcha é maciça. Em todos os depoimentos, os entrevistados mostraram coerência em relação à consciência dos problemas enfrentados e aos meios possiveis para solucioná-los.

"É uma família, dá impressão que está todo mundo disperso, todo mundo trabalha, tem seu cotidiano, mais assim, no momento que a gente acionar a sirene, começa o povo a vim querer saber o que acontece. Aí a gente fala: está acontecendo isso e isso o povo fecha, entendeu? É assim se a gente chamar e assim, graças a Deus, a gente está batalhando, está correndo juntos ainda..."

Muitos também admitem que a união do começo do grupo, quando da construção das casas era maior do que é agora.

"Tinha gente que a gente trabalhava aqui e comia os dois na mesma marmita. Hoje, passa por você e nem te cumprimenta, não te conhece..., mas tem mais gente boa do que ruim..."

"Eu acho que aqui o pessoal passou a respeitar mais o outro, a dar um pouco mais de valor pro seu vizinho, a aqueles que realmente merecem, e tem algum que a gente passa a conhecer as pessoas boas e as pessoas ruins, então as pessoas boas você vai querer ajudar. Então você aprende a reconhecer umas coisas, antigamente não, a gente achava que todo mundo era igual..". 
"Então, por exemplo, uma união que existia no principio, hoje já não existe mais. As pessoas tavam se vendo como inimigas até, entendeu? E isso foi difícil pra gente manter... Tanto é que nós perdemos muita coisa, desanimou muitas famílias, a própria situação do país...".

0 fato de eles permanecerem unidos e participando ativamente é atribuído ao processo pelo qual passaram até chegar à moradia.

"Olha minha filha, eu passei por 6 anos de aula antes começar o mutirão. É, foi isso mesmo, 6 anos antes que começar. Então, quando nos viemos pra cá, eu já tava educada entende, nos todo mundo tava educado já..."

Quanto ao futuro da Associação, ele é discutido de forma prática, calcado na realidade atual e ciente das limitações. Há intenção de promover melhorias para o conjunto e para 0 bairro através da inserção de novos programas na comunidade, principalmente na sede da Associação.

\begin{abstract}
"Porque é assim, a gente está preiteando, a gente está tentando trazer alguns projetos pra cá, a gente ainda não conseguiu. Não sei o que acontece, mas a gente ainda não pegou os caminhos certos estamos pisando em pedras e quando a gente pega os caminhos das pedras ...",

"Se eu ganhasse na loteria, primeiro eu compraria de vez todas essas casas pro povo parar de sofrer, depois eu ia deixar esse lugar aqui [o centro comunitário] uma maravilha..."

"Ah seu ganhasse na loteria, precisava ser muito não, uns 250, 240 mil, eu reformava isso aqui que você ia vê só, eu ia por uma cozinha..."

"Eu, na verdade, o que eu espero pro futuro, o que a gente precisa é um pouco mais de segurança. A gente precisa aqui urgentemente é assinar o nosso contrato pra dar uma segurança, mas o que a gente precisa não é muito. A gente precisa terminar a nossa associação deixar ela mais bonita. Fazer a nossa quadra para os nossos jovens, trazer projetos pra cá. Nós temos muito espaço, mas não temos nada, porque eu não sei o que acontece e que a gente não consegue. Não sei se é política, mas a gente não consegue. É uma burocracia muito grande, mas assim, em perspectiva de vida, é conseguir que nossos jovens consigam crescer, fazendo uma faculdade, fazendo cursos profissionalizantes e que a gente pudesse ajudar, que a entidade tivesse essa força. Do tipo, eu conheço uma entidade que eles têm uma estrutura assim que eles conseguem caminhar e a gente não consegue nada ..."
\end{abstract}

Se, por um lado, o problema de não ter a posse definitiva das casas cause desmotivação nas pessoas, por outro, o problema que vem desde o começo do mutirão promoveu uma articulação com outros mutirões na mesma situação para tentar resolver a questão coletivamente.

"Foi a luta do Edílson, saiu da presidência e entrou o Edson, é uma pessoa também muito sensata, fez muito aqui dentro e a gente ficou no aguardo do contrato. Todas as vezes que a COHAB chamava, ou na época do Edílson ou na época do Edson, eles ofereciam uma permissão de uso e permissão de uso eu e o pessoal aqui dentro, a gente encara como um aluguel social. Então sempre foi falado pra COHAB: regulariza, porque a $\mathrm{COHAB}$ alegava que não podia oferecer o contrato de compra e venda porque o lugar não era regularizado e a gente sempre bateu nisso. Não sou eu mais os outro presidente regulariza que a gente assina... Então a documentação está da seguinte forma, nós fomos chamados em fevereiro pelo Valter Abraão, que é o superintendente da COHAB e falou pra mim: 'Vamos assinar permissão de uso onerosa e opção de compra.' Falei: 'Valter, não adianta você me dizer que permissão de uso oneroso e opção de compra é diferente, não adianta, não vai entrar na minha cabeça eu não vou 
pagar aluguel, eu vim pra cá pra ser dona, não quero pagar só bloco, eu quero pagar a terra e a permissão de uso. Você só poderia assinar um contrato de compra e venda quando regularizasse a terra. Agora, eu não sei, você há de raciocinar comigo: em 15 anos não regularizou nossa terra. A partir do momento que assinarmos uma permissão de uso, a COHAB vai se preocupar em regularizar?' Certo, então assim ficou esse impasse com a COHAB e a gente. Aí, um dia, o Valter ligou e disse: 'Izildinha, regularizou a sua área.' Assim do nada, falei: 'Oh, maravilha! 0 que você vai oferecer pra gente?' 'Vou oferecer um contrato de compra e venda.' Eu falei assim: 'Você falava pra gente, não sei se você conheceu o Programa de Subsídio Habitacional o PSH, corri muito atrás desse programa mesmo antes de ser presidente aqui, quando eu fiquei sabendo que tinha esse programa na cidade me juntei com a Marizete que é presidente do Fórum de Mutirões e fui até a $C O H A B$, participei de uma reunião com o Valter. Quando algumas áreas estavam sendo fechadas, falei pra ele: 'Faz isso lá pro Campanha Gaúcha?' Ele disse: 'Não pode; lá não está regularizado. Quando a área não está regularizada, não há subsídio do governo federal, porque as empresas não aceitavam área não regularizada.' Não porque no início era esse aqui o contrato de 92 perdeu o efeito lega. Esse praticamente era o contrato. Então aí ficamos nessa caminhada. E queremos pagar a $\mathrm{COHAB}$, nós sempre deixamos claro pra $\mathrm{COHAB}$. Não só eu, como os outros presidentes, que a gente quer pagar, todo mundo quer pagar, porque que você pague aquilo que você adquiriu, mas que seja seu. Eu não vou pagar a permissão de uso porque lá adiante, se eu precisar do financiamento da Caixa Econômica e disser eu tenho uma casa, mas é mutirão e só tenho um contrato de permissão de uso, ele vai falar pra mim: 'Não, você não tem é nada, porque, na verdade, a casa é da Prefeitura, da COHAB. 0 que no início, há muitos anos atrás, quando começou a história do contrato e sempre se bateu em cima disso, eles falavam assim: 'A área não se regularizou porque a prefeitura não passou para a $C O H A B$ ' $e$ chegaram até a falar que, para se regularizar, tinha que passar por um projeto de lei na Câmara Municipal. Aí eu falei assim, no ano passado pro pessoal da COHAB, 'Se é pra passar por um projeto lei, é necessário que nós façamos um movimento na porta da Câmara? Falei porque, se for por isso, eu vou juntar meu povo e venho pra cá. São 128 famílias, e cada família não tem menos de 4 pessoas na residência. Tem casa aí que cada família não tem menos de 10 a 15 pessoas na residência. Então você imagina, junta pelo menos a metade das pessoas e ir para frente da Câmara Municipal. Então eles falaram que não que não tinha necessidade. Aí vai reunião aqui, reunião ali, e daí, quando foi em abril, em maio ele me falou que a área tinha sido regularizada. Aí eu até tinha feito uma declaração para o $3^{\circ}$. Cartório, informando que a área estava concluída em regime de mutirão, que não tinha essa declaração lá, eu fiz a declaração tal, reconheci firma e a COHAB encaminhou e o mês passado, em junho, que nós tivemos lá; no dia 22 de junho, não me recordo o dia, e eles falaram que a regularização estaria saindo no dia 23 de junho. Já saindo do $3^{\circ}$ cartório, eu tinha feito um pedido pra $\mathrm{COHAB}$ pedindo uns esclarecimentos. Porque é assim, tem coisa que a gente não consegue responder para o morador, porque têm coisas que a gente da diretoria, a gente corre atrás das pessoas mas não vê o resultado. Tem gente que fala que não vai na assembléia porque não vê resultado, porque a gente faz assembléia aqui todo primeiro domingo do mês tem assembléia às 9 horas da manhã, a gente faz assembléia eu aciono a sirene e o povo vem."

\section{(5) Participação no Processo de Produção da Moradia}

Há um nível avançado de percepção do processo de acesso a moradia, do qual eles participaram.

"A gente mostrou pra São Paulo, pra quem quisesse ver, que o mutirão dá certo... 0 Maluf declarou uma época que essas casas não eram pra pobre... Então, o que é pra pobre? Barraco? Acho que é isso que ele entende que é pobre, mas a gente realmente fez um trabalho que eles deveriam ter feito. Eu tiro meu chapéu pra Luiza Erundina, na época, por ter entendido que o povo realmente precisava de uma mão só, eles deram e o povo atendeu às expectativas do Movimento, atendemos ao propósito do mutirão..." 
"Foi a autogestão que possibilitou a gente a fazer o que a gente fez...".

Essa percepção clara do processo leva a um entendimento amplo da questão habitacional e das responsabilidades do poder público na produção de moradia, como pode ser percebido através dos depoimentos transcritos a seguir.

"É um programa de governo mal estruturado [o Cingapura], porque se tivesse uma preparação do povo antes..."

"Eu acho que a diferença entre o Cingapura e o mutirante é que o mutirante, ele é um trabalhador que não consegue ter a sua casa, e o favelado já vem com aquele ciclo vicioso, monta barraco, vende barraco, eles vendem aleatoriamente, se não tiver vai pra debaixo da ponte. 0 mutirante trabalhou, ganhou dinheiro, mas não conseguiu ter seu lar. E foi através do suor que ele conseguiu construir a casa. Deu seu suor, chegou até a pessoas a morrer, morrer assim, de acidente. Pessoas que sofreu do coração, como a primeira moradora a dona Elsa. Ela tava vindo pra cá e..."

"Pelo sistema criado e tudo mais, eu acho que, infelizmente, por conta da política, perdeu-se um grande braço que poderia não salvar o mundo, mas, com certeza, atenderia muito mais gente do que a $\mathrm{COHAB}$ atende hoje com o Cingapura. Então, esse era o intento do mutirão com autogestão. Em todo sistema há falhas. Nesse também houve, mas uma coisa é certa, não ficou melhor por conta da política..."

"Eu acho que se deixassem o mutirão fazer tudo aquilo que ele pode, eu acho que a $\mathrm{COHAB}$ ia ter que fazer... ia ter que recriar uma outra maneira de determinar habitação popular, entendeu? Porque, com certeza, os mutirões com autogestão taparia ela de um jeito que esse órgão não ia ter porque."

Também foram discutidos outros Programas Habitacionais, como o PAR:

"... por exemplo, agora a COHAB tá fazendo aqui [na Zona Leste] uns conjuntos do PAR, sabe qual é? Pois é, e ainda quer dizer que aquilo é pra pobre. Se eles coloca um monte de coisa que o sujeito tem que comprovar, uma renda altíssima, não pode ter restrição nenhuma. Onde já se viu pobre que não tem restrição? Aí, pra solucionar 0 problema, eles vai lá e faz o tal de PAR 2, que a renda é alta também, só que o prédio é pior, quer dizer, num adianta, porque o sujeito entra ali e aquilo pra ele não é dele. No PAR, acho que é assim: o sujeito entra e depois de 15 anos pagando ele tem a opção de compra, num é?"

"...ali em cima tem um conjunto, Chácara das Flores, num o que que é, CDHU, não sei. Eu mandei minha filha ver como era. É até bonito por fora, mas já tá uma baderna, porque é um entra e saí de morador. Os primeiros que entraram já saíram, venderam o direito...".

E também o mutirão da CDHU:

"Aquilo é uma baderna, [mutirão CDHU]. Não sei te dizer porque, meu irmão participa lá e não é organizado e bonitinho que nem o nosso, será porque comadre?"

\subsubsection{Entrevistas Analisadas do Cingapura Imigrantes}

\section{(1) Trajetória Habitacional}

A trajetória habitacional descrita pelos entrevistados começa sempre com a casa de aluguel:

"Pra chegar aqui no lugar onde eu tô morando? Primeiro eu fui morar, pagava aluguel lá, mas não deu certo..."

A casa de aluguel foi a primeira opção de moradia também para os migrantes: 
"Meu marido veio primeiro aqui pra São Paulo, deixou eu lá na Bahia, com meus filhos, depois ele mandou me buscar, só que chegou aqui e ele ficou desempregado logo. Aí nós ficou numa situação difícil, não tinha condição de pagar aluguel..."

E para uma geração nascida na favela:

"Eu nasci aqui em São Paulo, no Jabaquara, nasci em uma favela. Sempre fui agraciada por morar em favela, só que no Jabaquara tinha enchente.. Então, a gente sofria muito com a enchente. Quando eu casei, a gente foi morar de aluguel. Mudei várias vezes, nem sei quantas casas realmente eu morei, até que eu parei em Vila Clara, divisa de Diadema. Ali, eu morava em uma casa, pagava o valor de aluguel, era um barraco de madeira, então era muito difícil porque o banheiro era fora. Na época, a gente tinha uns traficantes muito folgados porque eles pulavam no quintal da gente pra usar. Então tinha noite que eu tinha que fazer xixi no pinico porque eu não podia ir no meu banheiro... Aí nós tivemos que sair dessa casa porque o aluguel subiu muito, isso há treze, quatorze anos atrás. Aí eu fui pagar aluguel num sobrado lá na mesma região, só que era perto de um cano assim daquele esgoto que aquilo descia água parecendo uma cachoeira. Aquele barulho tava me enlouquecendo... Ai calhou que ele ficou desempregado e eu também, então a gente passou uns momentos super difíceis né."

Para os entrevistados, a experiência com o aluguel deixou bastante a desejar. Depois, por conseqüência do desemprego, a alternativa mais viável foi o barraco na favela. A situação de ficar de "favor" na casa de parentes, é preterida em relação ao barraco na favela.

"Fomos morar com meu irmão e sabe como é, ele começou a reclamar que a gente tinha que pagar e a gente não tinha dinheiro. Ai ele tinha um irmão que morava aqui na favela, aí ele foi lá, disse se a gente não queria morar aqui na favela. Aí nós compramo um barraquinho e viemos. Era um barraquinho de tábua pequenininho, depois ele arrumou um serviço, mas um serviço que não tinha condições de pagar aluguel, água, luz..."

Mesmo em condições nefastas, o barraco na favela constituiu uma estratégia de sobrevivência em um período de condições de trabalho precárias, empregos temporários e mal remunerados.

"Fui eu com a velhinha lá, fizemos o barraco lá. Foi... Chegou um dia, o dono do terreno apareceu, quis o terreno, ai naquele dia pagou o quê? ... 250 real. Pagou 250. Foi quando a gente localizou um lugar aqui em baixo, aqui no Tapajós e eu vim. Comprei e passei a morar no barraco. 0 barraco chovia lá fora pingava dentro. Aí fui arrumando devagar..."

"Aí ele veio trabalhar, a empresa dele é que veio construir esses prédios. Então ele conheceu um rapaz que tinha um barraco aqui na favela. Então ele tava querendo vender, só que a gente não tinha nem um centavo, a gente não tinha dinheiro nem pra comer, foi um momento muito difícil né."

Existia uma rede de confiança estabelecida na favela, que facilitava a aquisição dos barracos.

"Até que a gente negociou com esse rapaz a TV que a gente tinha. A gente daria a TV e iria pagando as prestação pra ele... Então nós viemos morar num barraco de uns cinco metros. Fizemos um banheirinho, tal. A cozinha era isso, tá vendo daqui pra ali? Era isso. Eu conseguia me mexer porque eu era mais magra, né."

"Foi quando construiu um barraco lá no fundo, lá perto do Cecilio e a Conceição. E aí a gente foi indo devagar. Conhecimento com um e com o outro. Aí, foi quando eu conheci um rapaz amigo meu e o cara queria vender o barraco pra ir embora pra Minas e falou o seguinte: 'vou receber o dinheiro amanhã, mas você pode deixar ele 
passar pra dentro, eu assino embaixo.' 0 cara confiou em mim e na palavra de outro colega que já conhecia ele. Num belo dia; já tava dentro do barraco, já pra morar."

Foi nesse estágio da trajetória habitacional, por volta de 1994, quando a situação econômica recessiva do país aliada ao desemprego massivo trouxeram graves conseqüências para as condições de moradia da população, que surge o Projeto Cingapura na vida dessas pessoas. 0 processo de sair do barraco e entrar no apartamento foi penoso, sem maiores cuidados.

"Nessa história toda, tiraram o barraco nosso e nós fomos morar no alojamento. Ficamos um ano no alojamento mais ou menos. Aí, depois a gente veio pro prédio... Então, pra mim, foi uma trajetória super complicada porque no alojamento o vizinho que morava do lado, ele era usuário de drogas né. Então toda noite eu tinha que por uma bacia de água em cima da mesa para agüentar dormir porque o cheiro era muito forte."

"Quando foi um belo dia, a prefeitura apareceu fazendo o cadastramento. Nem fui eu que fiz, foi a mulher. Aí fizemos o cadastramento, esperemo, apareceu os apartamentos. Ai nós aguardemos, passemo a morar aqui.

A comunidade não participou de nenhuma decisão, nem a respeito do modo como foi elaborado o programa, tão pouco a respeito de questões mais especificas, como o alojamento comunitário por exemplo. Muitos não queriam ir, mas foram obrigados, já que seus barracos seriam destruídos. A saída para quem não se adequou foi vender o seu direito.

"Nunca fomos consultados, de jeito nenhum. Quando chegaram, já desocuparam uma turma, botaram a turma pro alojamento, que era ali. Não consultaram ninguém. Mandou nós aguardar, que a gente já tinha feito o cadastramento, uma hora ia aparecer uns barracos. Muitos foi para ali. Eu não cheguei a ir não, porque eu dei sorte. Quando era para ir para ali, saiu o apartamento ali, que o cara tinha vendido a parte dele, o cara que é ... não pode vender né..., ai vendeu, o cara descobriu que não tinha condições pra outro, no lugar do cara fui eu morar."

Apesar dos trâmites impostos pela prefeitura, as pessoas afirmam estarem em melhor situação, principalmente de salubridade do que na moradia anterior.

"Foi aí que veio o projeto do Maluf né, não é que melhorou nem piorou pra mim , melhorou, melhorou aqui dentro, mas acho que ele tinha que terminar..."

"Melhorar, melhorou. Antes tinha rato, agora tem só barata..."

"Tá beleza! Pra onde nós viemo, tá beleza demais!"

"A mudança que a gente sente da favela pra cá é que assim: é que na favela, a gente tinha muito problema com o calor. Era essa telha, como chama? Brasilit? Quando chovia, por exemplo, era um perigo do vento vir forte e arrancar tudo. Então a gente não tinha equilibrio. No calor era muito quente, no frio era muito frio. Dormi muito tempo no chão porque não cabia. Eu tive que montar o beliche, pus os meus filhos pra dormir no beliche e eu no chão, porque não tinha espaço. Era super complicado. Então a mudança pra cá, pra mim, foi bom, né. Porque hoje eu tenho meu quarto, eu fecho a minha porta, e não me enchem o saco, né."

Em sobreposição ao programa habitacional que produziu os Cingapuras, os moradores reconhecem, antes de tudo, a figura do ex-prefeito Paulo Salim Maluf como o executor da tarefa. 
"É o seguinte, o conjunto foi feito pelo Maluf. O Maluf nós paga por mês o boleto que é de 57,00. Nós paga água, paga luz, a luz dentro de casa e ajuda na luz da estrada, da administração."

Alguma articulação por parte da população, ainda que de forma fragmentada, propiciou a manutenção de alguns dos vínculos sociais existentes na favela.

"Aí aqui no prédio, como a gente sempre participou. A gente é meio capeta, né. Eu sempre participei das coisas. Então, a gente organizou uma lista e ó: tá aqui, se puder colocar a gente gostaria, porque são pessoas que já conviviam na favela. Então a gente conseguiu pelo menos nesse andar, no debaixo e no de cima, colocar pessoas que a gente já se conhecia. Nesse prédio, a familia que deu problema era a que a gente não conhecia."

Porém, a falta de planejamento, ou até mesmo de critério para escolher as pessoas que iriam ocupar os apartamentos é apontada pelos moradores, como uma falha do programa.

"Acho que na hora ele tinha que fazer uma pesquisa pra saber quem tinha condições de pagar, porque a água, por exemplo, dá trabalho. Ninguém quer pagar. Eu e ela paga pra muitos que nunca pagou, acha que é tudo de graça, que nem no barraco, mas não é. Aqui é diferente..."

\section{(2) Apropriação e Caracterização da Moradia}

Se, por um lado, a vida melhorou mudando do barraco para o apartamento, por outro, ela se tornou mais complicada. No barraco, as relações de propriedade, embora informais, eram claras e respeitadas. Ao mudar para o apartamento, sem um contrato, ou qualquer tipo de esclarecimento, o vínculo de propriedade com o mesmo se revelou confuso e prejudicial para 0 planejamento da vida das pessoas.

"Nós paga 57,00, mas não sabe até quando, se um dia nós vai ter direito. Que nem, nós mora aqui, mas nós não pode falar que nós têm direito, que nós pode vender. Que nem na prefeitura falaram que nos não pode vender, não pode fazer nada, tem que ficar aqui o resto da vida?"

"... mas, com relação à documentação, o jeito que foi é meio difícil para nós. A gente queria um dia ter o documento, porque na CDHU o pessoal tem escritura, né. Por que a gente não pode ter?"

Os problemas de administração de condomínio em uma comunidade que não optou por essa modalidade de moradia e que é muito pouco mobilizada para resolver seus problemas, além de ser "controlada" pelo crime organizado, tornam-se evidentes.

"Olha, pra mim, que venho do aluguel, que sempre tive que viver com dificuldades, tá ótimo. Mas vai ter gente que vai te falar o contrário, porque agora ele tem que pagá, pagá, pagá."

"A gente não paga muito, é 57 reais. Então, mais ou menos, por mês fica uns 130 reais, a luz do prédio, manter a bomba de água ali de fora. É difícil, faz o rateio, 30 reais por apartamento. Aí a gente paga conta de água, conta de luz. A maioria paga. Depois que você desligar eu te falo..."

"Eu acho que desse jeito que tá, eu não sou contra o cara que não paga, mas não pagou nada ainda vai ser ruim pra eles né, vai tomar. Pra CDHU, é o mesmo grupo, pra $\mathrm{HABI}$ eu acho, o bicho vai pegar. Agora eles fecharam os bons, não sou contra todo mundo precisa, mas deixaram os bons lá dentro e trouxeram os mal pagador pra cá, aí a coisa não vai pra frente." 
A mobilidade no conjunto é grande, os contratos de gaveta, permitem que as pessoas renegociem de forma precária o apartamento. 0 destino dos que saem geralmente é o de retorno à cidade natal, ou mesmo a condição anterior do barraco na mesma favela

\begin{abstract}
"Assim a gente tem um termo de permissão de uso, a gente pode usar o apartamento pra morar, a gente não pode vender nem nada. Agora muita gente vai lá e faz aquele contrato de gaveta lá e se muda. Então só aqui no nosso prédio que é dos que menos saiu gente, nós temos morador novo nos apartamentos $14,11,23,43$ e no 22 e no 34 . Um voltou pra Minas, outro pra Bahia, ...".
\end{abstract}

Quanto à unidade habitacional, apesar das famílias numerosas, o espaço disponível não foi motivo de grandes queixas. As mais contundentes são com relação à área de serviço e ao lavatório, que foi colocado de fora do banheiro.

"Eu acho assim, que nossa cozinha, pelo formato que ela é, ela podia ser um pouquinho mais gordinha, pelo menos pra gente poder passar, entendeu? Acho também que a área de serviço é muito pequena. A gente põe a maquina de lavar e sobra quase nada de espaço pra gente estender a roupa. A sala pra mim tá ótima e a pia pra fora, né, seria muito bom se ela estivesse dentro do banheiro. A pia por fora não resolve nada, eu acho que seria melhor a pia dentro do banheiro né."

A par dos estereótipos existentes a respeito da população favelada, a população moradora dos prédios ainda se considera como tal.

"Eu criei meus filhos aqui, não que eu tô falando favela... Muita gente tem medo de favela. Eu mesmo tinha. Mas porque eu nunca tinha morado também. Eu achei que só tinha gente ruim dentro da favela. Meu cunhado me trouxe e eu num tinha outra opção também, não tinha condições de pagar aluguel. Eu vinha ou ficava na rua com meu filho. Mas cheguei, to vivendo na favela com medo, não porque tem gente ruim, tem gente boa também muita gente boa, mas tem gente que manda sabe?"

"E aí ta aí essa favela verticalizada. Pra você ter idéia, esse prédio, o esgoto dele fica um barraco em cima. Quando o esgoto dele entope, nós temos que ir lá e já levar o cimento pra moça deixar desentupir as coisas..."

0 fato da Prefeitura não ter concluído a obra é apontado como uma das principais causas da favelização do conjunto, pois a favela cresceu de novo e tudo continuou como estava.

"Quando nós trouxemos as últimas famílias, ainda ficaram na favela 68 famílias. Foi na época da mudança do Maluf pro Pitta, e o Maluf deu a obra por encerrada. Então o que aconteceu, o pessoal da favela que, era umas 68 famílias, acabou aumentando e hoje deve ter unas trezentas ou mais."

"Que nem, a melhoria daqui é se terminasse, o ruim o bom, tinha que terminar, tinha que ter um espaço pra essas crianças brincar, porque que nem elas fica presa aqui."

"Igual na favela, eles inventou fazer alguma coisa, mas se você passar lá, ce vai ver é um lixão."

Embora as pessoas tenham considerado uma melhora de vida da condição de moradia anterior, o Cingapura não é o lugar que elas escolheriam para morar, e muitas pretendem se mudar assim que tiverem condições.

"Eu quero um dia ter condições e espero que um dia eu tenha de sair daqui, né. Que nem esse meu filho que eu falei pra você, que nasceu aqui, já casou, mora na favela também. Porque ele não tem condição de pagar um aluguel e conviver com os filho dele. Ce vê, foi criado aqui e mora na favela também... Num é fala que a gente mora porque a gente quer, a gente mora porque é obrigado." 
"Eu não vejo nem um futuro aqui. Eu moro aqui, não pretendo morrer aqui. Acho que a gente precisa organizar as crianças. Se eu ainda vou fazer alguma coisa, é pelas crianças, e talvez eles cuidem daqui um dia, né. Porque a maioria dos pais que tão aí nem tão aí. A maioria do pessoal quando chega a uma certa idade já tá na mão do quarto poder, né."

\section{(3) Apropriação e Caracterização do Bairro.}

0 bairro é considerado bom pelo fácil acesso aos serviços como o Shopping, grandes supermercados, e até mesmo pela facilidade de ir para o litoral. Mas, como aponta uma moradora, qualquer tipo de diversão, mesmo que fisicamente próxima, tem acesso dificultado por ser tudo pago, impedindo que a maioria usufrua os serviços disponiveis. Opções de lazer alternativas, promovidas pelo poder público, não existem, sendo uma reivindicação dos moradores.

\footnotetext{
"É bom aqui, é perto do centro, a gente tá perto de ir pra Santos, ir pro Zoológico, dá pra ir a pé, o shopping aqui do lado, Carrefour, sacolão, tem tudo aqui perto, uma coisa é complicada, mas a gente vai levando. A única coisa que é difícil aqui, que nem hoje a gente conseguiu a quadra, mas o problema é cultura, a gente não tem quase nada aqui pra se divertir. Tem assim, o cinema é no shopping mas tem que pagá, né, o zoológico tem que pagá."
}

"No nosso bairro, o que falta é uma atividade de cultura e lazer, o que falta é uma atividade oficial, né, coisa do governo, do Estado, né, um centro de cultura, um local pra criançada aprender informática, o ideal aqui pro nosso bairro seria um CEU..."

A vizinhança com a Favela da Água Funda, onde o tráfico de drogas está instalado, interfere na vida das pessoas.

"Nós qué uma coisa e eles qué outra, então..."

Apesar de ser um bairro central, como dito, de fácil acesso a transportes e serviços, e que tem melhorado em relação aos anos anteriores, não é um local onde os atuais moradores pretendem criar raízes. Se assim o fazem, é por falta de opção.

"Mas tá melhorando muito, tem muita coisa errada, mas hoje as polícia vem, entra e
tudo. Que nem eu te falo, eu tô bem, mas não quero morrer aqui. Eu quero um dia ter
condições, e espero que um dia eu tenha, de sair daqui, né. Que nem, esse meu filho
que eu falei pra você que nasceu aqui, já casou, mora na favela também, porque ele
não tem condição de pagar um aluguel e conviver com os filho dele. Ce vê, foi criado
aqui e mora na favela também...num é fala que a gente mora porque a gente quer, a
gente mora porque é obrigado..."

\section{(4) Expectativas e Participação Social}

Quanto ao futuro o que as pessoas esperam "é um dia poder melhorar de vida e sair desse lugar." Não há no discurso esperança de melhorias no futuro para o conjunto, fato atribuído a desunião dos moradores. Mesmo quem tenta, acaba desanimando até mesmo por ameaças. Assim, a situação atual é considerada como transitória.

"Eu gostaria de pensar que isso daqui a uns anos vai ser maravilhoso, né, mas eu acho que isso aqui não vai mais existir. Mesmo porque a gente tá em cima do leito de uma avenida... E quem faz a moradia são os moradores, e a maioria não quer saber, só quer saber do seu umbigo. Não tem muito jeito, você arruma vem outro e quebra, você limpa outro vai e suja, você pinta outro vai e picha, então desanima. A gente tenta, conseguimos até $m$ professor de capoeira pra vir dar aula pra molecada de graça. Aí 
ele precisava de mais pessoas que viessem porque foi aumentando o grupo, aí veio um numa moto, a moto parou e correu uns três pra cima dele, aí lá foi eu correndo... Uma vez a gente conseguiu uma parceria com o pessoal de uma empresa pra dar aula de alfabetização de adulto, tive outro impasse com o pessoal do quarto poder porque eles não queriam, não queriam o pessoal estudando aí não porque tava atrapalhando 0 comércio deles..."

".A Márcia mesmo, ela já tentou muita coisa, mas uma pessoa só não resolve o problema de muitos. Ela já fez reunião sobre a limpeza, sobre tudo, mas... Esses dias ela falou pra mim que foi ameaçada, eles chegam em cima dela..."

Já houve tentativa de se formar uma associação em conjunto com os moradores da favela que foram frustradas pela desunião.

"O pessoal não é unido não. A gente cansou de fazer reunião, de tentar montar a associação. É assim, é extremamente difícil, tem vários anos que a gente montou uma associação, mas assim a gente nunca tiramos o CNPJ. Pelo menos aqui nesse espaço, hoje a gente discutiu uma outra entidade, que unisse o povo da favela com os prédios, porque eles se sentem sempre discriminados, eles xingam a gente, que a gente é nariz empinado, metido..."

Exceto por uma convivência facilitada pela proximidade, não existe uma união de interesses da favela com o conjunto, apesar de todos compartilharem a mesma origem, e estarem em convivência há mais de 12 anos.

"Então, assim a gente discutiu, conversou e então a gente fizemos uma mistura pra ver se a gente consegue caminhar. Mas a maioria das crianças que vem sujar, bagunçar não são os daqui, são os de lá. Eles furaram um buraco no nosso muro pra fazer passagem e tem prédio que usa a água da favela, que não paga água mais, pôs uma torneirinha que puxa água e acabou. Nesse local aqui é muito difícil, é meio complicado a questão da organização, a gente já até tentou só que sempre tem que ter um puxando..."

As responsabilidades, trazidas pelo acesso a um tipo de moradia que exige algum grau de organização coletiva para o bom desempenho dos itens coletivos, como limpeza do condomínio, organização das lixeiras e as contas de água, se acumulam na mão de poucas pessoas, fato que foi atribuído à forma como foi organizado desde o começo o conjunto.

"Tá difícil porque as crianças vão nascendo, vão crescendo e vai zuando mais ainda né. E não tem muitas pessoas que querem se envolver. Há 10 anos que a gente tá morando nesse prédio e são as mesmas pessoas que tomam conta da água, da luz, de cobrar os outros, pra concertar isso e aquilo. A gente não consegue achar quem queira receber uma conta de água. Eu to tentando e não consigo achar, ficou na mão minha e dela. Um dia eu e ela se rebelou e ficou por conta do meu marido. Isso já foi por conta da forma que foi feita as coisas, ce vê, uma parte queria, outra parte não queria..."

"A coisa mais pior pra nós é a questão da água, porque é um relógio só enche a caixa e todo mundo usa. Devia ter a divisão, cada um com seu relógio, hoje já é possível, porque quem tem 6,7 filhos claro que usa mais do que quem tem 2. Aí tem pessoas que não tá nem aí porque não vai cortar, então a maior revolta é a questão da água, foi feito tudo junto..."

Sem a equação devida das responsabilidades coletivas, os problemas são levados adiante através da participação fragmentada de alguns moradores ou através da interferência ocasional da Prefeitura. 
"Eu, como moradora antiga, eu tô cansando. Pra varrer a rua, não precisa a gente ficar atrás de ninguém, a gente sabe que tem que limpar. Aqui dentro do prédio, nós temos que limpar. Eu dou a mão à palmatória, ultimamente eu não tenho limpado, porque você limpa e vem o pessoal lá de baixo pra sujar."

"A limpeza, por exemplo, a prefeitura vem, faz limpeza, mas só deu as costas... Pra mim não é assim. A gente tem que considerar aonde a gente mora, e os moradores deveriam de ter união."

"Que nem a assistente social já veio e perguntou pra mim sobre o lixo, eu falo, outro fala, mas outros num quer, diz que não, que tem que ser do jeito que está aí. Nem a prefeitura querendo dá num vai, que nem, quando entra interessa um pouquinho, mas falar a verdade os políticos, não todos, tudo pra mim é corrupto...".

Mesmo em condições adversas, sem respaldo nem da população moradora do conjunto, nem da moradora da favela, a liderança do conjunto continua empenhada na mobilização da comunidade.

"O seguinte... poucos participa, a reunião vem três, quatro, não dá pra decidir nada, ninguém quer nada com nada, era pra gente ter tirado a documentação pra ficar tudo em dia mas infelizmente, é ruim uma pessoa que lutar pra caramba e faz algum benefício e sempre leva não pra gente. Aí a gente parou de dá força para os outro, aí não compensa. Ela mesmo [a liderança], pessoa boa a gente pergunta qualquer coisa ela vai e desenvolve mesmo, dá pra ser uma vereadora da região aqui. Mas muitos não acreditam nela, pra você ver como ela tem bastante união, fizemos a reunião aqui junto com o pessoal da favela, a turma querem ser mais que nós, e não tem nada a ver, ela foi buscar a gente lá dentro..."

\section{(5) Participação no Processo de Produção da Moradia}

A proposição de participação no processo de produção da moradia significou para os moradores do Cingapura Imigrantes uma possibilidade de resolver questões pontuais que hoje são problemáticas, como a água.

"Era bom, era bom principalmente na parte da água, antes deles fazer o conjunto, pegasse todos os morador e fizesse uma reunião, numa parte era bom... Cada um tem seu cavalete, vem só um cavalete para o prédio, ai tem um débito, tem um débito muito alto. Se não voltar o condomínio, vai nada pra frente não, vai chegar uma hora, é arriscado eles querer tomar conta dos apartamentos, falta de união, uns tem outros não tem, nós já fizemos reunião com a Sabesp, mas a Sabesp não tá nem aí, pedimos 36 meses, ela não aceitou, queria os 30 mas queria no nome de uma pessoa que mora aí, mas ninguém vai se responsabilizar por isso."

0 fato de não ter participado em nenhuma etapa do processo de produção de suas moradias não incomoda os moradores. A responsabilidade deste processo é tida como dever da prefeitura, que também é incluida na perspectiva de superação dos problemas, ao invés da busca por soluções coletivas.

"Eu acho que eles deviam ter começo, meio e fim. Ficou inacabado, a nossa rua não tinha asfalto, a favela encostou na parede do prédio, não teve um término. Na verdade, a gente nunca vai saber como seria de fato esse conjunto do jeito que ele foi pensado pra ficar totalmente pronto. Hoje eu acho impossivel eles tirarem essa favela daí. Seria uma outra luta e tal que muita gente não está disposta a fazer, faltavam 68 famílias tinha todas as condições de terminar, fazer um estacionamento..." 


\subsubsection{Método Quantitativo}

Através da análise qualitativa das entrevistas, ficou claro que havia uma dificuldade em avaliar os conjuntos apenas pelo aspecto da análise dos discursos dos diversos atores sociais envolvidos. Surgiu então a idéia de avaliar quantitativamente a qualidade de vida dos moradores, a partir de suas próprias percepções.

A expressão "qualidade de vida" foi empregada pela primeira vez pelo presidente dos Estados Unidos Lyndon Johnson, em 1964, ao declarar que "os objetivos não podem ser medidos através do balanço dos bancos. Eles só podem ser medidos através da qualidade de vida que proporcionam às pessoas" (BERLIM e FLECK, 2003). 0 interesse em conceitos como "padrão de vida" e "qualidade de vida" foi inicialmente partilhado por cientistas sociais, filósofos e políticos, porém utilizado quase que irrestritamente nas ciências médicas, para avaliação de tratamentos e doenças.

Atualmente, a preocupação com o conceito de "qualidade de vida" refere-se a um movimento amplo dentro das ciências humanas e biológicas no sentido de valorizar parâmetros mais abrangentes que simplesmente indicadores econômicos ou sociais (The WHOOOL Group, 1994). Nos últimos anos, foram desenvolvidos vários métodos qualitativos e quantitativos de avaliação da qualidade de vida. Entre os últimos, destacam-se os questionários auto-aplicáveis, em sua maioria desenvolvidos nos Estados Unidos.

A aplicação transcultural, através da tradução de qualquer instrumento de avaliação, é um tema controverso. Alguns autores criticam a possibilidade de que o conceito de qualidade de vida possa não ser ligado à cultura, enquanto outros têm considerado que existe um "universal cultural" de qualidade de vida, isto é, que independente de nação, cultura ou época, é importante que as pessoas se sintam bem psicologicamente, possuam boas condições físicas e sintam-se socialmente integradas e funcionalmente competentes (FLECK et al, 1999).

Nesse sentido, a Organização Mundial da Saúde - OMS buscou desenvolver um instrumento de avaliação internacional, através de um projeto multinacional. Desse, nasceu o questionário WHOQOL-100 [World Health Organization Quality of Life], composto por 100 questões, com abrangência em vários aspectos (chamados de domínios), da qualidade de vida humana.

$\mathrm{Na}$ presente pesquisa optou-se por utilizar a versão reduzida - WH00OL-bref. - que mostrou o mesmo poder de discernimento da versão longa (The WHOOOL Group, 1998), com a adaptação em português realizada pelo grupo brasileiro da OMS (FLECK et al, 2000). 
0 questionário constitui-se de 26 questões e abrange quatro domínios, a saber:

\section{1- Domínio Físico:}

Dor e desconforto

Energia e fadiga

Sono e repouso

Mobilidade

Atividades da vida cotidiana

Dependência de medicação ou de tratamentos

Capacidade de trabalho

\section{2- Psicológico}

Sentimentos positivos

Pensar, aprender, memória e concentração

Auto-estima

Imagem corporal e aparência

Sentimentos negativos

Espiritualidade / religião / crenças pessoais
3-Relações sociais

Relações pessoais

Suporte (apoio) social

Atividade sexual

\section{4- Ambiente}

Segurança física e proteção

Ambiente no lar

Recursos financeiros

Cuidados de saúde

Novas informações e habilidades

Recreação e lazer

Ambiente físico

Transporte

Em cada questão o respondedor deveria marcar em uma escala de 1 a 5 o grau de satisfação em relação à determinada pergunta. 0 questionário completo é apresentado no anexo 1 deste trabalho.

Para cálculo do tamanho da amostra, foi realizada a estimativa do número de moradores de cada conjunto e utilizou-se o programa Epiinfo, e fixou-se um erro de 10\% (intervalo de confiança de 90\%). Os resultados são apresentados na tabela a seguir:

Tabela 22 - Dimensionamento da Amostra

\begin{tabular}{lcc}
\hline & Mutirão Campanha Gaúcha & Cingapura Imigrantes \\
\hline Unidades & 128 & 160 \\
No Estimado de pessoas & 512 & 640 \\
Tamanho da Amostra (IC=90\%) & 16 & 16 \\
\hline
\end{tabular}

$\mathrm{Na}$ aplicação dos questionários tivemos uma amostragem efetiva de 15 questionários no mutirão e 14 no Cingapura, sendo desconsiderados 2 questionários no primeiro (rasuras e nomeação) e 3 questionários no segundo.(em branco)

Em relação à caracterização da amostra temos:

Tabela 23 - Caracterização da Amostra

\begin{tabular}{lcc}
\hline & Mutirão Campanha Gaúcha & Cingapura Imigrantes \\
\hline Questionários Aplicados & 17 & 17 \\
Questionários Válidos & 15 & 14 \\
Homens & 3 & 4 \\
Mulheres & 12 & 10 \\
Idade Média & 40,26 & 36,15 \\
\hline
\end{tabular}

Foi notada grande dificuldade de algumas pessoas em responder o questionário, principalmente em relação ao entendimento do texto e à reduzida capacidade de leitura, em especial no Cingapura Imigrantes. 
Em relação a isso, pode-se observar que vários outros autores tiveram as mesmas dificuldades, principalmente ao aplicar o questionário em populações de menor nível educacional, apesar das adequações feitas à tradução brasileira (FLECK et al, 2000).

Após a tabulação dos dados, foi utilizado o programa Statistical Package for the Social Sciences - SPSS, para análise dos resultados, confecção dos gráficos e somatória dos domínios (pontuação), através de sintaxe própria desenvolvida pela OMS.'

\subsubsection{Apresentação de Resultados da Abordagem Quantitativa}

0 questionário foi aplicado de forma independente nos dois conjuntos analisados. A seguir, são apresentados os gráficos relativos às questões consideradas de relevância a presente pesquisa. No capítulo 4 serão apresentados os resultados agrupados por domínios e a discussão conjunta com os resultados da pesquisa qualitativa.

\subsubsection{Apresentação comparativa dos resultados}

A primeira questão dos questionários é de âmbito geral, não computável no cálculo da pontuação dos domínios:

Questão 1: Como você avaliaria sua qualidade de vida? Mutirão Campanha Gaúcha
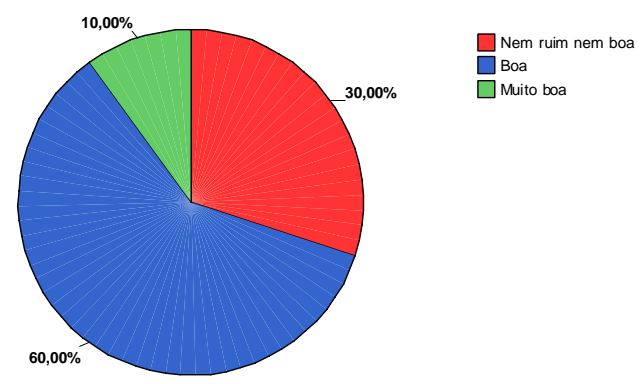

Questão 1: Como você avaliaria sua qualidade de vida? Cingapura

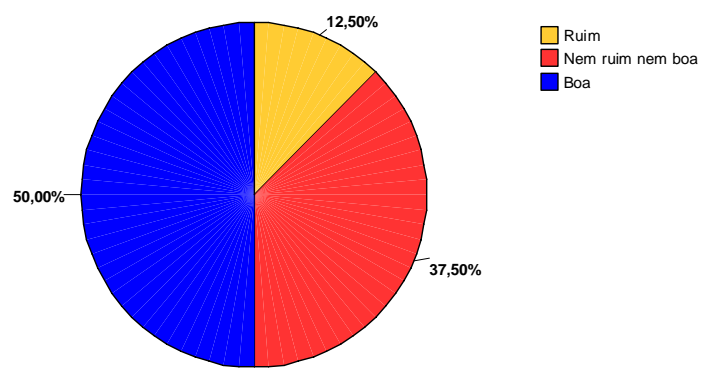

Figura 44 - Gráfico Questão 1 - FUNAPS

Figura 45 - Gráfico Questão 1 - Cingapura

Essa questão mostra uma primeira diferença marcante entre os dois grupos. Enquanto no Mutirão Campanha Gaúcha temos uma avaliação da qualidade de vida com 70\% das pessoas considerando-a como Boa ou Muito boa e 30\% com opinião indiferente, vemos no Cingapura Imigrantes $12,5 \%$ de avaliações como Ruim e nenhuma avaliação como Muito boa.

\footnotetext{
${ }^{1}$ Disponivel em: http://www.ufrgs.br/psiq/whoqol86.html
} 
Questão 2: Quão satisfe ito você está com a sua saúde? Mutirão Campanha Gaúcha

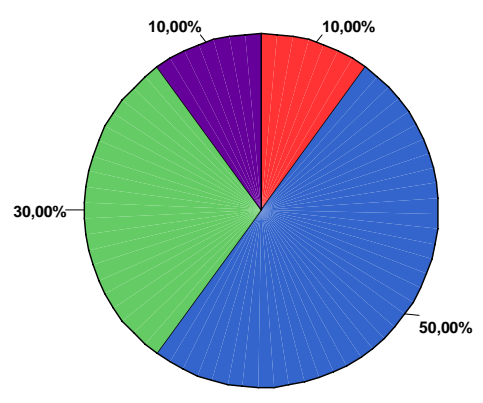

Questão 2: Quão satisfe ito você está com a sua saúde? Cingapura

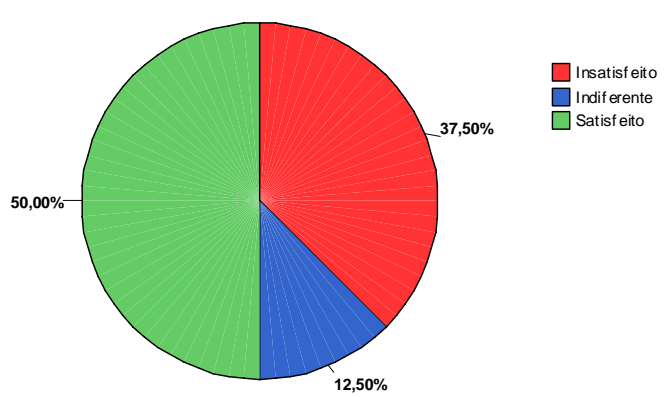

Figura 46 - Gráfico Questão 2 - FUNAPS

Figura 47 - Gráfico Questão 2 - Cingapura

A segunda questão também é de âmbito geral, e diz respeito sobre a percepção global da pessoa em relação à sua saúde.

Chama atenção a grande proporção de insatisfeitos com a saúde no Cingapura Imigrantes, assim como a ausência de Muito satisfeito. (presente no Mutirão)
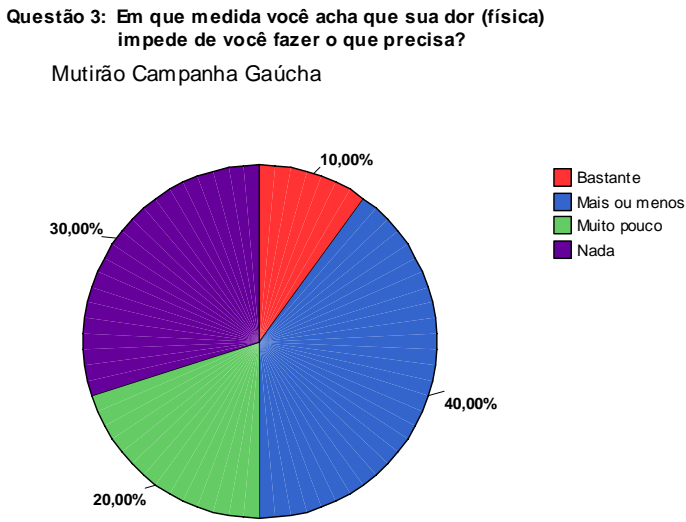

Figura 48 - Gráfico Questão 3 - FUNAPS

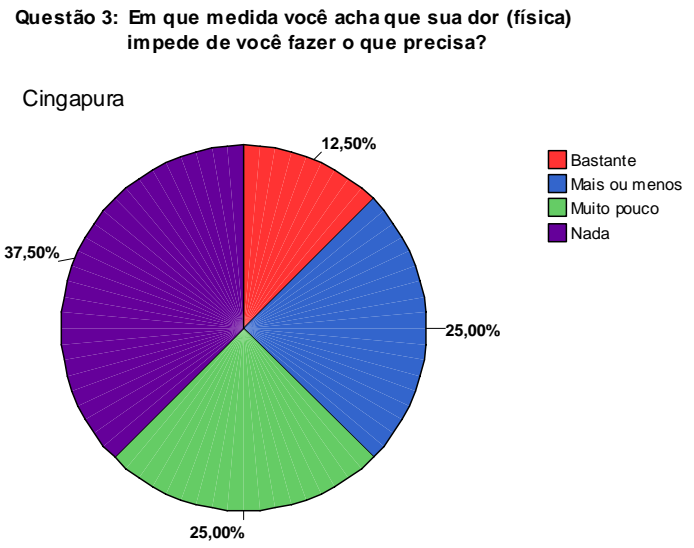

Figura 49 - Gráfico Questão 3 - Cingapura

A terceira questão não apresenta diferenças marcantes entre os dois conjuntos. Considerando a natureza da mesma (avaliação da limitação à vida diária causada pela dor física), pode-se considerar como uma questão discriminatória entre doentes fisicamente e não doentes. 0 resultado mostra uma homogeneidade da amostra em relação à saúde física.

A próxima questão considerada foi a número 5. Essa representa a percepção da pessoa em relação a aproveitar a vida, de forma não específica. Os resultados no Cingapura Imigrantes são mais variados. 
Questão 5: O quanto você aproveita a vida?

Mutirão Campanha Gaúcha

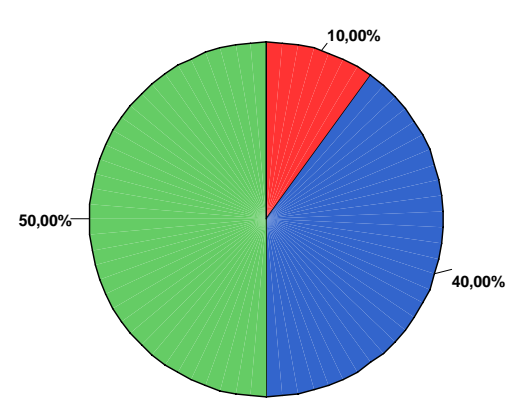

Figura 50 - Gráfico Questão 5 - FUNAPS

Questão 6: Em que medida você acha que a sua vida tem sentidc Mutirão Campanha Gaúcha

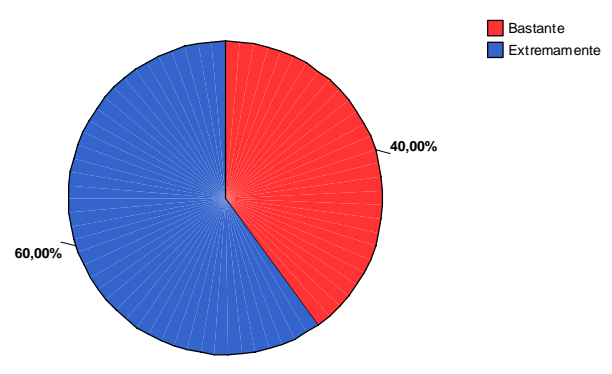

Figura 52 - Gráfico Questão 6 - FUNAPS
Questão 5: O quanto você aproveita a vida? Cingapura

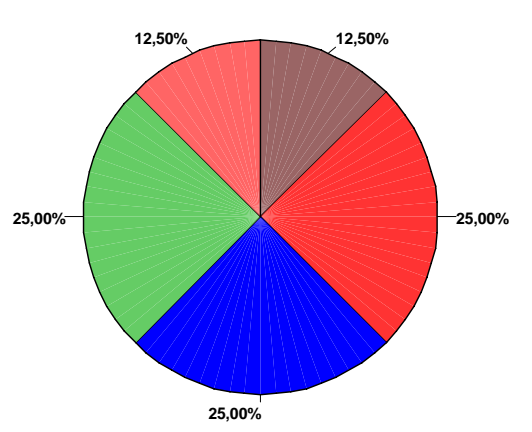

$\square$ Nada

$\square$ Muito pouco Mais ou menos Extremamente
Figura 51 - Gráfico Questão 5 - Cingapura

Questão 6: Em que medida você acha que a sua vida tem sentidc Cingapura

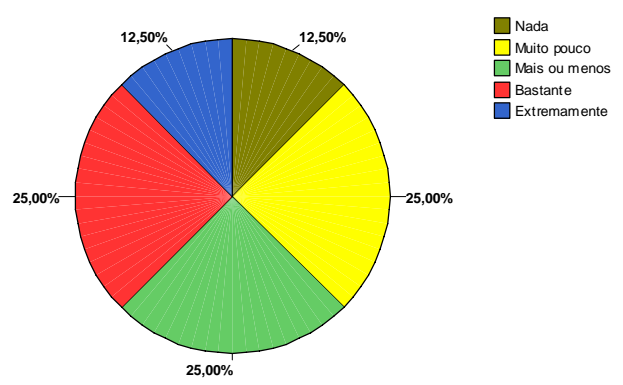

Figura 53 - Gráfico Questão 6 - Cingapura

A sexta questão apresenta resultados distintos nos dois conjuntos. No mutirão 100\% das pessoas avaliaram como sua vida tendo bastante sentido ou extremamente. Já no Cingapura, temos o impressionante número de 37,5\% de avaliações como nada ou pouco e $25 \%$ de indiferentes.

Questão 9: Quão saudável é o se u ambiente físico? Mutirão Campanha Gaúcha

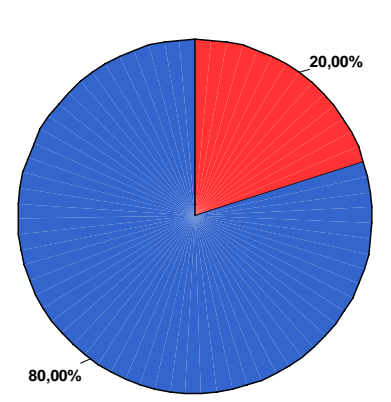

Figura 54 - Gráfico Questão 9 - FUNAPS
Questão 9: Quão saudável é o se u ambiente físico? Cingapura

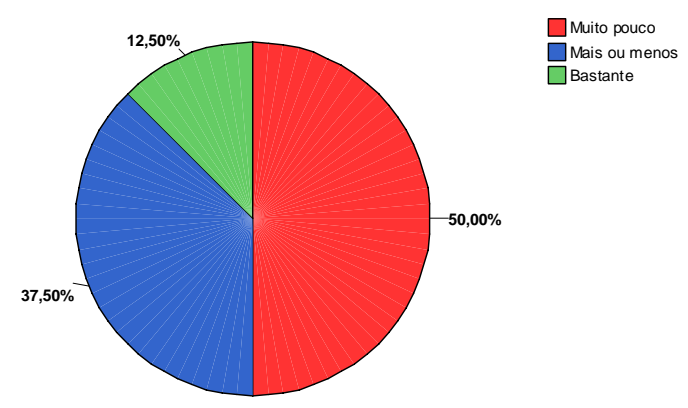

Figura 55 - Gráfico Questão 9 - Cingapura 
Essa questão avalia a percepção em relação ao ambiente físico, incluindo o clima, o barulho e os atrativos físicos do local de moradia. No Mutirão Campanha Gaúcha, notamos que todas avaliações se situam entre o mais ou menos ou o muito pouco. No Cingapura Imigrantes, há uma proporção maior de muito pouco, porém aparece a avaliação bastante.

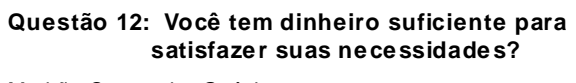

Mutirão Campanha Gaúcha

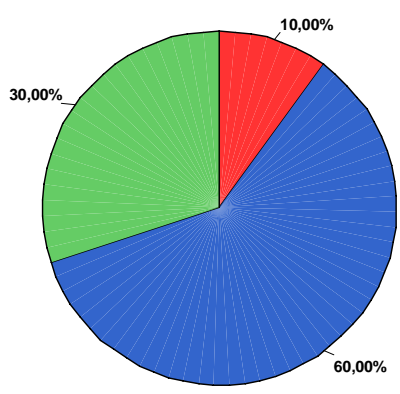

Figura 56 - Gráfico Questão 12 - FUNAPS
Questão 12: Você tem dinheiro suficiente para
satisfazer suas necessidades?

Cingapura

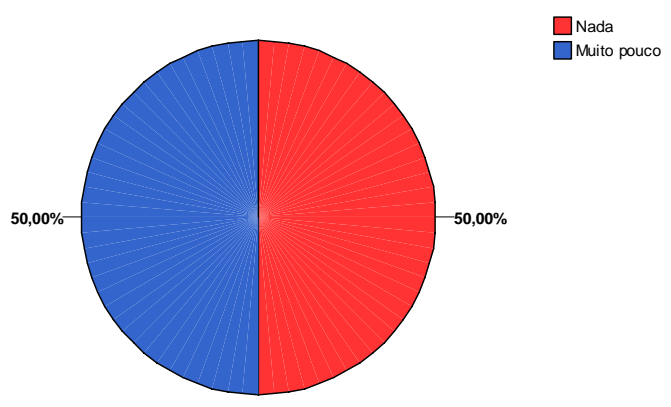

Avalia-se aqui a percepção acerca da disponibilidade de dinheiro para satisfação das necessidades subjetivas de cada um. No Cingapura Imigrantes, 50\% das pessoas avaliam como nada, ou seja, nenhum dinheiro para suas necessidades e outros 50\% como muito pouco. No Mutirão Campanha Gaúcha a proporção de nada é de 10\% e 30\% tem algum dinheiro (médio) para suas necessidades.
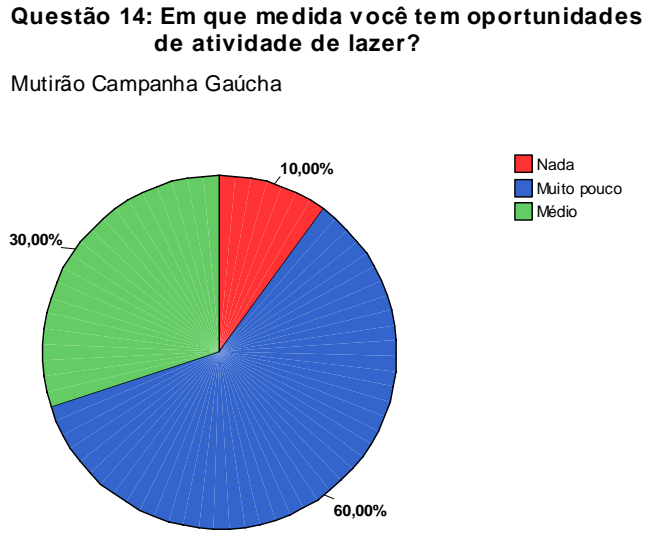

Figura 58 - Gráfico Questão 14 FUNAPS
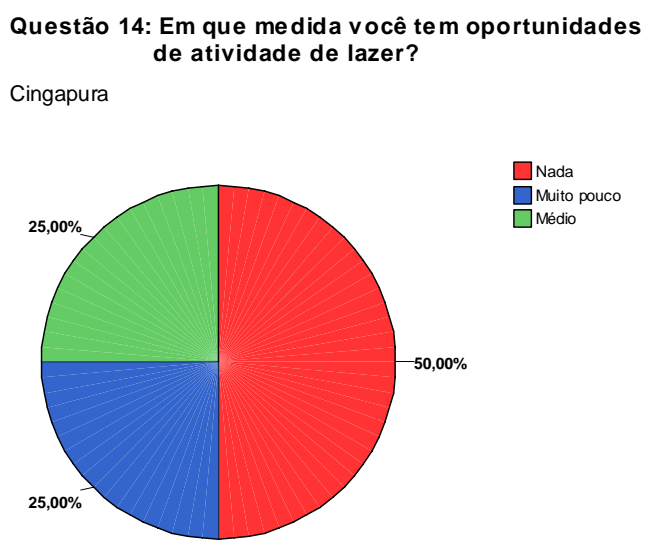

Figura 59 - Gráfico Questão 14 Cingapura

Em relação à percepção das atividades de lazer, 50\% dos moradores do Cingapura referem como nada e 25\% como muito pouco. No Mutirão Campanha Gaúcha, 10\% como nada e $60 \%$ como muito pouco. 


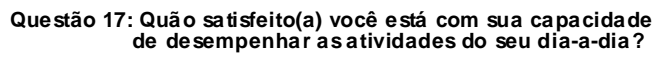

Mutirão Campanha Gaúcha

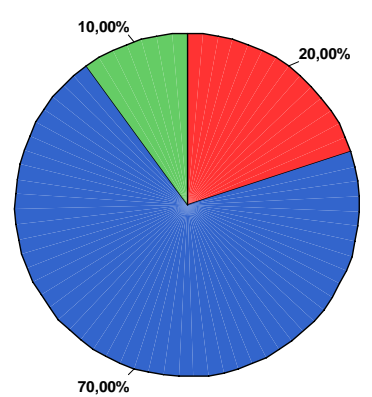

Figura 60 - Gráfico Questão 17 FUNAPS
Questão 17: Quão satisfeito(a) você está com sua capacidade de desempenhar as atividades do seu dia-a-dia? Cingapura
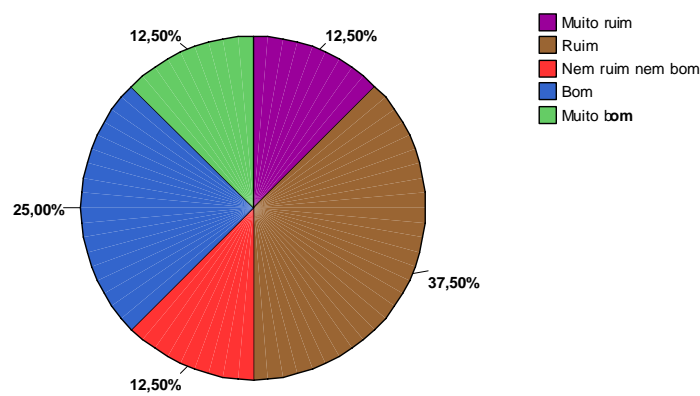

Figura 61 - Gráfico Questão 17 Cingapura

A questão 17 refere-se a satisfação pessoal com a capacidade de desempenhar as funções cotidianas. Aqui, um impressionante valor de 50\% de ruim ou muito ruim no Cingapura Imigrantes e nenhum ruim ou muito ruim no Mutirão Campanha Gaúcha.

Questão 19: Quão satisfe ito(a) você e stá consigo me smo? Mutirão Campanha Gaúcha

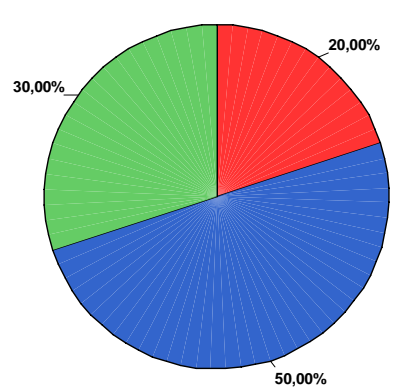

Questão 19: Quão satisfe ito(a) você está consigo me smo? Cingapura

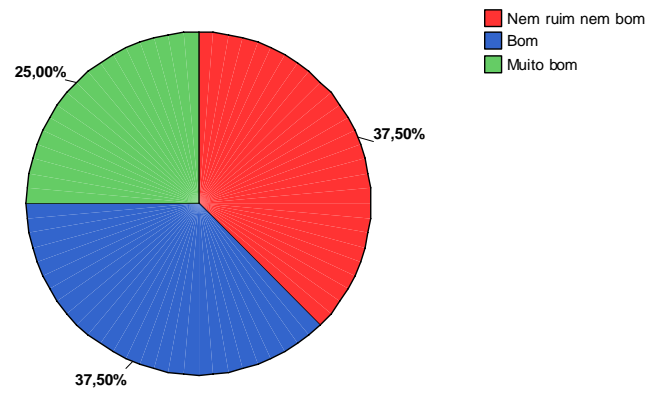

Figura 62 - Gráfico Questão 19 FUNAPS

Figura 63 - Gráfico Questão 19 Cingapura

Nesse quesito, não observamos diferenças significativas entre os dois conjuntos.

Que stão 20: Quão satisfe ito(a) você está com suas relaçõe s pessoais? Mutirão Campanha Gaúcha

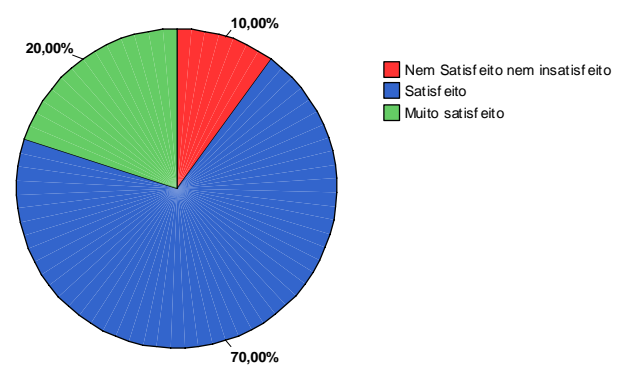

Figura 64 - Gráfico Questão 20 FUNAPS
Que stão 20: Quão satisfe ito(a) você está com suas relaçõe s pessoais? Mutirão Campanha Gaúcha

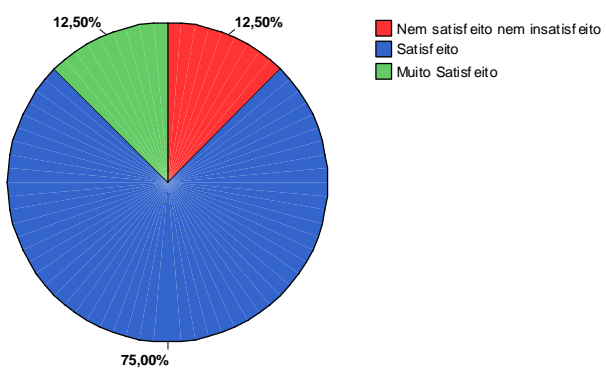

Figura 65 - Gráfico Questão 20 Cingapura 
Questão 22: Quão satisfe ito(a) você e stá com o apoio que você rece be de seus amigos? Mutirão Campanha Gaúcha

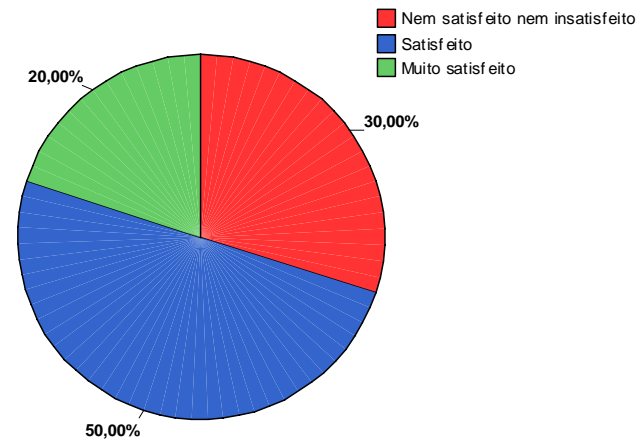

Figura 66- Gráfico Questão 22 FUNAPS
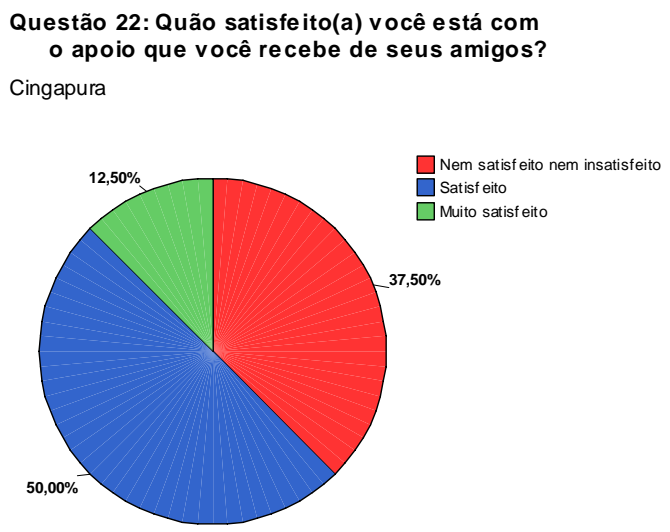

Figura 67 - Gráfico Questão 22 Cingapura

Essas duas questões referem-se à satisfação social dos moradores e não apresentam diferenças entre os dois conjuntos.

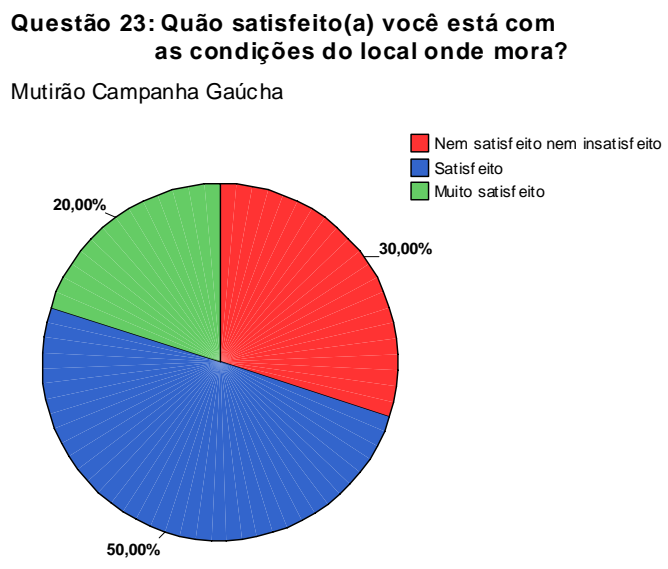

Figura 68 - Gráfico Questão 23 FUNAPS

\begin{abstract}
Questão 23: Quão satisfe ito(a) você e stá com as condições do local onde mora?
\end{abstract} Cingapura

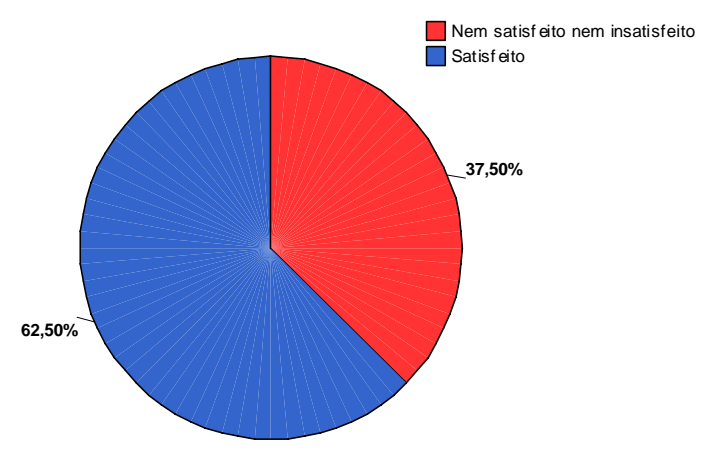

Figura 69 - Gráfico Questão 23 Cingapura

Os resultados mostram 62,5\% de satisfeitos e $37,5 \%$ de indiferentes no Cingapura Imigrantes, enquanto que no Mutirão Campanha Gaúcha 50\% de satisfeitos e 20\% de muito satisfeitos. 
Questão 24: Quão satisfeito(a) você está com o se u ace sso aos serviços de saúde?

Mutirão Campanha Gaúcha

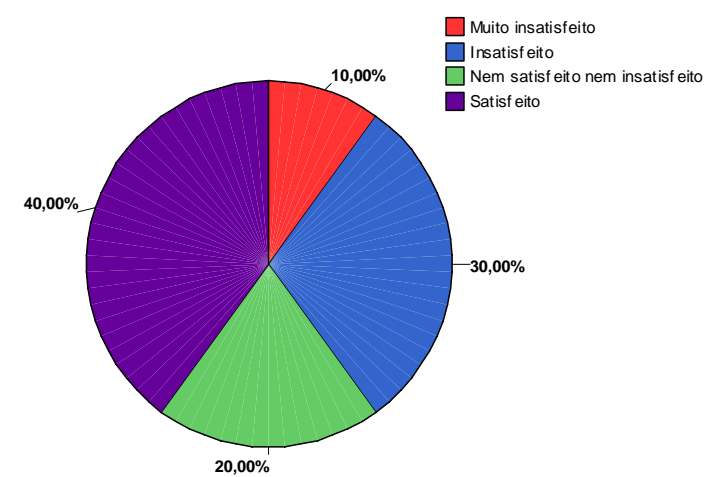

Figura 70 - Gráfico Questão 24 FUNAPS Questão 24: Quão satisfe ito(a) você e stá com o
seu ace sso aos serviços de saúde?

Cingapura

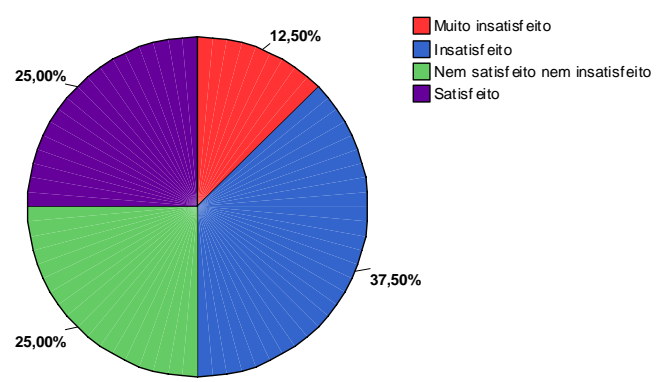

Nos mostra a satisfação em relação ao acesso ao sistema de saúde, apresentando proporções semelhantes nos dois conjuntos.

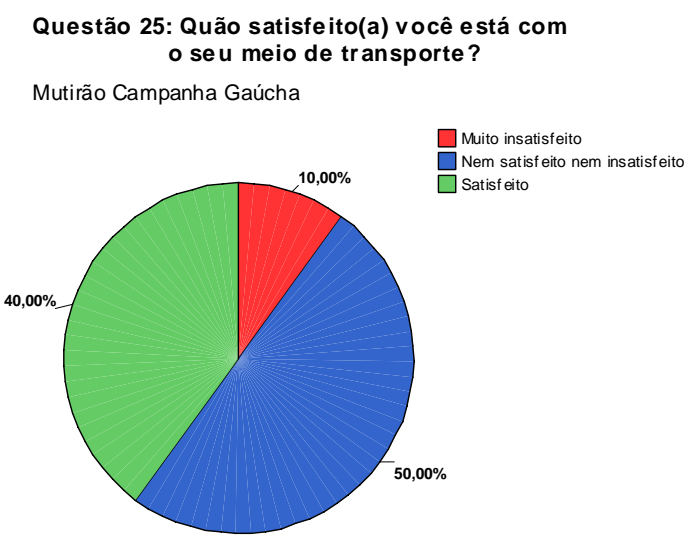

Figura 72 - Gráfico Questão 25 FUNAPS

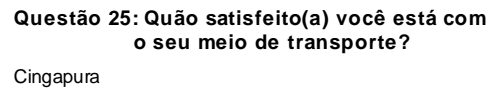
o seu meio de transporte? Cingapura

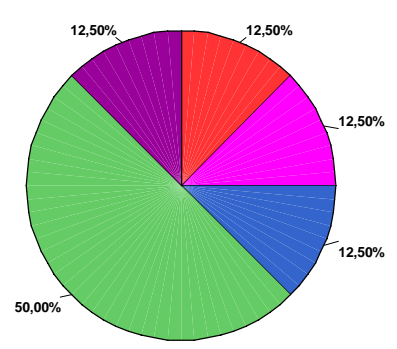
Nem satisf eito nem insatisf eito Satisfeito Mito satisfeito

Figura 73 - Gráfico Questão 25 Cingapura

Apresenta maior satisfação no Cingapura Imigrantes, com 62,5\% de satisfeitos ou muito satisfeitos.

Questão 26: Com que freqüência você tem sentimentos negativos tais como mau humor, de sespero, ansiedade, de pressão?

Mutirão Campanha Gaúcha

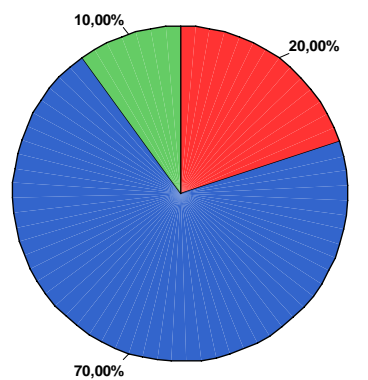

Figura 74 - Gráfico Questão 26 FUNAPS
Que stão 26: Com que freqüência você tem sentimentos negativos
tais como mau humor, dese spero, ansie dade, depressão?

Cingapura

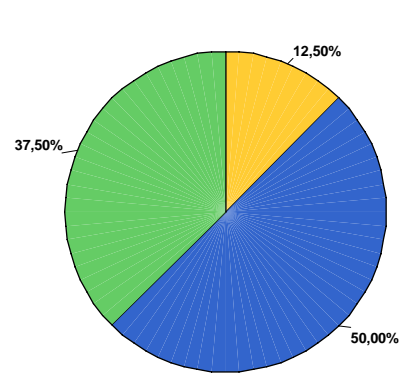

$\square$ Frequentemente $\square$ Nunca

Figura 75 - Gráfico Questão 26 Cingapura 
Trata-se da última questão e trata de sentimentos negativos, como depressão, ansiedade,etc. Os resultados do Cingapura Imigrantes são de menor proporção desses problemas em relação ao Mutirão Campanha Gaúcha.

Além da descrição das questões e suas proporções, foi efetuado o cálculo da pontuação geral do questionário, através da rotina proposta pela OMS.(vide sintaxe no anexo 2 deste trabalho).

Cada domínio foi calculado como uma média ponderal de questões e transformação dos escores em escala de 100. 0 domínio físico foi composto pelas questões 3,4,10,15,16,17 e 18 . 0 domínio psicológico pelas questões 5,6,7,11,19 e 26. 0 domínio social pela questões 20, 21 e 22, e o domínio ambiental pela questões $8,9,12,13,14,23,24$ e 25 . Por fim o domínio geral foi calculado com as questões 1 e 2 .

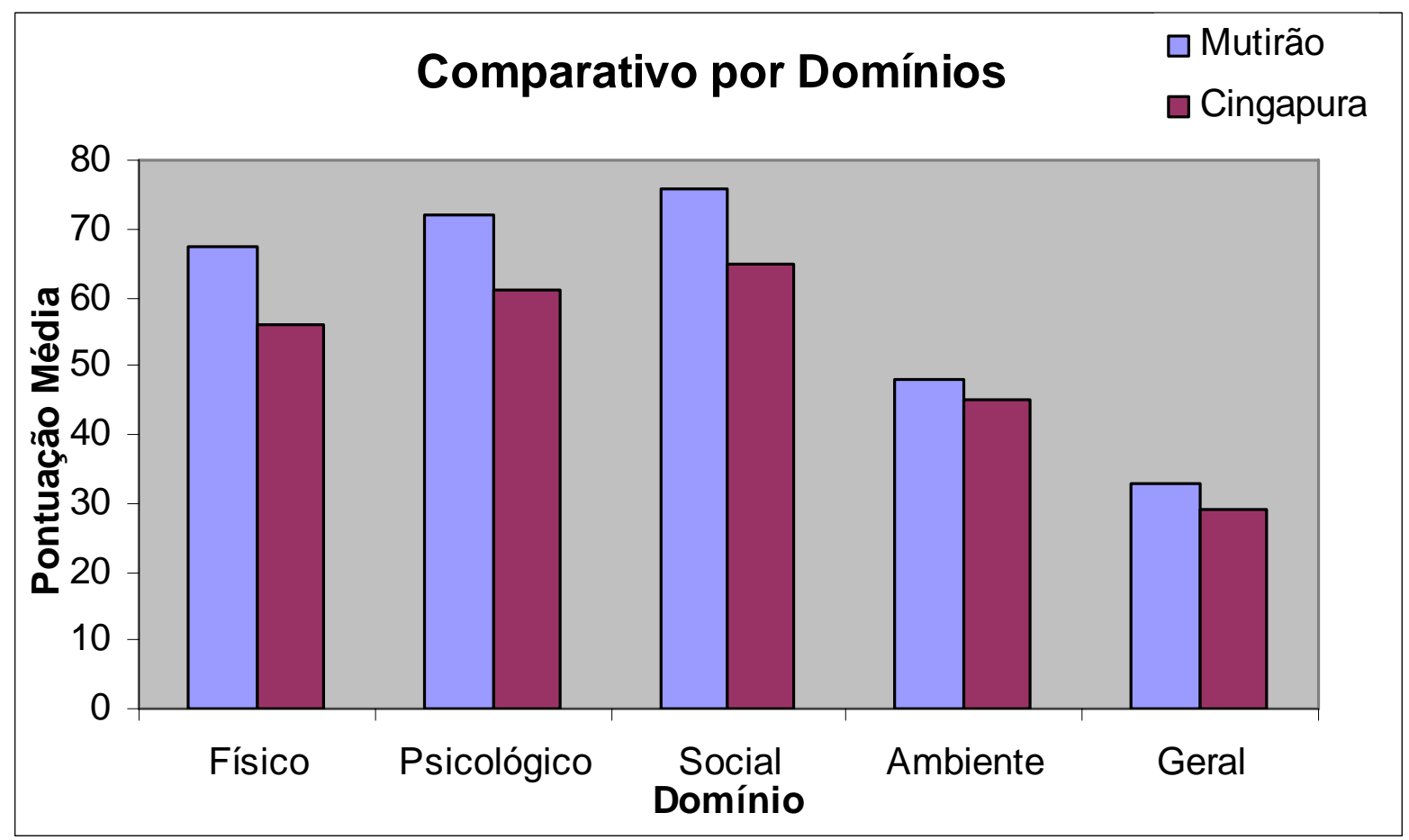

Figura 76 - Gráfico Comparativo por Domínios 


\section{capítulo 4}

\section{Discussão dos resultados}

Nesse capítulo são discutidos comparativamente os resultados obtidos na pesquisa qualitativa e quantitativa dos empreendimentos estudados, a luz do contexto histórico apontado no primeiro capítulo deste trabalho e da bibliografia consultada pertinente ao assunto. Também foi considerado nessa discussão o conjunto de aspectos observados durante as inúmeras visitas aos empreendimentos, que por vezes não estão contemplados nem nos depoimentos, nem no questionário aplicado.

Essa discussão subsidia algumas conclusões a respeito da forma como os meios utilizados nos processos de acesso à moradia, através dos programas públicos de habitação estudados, influenciaram na vida de seus moradores nos mais diversos aspectos: sócio-culturais, políticos, econômicos e até mesmo físicos. Sendo esta a principal contribuição que este trabalho procurou trazer.

\subsection{Discussão comparativa dos resultados da pesquisa qualitativa.}

Assim como foi feito para a análise das entrevistas, a discussão dos resultados obtidos nos dois casos estudados também será balizada pelos 5 tópicos definidos de interesse específico dessa pesquisa, quais sejam:

1. Quanto à trajetória habitacional;

2. Quanto à apropriação e caracterização da moradia;

3. Quanto à apropriação e caracterização do bairro;

4. Quanto às expectativas, iniciativas e participação social;

5. Quanto à participação no processo de produção da moradia.

\subsubsection{Quanto à trajetória habitacional.}

Os dois grupos estudados tiveram trajetórias muito distintas até chegar à situação atual de moradia.

No caso do Campanha Gaúcha, os moradores são originários, em sua maioria, de casas alugadas, estas localizadas no próprio bairro (Guaianazes), ou nas imediações. Esse fato deve ser entendido dentro do modelo de crescimento adotado pela cidade de São Paulo, exposto no primeiro capítulo deste trabalho, baseado no loteamento periférico, na maior parte das vezes clandestino e na autoconstrução, que levou enorme contingentes populacionais a ocupar as áreas mais periféricas da cidade, das quais o bairro de Guaianazes faz parte. 
Se forem analisadas as condições de moradia desses bairros na década de 80 , como também foi exposto no primeiro capítulo deste trabalho, verifica-se que, pela precariedade de acesso a serviços básicos de infra-estrutura e transporte, a casa alugada, nesse caso, não diferiria qualitativamente de um barraco na favela.

Os moradores do Campanha Gaúcha descreveram que a motivação inicial do mutirão foi a obtenção da casa própria, entendendo que a condição de aluguel é tida sempre como transitória e precária. Então, independentemente das reais condições da moradia anterior, se a casa era pequena, se não tinha esgoto ou transporte, o que mais incomodava era a insegurança atribuída à casa alugada.

No caso do Cingapura Imigrantes, a trajetória de moradia até chegar à situação atual foi distinta do caso apresentado anteriormente. Assim como preconizavam as diretrizes do PROVER, citadas no segundo capítulo deste trabalho, a população alvo deste programa foi a moradora em favelas, sendo essa a situação habitacional anterior da população do Cingapura Imigrantes, originários da Favela Água Funda.

Já as diretrizes do FUNAPS Comunitário, priorizaram o atendimento à população de baixa renda organizada. Nota-se, já nesse ponto, uma diferença de postura essencial para a análise dos resultados obtidos nos dois programas estudados.

Pode-se considerar que tanto o barraco na favela, quanto a casa de aluguel na periferia de São Paulo, na década de 80, desempenham o mesmo o papel na vida de seus moradores: constituem-se estratégias de sobrevivência em tempos de crise.

Portanto, embora se tratasse, de maneira geral, do mesmo público alvo - se for considerado, por exemplo, o fator renda, ou a condição inicial de moradia - a condição imposta pelo FUNAPS Comunitário, de se trabalhar com a população organizada, impõe uma diferença fundamental entre os dois grupos: o amadurecimento em práticas coletivas trazido em grande parte pela participação institucionalizada nos Movimentos de Moradia ${ }^{1}$, ao passo que a população trabalhada pelo Cingapura Imigrantes não possuía nenhuma organização nesse sentido.

No entanto, deve-se considerar o fato de que existia, na comunidade favelada, segundo os depoimentos, uma rede relações sociais estabelecida - como pode ser observado no caso descrito de aquisição de um barraco - o que pode ser entendido como um terreno fértil para o desenvolvimento de organizações coletivas que visam alcançar algum objetivo em comum.

Nesse ponto, pode-se destacar como conseqüência da já mencionada diretriz de acesso ao financiamento do FUNAPS Comunitário, o incentivo à formação de associações comunitárias, como foi o caso do próprio Campanha Gaúcha.

\footnotetext{
${ }^{1}$ Sobre os Movimentos de Moradia e sua importância no desenvolvimento dos mutirões autogestionários, ver: GOHN, 1991.
} 
No caso do Cingapura, a teia de organização - ou o autocontrole que existia na favela foi substituída por uma outra, com regras de organização muito diferentes: um síndico por bloco, que teria que receber o condomínio e fazer o intermédio com a prefeitura. Esse modelo mostrou-se inadequado no Cingapura Imigrantes. Como foi descrito pelos moradores, ninguém quer se comprometer e tomar para si as responsabilidades que são coletivas em uma comunidade tão desunida.

É no que se refere especificamente a trajetória que vai da situação anterior de moradia até a atual, que as conseqüências das diferentes posturas entre os dois programas são evidenciadas. Os depoimentos transcritos no terceiro capítulo desse trabalho corroboram essa afirmação. Deve-se considerar também a duração do processo em questão. No caso do Campanha Gaúcha foram cinco anos, sendo que no Cingapura Imigrantes, da desocupação dos barracos até a inauguração dos prédios foi apenas um ano.

Nos depoimentos dos moradores do Campanha Gaúcha, o processo de acesso à moradia, através do mutirão autogerido, é descrito com propriedade e riqueza de detalhes. Percebe-se que, mesmo tendo doze anos após o final das obras, a forma como foi construído o conjunto foi profundamente marcante na vida daquelas pessoas, quer pelo esforço físico pronunciado, quer pelo novo ciclo de relações sociais estabelecido.

No Cingapura Imigrantes, o processo de viabilização do programa ficou marcado na visão dos moradores como uma atitude assistencialista da prefeitura, de forma que o fato de não ter participado de nenhuma etapa do processo, apesar de reconhecido, é tido como natural, pois a responsabilidade pelo sucesso do programa foi completamente atribuída à prefeitura.

No caso do Campanha Gaúcha, na medida em que a maior parte da responsabilidade pelo gerenciamento, coordenação e execução do processo ficou a cargo dos moradores e não da prefeitura, esta última, na figura de seu corpo técnico, foi entendida como uma parceira da associação no desenvolvimento dos trabalhos,

Se comparados os dois processos, nota-se que as diferentes posturas de trabalho com a população, determinadas nas diretrizes de cada programa, produziram conseqüências marcantes para cada processo de produção e, mais tarde, para a ocupação e apropriação desses conjuntos.

\subsubsection{Quanto à apropriação e caracterização da moradia}

Em mais de dez anos de ocupação, o vínculo que o morador desenvolveu com sua casa ou apartamento também é bastante distinto para os dois casos estudados.

No caso do Cingapura Imigrantes, o apartamento resultou para os moradores em melhores condições de vida, se comparado com a moradia anterior. Porém, essa mudança não foi uma mudança estrutural na vida daquelas pessoas. 0 fato dos moradores ainda se considerarem favelados confirma tal afirmação. 0 apartamento, assim como o barraco na 
favela, também é considerado como transitório: "nasci aqui, mas um dia quero ter condições de sair, se Deus quiser...".

Isso poderia explicar o fato de quase não existir melhorias realizadas pelos moradores no conjunto e de que, em apenas dois anos após ser reformado, este esteja em condições tão precárias. Essa precariedade notória dos escassos espaços públicos, por outro lado, prejudica o convívio coletivo que já é preterido em relação à convivência privada, fazendo com que o apartamento tenha mais importância do que os espaços coletivos no desenvolvimento das relações sociais.

Já no caso do Campanha Gaúcha, a convivência coletiva, nutrida durante os cinco anos de contato pelo processo de mutirão, fez com que os espaços de uso comum, como o centro comunitário, as praças, a quadra e as ruas fossem intensamente utilizados.

Com relação às casas do Campanha Gaúcha, a grande maioria passou por algum tipo de intervenção por parte dos moradores, o que pode ser entendido como parte de um processo de apropriação das mesmas.

0 tamanho das casas no caso do Campanha Gaúcha, como dos apartamentos no caso do Cingapura Imigrantes foi considerado satisfatório na opinião dos entrevistados.

Analisando a situação jurídica dos dois conjuntos, verifica-se em ambos que ainda existem problemas com os contratos entre os moradores e a prefeitura.

No Cingapura Imigrantes, existe um contrato de título de posse que os moradores originais receberam o Título de Permissão de Uso Precário e Oneroso - TPU, que significa que os moradores têm a propriedade, mas não a posse. A posse definitiva, embora prometida, não tem previsão de se efetuar, pois o terreno no qual foi construido o Cingapura Imigrantes não está regularizado, situação que impede qualquer tipo de negociação com a área. Assim, os repasses de apartamentos, que segundo os depoimentos é muito freqüente, são feitos na ilegalidade, na forma dos "contratos de gaveta". Um apartamento do Cingapura Imigrantes pode variar de $\mathrm{R} \$ 2$ mil a $\mathrm{R} \$ 10$ mil.

A forma precária como acontece a negociação dos apartamentos e mesmo o baixo valor praticado nessas negociações podem ser entendidos como conseqüência da inadequação do programa às expectativas dos usuários.

No caso do Campanha Gaúcha, a situação dos contratos com a prefeitura também ainda não está regularizada, pelo mesmo motivo que no Cingapura Imigrantes: a situação irregular do terreno. Esse fato tem provocado grande desgaste nos moradores que, depois de cinco anos de trabalho árduo construindo suas casas, não têm nenhuma garantia formal de posse das mesmas.

Assim, observa-se que a condição legal do terreno acabar por influir diretamente no modo como os moradores vão se apropriar das unidades habitacionais e do próprio conjunto. A 
falta de contratos que contemplem as expectativas dos moradores, que em ambos os casos é a posse definitiva das casas ou apartamentos, trouxe sérias conseqüências notadamente para 0 modo como os moradores se apropriam dos conjuntos.

A substituição dos moradores originais apresenta caracteristicas diferenciadas para os dois conjuntos.

No Cingapura Imigrantes, os depoimentos relataram uma alta rotatividade de moradores. 0 motivo apontado para esse fato é geralmente o retorno à cidade de origem ou até mesmo à condição de morador de favela. Nota-se, nesse caso, que não há uma ligação duradoura com o lugar de moradia, essencial para o desenvolvimento das relações sociais, conforme foi discutido no primeiro capitulo deste trabalho.

Por outro lado, pode se dizer que o acesso a uma unidade habitacional do programa não alavancou o desenvolvimento, nem econômico, nem social, da familia, visto que muitos, ou retornaram para a sua condição de origem, ou ainda continuam na mesma situação social de quando eram moradores da favela.

Em contrapartida, no caso do Campanha Gaúcha, a rotatividade de moradores é baixa na percepção dos entrevistados. Todos os moradores são pessoas conhecidas e, geralmente, o direito à propriedade das casas é repassado de pai para filho ou entre outros parentes.

Algumas casas também foram negociadas através de "contratos de gaveta", o valor dessa negociação pode chegar a $\mathrm{R} \$ 30.000,00$. Como foram poucos os casos, cerca de 20 casas, os moradores não souberam precisar esse valor.

Uma rápida comparação do preço negociado nos dois casos estudados, permite verificar uma supervalorização das casas de $60 \mathrm{~m}^{2}$ localizadas a mais de $20 \mathrm{Km}$ do centro da cidade em relação aos apartamentos de $41 \mathrm{~m}^{2}$ localizados a apenas $7,5 \mathrm{Km}$ do centro da cidade e a menos de mil metros da linha verde do metrô.

\subsubsection{Quanto à apropriação e caracterização do bairro}

Nos dois casos estudados foram notadas grandes diferenças na forma de interação do bairro com o conjunto.

0 Cingapura Imigrantes é hoje parte integrante da favela Água Funda. 0 propósito da intervenção pública através do PROVER, de transformar a favela em um bairro, não foi bem sucedido, na percepção dos moradores: "isso aqui é uma favela em pé".

Se por um lado, a favela não conseguiu se integrar ao bairro Jardim da Saúde, por outro, este bairro tem se valorizado no mercado imobiliário. A cerca de 300 metros do Cingapura Imigrantes, há vários lançamentos imobiliários, com apartamentos de alto padrão. 
Mesmo morando em um bairro bem localizado dentro da cidade de São Paulo, os moradores do Cingapura Imigrantes não têm como perspectiva desenvolver raízes naquele lugar. Se assim o fazem, é por falta de oportunidades que propiciem a saída.

Este fato deve ser analisado dentro do modelo histórico de desenvolvimento urbano da cidade. A lógica de expulsão da população de baixa-renda dos locais providos de infra-estrutura não conseguiu ser superada pela intervenção do poder público nesse sentido, no caso do Cingapura Imigrantes.

Assim, ao invés de lutarem pelo direito de permanência no local, muitos moradores acreditam que no futuro o conjunto pode até ser destruido: "Eu gostaria de pensar que isso daqui a uns anos vai ser maravilhoso, mas eu acho que isso aqui não vai mais existir, mesmo porque a gente tá em cima do leito de uma avenida...".

No caso do Campanha Gaúcha, a situação do conjunto em relação ao bairro é bem diferente. Como se observa analisando a foto aérea do bairro, o conjunto mantém o mesmo padrão do entorno. A convivência rotineira dos vizinhos de bairro dentro do conjunto, onde utilizam a quadra, as praças e participam do Programa Leve-Leite, coordenado pelo Campanha Gaúcha, também pode ser lida como um sinal dessa integração.

Os problemas sentidos pelos moradores do conjunto são os mesmos que os moradores da vizinhança também enfrentam. Guainazes é um bairro quisto pelos moradores do Campanha Gaúcha. Lá eles desenvolveram raízes, não por falta de opção, mas ao contrário, por considerarem o local apropriado para se viver: "A Lu é comadre da Nice. Aqui tem moças que casaram com rapazes, então tem gente aqui dentro que constituíram outra família aqui dentro."

Contraditoriamente, se observadas isoladamente as condições de acessibilidade, disponibilidade de serviços públicos e privados e condições de infra-estrutura urbana em geral (ver figura abaixo), o Cingapura Imigrantes estaria em uma condição obviamente muito mais privilegiada do que o Mutirão Campanha Gaúcha. No entanto, os depoimentos indicam exatamente o contrário na percepção dos moradores dos dois conjuntos. 

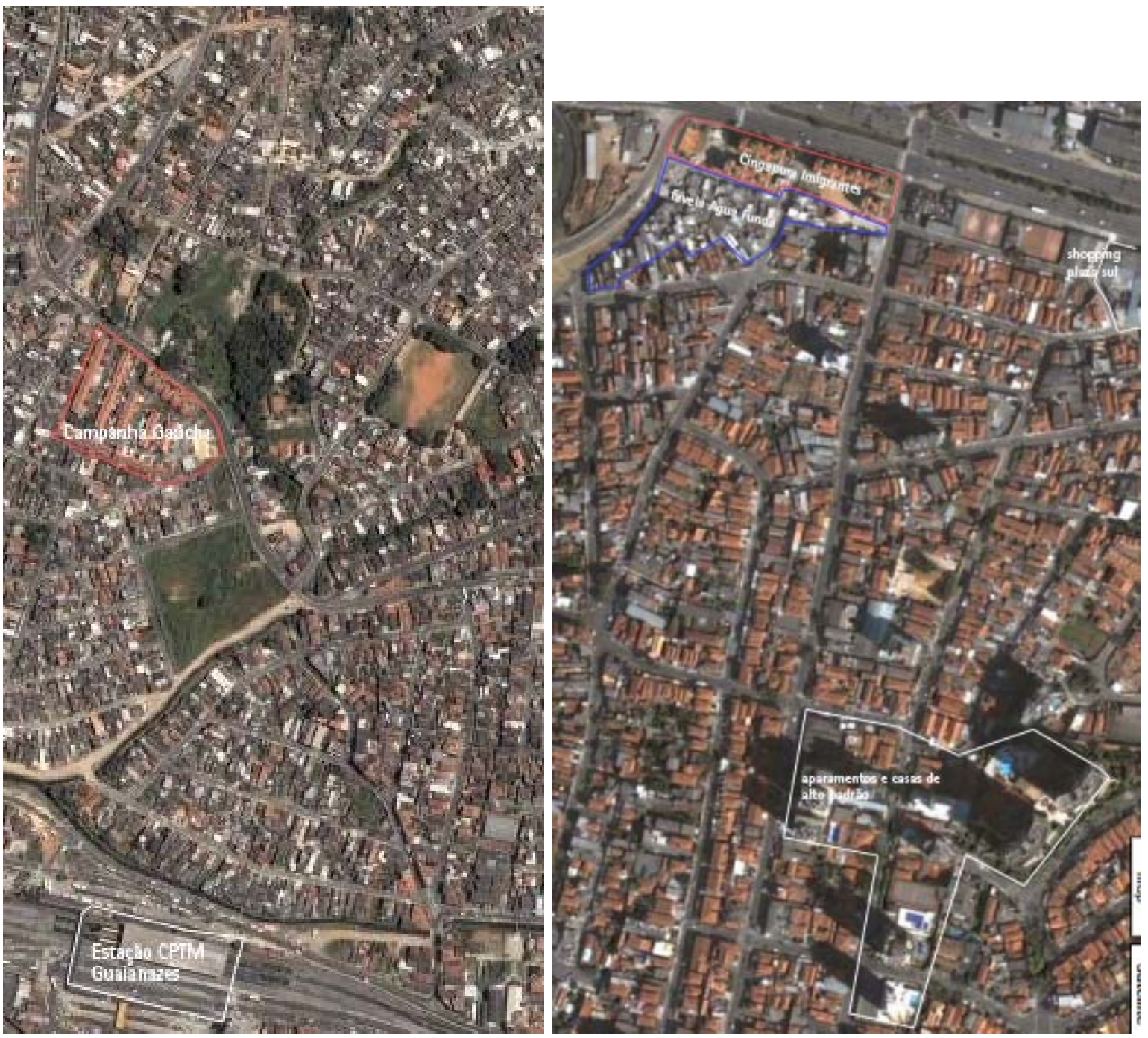

Figura 77 - Inserção Urbana dos Conjuntos

\subsubsection{Quanto às expectativas, iniciativas e participação social}

É nesse ponto que se acentuam as diferenças entre os depoimentos dos empreendimentos estudados.

Enquanto no Campanha Gaúcha o futuro é relatado dentro de um horizonte de lutas

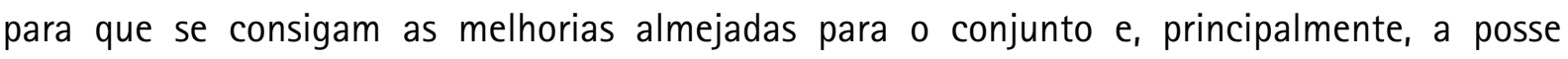
definitiva das casas, no Cingapura Imigrantes o que notadamente as pessoas esperam é obter condições de um dia sair daquele lugar.

A dificuldade de mobilização da população no sentido de se conseguir melhorias para o conjunto é notória no Cingapura Imigrantes. Soma-se a esse fato, a dificuldade imposta pelo domínio do tráfico de drogas no conjunto.

Dessa forma, a resolução dos problemas do conjunto fica exclusivamente a mercê do poder público municipal. Por outro lado, as intervenções promovidas pela prefeitura nesses doze 
anos de ocupação não se mostraram eficazes na solução dos problemas, dada a situação visivelmente precária em que o conjunto se encontra.

Apesar de compartilhar os mesmos problemas da população moradora da Favela da Água Funda, situada ao lado do conjunto, não foi promovido, por nenhuma das partes, algum tipo de organização que defendesse coletivamente os direitos de ambos. Isso pode ser entendido como uma descrença generalizada nos potenciais de transformação a partir da organização coletiva.

No Mutirão Campanha Gaúcha, ocorre uma situação bem diferente da citada acima. Os moradores mantêm a organização coletiva na forma da figura jurídica da Associação dos Moradores do Conjunto Habitacional Campanha Gaúcha. As reuniões são realizadas em uma periodicidade definida há mais de 15 anos, fato que, por si, denota uma consciência coletiva da necessidade de participação na associação.

Ainda com relação ao Campanha Gaúcha, a coerência observada nos depoimentos - ao se relatar os problemas e expectativas para solucioná-los - denota o amadurecimento das práticas coletivas naquela população. Segundo os moradores, isso só foi possível graças ao processo do qual eles participaram para a obtenção da moradia: "foram seis anos de aula minha filha, antes deu entrar aqui."

Se, no caso do Cingapura Imigrantes, a demanda atual é conseguir formar alguma representatividade coletiva dos moradores, no Campanha Gaúcha, o propósito é manter essa representatividade, dado que a desmotivação começa a aparecer pela falta resultados positivos, principalmente com relação a documentação legal das casas.

Com todas as limitações enfrentadas pelos dois conjuntos, percebe-se uma diferença clara na postura dos entrevistados nos dois casos estudados, no que diz respeito as expectativas para o futuro.

No caso do Campanha Gaúcha, a intenção de promover melhorias no conjunto é uma vontade coletiva. Têm-se expectativas de melhorias inclusive com relação ao bairro, através da inserção de novos programas públicos que sirvam à comunidade vizinha, considerada mais carente do que a moradora do conjunto. A articulação da Associação de Moradores do Conjunto Habitacional Campanha Gaúcha com outras associações através do Fórum de Mutirões é entendida pelos moradores como uma conseqüência do processo de amadurecimento que a organização vem desenvolvendo.

Já no Cingapura Imigrantes, as tentativas de formação de uma associação foram fragmentadas pela falta de participação dos moradores. Prevalece a iniciativa individual para a solução dos problemas e a expectativa para o futuro é um dia poder melhorar de vida para sair do conjunto. Os problemas que de alguma forma demandam a organização coletiva, como é o caso do condomínio, as contas de água, luz e manutenção dos espaços comuns, ou ficam sem solução, ou sob responsabilidade de poucos ou ainda na dependência da prefeitura. 
Essa diferença de postura torna evidente o maior equilibrio, tanto psicológico, como social, dos moradores do Campanha Gaúcha no que se refere à capacidade de resolver os próprios problemas, ao passo que o contrário também é notório nos moradores do Cingapura Imigrantes.

\subsubsection{Quanto à participação no processo de produção da moradia}

A intenção de investigar a opinião dos moradores em relação ao propósito de participação nos programas habitacionais foi principalmente verificar o entendimento dos entrevistados acerca desse processo.

Nesse sentido, no caso do Cingapura Imigrantes, os entrevistados demonstraram entender o propósito de participar no processo de produção da moradia apenas como uma possibilidade de resolver questões pontuais. Tal fato pode ser relacionado com a opinião de que as causas dos problemas enfrentados pelo condomínio devem-se, em primeiro lugar, a um equívoco da prefeitura na escolha dos moradores que ocupariam o conjunto.

A postura paternalista do programa é vista como legítima pelos moradores, já que esta apareceu em contraposição ao caos da favela e dada à incapacidade atribuída aos próprios moradores de resolver seus problemas coletivamente.

Nota-se que o processo pelo qual esses moradores foram submetidos até chegar a atual situação de moradia, serviu para reforçar uma postura individualista em detrimento a coletiva. Em nenhum momento foi cogitado que, se a comunidade moradora da favela tivesse participado nesse processo, o resultado poderia ter sido diferente.

No caso dos entrevistados do Campanha Gaúcha, a percepção do processo pelo qual eles passaram até a situação atual de moradia levou a um entendimento muito mais amplo da questão da provisão habitacional por intermédio do Poder Público. Assim como o ocorrido com relação à trajetória habitacional, em que os entrevistados demonstraram alto grau de percepção e consciência do processo, os moradores do Campanha Gaúcha são cientes das práticas e artifícios utilizados pelos mais diversos programas habitacionais e, principalmente, dos direitos do cidadão com relação a habitação. Exemplo disto foi a discussão estabelecida a respeito de outros programas habitacionais.

Porém, apesar da consciência das possibilidades da participação ativa dos futuros moradores na produção de suas casas, os entrevistados relataram que a postura política dos governos municipais desde o fim do FUNAPS Comunitário em muito dificulta a continuidade dos processos autogestionários.

Nota-se que nos dois casos, as diferentes práticas adotadas nos programas produziram níveis de consciência coletiva e até mesmo de percepção da realidade muito distintos.

\subsection{Discussão dos resultados da pesquisa quantitativa.}


Os resultados obtidos com a aplicação do questionário foram extremamente reveladores, ainda que consideradas todas as dificuldades em aplicá-lo relatadas no capítulo 3 deste trabalho.

A reação das pessoas ao questionário foi diferente nos dois conjuntos estudados. No Cingapura Imigrantes, causou estranheza o fato de muitas questões concernentes ao sentimento das pessoas: "Você tem certeza que isso tá certo? Fica perguntando como eu me sinto..." No Campanha Gaúcha, a reação ao questionário foi positiva: "Muito bom mesmo esse questionário, mas minha vida não se resume nas duas últimas semanas..."

A seguir serão discutidos comparativamente os resultados das questões consideradas de maior interesse ao objetivo desse trabalho. Os resultados do questionário serão discutidos dentro dos cinco domínios estabelecidos: físico, psicológico, social, ambiental e geral, cujas pontuações estão sintetizadas no gráfico abaixo.
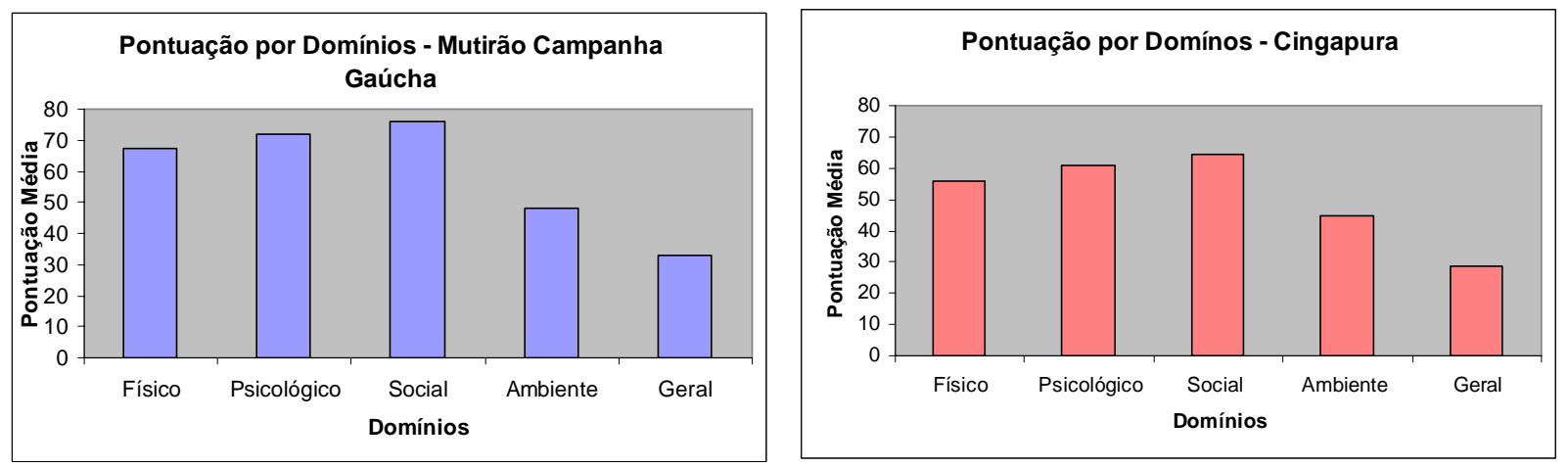

Figura 78 - Gráficos de Pontuação nos Domínios da Pesquisa Quantitativa

As duas primeiras questões, que correspondem ao domínio geral, inferiram sobre a percepção do indivíduo sob sua situação global, física e social.

Observa-se que, enquanto no Cingapura Imigrantes existe uma tendência em avaliar negativamente as atuais condições de vida, tanto físicas como sociais, com 12,5\% dos entrevistados achando que a sua qualidade de vida é ruim, no Campanha Gaúcha essa tendência é invertida, 10\% dos entrevistados acham que sua vida é muito boa.

Dentro da definição da OMS para qualidade de vida: "é a percepção do indivíduo de sua posição na vida no contexto da cultura e sistemas de valores nos quais ele vive e em relação aos seus objetivos, expectativas, padrões e preocupações." Pode-se dizer que, no caso do Cingapura, há uma situação muito precária de sobrevivência humana, condicionada por fatores que vão além dos relacionados à moradia, embora as médias desse domínio não sejam tão discrepantes entre si, fato que pode ser atribuído à heterogeneidade da amostra observada no caso do Cingapura Imigrantes.

A falta de homogeneidade nos resultados do Cingapura Imigrantes também pode ser entendida como uma dificuldade de percepção do indivíduo sobre si mesmo. 
Sem dados mais precisos, não se pode afirmar com exatidão que os dois grupos pesquisados partiram de uma situação inicial idêntica. No entanto, pode-se supor, pelos resultados aqui apresentados, que eles chegaram a distintas percepções em relação às suas condições de vida.

0 domínio físico abrangeu as questões $3,4,10,15,16,17$ e 18 , todas relativas a dor e desconforto, energia e fadiga, sono e repouso, mobilidade, atividades da vida cotidiana, dependência de medicação ou de tratamentos e capacidade de trabalho.

Observando os resultados apresentados para a questão 3, pode-se considerar que não há diferença na percepção entre os dois grupos em relação à saúde física. Portanto, podemos considerar também uma certa homogeneidade das duas amostras, em relação à saúde física.

Porém, ao se analisar a questão 17, que se refere à satisfação pessoal com a capacidade de desempenhar as funções cotidianas, o impressionante valor de 50\% de ruim ou muito ruim no Cingapura Imigrantes e nenhum ruim ou muito ruim no Mutirão Campanha Gaúcha suscitam algumas questões. Como podemos ter uma saúde física equivalente, porém com uma discrepância tão grande na percepção da capacidade individual em desempenhar funções do cotidiano? Talvez a pergunta tenha sido mal entendida, porém os aspectos psicológicos e sociais talvez nos dêem mais respostas.

É no domínio físico onde se observa a maior discrepância entre a pontuação das médias, com o Campanha Gaúcha 12 pontos acima.

Existe uma crescente tendência no meio acadêmico em se relacionar o ambiente com a saúde $^{2}$. Ambiente, conceituado como território vivo, segundo Milton Santos (2001), seria todo lugar em que as relações dos homens e a natureza se dão, sejam elas familiares, de trabalho, lazer, educação, que podem ser favoráveis ou nocivos à saúde.

0 domínio ambiental, abrange o maior número de questões $-8,9,12,13,14,23$, 24 e 25 - relativas a segurança física, proteção, ambiente no lar, recursos financeiros, cuidados de saúde, novas informações e habilidades, recreação e lazer, ambiente físico e transporte.

Curiosamente, é nesse domínio onde se observa a menor diferença entre as médias dos dois conjuntos, com o Campanha Gaúcha apenas 3 pontos acima. Algumas questões relativas a esse domínio apontam os caminhos para se discutir esse fato.

Na questão 9, que avalia a percepção do indivíduo em relação ao ambiente físico, incluindo o local de moradia, no Mutirão Campanha Gaúcha, todas avaliações se situaram entre o mais ou menos, ou o muito pouco, enquanto no Cingapura Imigrantes há uma proporção maior de muito pouco, porém aparece a avaliação bastante.

\footnotetext{
${ }^{2}$ Sobre esse assunto ver especialmente: MALZYNER, 2002; onde o autor investiga as condições de moradia, meio ambiente e saúde de seis conjuntos construídos pelo sistema de autogestão.
} 
Se for comparado o resultado desta questão com o da questão 14, que avalia a percepção do indivíduo em relação às oportunidades de lazer, onde $50 \%$ dos moradores do Cingapura referem como nada e $25 \%$ como muito pouco, enquanto que no Mutirão Campanha Gaúcha tem-se 10\% como nada e 60\% como muito pouco, nota-se que há uma discrepância entre os dois resultados.

A dificuldade de percepção do indivíduo em relação ao meio em que vive e a falta de consciência das suas reais condições de vida pode ser um caminho para explicação desta incoerência. Como visto, o mutirão não foi apenas uma construção de casa, mas uma construção de valores e consciência comunitários.

Ainda dentro do domínio ambiental, uma outra questão de resultado impressionante é a questão 12, que avalia a percepção do indivíduo acerca da disponibilidade de dinheiro para satisfação das necessidades subjetivas de cada um. No Cingapura Imigrantes, 50\% das pessoas avaliam como nada, ou seja, nenhum dinheiro para suas necessidades e outros 50\% como muito pouco, enquanto que no Mutirão Campanha Gaúcha a proporção de nada é de 10\% e 30\% tem algum dinheiro (médio) para suas necessidades.

Seria muito interessante comparar esses dados com o nivel de renda dos moradores, mas, infelizmente, esse levantamento não foi possivel no escopo deste trabalho. Essa comparação permitiria verificar até que ponto a inserção do conjunto na cidade, ou seja, o acesso a shopping centers, grandes supermercados, cinemas, restaurantes e outros serviços que exigem um relativo poder de consumo, influenciam na percepção das necessidades subjetivas do indivíduo.

$\mathrm{Na}$ falta desses dados, o que se pode inferir com os resultados dessa questão é que os moradores do Campanha Gaúcha se sentem muito mais satisfeitos ou realizados dentro das suas expectativas de consumo, em comparação aos do Cingapura Imigrantes, o que certamente contribuiu para uma avaliação positiva das condições atuais de vida, como analisado pelas questões do domínio geral.

0 domínio psicológico é composto pelas questões 5, 6, 7, 11, 19 e 26, relativas a sentimentos positivos, pensar, aprender, memória e concentração, auto-estima, imagem corporal e aparência, sentimentos negativos e espiritualidade/religião/crenças pessoais. Nesse domínio a diferença da pontuação das médias foi alta, com o Campanha Gaúcha 11 pontos acima do Cingapura Imigrantes.

Dentro desse domínio, uma questão muito interessante é a sexta: Em que medida você acha que a sua vida tem sentido? Os resultados obtidos foram extremamente significantes. No Campanha Gaúcha, 100\% das pessoas avaliaram como sua vida tendo bastante sentido ou extremamente. Já no Cingapura Imigrantes, tem-se o impressionante número de $37,5 \%$ de avaliações como nada ou pouco e $25 \%$ de indiferentes. 
A saúde psicológica, segundo Bock (1997), é vista como um conjunto de condições apresentadas pelo indivíduo que lhe permitem a adaptação ao meio social e físico. São características do seu comportamento ou do seu mundo psíquico que lhe permitem comportarse e estar no mundo de forma adaptada. Enfim, é conjunto de fatores que perpassam por questões como autoconfiança, abertura para experiências, criticidade, compreensão, capacidade de amar e trabalhar, sentimento de utilidade, autonomia para ser feliz, exercício de cidadania, equilibrio, adaptação ao meio e ajustamento.

Em face dessa percepção de saúde psicológica, pode-se considerar que os resultados apurados para o Cingapura Imigrantes denotam condições de vida extremamente danosas para o desenvolvimento psicológico do indivíduo.

0 domínio social é composto pelas questões 20, 21 e 22, relativas às relações pessoais, suporte (apoio) social e atividade sexual. Nesse domínio, assim como no psicológico, a diferença da pontuação das médias foi alta, com o Campanha Gaúcha também 11 pontos acima do Cingapura Imigrantes.

Nas questões 20 e 22 que tratam respectivamente da satisfação do indivíduo em relação a suas relações pessoais e do apoio que recebe dos amigos, os dois conjuntos não apresentam diferenças significativas. Esse fato pode estar relacionado com a importância que assumiram as relações pessoais, principalmente quando se tem uma ausência de amparo do Estado, para a estabilização social do indivíduo, discutida no primeiro capítulo deste trabalho. Tanto na favela, como nas habitações autocontruídas, o apoio de amigos e parentes sempre foi decisivo para a sobrevivência da população de baixa renda, em uma cidade excludente como São Paulo.

0 fato curioso é que a questão decisiva nesse domínio foi a 21 , relativa à satisfação sexual do pesquisado, cujo resultado foi $80 \%$ de satisfeitos e muito satisfeitos no Campanha Gaúcha, enquanto que no Cingapura Imigrantes houve uma proporção de 50\% muito insatisfeito, insatisfeito ou indiferente.

A seguir é apresentado um comparativo da pontuação das médias por domínios, entre os dois conjuntos estudados. 


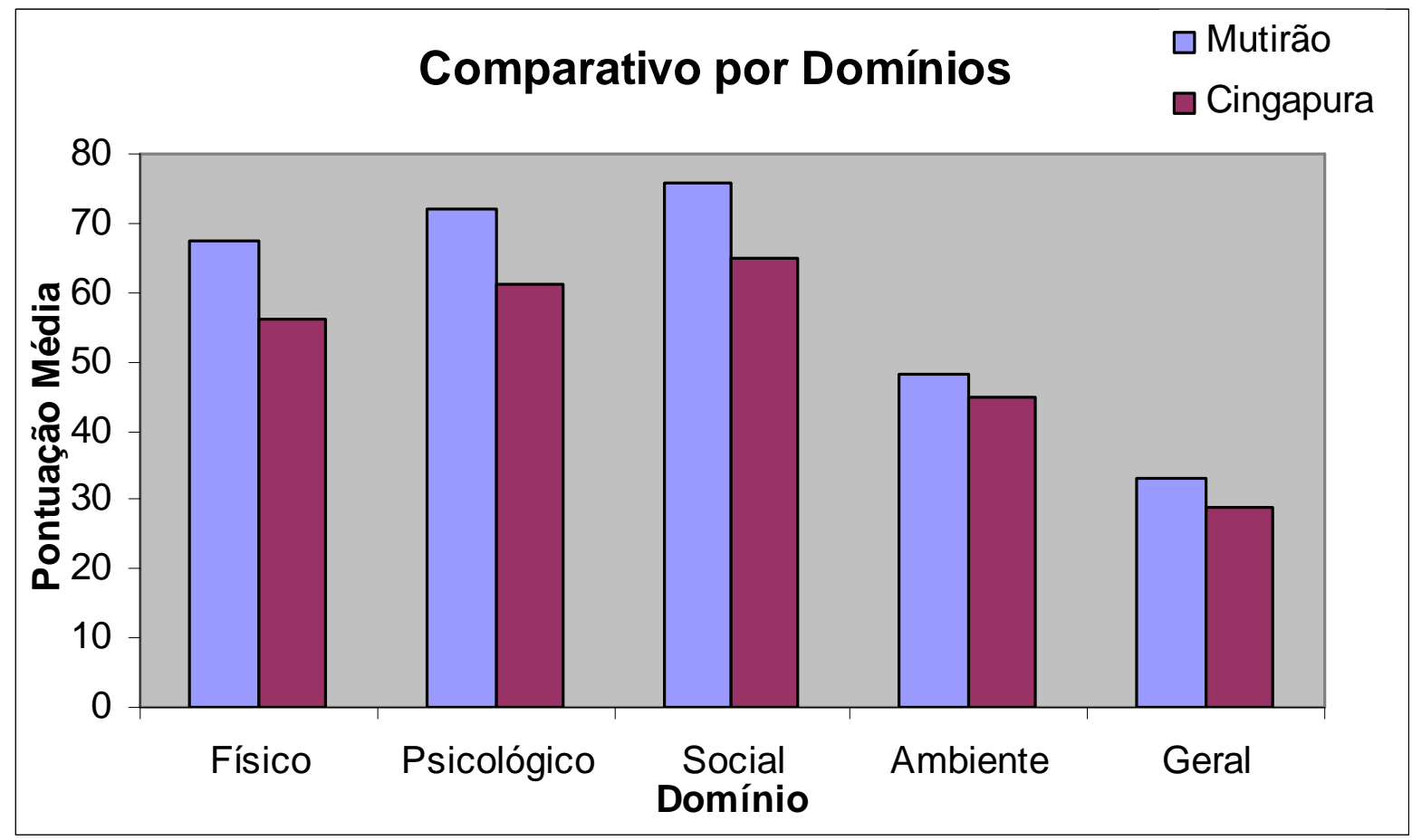

Figura 79 - Gráfico Comparativo por Domínios

Em todos os domínios, o Campanha Gaúcha obteve maior pontuação. De imediato, segundo os objetivos do questionário, pode se considerar que há maior qualidade de vida nesse conjunto, em comparação ao Cingapura Imigrantes, embora as médias não sejam muito discrepantes, fato que pode ser explicado pela heterogeneidade da amostra relativa ao Cingapura Imigrantes.

De forma geral, as pesquisas que, como esta, procuram avaliar programas públicos de habitação, têm como foco as questões ambientais relacionadas à casa, ao conjunto ou até mesmo ao entorno. Analisando o gráfico acima, nota-se que os possíveis ganhos de qualidade de um processo participativo como foi o propiciado pelo FUNAPS Comunitário se situam além das questões ambientais, já que as maiores diferenças são observadas nos domínios físico, psicológico e social.

Assim, tanto mais interessantes e abrangentes serão as análises, quanto maiores forem os domínios abrangido, pois os resultados alcançados pelos dos programas públicos de habitação se mostraram aqui muito maiores do que simplesmente a provisão de moradias.

\subsection{Considerações finais}

Os resultados da investigação desse trabalho, tanto da pesquisa qualitativa, como da quantitativa, corroboraram para a conclusão de que a forma do processo de aquisição de moradia através de programas públicos de habitação altera significativamente o resultado final, sobretudo nos aspectos sociais. 
No caso do FUNAPS Comunitário, esse processo, privilegiou a complexidade de relações sociais da população envolvida. 0 fato desse programa ter direcionado o atendimento à população organizada estimulou a organização coletiva $e_{1}$ conseqüentemente, o desenvolvimento social das pessoas envolvidas.

No caso do Projeto Cingapura, como tratado no escopo desse trabalho, esse processo excluiu a população de todas as decisões envolvidas. 0 pouco envolvimento com o conjunto, as mazelas sociais apontadas e especialmente o baixo grau de consciência e percepção dos indivíduos em relação ao meio em que vivem, são algumas das principais conseqüências desse tipo de postura.

Infelizmente, os programas públicos de HIS têm optado por processos de provisão de moradias pouco ou nada participativos, privilegiando a questão da quantidade, em detrimento da qualidade, com o pretenso propósito de acabar com o déficit habitacional, notadamente sem sucesso. É prática corriqueira que, nas campanhas eleitorais, os feitos em habitação sejam utilizados de forma clientelista e expostos simplesmente em termos de quantidade de unidades habitacionais construídas.

Nessa visão, a eficiência de um programa habitacional seria medida pelo número de unidades construidas no menor espaço de tempo, o que, se baseando pelos resultados expostos nos itens anteriores desse capítulo, empobrece enormemente a questão. Para atingir os objetivos de "inclusão social", termo em voga nas agendas atuais das políticas públicas, os programas de atendimento habitacional precisam balizar sua produção em outros critérios que não somente a capacidade de endividamento da população.

Apesar do modelo de desenvolvimento e crescimento urbano excludente adotado pelo país, do qual a cidade de São Paulo é paradigmática, práticas de organização coletiva, como as instituídas pelo FUNAPS Comunitário, podem constituir um instrumento importante, se não para reverter o quadro de exclusão, para aprimorar a eficiência social dos programas habitacionais.

0 alcance social desses programas cresce à medida em que, através da participação em ações coletivas, os excluídos são capazes de recuperar sua dignidade e conseguem ter autonomia sobre sua própria vida.

Para Paulo Freire (1996), autonomia é a confiança do indivíduo no seu histórico particular, é o desenvolvimento desta confiança, com ações de autodeterminação, de respeito, é o pensar certo, de olhar o mundo buscando sempre o fundamento das coisas, é ter a responsabilidade sobre os seus atos e assumi-los, é ter transparência na fala e coerência nas ações. Para tanto, um ensino com qualidade seria aquele que servisse ao propósito de dar autonomia ao indivíduo, através de um ensino ético, este que apesar das condicionantes desfavoráveis de falta de capacitação profissional, materiais precários e tantas outras, nunca perdesse o foco de formar indivíduos autônomos e responsáveis pelos seus atos. 
As práticas coletivas vivenciadas pelos moradores do Conjunto Habitacional Campanha Gaúcha avançaram na mesma direção da educação proposta por Freire, formando indivíduos mais autônomos e conscientes de sua realidade. Tais práticas também contribuíram para fortalecer as organizações da sociedade civil em torno da questão da moradia, que adquiriram saber e experiência no manejo e na defesa das causas públicas e conquistaram maior confiança na sua capacidade de gerir o próprio destino independente das vontades políticas.

Porém a continuidade deste processo exige o engajamento contínuo do poder público através de políticas voltadas para esse fim, em todos os níveis de governo, o que ainda não ocorreu. Diante da complexidade do desafio de diminuir as desigualdades sociais, da multiplicidade de fatores intervenientes e do crescente déficit habitacional, não se pode esperar por uma solução única e milagrosa.

Para distintas situações sociais, deve haver distintos processos. No caso do Campanha Gaúcha, por exemplo, pode-se dizer que o processo de construção através de mutirão autogerido foi apropriado para uma população já organizada e familiarizada com a idéia. Ao passo que no Cingapura Imigrantes, o processo centralizador adotado, foi estranho às aspirações daquela população. No entanto, não se pode afirmar que em uma população sem vivência e interesse em práticas coletivas, como a do Cingapura Imigrantes, o processo participativo teria conseguido produzir resultados satisfatórios.

As especificidades presentes no cotidiano das pessoas envolvidas pelos programas devem ser levadas em consideração quando da elaboração dos mesmos, pois os ganhos sociais, como visto nesse trabalho, são diretamente proporcionais à percepção de cada indivíduo em relação ao meio em que vive e à sua pontencialidade de transformá-lo. Assim, tanto mais eficientes serão os programas, quanto mais apropriados às expectativas e reais necessidades de seu público. Para isso, tais programas precisam estar em constante processo de reformulação, dada as já comentadas variantes sociais, que mudam acompanhando as mudanças da sociedade.

Assim, a avaliação de resultados dos programas, deve subsidiar o debate dessas reformulações, pois acompanhar esses conjuntos ao longo do tempo é fundamental para transmitir e refletir a dinâmica da criação e recriação permanentes da cultura e seus impactos na formação da personalidade dos membros da sociedade. 0 conhecimento adquirido ao longo desses mais de 70 anos de políticas habitacionais no Brasil, deve imprimir os rumos dos novos programas, ultrapassando as práticas ditadas por interesses políticos escusos. Só assim será possivel desenvolver pensamentos e ações sistêmicas capazes de produzir habitações mais apropriadas para seus usuários. 


\subsection{Limitações da pesquisa e possíveis desdobramentos}

Dentro dos objetivos propostos para essa pesquisa, pode-se dizer que os resultados obtidos cumpriram o propósito de subsidiar a discussão acerca das práticas envolvidas no processo de produção de moradias pelo Poder Público.

Procurou-se comparar dois conjuntos habitacionais, concebidos dentro de duas filosofias diferentes, sem recorrer às formas mais tradicionais de análise, baseadas em características construtivas e ergonômicas. Utilizaram-se as entrevistas com moradores e líderes comunitários e experimentamos uma nova forma de análise, através de um instrumento quantitativo de avaliação da qualidade de vida.

Tem-se consciência de que os dados aqui apresentados não podem e nem devem ser generalizados indiscriminadamente a todos os conjuntos produzidos pelos programas $e_{\text {, ainda }}$ dentro de cada caso analisado, há ainda o erro inerente a uma amostragem não aleatorizada, visto que os questionários foram aplicados às pessoas mais "disponiveis".

Houve também a dificuldade em cruzar os dados da pesquisa quantitativa com indicadores sociais de cada conjunto, devido à falta de previsão de coleta destes no próprio questionário da OMS.

Outra limitação é que não foram encontradas na literatura científica disponível aplicações do citado questionário, com o intuito de comparar dois locais, no mesmo momento temporal, sendo o mesmo mais utilizado como avaliação pré e pós intervenção, idéia interessante para uma próxima pesquisa de campo.

Porém, espera-se que a presente pesquisa traga novos "ares" à avaliação de habitações construídas pelo poder público e como estas influenciam na vida e felicidade das pessoas. 


\section{referências}

AMARAL, Ângela de Arruda Camargo. Habitação na cidade de São Paulo. 2a edição revisada. São Paulo: Pólis / PUCSP, 2002. 120p. (Observatório dos Direitos do Cidadão: acompanhamento e análise das políticas públicas da cidade de São Paulo, 4).

AMARAL, Ângela de Arruda Camargo. Habitação: avaliação da política municipal. Instituto Polis \& PUCSP: São Paulo, 2001.

ANTUNES, Maria Cristina Almeida. A produção habitacional solidária: 0 processo participativo na organização do espaço urbano e na produção da moradia através de procedimentos autogestionários. Tese (Doutorado). Faculdade de Arquitetura e Urbanismo da Universidade de São Paulo, São Paulo, 2002.

AZEVEDO, S. A crise da política habitacional: dilema e perspectivas para o final dos anos 90. in: QUEIROZ RIBEIRO, L. C. e AZEVEDO, S. A crise da moradia nas grandes cidades. Rio de Janeiro: UFRJ, 1996.

AZEVEDO, S. e GAMA DE ANDRADE, L.A. Habitação e Poder. Rio de Janeiro: Zahar, 1982

BAKHTIN, M. Estética da criação verbal. São Paulo: Martins Fontes, 1992

BERLIM, M.T.; FLECK M.P.A. Quality of life: a brand new concept for research and practice in psychiatry. Revista Brasileira de Psiquiatria, 2003; 25(4):249-252.

BERLINCK, M. T.; HOGAN, D. Associações voluntárias, canal de comunicação de massa, informação e adaptação urbana entre as classes populares na cidade de São Paulo, São Paulo, 1971, (mimeo), pág. 13. In: CAMARG0, Cândido Procópio. São Paulo 1975 - Crescimento e Pobreza. São Paulo: Loyola, 1976.

BLAY, Eva A. Eu não tenho onde morar. Vilas operárias na cidade de São Paulo. São Paulo: Nobel, 1985.

BOCK, Ana Mercês Bahia. Quem é o homem na psicologia?. In: Interfaces, Volume 1 JulhoDezembro 97, Número 1.

BONDUKI, Nabil. 0 Estudo da Evolução Urbana de São Paulo. I VALLADARES, Licia P.(org). Repensando a Habitação no Brasil. Rio de Janeiro: Zahar, 1983.

BONDUKI, Nabil. Origens da Habitação Social no Brasil (1930-1945): o caso de São Paulo. Tese (Doutorado). Faculdade de Arquitetura e Urbanismo da Universidade de São Paulo, São Paulo, 1994.

BOTELHO, Ester Zita Fenley. População de baixa renda, Problema Habitacional e Participação: um estudo Psicossocial. Dissertação (Mestrado). Instituto de Psicologia da Universidade de São Paulo, São Paulo, 1982.

BRANDÃO Lopes, Juarez; GOTTSCHALK, Andrea. Recessão, Familia e Pobreza: a década mais do que perdida. São Paulo em Perspectiva. Vol. 4, n.1, jan./mar. 1990.

BUARQUE, Paulo Emílio. Mutirão e Autogestão em São Paulo - Habitação Popular na Gestão Erundina. Cadernos de Pesquisa do LAP no. 27, set-out 98. 
CACCIA BAVA, Silvio. A crise da moradia popular em São Paulo (mimeo). São Paulo: Polis, 1988.

CAMARG0, Cândido Procópio. São Paulo 1975 - Crescimento e Pobreza. São Paulo: Loyola, 1976

CARDOSO, F. H. Considerações sobre o desenvolvimento de São Paulo: cultura e participação. São Paulo: CEBRAP, 1973.

CRUZ, P.D. Notas sobre o endividamento externo brasileiro nos anos Sessenta. In: BELLUZZO, L.G.M.; COUTINHO, R. Desenvolvimento capitalista no Brasil. São Paulo: Brasiliense, 1983. v. 2.

DOIM0, Ana Maria. A voz e a vez do popular: movimentos sociais e participação política no Brasil pós-70. Rio de Janeiro: Relume Dumará, 1989

FLECK M.P.A. et al. Aplicação da versão em português do instrumento WHO0OL-bref. Revista de Saúde Pública 2000;34(2):178-83.

FLECK M.P.A. et al. Desenvolvimento da versão em português do instrumento de avaliação de qualidade de vida da Organização Mundial da Saúde (WHOQOL-100) 1999. Revista Brasileira de Psiquiatria 1999;21(1):19-28.

FORATO, Sylvia; RIBEIRO, Wagner Costa. Habitação em São Paulo e Financiamento Externo. Scripta Nova REVISTA ELECTRÓNICA DE GEOGRAFÍA Y CIENCIAS SOCIALES. Universidad de Barcelona. Vol. VII, n. 146(097), 1 de agosto de 2003.

FREIRE, Paulo. Pedagogia da Autonomia - Saberes Necessários à Prática Educativa. São Paulo: Paz e Terra, 1996

FREITAS, Maria Teresa de Assunção. A abordagem sócio-histórica como orientadora da pesquisa qualitativa. Cad. Pesqui., Julho 2002, no.116, p.21-39

GODINHO, M. T. Metropolização e planejamento social. São Paulo: PUC, 1974, 2 v.

GOHN, Maria da Glória. Movimentos de luta pela moradia. São Paulo: Editora Loyola, 1991

GROSTEIN, Marta Dora. Metrópole e Expansão Urbana: a persistência de processos "insustentáveis". São Paulo, Perspec. vol.15 no.1 São Paulo Jan./Mar. 2001.

GWATKIN, D. R. Indications of change in developing country mortality trends : the end of an era? Population and Development Review, New York, v. 6, n. 4, p. 615-644, Dec.1980 e PALLONI, Alberto. Mortality in Latin America: emerging patterns. Population and Development Review, New York, v. 7, n. 4, p. 623-649, Dec. 1981.

IBGE. Evolução e perspectivas da mortalidade infantil no Brasil. Rio de Janeiro: IBGE, Departamento da População e Indicadores Sociais, 1999.

KOWARICK, Lúcio. Escritos Urbanos. São Paulo: Editora 34, 2000.

KRAHENBUHL, Lair A. S. Cingapura - 0 Encontro de São Paulo com a Cidadania. São Paulo: Bix Design Corporativo, 1996.

LÉVI-STRAUSS, Claude. Tristes Trópicos. São Paulo: Companhia das Letras, 1996.

LIMA, Maria Helena Beozzo de. Em busca da casa própria: autoconstrução na periferia do Rio de Janeiro. In: VALLADARES, L.P. (org). Habitação em questão. Rio de Janeiro: Zahar, 1981.

MALZYNER, Carlos. Habitação, meio ambiente e saúde: diagnóstico de necessidades dos mutirantes da cidade de São Paulo - Região Leste I. Tese (Doutorado), Faculdade de Saúde Pública da Universidade de São Paulo, São Paulo, 2002. 
MARICATO, Ermínia. Metrópole na periferia do capitalismo. Ilegalidade, desigualdade e violência. São Paulo: Hucitec, 1996.

OLIVEIRA, Francisco de. A Economia brasileira: crítica à razão dualista. São Paulo: Estudos CEBRAP, 1972.

OMETTO, Ana Maria H. et al. The Brazilian economy of the 80's and its impact on the living conditions of the population. Revista de Saúde Pública, oct. 1995, vol.29, no.5.

PMSP - SEMPLA. São Paulo: crise e mudança. São Paulo: Brasiliense, 1990.

PMSP-COBES. Favelas no município de São Paulo. São Paulo, PMSP, 1980.

PMSP-SEBES-HABI-COPED. Estudo sobre o fenômeno favela no município de S. Paulo. São Paulo, PMSP, s.d.

PMSP-SEHAB. Relatório de gestão 1989-1992 da Secretaria de Habitação e Desenvolvimento da Prefeitura do Município de São Paulo. São Paulo, PMSP, 1992.

PMSP-SEHAB-HABI. Censo das favelas do município de São Paulo. São Paulo, PMSP, 1987.

RONCONI, REGINALDO L. N. Habitações construídas com gerenciamento pelos usuários, com organização da força de trabalho em regime de mutirão: o programa FUNAPS comunitário. Dissertação (Mestrado). Escola de Engenharia de São Carlos - USP, São Carlos, 1995.

ROSSETO, Rossella. Fundo Municipal de Habitação. São Paulo: POLIS/PUC-SP, 2003.

SACHS, Céline. São Paulo Políticas Públicas e Habitação Popular. São Paulo: Edusp, 1999.

SANTOS, C.N.F. dos. Movimentos Urbanos no Rio de Janeiro. Rio de Janeiro: Zahar, 1981.

SANTOS, Milton; SILVEIRA, Maria Laura. Brasil: Território e Sociedade no Início do Século XXI. São Paulo: Record, 2001.

SILVA, Vanildo Luis. Cingapura: a Espacialidade do Programa Habitacional do Município de São Paulo na Década de 90 do Século XX. Dissertação (Mestrado). Faculdade de Filosofia, Letras e Ciências Humanas - Departamento de Geografia, USP, São Paulo, 2003.

SZMRECSANYI, Maria Irene de O. F. (org). Cotidiano, Cultura Popular e Planejamento Urbano. São Paulo: FAU/USP, 1985.

TASCHNER, Suzana P. Política Habitacional no Brasil: Retrospectiva e Perspectiva. São Paulo, Cadernos de Pesquisa do LAP USP/FAU, set - out 1997.

TASCHNER, Suzana P.; MAUTNER, Yvone. Alternativas Habitacionais para a população de baixa renda. São Paulo: FAU-USP, s.d. (mimeo).

TASCHNER, SUZANA P; BOGUS, LUCIA M. M. São Paulo: 0 Caleidoscópio Urbano. São Paulo em Perspectiva, Jan./Mar. 2001, vol.15, no.1.

The WHOQOL Group. Development of the World Health Organization WHOQOL-BREF Quality of Life Assesment 1998. Psychol Med 1998;28:551-8.

The WHOQOL Group. The development of the World Health Organization quality of life assessment instrument (the WHOOOL). In: Orley J, Kuyken W, editors. Quality of life assessment: international perspectives. Heidelberg: Springer Verlag; 1994. p 41-60.

UGÁ, Maria Alícia D.Crise econômica e políticas sociais: elementos para discussão Cadernos de Saúde Pública v.5 n.3 Rio de Janeiro jul./set. 1989.

UMM. Carta encaminhada pela União dos Movimentos de Moradia ao Secretário Municipal de Habitação. UMM: São Paulo, 03 de setembro de 1993. 
VALLADARES, Lícia Prado (org). Repensando a habitação no Brasil. Rio de Janeiro: Zahar, 1983. 
anexo1

\title{
WHOQOL - ABREVIADO
}

Versão em Português

\author{
PROGRAMA DE SAÚDE MENTAL \\ ORGANIZAÇÃO MUNDIAL DA SAÚDE \\ GENEBRA
}

Coordenação do GRUPO WHOQOL no Brasil

Dr. Marcelo Pio de Almeida Fleck

Professor Adjunto

Departamento de Psiquiatria e Medicina Legal

Universidade Federal do Rio Grande do Sul

Porto Alegre - RS - Brasil 


\section{Instruções}

Este questionário é sobre como você se sente a respeito de sua qualidade de vida, saúde e outras áreas de sua vida. Por favor, responda a todas as questões. Se você não tem certeza sobre que resposta dar em uma questão, por favor, escolha entre as alternativas a que the parece mais apropriada. Esta, muitas vezes, poderá ser sua primeira escolha.

Por favor, tenha em mente seus valores, aspirações, prazeres e preocupações. Nós estamos perguntando o que você acha de sua vida, tomando como referência as duas últimas semanas. Por exemplo, pensando nas últimas duas semanas, uma questão poderia ser:

\begin{tabular}{||l|c|c|c|c|c||}
\hline \hline & nada & $\begin{array}{l}\text { muito } \\
\text { pouco }\end{array}$ & médio & muito & completamente \\
\hline $\begin{array}{l}\text { Você recebe dos outros o apoio de que } \\
\text { necessita? }\end{array}$ & 1 & 2 & 3 & 4 & 5 \\
\hline \hline
\end{tabular}

Você deve circular o número que melhor corresponde ao quanto você recebe dos outros o apoio de que necessita nestas últimas duas semanas. Portanto, você deve circular o número 4 se você recebeu "muito" apoio como abaixo.

\begin{tabular}{||l|c|c|c|c|c||}
\hline \hline & nada & $\begin{array}{c}\text { muito } \\
\text { pouco }\end{array}$ & médio & muito & completamente \\
\hline $\begin{array}{l}\text { Você recebe dos outros o apoio de que } \\
\text { necessita? }\end{array}$ & 1 & 2 & 3 & 4 & 5 \\
\hline \hline
\end{tabular}

Você deve circular o número 1 se você não recebeu "nada" de apoio. 
Por favor, leia cada questão, veja o que você acha e circule no número e the parece a melhor resposta.

\begin{tabular}{|c|c|c|c|c|c|c|c|}
\hline & & & muito & nuim & $\begin{array}{r}\text { nem ruim } \\
\text { nem boa }\end{array}$ & boa & $\begin{array}{l}\text { muito } \\
\text { boa }\end{array}$ \\
\hline \multirow[t]{2}{*}{1} & $\begin{array}{l}\text { Como você avaliaria sua qualidade de } \\
\text { vida? }\end{array}$ & & 1 & 2 & 3 & 4 & 5 \\
\hline & & $\begin{array}{l}\text { muito } \\
\text { insatisfeito }\end{array}$ & insatisfeito & & $\begin{array}{l}\text { nem satisfeito } \\
\text { nem insatisfeito }\end{array}$ & satisfeito & $\begin{array}{c}\text { muito } \\
\text { satisfeit } \\
0\end{array}$ \\
\hline 2 & $\begin{array}{l}\text { Quão satisfeito(a) você está } \\
\text { com a sua saúde? }\end{array}$ & 1 & 2 & & 3 & 4 & 5 \\
\hline
\end{tabular}

As questões seguintes são sobre o quanto você tem sentido algumas coisas nas últimas duas semanas.

\begin{tabular}{|c|c|c|c|c|c|c|}
\hline & & nada & $\begin{array}{l}\text { muito } \\
\text { pouco }\end{array}$ & $\begin{array}{l}\text { mais ou } \\
\text { menos }\end{array}$ & $\begin{array}{l}\text { bastant } \\
\text { e }\end{array}$ & extremamente \\
\hline 3 & $\begin{array}{l}\text { Em que medida você acha que sua dor } \\
\text { (fisica) impede você de fazer o que você } \\
\text { precisa? }\end{array}$ & 1 & 2 & 3 & 4 & 5 \\
\hline 4 & $\begin{array}{l}\text { O quanto você precisa de algum } \\
\text { tratamento médico para levar sua vida } \\
\text { diána? }\end{array}$ & 1 & 2 & 3 & 4 & 5 \\
\hline 5 & O quanto você aproveita a vida? & 1 & 2 & 3 & 4 & 5 \\
\hline 6 & $\begin{array}{l}\text { Em que medida você acha que a sua vida } \\
\text { tem sentido? }\end{array}$ & 1 & 2 & 3 & 4 & 5 \\
\hline 7 & O quanto você consegue se concentrar? & 1 & 2 & 3 & 4 & 5 \\
\hline 8 & $\begin{array}{l}\text { Quão seguro(a) você se sente em sua vida } \\
\text { diána? }\end{array}$ & 1 & 2 & 3 & 4 & 5 \\
\hline 9 & $\begin{array}{l}\text { Quão saudável é o seu ambiente físico } \\
\text { (clima, barulho, poluição, atrativos)? }\end{array}$ & 1 & 2 & 3 & 4 & 5 \\
\hline
\end{tabular}

As questões seguintes perguntam sobre certas coisas nestas últimas duas semanas.

quão completamente você tem sentido ou é capaz de fazer

\begin{tabular}{|c|c|c|c|c|c|c|}
\hline & & nada & $\begin{array}{l}\text { muito } \\
\text { pouco }\end{array}$ & médio & muito & completamente \\
\hline 10 & Você tem energia suficiente para seu dia-a-dia? & 1 & 2 & 3 & 4 & 5 \\
\hline 11 & Você é capaz de aceitar sua aparência fisica? & 1 & 2 & 3 & 4 & 5 \\
\hline 12 & $\begin{array}{l}\text { Você tem dinheiro suficiente para satisfazer suas } \\
\text { necessidades? }\end{array}$ & 1 & 2 & 3 & 4 & 5 \\
\hline 13 & $\begin{array}{l}\text { Quão disponiveis para você estão as } \\
\text { informações que precisa no seu dia-a-dia? }\end{array}$ & 1 & 2 & 3 & 4 & 5 \\
\hline 14 & $\begin{array}{l}\text { Em que medida você tem oportunidades de } \\
\text { atividade de lazer? }\end{array}$ & 1 & 2 & 3 & 4 & 5 \\
\hline
\end{tabular}


As questões seguintes perguntam sobre quão bem ou satisfeito você se sentiu a respeito de vários aspectos de sua vida nas últimas duas semanas.

\begin{tabular}{||l|l|c|c|c|c|c||}
\hline \hline 15 & Quão bem você é capaz de se locomover? & $\begin{array}{c}\text { muito } \\
\text { num }\end{array}$ & num & $\begin{array}{c}\text { nem ruim } \\
\text { nem bom }\end{array}$ & bom & $\begin{array}{c}\text { muito } \\
\text { bom }\end{array}$ \\
\hline
\end{tabular}

\begin{tabular}{|c|c|c|c|c|c|c|}
\hline & & $\begin{array}{c}\text { muzo } \\
\text { insatisfeatio }\end{array}$ & insatisfeito & $\begin{array}{c}\text { Dem stisfexto } \\
\text { Den insaiffeito }\end{array}$ & snisffeito & $\begin{array}{l}\text { muizo } \\
\text { satisfeito }\end{array}$ \\
\hline 16 & $\begin{array}{l}\text { Quão satisfeito(a) você está com o seu } \\
\text { sono? }\end{array}$ & 1 & 2 & 3 & 4 & 5 \\
\hline 17 & $\begin{array}{l}\text { Quão satisfeito(a) você está com sua } \\
\text { capacidade de desempenhar as atividades } \\
\text { do seu dia-a-dia? }\end{array}$ & 1 & 2 & 3 & 4 & 5 \\
\hline 18 & $\begin{array}{l}\text { Quão satisfeito(a) você está com sua } \\
\text { capacidade para o trabalho? }\end{array}$ & 1 & 2 & 3 & 4 & 5 \\
\hline 19 & $\begin{array}{l}\text { Quão satisfeito(a) você está consigo } \\
\text { mesmo? }\end{array}$ & 1 & 2 & 3 & 4 & 5 \\
\hline 20 & $\begin{array}{l}\text { Quão satisfeito(a) você está com suas } \\
\text { relações pessoais (amigos, parentes, } \\
\text { conhecidos, colegas)? }\end{array}$ & 1 & 2 & 3 & 4 & 5 \\
\hline 21 & $\begin{array}{l}\text { Quão satisfeito(a) você está com sua vida } \\
\text { sexual? }\end{array}$ & 1 & 2 & 3 & 4 & 5 \\
\hline 22 & $\begin{array}{l}\text { Quão satisfeito(a) você está com o apoio } \\
\text { que você recebe de seus amigos? }\end{array}$ & 1 & 2 & 3 & 4 & 5 \\
\hline 23 & $\begin{array}{l}\text { Quão satisfeito(a) você está com as } \\
\text { condições do local onde mora? }\end{array}$ & 1 & 2 & 3 & 4 & 5 \\
\hline 24 & $\begin{array}{l}\text { Quão satisfeito(a) você está com o seu } \\
\text { acesso aos serviços de saúde? }\end{array}$ & 1 & 2 & 3 & 4 & 5 \\
\hline 25 & $\begin{array}{l}\text { Quão satisfeito(a) você está com o seu } \\
\text { meio de transporte? }\end{array}$ & 1 & 2 & 3 & 4 & 5 \\
\hline
\end{tabular}

As questões seguintes referem-se a com que freqüência você sentiu ou experimentou certas coisas nas últimas duas semanas.

\begin{tabular}{|c|c|c|c|c|c|c|}
\hline & & maxa & danx & fequetemete & $\begin{array}{l}\text { mudo } \\
\text { fegietemete }\end{array}$ & enpe \\
\hline 26 & $\begin{array}{l}\text { Com que frequêencia você tem } \\
\text { sentimentos negativos tais como mau } \\
\text { humor, desespero, ansiedade, } \\
\text { depressão? }\end{array}$ & 1 & 2 & 3 & 4 & 5 \\
\hline
\end{tabular}

Alguém the ajudou a preencher este questionário?.

Quanto tempo você levou para preencher este questionánio?

Você tem algum comentário sobre o questionário?

OBRIGADO PELA SUA COLABORAÇÃO 


\title{
anexo 2
}

\section{STEPS FOR CHECKI NG AND CLEANI NG DATA AND COMPUTI NG FACET AND DOMAIN SCORES}

\author{
Recode q3 q4 q26 $(1=5)(2=4)(3=3)(4=2)(5=1)$. \\ (scores based on a 4-20 scale) \\ compute dom $1=($ mean. $6(q 3, q 4, q 10, q 15, q 16, q 17, q 18)) * 4$. \\ compute dom $2=(\operatorname{mean} .5(q 5, q 6, q 7, q 11, q 19, q 26)) * 4$ \\ compute dom $3=($ mean. $2(q 20, q 21, q 22)) * 4$ \\ compute dom $4=($ mean.6 $(q 8, q 9, q 12, q 13, q 14, q 23, q 24, q 25)) * 4$ \\ compute overall $=($ mean. $2(q 1, q 2)) * 4$ \\ (scores transformed to a $0-100$ scale) \\ compute dom $1 b=(\operatorname{dom} 1-4) *(100 / 16)$. \\ compute $\operatorname{dom} 2 \mathrm{~b}=(\operatorname{dom} 2-4) *(100 / 16)$. \\ compute dom $3 b=(\operatorname{dom} 3-4) *(100 / 16)$. \\ compute dom $4 b=($ dom $4-4) *(100 / 16)$. \\ compute $q 1 b=(q 1-1) *(100 / 16)$. \\ compute $\mathrm{q} 2 \mathrm{~b}=(\mathrm{q} 2-1) *(100 / 16)$.
}

